\title{
A HMG-KOA REDUKTÁz FUNKCIONÁLIS VIZSGÁLATA MUCOR CIRCINELLOIDES-BEN
}

\section{DOKTORI ÉRTEKEZÉS}

\author{
NAGY GÁBOR
}

\author{
TÉMAVEZETő: \\ DR. PAPP TAMÁS \\ EGYETEMI DOCENS
}

BIOLÓGIA DOKTORI ISKOLA

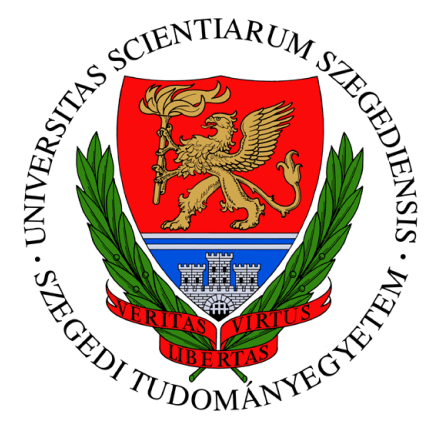

SZEGEDI TUDOMÁNYEGYETEM

TERMÉSZETTUDOMÁNYI ÉS INFORMATIKAI KAR MIKROBIOLÓGIAI TANSZÉK 


\section{TARTALOMJEGYZÉK}

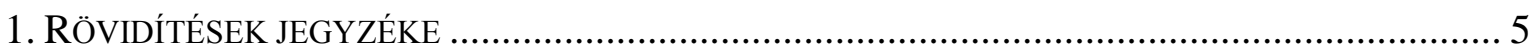

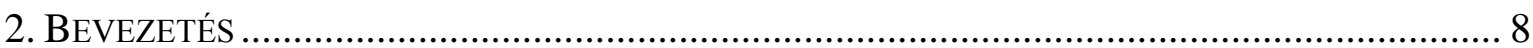

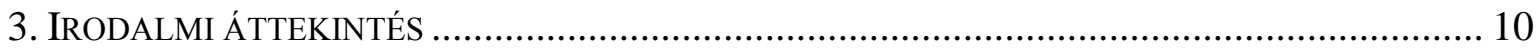

3.1. A Járomspórás gombák (Mucoromycotina) általános jellemzői ............................. 10

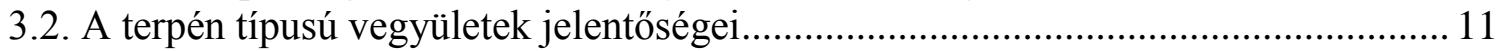

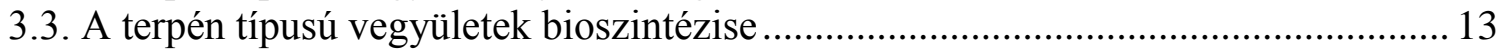

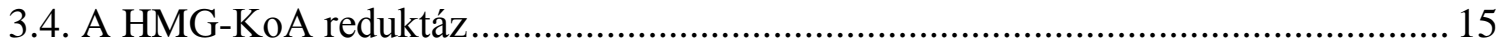

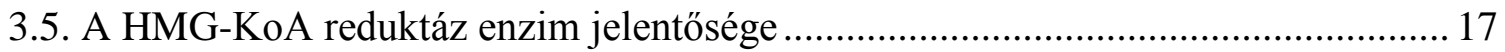

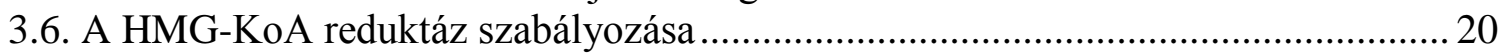

3.6.1. A HMG-KoA reduktáz szabályozása emberben ............................................. 20

3.6.2. A HMG-KoA reduktáz szabályozása gombákban .......................................... 22

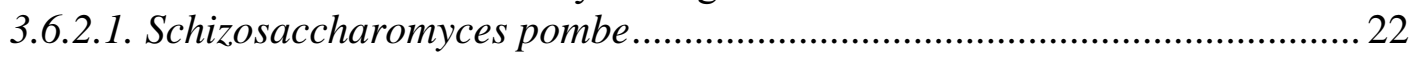

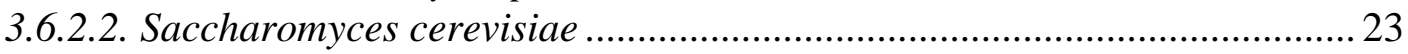

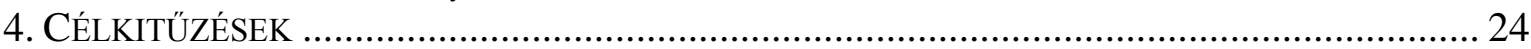

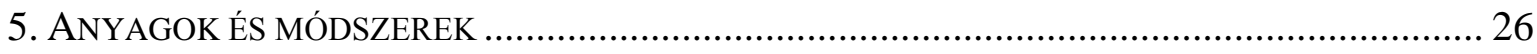

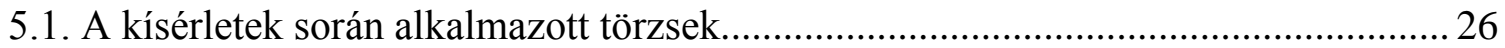

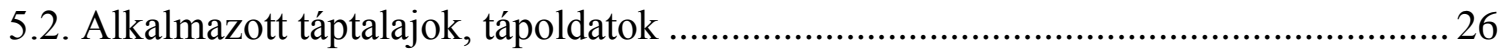

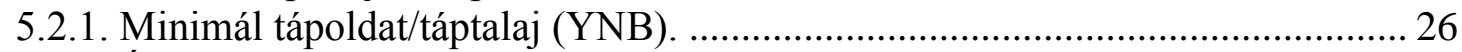

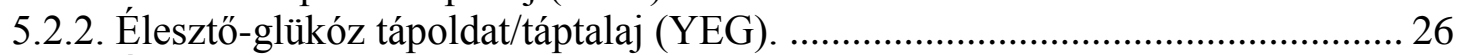

5.2.3. Élesztő-pepton-glükóz tápoldat/táptalaj (YPG). ............................................ 26

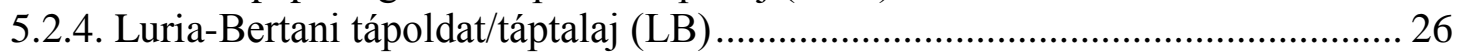

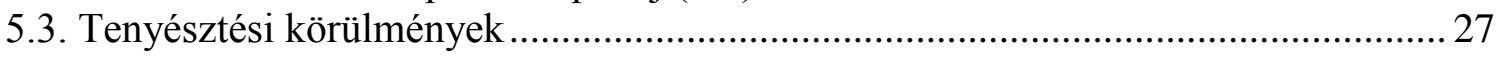

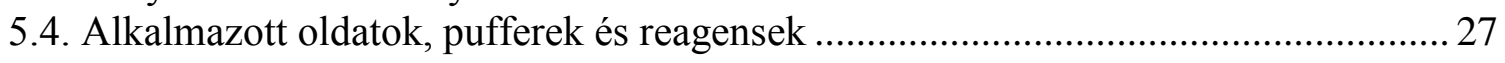

5.4.1. Kompetens E. coli sejtek készítéséhez felhasznált oldatok............................... 27

5.4.2. E. coli sejtek transzformációjához felhasznált oldatok ................................... 27

5.4.3. DNS gélelektroforézishez használt anyagok ................................................ 27

5.4.4. Protoplasztképzéshez és PEG-mediált transzformációhoz használt oldatok..... 27

5.4.5. Northern hibridizáláshoz használt reagensek ............................................. 28

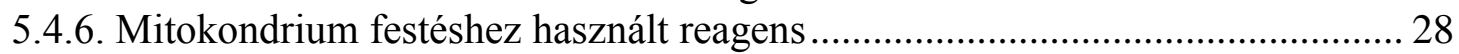

5.4.7. Endoplazmás retikulum festéshez használt reagens ....................................... 29

5.4.8. Apoptózis folyamatainak detektálásához használt reagens ............................. 29

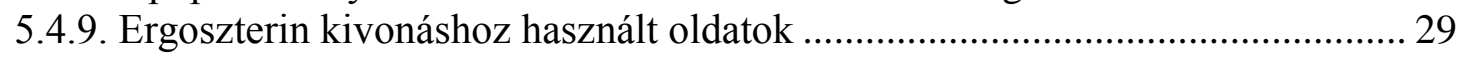

5.4.10. Membránfrakció izolálásához használt oldatok ............................................ 29

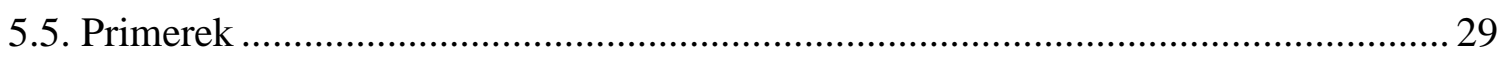

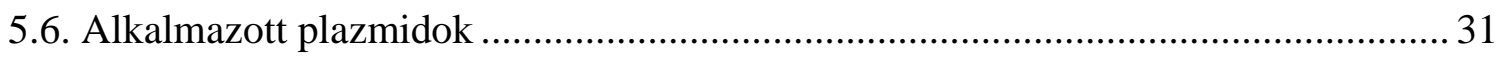

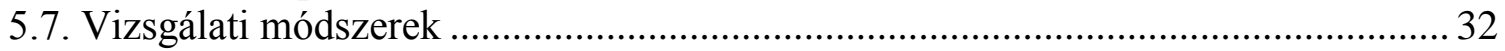

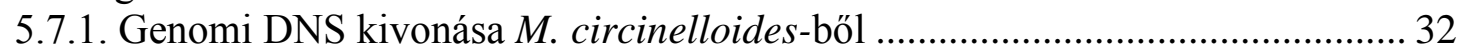

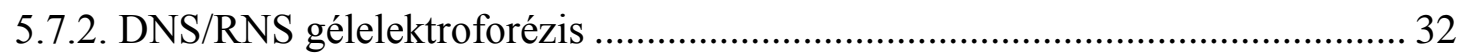

5.7.3. RNS gélelektroforézis Northern hibridizációhoz .......................................... 32

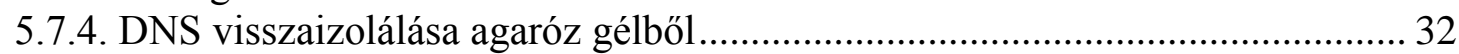

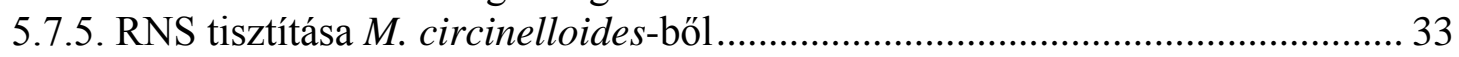

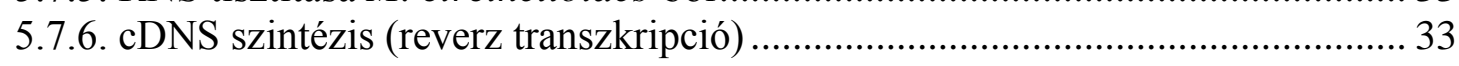

5.7.7. Alkalmazott PCR technikák és reakciókörülmények …….............................. 33

5.7.7.1. A $h m g R$ gének amplifikálásához használt reakciókörülmények ................ 33

5.7.7.2. A $h m g R$ gének cDNS amplifikálásához használt reakció körülmények .... 35

5.7.7.3. A gének csendesítését lehetővé tevő génszakaszok amplifikálásához használt reakciókörülmények ................................................................ 36

5.7.7.4. A jelölt hibridizációs próba készítéséhez használt reakciókörülmények ... 36 
5.7.7.5. A $g f p$ gén amplifikálásához használt reakciókörülmények

5.7.7.6. Valós idejü PCR reakciók a kópiaszám, valamint a transzkripciós szintek meghatározásához

5.7.7.7. A $h m g R$ gének túlmüködtetését lehetővé tevő vektorok kimutatására használt PCR reakció:

5.7.8. Génklónozás során alkalmazott módszerek, plazmidkonstrukciók létrehozása 38

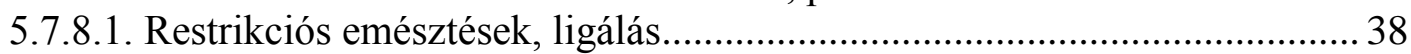

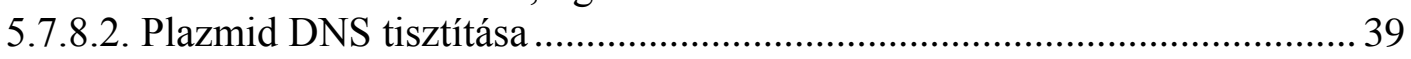

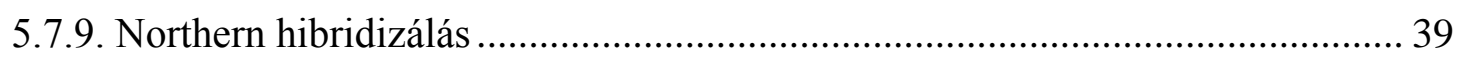

5.7.10. A feltételezett HMG-KoA reduktáz szekvenciák analíziséhez használt

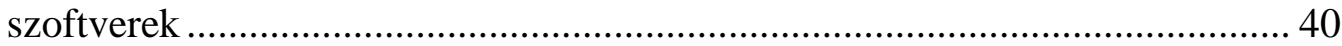

5.7.11. Kompetens E. coli sejtek készítése............................................................... 40

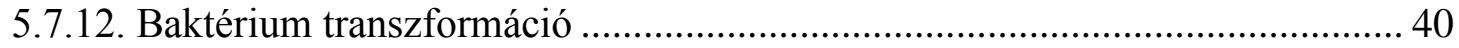

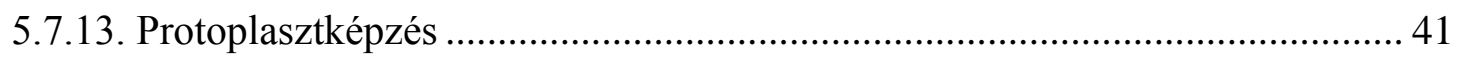

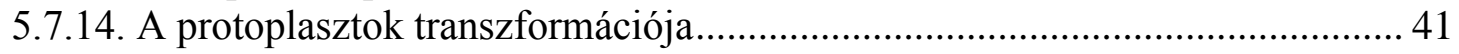

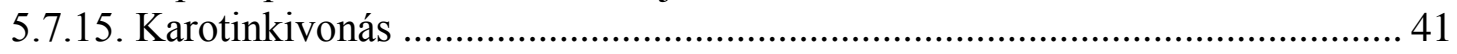

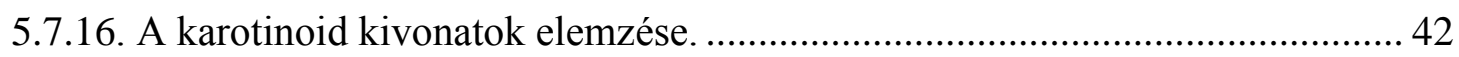

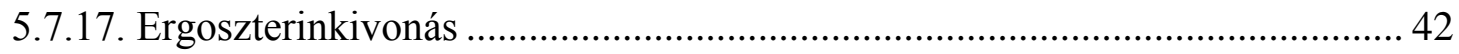

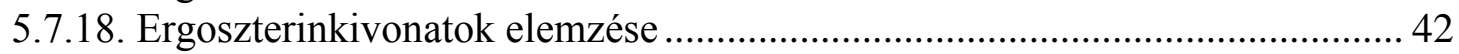

5.7.19. A sztatinok minimális gátló koncentrációjának (MIC érték) meghatározása . 43

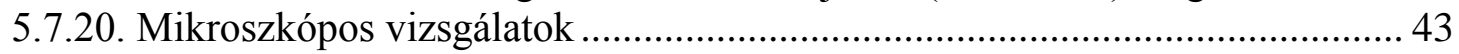

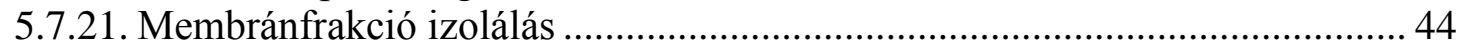

5.7.22. A membránfrakció fluoreszcenciájának vizsgálata ......................................... 44

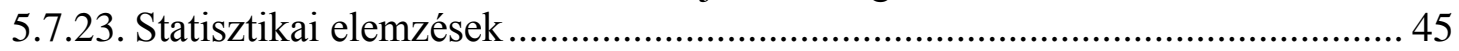

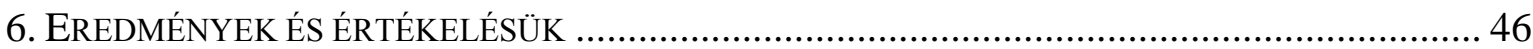

6.1. A Mucor circinelloides 3-hidroxi-3-metilglutaril koenzim A reduktáz génjeinek

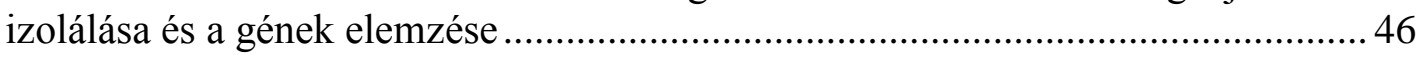

6.2. A $M$. circinelloides HMG-KoA reduktázainak jellemzése ...................................... 47

6.3. Az egyes $h m g R$ gének kifejeződésének vizsgálata különböző tenyésztési

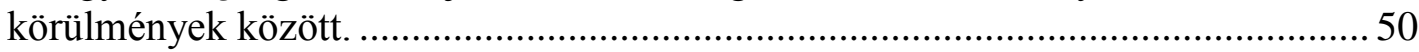

6.3.1. A $h m g R$ gének relatív transzkripciós szintjei a tenyésztési időszak alatt.......... 51

6.3.2. A $h m g R$ gének relatív transzkripciós szintjei különbözö hőmérsékleten.......... 54

6.3.3. Sóstressz hatása a $M u c o r ~ h m g R$ génjeinek relatív transzkripciójára .................. 56

6.3.4. A $h m g R$ gének relatív transzkripciós szintjei különböző szénforrásokon .......... 57

6.3.5. A $h m g R$ gének relatív transzkripciós szintjei aerob és anaerob körülmények

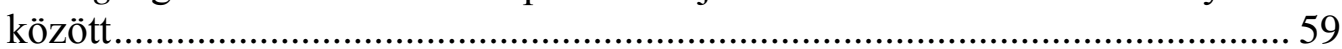

6.3.6. A relatív transzkripciós szint mérések legfontosabb eredményei ..................... 62

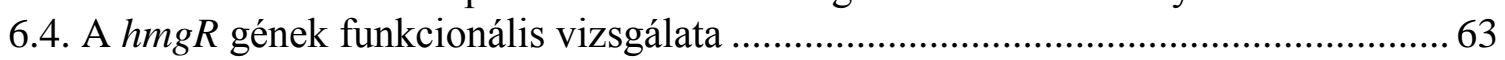

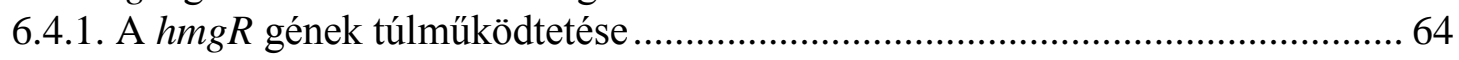

6.4.2. A $h m g R$ gének csendesítését lehetővé tevő vektorkonstrukciók építése........... 65

6.4.3. A mutáns törzsek növekedésének vizsgálata................................................. 67

6.4.4. A $h m g R$ gének túlmüködtetésének és csendesítésének hatása transzformáns

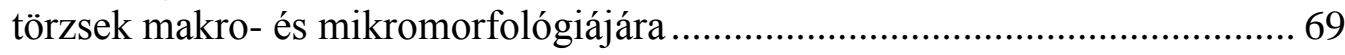

6.4.5. A transzformáns törzsek karotin és ergoszterin tartalmának vizsgálata............ 75

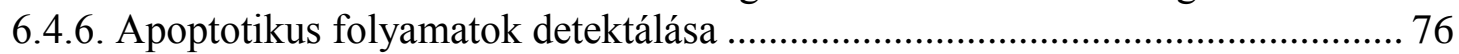

6.4.7. A mutáns törzsek sztatinokkal szembeni érzékenységének vizsgálata ............. 79

6.4.8. A $h m g R$ gének funkcionális vizsgálatának legfontosabb eredményei .............. 81

6.5. A HMG-KoA reduktázok sejten belüli lokalizációjának vizsgálata ......................... 82

6.5.1. A vektor konstrukciókat hordozó transzformánsok vizsgálata ......................... 84 
6.5.2. Kolokalizációs vizsgálatok az endoplazmatikus retikulummal és

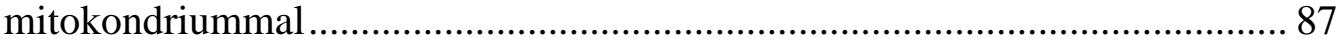

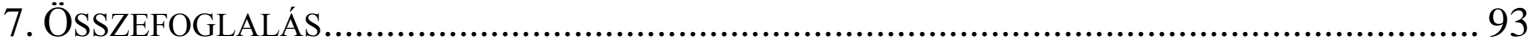

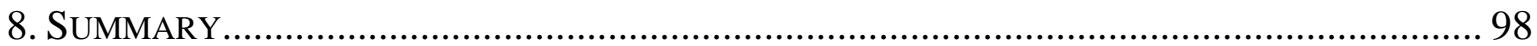

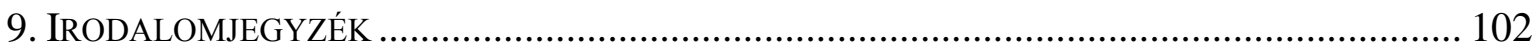

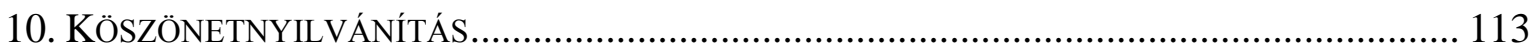

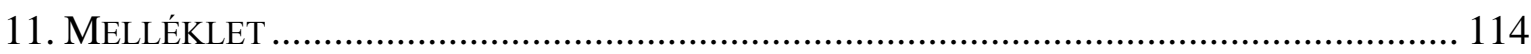




\section{RöVIDÍTÉSEK JEGYZÉKE}

AACT

asRNS

CBS

DMAPP

DEPC

DHA

EDTA

EMBL

ER

ERAD

FPP

GFP

$\mathrm{GGOH}$

GGPP

GPP

HMG-KoA

HMGS

HPLC

HRD

IDI

IPK

IPP

LB

MDC

MEP

MEV

MOPS

MPD
Acetoacetil-koenzim A tioláz

Antiszensz RNS

Centraalbureau voor Schimmelcultures, The Netherlands

Dimetilallil-pirofoszfát

Dietil-pirokarbonát

Dihidroxi-aceton

Etilén-diamin-tetraecetsav

European Molecular Biology Laboratory

Endoplazmatikus retikulum

ER-kapcsolt fehérje degradáció (Endoplasmic-reticulumassociated protein degradation)

Farnezil-pirofoszfát

Zöld fluoreszcens protein (Green Fluorescent Protein)

Geranilgeraniol

Geranilgeranil-pirofoszfát

Geranil-pirofoszfát

3-hidroxi-3-metilglutaril koenzim A

HMG-KoA szintáz

Nagyhatékonyságú folyadékkromatográfia

(High

Performance Liquid Chromatography)

HMG-KoA reduktáz degradációs útvonal (HMG-CoA reductase degradation pathway)

IPP izomeráz

Izopentenil-foszfát kináz

Izopentenil-pirofoszfát

Luria-Bertani broth (Luria-féle tápleves)

Mevalonsav-5-difoszfát dekarboxiláz

Metileritriol-4-foszfát útvonal

Mevalonsav útvonal

3-N-morfolin-propánszulfonsav

Mevalonsav-5-foszfát dekarboxiláz 


$\begin{array}{ll}\text { MVAP } & \text { Mevalonsav-5-foszfát } \\ \text { MVK } & \text { Mevalonsav kináz } \\ \text { OD } & \text { Optikai denzitás } \\ \text { PCR } & \text { Polimeráz láncreakció (Polymerase Chain Reaction) } \\ \text { PEG } & \text { Polietilén-glikol } \\ \text { PMC } & \text { PEG - szorbitol - MOPS - kálcium-klorid } \\ \text { PMK } & \text { Foszfomevalonsav kináz } \\ \text { RNáz } & \text { Ribonukleáz } \\ \text { SDS } & \text { Nátrium-lauril-szulfát } \\ \text { SMC } & \text { Szorbitol - MOPS - kálcium-klorid } \\ \text { SSC } & \text { Nátrium-klorid - nátrium-citrát } \\ \text { SZMC } & \text { Szegedi Mikrobiológiai Gyüjtemény (Szeged Microbiological } \\ & \text { Collection) } \\ \text { TAE } & \text { Tris - ecetsav - dinátrium-EDTA } \\ \text { TCM } & \text { Tris - kálcium-klorid - magnézium-klorid } \\ \text { YEG } & \text { Élesztőkivonat-glükóz tápközeg (Yeast Extract - Glucose } \\ & \text { medium) } \\ \text { YNB } & \text { Élesztő nitrogénforrás (Yeast Nitrogen Base) } \\ \text { YPG } & \text { Élesztökivonat - pepton - glükóz tápközeg (Yeast extract - } \\ & \text { Peptone-Glucose medium) } \\ & \end{array}$

A doktori értekezésben előforduló legfontosabb gének, illetve fehérjék és enzimek rövidítései:

Mucor circinelloides:

gpd

$h m g R$

HmgR

pyrG

Homo sapiens:

AMPK

gp78

HMGCR glicerinaldehid-3-foszfát dehidrogenáz

3-hidroxi-3-metilglutaril koenzim A reduktáz gén

3-hidroxi-3-metilglutaril koenzim A reduktáz

orotidin-5-monofoszfát dekarboxiláz 
Insig

Inzulin indukálta gén által kódolt fehérje (Insulin-induced gene protein)

$\mathrm{P} 97 / \mathrm{VCP}$

ATP-vezérelt valozint tartalmazó chaperon fehérje (ATPdriven chaperone valosin-containing protein)

SCAP

SREBP hasadást aktiváló fehérje (SREBP Cleavage Activating Protein)

SPFH2

Endoplazmatikus retikulum lipid raft-asszociált fehérje 2 (Endoplasmic reticulum lipid raft-associated protein 2)

SREBP-2

Szterol szabályozó elemet kötő fehérje (Sterol regulatory element-binding protein)

SREs

Szterol szabályozó elemek (Sterol Regulatory Elements)

TMUB1

Transzmembrán és ubikvitin-szerü domént hordozó fehérje 1

(Transmembrane and ubiquitin-like domain containing protein 1)

ubc 7

Ubikvitin-kapcsolt enzim 7 (ubiquitin-conjugating enzyme 7)

Saccharomyces cerevisiae:

HMG1

3-hidroxi-3-metilglutaril koenzim A reduktáz 1 gén

Hmg1p

3-hidroxi-3-metilglutaril koenzim A reduktáz 1 izoforma

$H M G 2$

3-hidroxi-3-metilglutaril koenzim A reduktáz 2 gén

Hmg2p

3-hidroxi-3-metilglutaril koenzim A reduktáz 2 izoforma

Nsp1p

Insig homológ

$\mathrm{Ubc7p}$

Ubikvitin kapcsolt enzim

Schizosaccharomyces pombe:

Hmg1

Ins1

Sty1 3-hidroxi-3-metilglutaril koenzim A reduktáz

Insig homológ fehérje

Stressz-érzékeny mitogén aktiváló protein kináz 


\section{BEVEZETÉS}

A terpének, azaz az izoprénvázas vegyületek, a természetben előforduló egyik legnagyobb és legváltozatosabb vegyületcsoportot alkotják. Részt vesznek a sejtmembrán felépítésében (koleszterin, ergoszterin) és a sejten belüli biokémiai folyamatokban. Lehetnek színanyagok (karotinok), valamint fontos szerephez jutnak a fotoszintézisben és a fotooxidatív védelemben is. Az élő sejtben betöltött fontos szerepük miatt bioszintézisük intenzíven kutatott terület. Ezenkívül a különböző iparágak is nagy mennyiségben hasznosítják őket.

A járomspórás gombák (Mucoromycotina) közé tartozó Phycomyces blakesleeanus, Blakeslea trispora és Mucor circinelloides a mikrobiális karotinoid bioszintézis tanulmányozásának modellorganizmusai. Közülük a Phycomyces-ben tanulmányozták legrészletesebben a karotinoidok bioszintézisének szabályozását. A karotinoidok és az egyéb izoprén származékok bioszintézisének korai szakasza megegyezik. Ez az úgynevezett mevalonsav bioszintézis útvonal (MEV), mely során az acetil-koenzim A-ból több lépésen keresztül kialakul az öt szénatomos izopentenil-pirofoszfát (IPP), ami a terpének közös építőköve. A mevalonsav bioszintézis útvonal központi lépése a 3-hidroxi-3-metilglutaril koenzim A (HMG-KoA) átalakulása mevalonsavvá, mely lépést a HMG-KoA reduktáz (HmgR) katalizálja. Mivel az enzim a korai izoprén bioszintézis egyik központi lépését határozza meg, így kihatással van az összes terpén termelődésére. A sztatin vegyületek az enzim szelektív gátlószerei. Humán gyógyászatban felhasználják őket a koleszterin szint csökkentésére, de gombaellenes hatásukat is vizsgálják.

Az HMG-KoA reduktáz gének száma az egyes élőlényekben eltérő. Az emlősökben általában egy reduktáz gén található, míg növényekben fajtól függően eltérő számban fordulnak elő. A járomspórás gombák genomja általában egy vagy két reduktáz gént kódol, azonban a $M$. circinelloides genomja 3 ilyen gént tartalmaz ( $h m g R 1, h m g R 2$ és $h m g R 3)$. Munkánk során tisztázni szeretnénk az egyes reduktázok specifikus szerepét a gomba izoprén bioszintézisében. Ezért a dolgozatban ismertetett vizsgálatok során a gének izolálását követően kísérletet tettünk a gének kópiaszámának emelésére és azok csendesítésére, valamint megvizsgáltuk, hogy e módosítások milyen hatással vannak a gombára. A gének kifejeződésének vizsgálatával képet szeretnénk kapni az egyes HMGKoA reduktázok szabályozásáról és a kifejeződésük esetleges eltéréseiröl.

Mind gyakorlati, mind pedig elméleti szempontból fontosnak tartottuk megvizsgálni a HMG-KoA reduktáz szerepét a Mucor sejten belüli folyamataiban (morfogenezis, 
apoptotikus folyamatok és stresszválasz). Ezen ismeretekröl kevés információval rendelkezünk, azonban fontosak lehetnek az esetleges biotechnológiai alkalmazások szempontjából. A szabályozó folyamatok feltárása hozzájárulna, hogy az eddigi karotinoid és terpén bioszintézis módosításával kapcsolatos eredmények felhasználásával egy, az iparban is jól használható karotinoid termelő törzset hozzunk létre. Az enzim ergoszterin bioszintézisben betöltött szerepének tisztázása pedig hasznos lehet új, a patogén gombákkal szembeni szerek kifejlesztésében is, valamint a környezethez való alkalmazkodás és a membránszerkezet kialakulásának tanulmányozása területén. 


\section{IRODALMI ÁTTEKINTÉS}

\subsection{A Járomspórás gombák (Mucoromycotina) általános jellemzői}

A Mucoromycotina az egyik legősibb szárazföldi gombacsoport melyhez a hagyományosan járomspórás gombáknak nevezett csoportok tartoznak, nevezetesen a Mucorales, Mortierellales és az Endogonales rend tagjai (Hibbett és mtsi. 2007). A Mucoromycotina tagjainak nagy része elhalt növényi maradványokon élő, szaprofita szervezet. Néhány faj parazita életmódot folytat, de találunk közöttük ektomikorrhiza alkotókat és obligát endoszimbiontákat is (Benny 2001; Benny és mtsi. 2001). Általánosságban elmondható, hogy cönocitikus micéliummal rendelkeznek (1/A ábra), sejtfalukban kitin és kitozán található. Ivartalan szaporító képleteik a sporangiumokban (1/B ábra) képződő sporangiospórák. Nevüket az ivaros szaporodás során létrejövő járomspóráról (zigospóra) kapták. Néhány csoportjukra jellemző a morfológiai dimorfizmus képessége, mellyel a környezeti körülményektől függően felvehetnek fonalas morfológiát, valamint növekedhetnek élesztőszerüen is (1/C ábra) (Ghormade és mtsi. 2012).
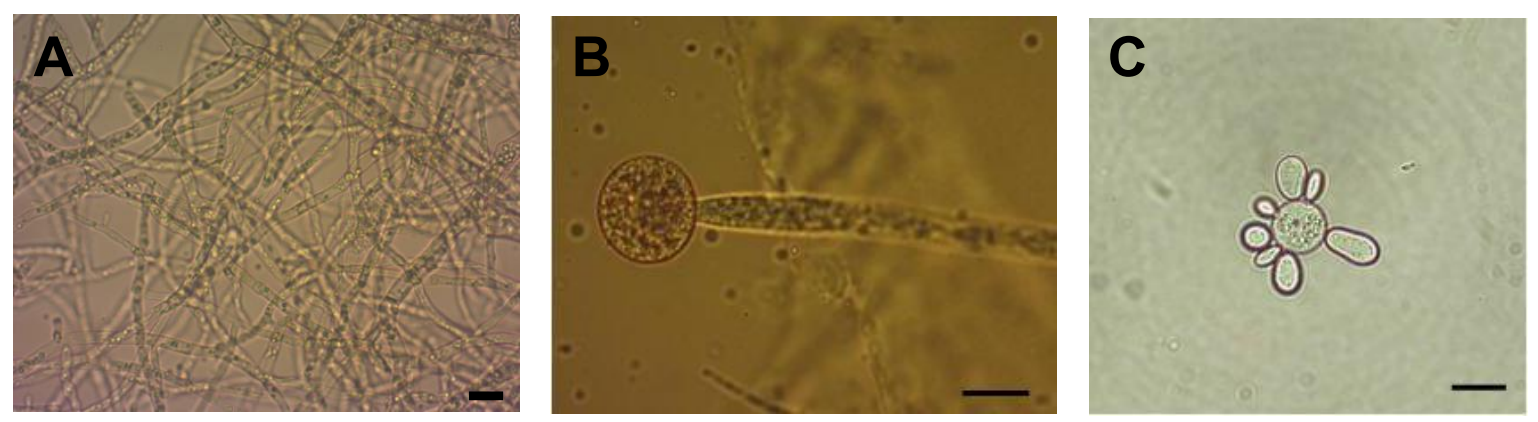

1. ábra. A M. circinelloides cönocitikus micéliuma (A), sporangiuma (B) és egy élesztőszerű morfológiát mutató sejtje $(\mathrm{C})$.

A méretskála értéke $20 \mu \mathrm{m}$.

A járomspórás gombák közé számos ipari és biotechnológiai jelentőségü gombafaj tartozik. Felhasználják őket extracelluláris enzimek (Godtfredsen 1990; Outtrup és Boyce 1990), többszörösen telítetlen zsírsavak (Carter 1988; Ward 1995; Yamada és mtsi. 1992), karotinoidok termeltetésére (Iturriaga és mtsi. 2000, 2001, 2005; Mehta és mtsi. 2003; Dufossé 2006), valamint szteroidvázas vegyületek sztereospecifikus hidroxilálására (Madyastha és Srivatsan 1987). Élelmiszeripari jelentőségük is nagy, mivel több Mucor, Rhizopus és Actinomucor faj képviselője megtalálható fermentációval készülő távol-keleti ételek starter kultúrájában (Han és mtsi. 2001). Számos fajnak jelentősége van a klinikumban is, mivel opportunista humán patogénként súlyos, úgynevezett zigomikózisokat válthatnak 
ki legyengült immunrendszerü betegekben (Ribes és mtsi. 2000; Walsh és mtsi. 2004; Chayakulkeeree és mtsi. 2006; Papp és mtsi. 2008).

A járomspórás gombák közül az egyik legjobban kutatott modellorganizmus a Mucor circinelloides. Az eddigi vizsgálatok elsősorban a gomba morfogenezisére és annak biokémiájára (Orlowsky 1991; Ruiz-Herrera 1993), a járomspórás gombák „szexferomonjának”, a trispórsavnak a bioszintézisére és a szexuális folyamatokban betöltött szerepére (Gooday 1994; Orlowsky 1994), a fényérzékelés molekuláris alapjainak tisztázására (Silvia és mtsi. 2006), valamint másodlagos metabolitok (pl. karotinoidok) bioszintézisére irányulnak (Iturriaga és mtsi. 1992, 2000, 2001, 2005; Navarro és mtsi. 2000; Papp és mtsi. 2006; Velayos és mtsi. 1997, 2000a, 2000b).

\subsection{A terpén típusú vegyületek jelentőségei}

A terpének ötszénatomos izoprén egységekből felépülő anyagok, melyek az egyik legnagyobb és legváltozatosabb természetes vegyületcsoportot alkotják (Misawa 2011). Számos terpén típusú vegyületet izoláltak már állatokból, növényekből és mikroorganizmusokból (Misawa 2011). Jelentőségüket mutatja, hogy a különböző iparágak nagy mennyiségben felhasználják őket. A gyógyszeriparban többek közt maláriaellenes szerként (pl. artemisinin) vagy antioxidáns hatásuk miatt táplálékkiegészítőként (pl. karotinoidok), a kozmetikai iparban illatanyagokként (pl. citronellol és geraniol), az élelmiszeriparban pedig szín- (karotinoidok) és aromaanyagokként (pl. limonén és linalool) használják őket. Ugyanakkor találkozhatunk még ezekkel a vegyületekkel a növénytermesztésben, hormonok, illetve hormonhatású vegyületek (giberellinek) formájában, valamint felhasználják öket az állati takarmányozásban a halak húsának és a tojás sárgájának az élénkítése (karotinoidok) céljából is (Misawa 2011).

Ezen kívül a sejtekben számos sejtbiológiai és biokémiai folyamat részét képzik. A karotinoidok a természetben előforduló legnagyobb pigmentcsoport. Fotoszintetizáló szervezetekben részt vesznek a fotoszintézis folyamatában, mint másodlagos fénygyűjtő molekulák (Britton és mtsi. 2008). Számos élőlényben fontos szerepet játszanak a fény által okozott stresszel szembeni védekezésben, illetve a szabadgyökök és a reaktív oxigénféleségek elleni fotooxidatív védelemben is. Részt vesznek a fototaxis és fototropizmus folyamataiban. Növények virágainak és terméseinek színanyagai és egyes fitohormonok prekurzorai lehetnek. A karotinoidok az A vitamin előanyagai, valamint antioxidáns tulajdonságokkal is rendelkeznek (Burton 1989; Paiva és Russel 1999; Naguib 2000). Állati és emberi kísérletekben az egyes karotinoidok (pl. $\beta$-karotin, asztaxantin, 
likopin) csökkentették a száj-, a prosztata-, a mellrák és egyéb daganatos elváltozások kialakulásának esélyét (Hennekens és mtsi. 1986; Vainio és Rautalahti 1998; Chew 1993; Chew és mtsi. 1999; Nishino és mts. 2002). Kedvezö hatásaik miatt egyre növekvő igény van természetes forrásból - így például mikrobiológiai forrásból - származó termékek iránt. Az iparban felhasznált karotinoidok többségét kémiai szintézissel állítják elö, vagy növényekböl vonják ki, azonban így csupán néhány vegyület állítható elő nagyobb mennyiségben (Johnson és Schroeder 1995; Bhosale 2004; Dufossé 2006, 2009; Mortensen 2006).

A járomspórás gombák ivaros folyamatai során keletkező járomspóra (zigospóra) kialakulása is szorosan összefügg a karotin bioszintézissel. A két, ellentétes párosodási típusba tartozó törzsben a párosodás során megnövekszik a $\beta$-karotin mennyisége (Schimek és mtsi. 2003), ebből a $\beta$-karotinból egy 18 szénatomos ketosav, az úgynevezett trispórsav keletkezik. A trispórsav a járomspórás gombákra jellemző szexferomon, amely szerepet játszik az ivaros differenciálódásban és a spóraképzésben is. A trispórsav, a párosodási folyamatoktól függetlenül is, serkenti a $\beta$-karotin termelődését. Ezt a hatást csak járomspórás gombáknál lehet kimutatni. Gilbertella persicaria esetében a termelt karotinoid mennyisége ötszörösére nőt a párosodás során (Papp és mtsi. 2009).

A szterinek fontos sejtmembrán alkotók (pl. koleszterin, ergoszterin), melyek felelősek a sejtmembrán szerkezetéért és fluiditásáért (Sharma 2006). A farnezol az opportunista humán patogén Candida albicans élesztő gombában, mint quorum sensing molekula játszik szerepet (Hornby és mtsi. 2001), ugyanakkor részt vesz az élesztő-micélium átmenet kialakulásában, így a gomba biofilm képzésében és virulenciájában is. Saccharomyces cerevisiae-ben a 3-hidroxi-3-metilglutaril koenzim A (HMG-KoA) reduktáz (HMGR) túltermelésével a farnezol mennyisége jelentősen megnőtt. Emlős sejtekben kimutatták, hogy a farnezol gátolja a mevalonsav bioszintézis útvonalban (MEV) szerepet játszó HMGR-t (Ong és mtsi. 2006).

A farnezil-pirofoszfát (FPP) és a geranilgeranil-pirofoszfát (GGPP) részt vesz a sejt szignáltranszdukciós folyamataiban szerepet játszó, GTPáz molekulacsaládba tartozó, Rho és Ras fehérjék prenilációjában (poszttranszlációs módosítás) is (Goldstein és Brown 1990). A Ras gének számos eukarióta élőlényben előfordulnak, és fontos szerepet játszanak a sejtek fejlődésében és osztódásában (Boguski és McCormick 1993; Bourne és mtsi. 1990; Ellis és mtsi. 1981; Vojtek és Channing 1998; Kataoka és mtsi. 1984; Powers és mtsi. 1984; Som és Kolaparthi 1994). 


\subsection{A terpén típusú vegyületek bioszintézise}

A terpén vegyületek bioszintézisének első lépése az ötszénatomos izopentenil pirofoszfát (IPP) kialakulása, amely a különböző élölényekben 3 útvonalon keresztül történhet (Lombard és Moreira 2011). Számos baktériumban, valamint a gombák, növények és állatok esetében az IPP a MEV útvonalon (2. ábra), az acetil-koenzim A kondenzációjával keletkezik több lépésen keresztül (Lombard és Moreira 2011). Baktériumokban és növények kloroplasztiszában azonosítottak egy másik, az ún. metileritriol-4-foszfát (MEP) útvonalat, melyben piruvátból és glicerinaldehid-3-foszfátból kiindulva alakul ki az IPP (Lombard és Moreira 2011). Eredetüket tekintve a MEV és a MEP bioszintézis egymástól független, nem homológ útvonalakon valósul meg.

acetil-KoA
HMG-KoA szintáz
HMG-KoA reduktáz

mevalonsav kináz

foszfomevalonsav kináz

mevalonsav-difoszfát dekarboxiláz
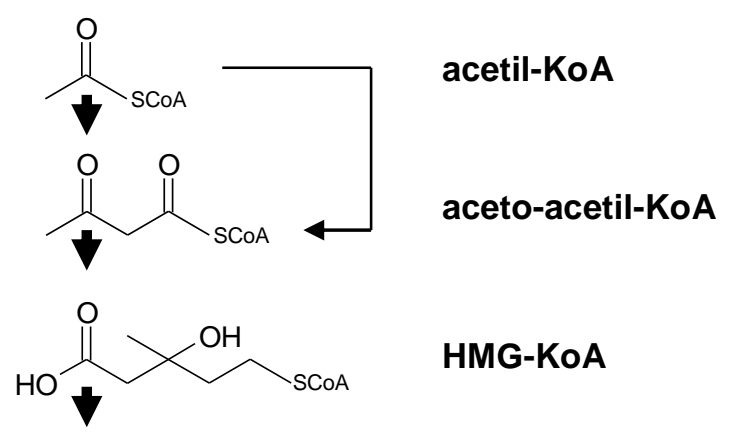

HMG-KoA<smiles>CC(O)(CCO)CC(=O)O</smiles>

mevalonsav<smiles></smiles>

mevalonsav-P

mevalonsav-PP<smiles>C=C(CCOP)CC(C)(O)CCOP</smiles>

mevalonsav-PP

izopentenil-PP

2. ábra. A klasszikus mevalonsav (MEV) útvonal.

Dellas és mtsi. (2013) a legújabb filogenetikai és kísérleti adatok alapján arra a megállapításra jutottak, hogy létezik egy alternatív mevalonsav útvonal is egyes archeákban. Az alternatív és a klasszikus MEV útvonal a mevalonsav-5-foszfát (MVAP) kialakulásáig megegyezik. Míg a klasszikus MEV útvonalon a MVAP - IPP átalakulást a foszfomevalonsav-kináz (PMK) és a mevalonsav-5-difoszfát dekarboxiláz (MDC), addig az alternatív útvonalon egy mevalonsav-5-foszfát-dekarboxiláz (MPD) és egy izopentenilfoszfát-kináz (IPK) katalizálja. 
Járomspórás gombákban a klasszikus MEV útvonalon keresztül zajlik a terpének bioszintézise (2. ábra). Első lépésben acetil-koenzim A-ból egy acetoacetil-koenzim A tioláz (AACT) segítségével acetoacetil-koenzim A keletkezik, melyet a 3-hidroxi-3-metilglutarilkoenzim A szintáz (HMGS) alakít át 3-hidroxi-3-metilglutaril-koenzim A-vá (HMG-KoA). A HMG-KoA a MEV útvonal kulcs intermedierje, melynek redukálását a HMG-KoA reduktáz (HmgR) végzi, létrehozva így a mevalonsavat. A mevalonsavból mevalonsav kináz (MVK) segítségével mevalonsav-5-foszfát jön létre. A PMK a mevalonsav-5-foszfátból mevalonsav-5-difoszfátot képez, ezt a mevalonsav-5-dekarboxiláz (MDC) alakítja át izopentenil-pirofoszfáttá (IPP).

Az IPP kialakulását követően az IPP-izomeráz (IDI) segítségével alakul ki a dimetilallil-pirofoszfát (DAPP). Streptomyces-ben felfedeztek egy az IDI-vel nem homológ enzimet, amely ugyanezt a lépést katalizálja (Kaneda és mtsi. 2001).

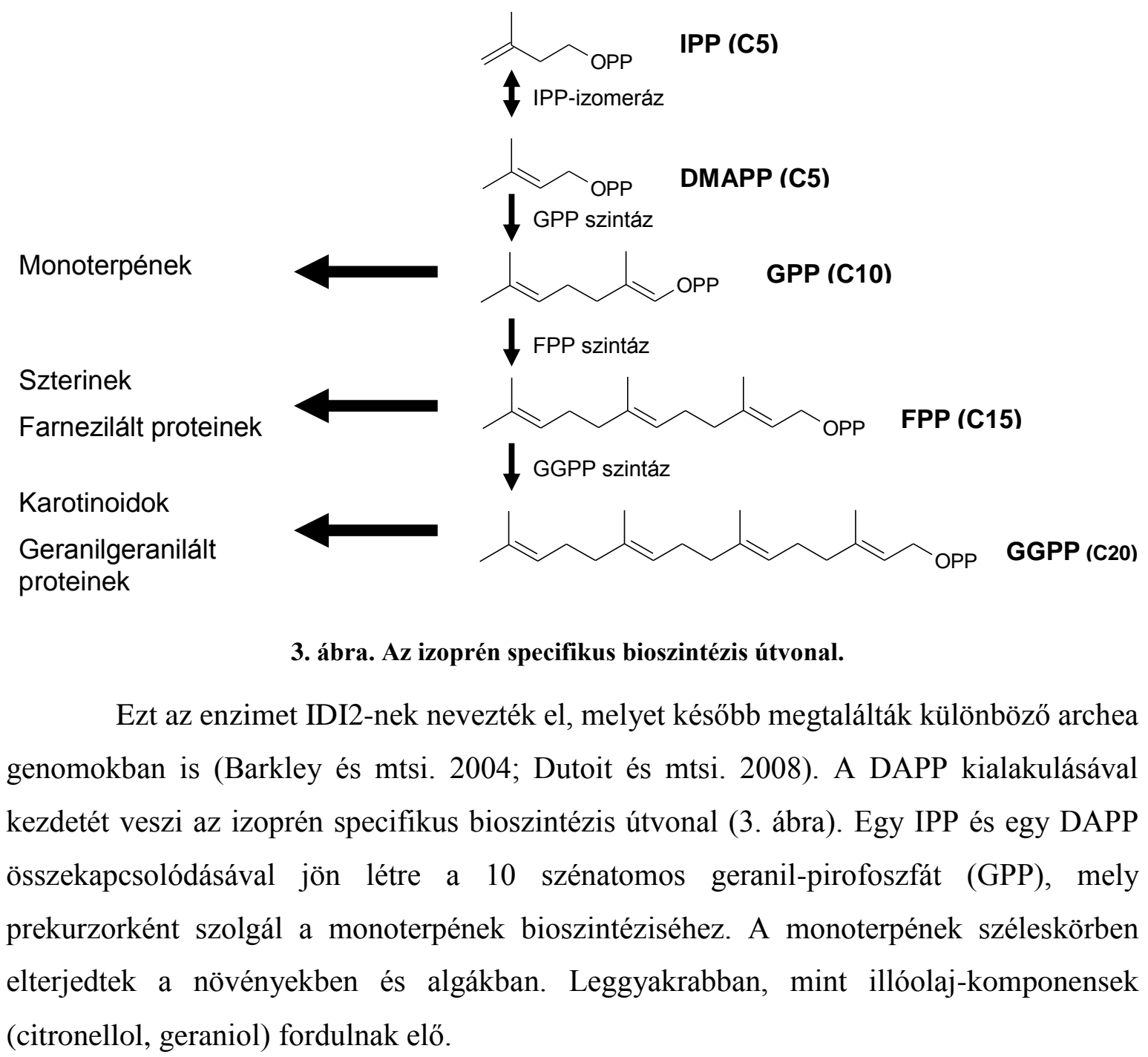


A GPP és egy újabb IPP kondenzációjával, melyet a farnezil-pirofoszfát szintáz katalizál, alakul ki a 15 szénatomos farnezil-pirofoszfát (FPP), melyből a szeszkviterpének (farnezol), triterpének és szterinek alakulnak ki.

Az izoprén bioszintézis útvonal további szakaszában az FPP-hez egy újabb IPP egység kapcsolódásával létrejön a 20 szénatomos geranilgeranil-pirofoszfát (GGPP), melyről a diterpének és a karotinoidok specifikus bioszintézis útvonalai ágazódnak le.

Korábban vizsgálták az egyes terpénszármazékok képződési folyamatait radioaktívan jelölt acetil-KoA, leucin és mevalonsav segítségével az ugyancsak járomspórás P. blakesleeanus és B. trispora gombákban. Az eredmények azt mutatták, hogy az ergoszterin, a karotinoidok és a triacilglicerinek már az acetil-KoA felhasználásától kezdve egymástól elkülönülve, feltételezhetően specifikus kompartmentekben, de mindenképpen saját külön prekurzorkészlet felhasználásával szintetizálódnak (Bejarano és Credá-Olmedo 1992; Kuzina és mtsi. 2006). Feltehetőleg az ergoszterin és az ubikinon ugyanazon kompartmentben szintetizálódik, ugyanis képződésük során közös prekurzorkészletet használnak.

\subsection{A HMG-KoA reduktáz}

A 3-hidroxi-3-metilglutaril koenzim A reduktáz (HmgR) egy NADP koenzim segítségével működő oxidoreduktáz, mely a MEV útvonal központi lépését katalizálja (4. ábra).

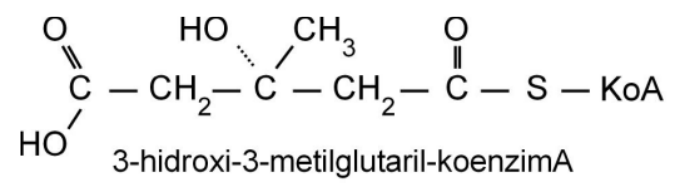

$2 \mathrm{NADH}+2 \mathrm{H}^{+}$<smiles>CC(O)(CCO)CC(=O)O</smiles>

$2 \mathrm{NAD}+2 \mathrm{KoA}-\mathrm{SH}$

4. ábra. A HMG-KoA redukciója mevalonsavvá.

Filogenetikai elemzések alapján az enzimet két típusba lehet sorolni (Friesen és Rodwell 2004; Heidl és mtsi. 2004; Lombard és Moreia 2011). Az I. típusú enzim eukariótákban, archeákban, néhány proteo és aktinobaktériumban, míg a II. típusba tartózó enzim, baktériumokban és néhány archeában fordul elő. Az I. típusú enzim kettő fő domént tartalmaz. A fehérje $\mathrm{N}$-terminális részén a hidrofil transzmembrán domént, C-terminális részén pedig a hidrofób, katalitikus aktivitásért felelős régiót tartalmazza. A két domén között egy rövid linker régió található. Ezzel szemben a II. típusú enzim nem tartalmaz transzmembrán és linker régiót, az enzim sejten belül szolubilis formában van jelen. A 
biokémiai vizsgálatok azt mutatják, hogy a két osztály azonos eredetü aktív centrummal rendelkezik. Ugyancsak megegyezik a homodimer képzésük, viszont eltérő a kofaktor használatuk és másképp hatnak rájuk a sztatinok. A sztatinok a HMG-KoA reduktáz szelektív gátlószerei, melyeket koleszterinszint csökkentésre használnak a humán gyógyászatban. Az I. típusú enzim sokkal érzékenyebb ezekre a vegyületekre, mint a II. típusú (Friesen és Rodwell 2004).

A HMG-KoA reduktáz gén szekvenciájára és fehérje szerkezetére vonatkozó adatok számos eukarióta szervezetben ismertek, mint például Arabidopsis thaliana (Caelles és mtsi. 1989), S. cerevisiae (Basson és mtsi. 1988), Drosophila melanogaster (Gertler és mtsi. 1988), Rhizomucor miehei (Lukács és mtsi. 2009), P. blakesleeanus (Ruiz-Albert és mtsi. 2002).

A HMG-KoA reduktáz gének az egyes organizmusokban eltérő számban fordulnak elő. Emlősökben általában egy, míg növényekben fajtól függően egy multigén család kódolja őket (Stermer és mtsi. 1994). A gének száma a gombákban is igen változatos. Schizosaccharomyces pombe esetében egy (Lum és mtsi. 1996), míg S. cerevisiae esetében kettő HMG-KoA reduktáz gént (Basson és mtsi. 1986) azonosítottak. A járomspórás gombák genomja egy vagy több HMG-KoA reduktáz gént kódol. Az Absidia glauca (Burmester és Czempinski 1994), P. blakesleeanus (Ruiz Albert és mtsi. 2002), R. miehei (Lukács és mtsi. 2009) egy, a M. mucedo és a Parasitella parasitica (Burmester és Czempinski 1994) kettő $h m g R$ gént hordoz. Több járomspórás gomba HMG-KoA reduktázának egy rövid szakaszát összehasonlítva, arra a következtetésre jutottak, hogy a járomspórás gombák szétválása előtt egy génduplikációs esemény történt a járomspórás gombák ősében (Ruiz-Albert és mtsi. 2002). Később egyes fajok az egyik gént elvesztették, míg más fajokban további duplikáció is történt (Lukács és mtsi. 2009). A legújabb kutatási eredmények azt mutatják, hogy a járomspórás gombák esetében nem csak génduplikációs események, hanem teljes genom duplikáció is történhetett (Gryganskyi és Muszewska 2014).

Az I. típusú enzim transzmembrán régiója fajtól függően meglehetősen variábilis, általában 2-8 transzmembrán hélixet tartalmaz. A járomspórás gombák közül a $R$. miehei HMG-KoA reduktáza 7, míg a $P$. blakesleeanus esetében 8 transzmembrán szakaszt hordoz. A hidrofób N-terminális rész a transzmembrán hélixeken kívül tartalmaz egy ún. szterol érzékelő domént (SSD) is, mely részt vesz az enzim poszttranszlációs szabályozásában (Loftus és mtsi. 1997; Brown és Goldstein 1999; Davies és Ioannou 2006). A HMG-KoA reduktáz igen erős szabályozás alatt áll, mely a transzkripció, a transzláció és a poszt- 
transzláció szintjén is megnyilvánul (Goldstein és Brown 1990). A fehérje C-terminális régiója, mely az enzim katalitikus aktivitásáért felelős, erősen konzervált (Hampton és Rine 1994).

Az enzim sejten belüli lokalizációja eltérő lehet. Általában az endoplazmatikus retikulumhoz (ER) horgonyzódik ki, de van példa peroxiszómális és mitokondriális lokalizációra is. Emlősök esetében a HMG-KoA reduktáz (HMGCR) egy 97 kDa nagyságú protein, mely hét transzmembrán régió segítségével az endoplazmatikus retikulum membránjához horgonyzódik (Liscum és mtsi. 1985). Ugyanakkor kimutatták, hogy létezik egy második izoforma is, amely az előzőtől függetlenül kódolt és a peroxiszómák mátrixában fordul elő (Breitling és Krisans 2002). A peroxiszómális HMGCR a normál enzimaktivitás 5\%-át teszi ki (Keller és mtsi. 1986), mérete kisebb, mindössze $90 \mathrm{kDa}$ (Engfelt és mtsi. 1997), és szabályozásában is eltér az ER-ben előforduló enzimétől (Aboushadi és mtsi. 2000). Az extremofil Hortaea werneckii gombában két izoformáját azonosították az enzimnek, melyek közül egyik a mitokondriumban, a másik pedig az ERben lokalizálódik (Vaupotič és Plemenitas 2007). A. thaliana genomjában két HMG-KoA reduktáz gén található, melyekről az enzimnek három izoformája keletkezik. A három izoforma egyenként $75 \mathrm{kDa}$ nagyságú és egy vagy két transzmembrán régiót hordoznak, mely segíti az enzim szállítását az ER-ből a mitokondriumba vagy a kloroplasztiszba (Learned és Fink 1989; Leivar és mtsi. 2005; Stermer és mtsi. 1994).)

A S. cerevisiae genomja két HMG-KoA reduktáz izoenzimet kódol (Hmg1p és Hmg2p). Mind a két fehérje az ER-hez kötődik, de azon belül elkülönül a lokalizációjuk egymástól (Koning és mtsi. 1996). A Hmglp az ER sejtmag felöli részén helyezkedik el és részt vesz az ER proliferációjában, míg a Hmg2p az ER perifériáján található. Feltehetőleg a HmgR2p fontos szerepet tölt be az anaerob körülményekhez való adaptálódásban, ugyanis kifejeződése anaerob körülmény között megnő, míg a Hmglp kifejeződése lecsökken. Különbség van a két enzim szabályozásában is. A Hmg1p enzim sokkal stabilabb és a Hmg2p-vel ellentétben a degradációjában nem játszanak szerepet a mevalonsav bioszintézis út nem-szterin metabolitjai.

\subsection{A HMG-KoA reduktáz enzim jelentősége}

Az irodalomból ismert, hogy a HMG-KoA átalakulása mevalonsavvá a MEV bioszintézis út központi, sebességmeghatározó lépése. A mevalonát útvonal végén keletkező IPP-vel veszi kezdetét a terpén specifikus útvonal. Az útvonalon keletkező egyes izoprén 
termékek hatással vannak a MEV útvonal enzimeire, köztük a HMG-KoA reduktáz keletkezésére, stabilitására és degradációjára (Goldstein és Brown 1990).

A HMG-KoA reduktáz sejten belül betöltött központi szerepe a különböző izoprénvázas vegyületek bioszintézisére gyakorolt közvetlen hatásában fejeződik ki, melyek olyan változásokat indukálnak, amik alapvető hatással lehetnek az adott organizmus morfogenezisére, virulenciájára és/vagy a megváltozott környezethez való adaptálódási képességére. Az 5. ábrán az enzim közvetlen és közvetett hatásai láthatóak.

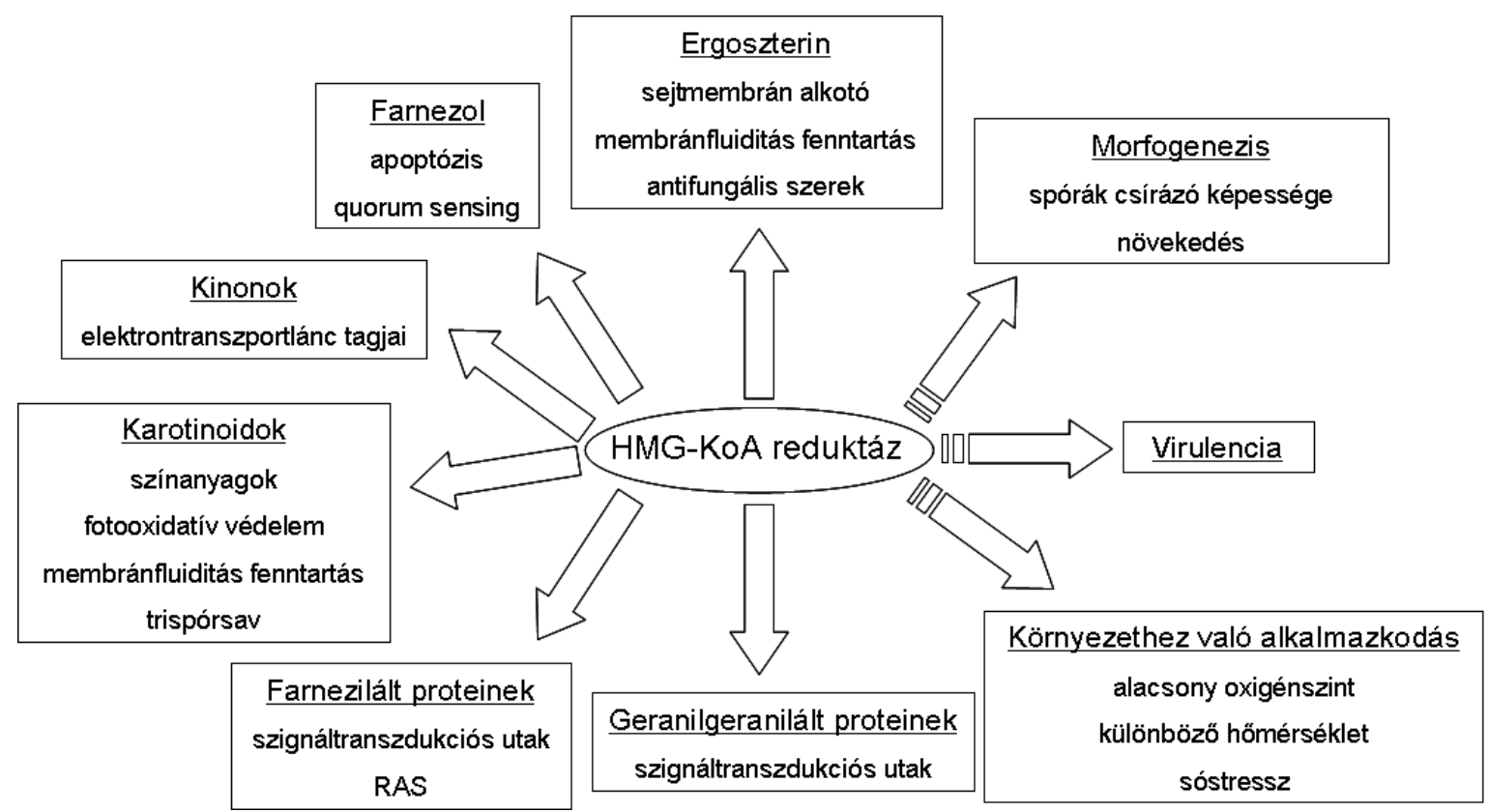

5. ábra. A HMG-KoA reduktáz közvetlen (nyíl) és közvetett (szaggatott nyíl) hatása a különböző sejten belüli folyamatokra.

Számos kutatás indult a HMG-KoA reduktáz karotinoid bioszintézisben betöltött szerepének tanulmányozására az elmúlt években. A Candida utilis tartalmazza az izoprének bioszintéziséhez szükséges prekurzorokat és enzimeket, azonban nem képes karotinoidok termelésére. Bakteriális eredetű génekkel transzformálva az élesztőt, karotinoid termelő törzset hoztak létre (Misawa és Shimada 1997). Izolálták a C. utilis HMG-KoA reduktáz 1 génjét (hmgRl), melyet túlmüködtetve az élesztő sejtben, sikerült a MEV útvonalon keresztül a termelt karotinoid mennyiségét négyszeresre növelni. Mindeközben az ergoszterin mennyisége alig változott. Hasonló módon hoztak létre karotinoid termelésre alkalmas $S$. cerevisiae törzset is, melyben a $C$. utilis $h m g R l$ génjének katalitikus doménjét túlmüködtetve fokozni tudták a karotin produkciót (Verwaal és mtsi. 2007). Yan és munkatársai (2012) karotin termelö, rekombináns S. cerevisiae-ben képesek voltak a HMGKoA reduktáz túlműködtetése mellett úgy növeli a termelődő karotinoid mennyiséget, hogy 
közben ketokonazollal gátolták az ergoszterin bioszintézis utat. Ezáltal az izoprén specifikus bioszintézis úton keletkező FPP nagy része a karotin bioszintézisre fordítódott. A $R$. miehei HMG-KoA reduktáz génjét izolálva és $M$. circinelloides-ben túlmüködtetve nem tapasztaltak a karotin termelésben szignifikáns változást, ugyanakkor a transzformánsok sztatinokkal szembeni érzékenysége jelentősen csökkent (Lukács és mtsi. 2009).

Basson és munkatársai (1986) megfigyelték, hogy S. cerevisiae-ben az enzim fontos szerepet játszik a spórák csírázásában és a vegetatív sejtek növekedésében. Létrehoztak olyan deléciós mutáns törzseket, melyekben hol az egyik, hol a másik $H M G$ gént törölték. Arra a megállapításra jutottak, hogy a sejt életben maradása szempontjából elégséges egyetlen $H M G$ gén, viszont a két gén egyidejü deléciója letális (Basson és mtsi. 1987; Seong és mtsi. 2006). Az izoprén specifikus bioszintézis útról leágazó termékek, köztük a farnezol és geranilgeranol, negatív visszacsatolással szabályozza élesztőben a gén kifejeződését.

Joo és Jetten (2010) munkájukban leírták, hogy emlős sejtekben a farnezol indukálta apoptózist az enzimszint mennyiségének csökkenése kísérte, ezenkívül az enzim gátlása révén az ER-ben stresszválasz indukálódik, mely szintén apoptózishoz vezet. $C$. albicans-ban szintén megfigyelték a farnezol szerepét az apoptotikus folyamatokban (Shirtliff és mtsi. 2009). Emlős és gomba sejtekben a sztatinok - a HMG-KoA reduktáz szelektív gátlószerei - a protein prenilációjának indirekt gátlásán keresztül gátolják a Ras fehérje termelődését. Lovasztatinnal indukált apoptózist humán rákos sejtvonalakban is megfigyeltek (Agarwall és mtsi. 1999). Korábban vizsgálták a M. racemosus Ras fehérjéinek (RAS1, RAS2 és RAS3) kifejeződését és a sejtek morfológiájára kifejtett hatását (Roze és Linz 1998). Mindhárom RAS fehérje kifejeződése a fonalas növekedés során volt erőteljes, míg az élesztőszerű növekedés alatt kifejeződésük csökkent. A preniláció gátlása (a HMGKoA reduktáz kompetitív gátlószereinek alkalmazásával) akadályozta a RAS fehérjék érését, ezáltal csökkent a gomba növekedése és a sporangiospórák kialakulásának a mértéke is. Ezen változások a gombasejtekben apoptózis-szerü folyamatokat indítottak el, melyek végül a gombasejtek halálához vezettek (Roze és Linz 1998).

Halofil élesztőgombákban az enzim hozzájárul a halotoleráns fenotípus kialakításához. H. werneckii esetében az optimális sókoncentráció mellett az enzim degradációjának mértéke csökkent, míg az optimálistól eltérő, magasabb, illetve alacsonyabb sókoncentráció mellett az enzim aktivitása megnőtt. Lovasztatinnal történő kezelés hatására ozmotikusan szenzitív fenotípus jelent meg (Vaupotič és mtsi. 2008). Az extrém környezethez való alkalmazkodás az extremofil mikroorganizmusok számára létfontosságú. Haloferax volcanii archea baktériumnál a sókoncentráció változásával 
párhuzamosan változott a sejtmembrán lipid- és karotinoid tartalma (Bidle és mtsi. 2007). Sóérzékeny $S$. cerevisiae esetében leírták, hogy mind alacsony, mind magas sókoncentráció mellett 2-6 szorosára nőtt az enzim aktivitása. A termelődő fehérje mennyisége párhuzamban állt az enzim aktivitásával. Az eredmények azt mutatták, hogy az enzim részt vesz a sóstresszhez való alkalmazkodásban.

A HMG-KoA reduktáznak nem csak a környezethez való alkalmazkodásban és a sejten belüli biokémiai folyamatokban van szerepe, hanem patogén gombákban kihat a virulenciára is. Seong és munkatársai (2006) létrehoztak egy olyan mutáns Fusarium graminearum törzset, melyben a HMG-KoA reduktáz katalitikus doménje érintetlen maradt, azonban a transzmembrán régióban mutáció történt. Ezekben a mutánsokban a növekedési ráta lelassult, valamint csökkent virulenciát mutattak búzanövénnyel szemben.

Növényekben az izoprén bioszintézis út egyes termékei (szterinek, fitoalexinek, hormonok, karotinoidok) fontos szerepet töltenek be a fiatal növény növekedésében és fejlődésében. A HMG-KoA reduktáz gén aktivitása és kifejeződése az egyes szövetekben specifikusan meghatározott időben történik. Az intenzív sejtosztódás során (a magfejlődés korai szakaszában) a legmeghatározóbbak azok az izoprén komponensek, melyek részt vesznek a membránok kialakításában, illetve azok, melyek az elektron transzportlánc tagjai (Moore és Oishi 1993). A magfejlődés során és az embrióban igen magas HMG-KoA reduktáz aktivitás értéket mértek (Stermer és mtsi. 1994).

\subsection{A HMG-KoA reduktáz szabályozása}

\subsubsection{A HMG-KoA reduktáz szabályozása emberben}

Emberben a HMGCR egyik fő transzkripciós faktora az úgynevezett szterin regulációs elem-kötő fehérje 2 (SREBP-2) (Horton és mtsi. 2002; Burg és Espenshade 2011). Az ER-hez kötődő SREBP komplexet alkot az ugyancsak membrán kötött, a SREBP hasítását aktiváló fehérjével (SCAP). Az így létrejött SREBP-SCAP komplex érzékeli a sejten belüli szterin szintet. Az Insig (inzulin indukálta gén által kódolt fehérje) képes a HMGCR-t transzkripcionálisan és poszttranszlációsan is szabályozni. A transzkripcionális szabályozás során az Insig meggátolja a SREBP aktivációját. Alacsony koleszterinszint esetén az Insig lehetővé teszi a SREBP-SCAP komplex aktivációját és az ER-ből a Golgi apparátusba történő szállítását. A Golgi apparátusban a SREBP-ről két proteolitikus hasítás eredményeként a fehérje N-terminális transzkripciós faktor doménje leválik. Ez a domén belép a sejtmagba, ahol úgynevezett szterol regulációs elemeket (SREs) ismer fel. A 
transzkripciós faktor kötődik a HMGCR promóterében található SRE elemhez és megindítja a gén transzkripcióját (Burg és Espenshade 2011).

Az Insig nem csak a HMGCR aktiválásában vesz részt, hanem a degradációjában is az úgynevezett szterin-érzékelő visszacsatolási-gátlási rendszeren keresztül. Magas szterin szint mellett az Insig köti a HMGCR N-terminális részét, ezáltal megtörténik az enzim ubikvtinálódása és gyors degradációja. Az Insig együttmüködik a gp78 (glikoprotein 78) membrán kötött ubiquitin E3 ligázzal, mely a citoplazma felöli oldalán magához toborozza az ubc7-t (ubikvitin kapcsolt fehérje), valamint a p97/VCP (ATP-vezérelt valozin tartalmazó chaperon fehérje) ATPázt. A membránban a gtp78-t köti a TMUB1 (transzmembránt és ubikvitin-szerü domént tartalmazó fehérje) az SPFH2 (endoplazmatikus retikulum lipid raftasszociált fehérje). Az így létrejövő komplex hatására ubikvitinálódik a HMGCR, leválik a membránról és elindul a degradációja. Ezt az Insig-függő lebontást kétféle szignál váltja ki: a szterinszármazékok és a 20 szénatomos geranilgeraniol (GGOH). Mindkét szignál hatással van a HMGCR degradációjára, de különböző módon. A GGOH nem szükséges a HMGCR ubikvitinálódásához, de fokozza azt, míg bizonyos oxiszterinek és a koleszterin bioszintézis köztiterméke a 24,25-dihidrolanoszterol szükséges az Insig-HMGCR kötődésért. Mivel a koleszterin szintézis erősen oxigénigényes folyamat, alacsony oxigénszint mellett a lanoszterol metil csoportjainak eltávolítása gátolt, így ez a köztitermék felhalmozódik a sejten belül elősegítve a HMGCR-Insig kötődést. Egy molekula koleszterin acetil-KoA-ból történő szintézise során 11 molekula dioxigén szükséges, mely 9 a metil csoportoknak a lanoszterolról való eltávolításához szükséges (Nguyen és mtsi. 2007).

Létezik egy Insig független mechanizmus is. Metabolikus stressz során ez a mechanizmus segíti a sejt ATP felhasználását. Ez a sejtanyagcsere állapot az, amely szabályozza a HMGCR degradációját. Az AMPK (AMP-aktiválta protein kináz) egy hetero trimer komplex, mely két szabályozó alegységet ( $\beta$ és $\gamma$ ) és egy katalitikus alegységet $(\alpha)$ tartalmaz. A $\gamma$ köti az adenozin nukleotidokat és részt vesz az energiaérzékelésben. Az AMP allosztérikusan aktiválja az AMPK-t, erre az ATP nem képes, mivel az AMP és az ATP versenyez az AMPK kötőhelyéért. Az AMPK képes érzékelni az AMP: ATP arányt és ennek megfelelöen növeli a katalitikus aktivitását. Ha aktiválódott, akkor képes az enzimen található (S872) aminosavat foszforilálni, így csökkenti a HMGCR aktivitását. A foszforilálás eredményeként az enzim NADP-hoz való affinitása lecsökken. A defoszforiláció képes teljesen helyreállítani az enzim müködését. A defoszforilációt a PP2A nevü protein foszfatáz végzi (Burg és Espehnsade 2011). 


\subsubsection{A HMG-KoA reduktáz szabályozása gombákban}

Gombák esetében e folyamatokat legalaposabban a $S c h$. pombe és a $S$. cerevisiae élesztőkben tanulmányozták.

\subsubsection{Schizosaccharomyces pombe}

A Sch. pombe egy HMG-KoA reduktázzal (Hmg1) rendelkezik, mely 8 transzmembrán hélixet tartalmaz (Lum és mtsi. 1996). Az enzimben, a humán reduktázhoz hasonlóan, fellelhető az AMPK általi foszforiláció célpontjául szolgáló szerin (S1024). Megtalálható a hasadó élesztőben egy Insig homológ (Ins1) fehérje is, mely az emlős Insiggel ellentétben nem szabályoz a SREBP-SCAP útvonalon keresztül, de stabil komplexet képez a Hmg1-gyel. Az Ins1 nem-degradatív útvonalon keresztül szabályozza a Schizosaccharomyces Hmg1-t. Az Ins1-Hmg1 komplex elősegíti a S1024 és a T1028 foszforilációját, ezáltal csökkentve az enzim aktivitását. Ez a gátlás növeli a NADP Km értékét. Ezt a foszforilációt ozmotikus stressz és alacsony glükóz szint indukálja. Ozmotikus stressz és minimál táptalajon való növekedés során a Hmg1 foszforilációjához szükséges a Sty1 (stressz-érzékeny mitogén aktiváló protein kináz), a Wis4 és Wis1. Alacsony glükóz szint erősen indukálja a Hmg1 foszforilációját. Ennek szabályozásában részt vesz a PP2Ahoz hasonló Ppe1 foszfatáz és annak negatív regulátora, az Sds23. A Ppe1 az enzim defoszforilációjáért felelős, azonban magas glükóz szint esetén az Sds23 meggátolja a Ppe1 működését. Emlősben a HMGCR foszforilációja alacsony glükóz szint mellett az AMPK-n keresztül zajlik. A Sch. pombe AMPK homológ nem szükséges a glükóz-függő foszforilációhoz. Ellenben, ahogy az emlős sejtekben az AMPK $\gamma$ alegység, úgy az Sds 23 is tartalmaz CBS domént, ami felveti annak lehetőségét, hogy a Hmg1 szabályozásában, az emlős HMGCR-éhez hasonlóan, szerepe van az adenozin nukleotid szint érzékelésének.

A hasadó élesztőben megtalálható az úgynevezett Sre1 és Scp1 fehérje, melyek SREBP és SCAP ortológok (Hughes és mtsi. 2005, 2007). A Sre1 is tartalmaz egy hélixhurok-hélix motívumot, melynek segítségével képes az emlősökben található SRE elemekhez kötődni (Todd és mtsi. 2006). A SCAP és Scp1 fehérjék azonossága csak arra a három konzervált szterin-érzékelő doménra korlátozódik, melyek ahhoz elegendőek, hogy a fehérjét az endoplazmatikus retikulumba tartsák

A Srel részt vesz azokban a folyamatokban, melyekkel a sejt képes a környezet oxigén koncentrációját érzékelni és adaptálódni az alacsony oxigénkoncentrációhoz (Espenshade 2006; Hughes és mtsi. 2005; Todd és mtsi. 2006). Anaerob körülmények között a Sre1 fehérje aktiválódik és felhalmozódik a sejtmagban. Transzkripcionális 
aktivátorként kezd el viselkedni, mely olyan gének átíródását aktiválja, melyek szükségesek az alacsony oxigén szint melletti növekedéshez. Ezek olyan enzimek génjei, amelyek nagy mennyiségü oxigént igénylő folyamatokat katalizáló reakciókban vesznek részt (pl. az ergoszterin, hem, szfingolipid, és ubikinon bioszintézis egyes oxigén igényes lépései) (Todd és mtsi. 2006).

\subsubsection{Saccharomyces cerevisiae}

A S. cerevisiae két HMG-KoA reduktáz génje (HMG1, HMG2) különböző módon regulálódik. Aerob körülmények között hem képződik, mely aktiválja a Hap1p transzkripciós faktort. Ezután a Haplp aktiválja a HMG1 transzkripcióját. Ezzel párhuzamosan egy, még ismeretlen mechanizmus gátolja a HMG2 kifejeződését. Mevalonsav éheztetett sejtekben akkumulálódik a Hmglp fehérje és emelkedett aktivitást mutat. A Hmg2p, az emlős sejtekhez hasonlóan, az ER-kapcsolt degradáció (ERAD) útján szabályozódik. A Hmg2p-t felismeri és ubiquitinálja a membrán kötött HRD (HMG-KoA degradációs útvonal) komplex. A membrán kötött Hrd1P E3 ligáz az Ubc7p (ubikvitin konjugáló enzim) fehérjével ubikvitinálja a Hmg2p-t, mely ezután leválik a membránról és degradálódik. A Hmg2p degradációját a nem szterin izoprének és a szterinek kontrollálják. A nem szterin izoprének közül a 20 szénatomos GGPP a legfontosabb szignálkomponens. Az emelkedett Hmg2p aktivitás növeli a keletkező GGPP mennyiségét, mely negatív visszacsatolás útján indukálja az enzim degradációját. A szterin szignál, az oxiszterin, mely ugyan nem szükséges az enzim degradációjához, de fokozza azt. A S. cerevisiae-ben az Insig ortológját Nsp1p-nek nevezik, mely köti a Hmg2p-t és szabályozza a fehérje mennyiségét és stabilizálja azt (Burg és Esphensade 2011).

Az élesztő nem rendelkezik SREBP és SCAP fehérjékkel. Alacsony szterin szint esetén az Upc2p és Ecm22p transzkripciós faktorok kontrollálják a szterin bioszintézist (Vik és Rine 2001). Ezek a fehérjék a SREBP génnel nem mutatnak homológiát (Dimster-Denk és Rine 1996; Smith és mtsi. 1996). Alacsony oxigén szint esetén az Upcp2 az AUS1 és PDR11 ABC transzporterek expresszióját indukálja, melyek segítik az exogén szterin felvételt. 


\section{CÉLKITÜZÉSEK}

Mivel a HMG-KoA reduktáz a terpén bioszintézis korai szakaszának központi lépését katalizálja, hatással lehet számos vegyület, többek közt a karotinoidok és az ergoszterin, valamint az ubikinon és egyes fehérjék prenil csoportjainak képződésére. Közvetlenül vagy az említett metabolitok szintézisén keresztül olyan fontos biológiai folyamatokat befolyásolhat, mint a membrán szerkezet kialakítása, a különböző környezeti faktorokhoz való alkalmazkodás, a morfogenezis, vagy az apoptotikus folyamatok. Mindezeket figyelembe véve fó célunk a karotinoid termelő járomspórás gomba, a $M$. circinelloides HMG-KoA reduktáz génjeinek azonosítása, funkcionális vizsgálata és az izoprén bioszintézisben betöltött, esetlegesen eltérő, szerepük tisztázása.

Ennek érdekében a következő konkrét célokat tüztük ki magunk elé:

\section{A M. circinelloides HMG-KoA reduktáz génjeinek izolálása és elemzése.}

2010-ben fejeződött be a M. circinelloides teljes genomszekvenciájának

meghatározása (http://genome.jgi-psf.org/Mucci2/Mucci2.home.html), mely nagymértékben megkönnyíti az izoprén bioszintézisben szerepet játszó gének azonosítását és jellemzését. Célul tüztük ki egyes rokon fajok $h m g R$ gén szekvenciájának segítségével homológ génszakaszok keresését a $M$. ciricnelloides genomban, majd az így talált szekvenciák in silico elemzését. Az így nyert adatok alapján terveztük a legnagyobb homológiát mutató, feltételezett gének izolálását és klónozását is.

\section{A hmgR gének kifejeződésének vizsgálata különböző tenyésztési körülmények} között.

Terveink között szerepelt, hogy valós idejü kvantitatív PCR segítségével megvizsgáljuk az azonosított gének transzkripcióját eltérő környezeti feltételek, illetve tenyésztési körülmények mellett. A vizsgálat során választ kaphatunk arra, melyek azok a specifikus körülmények, amikor a gének átíródása indukálódik és, hogy a vizsgált körülmények esetén van-e különbség a három gén kifejeződése között.

\section{A hmgR gének kópiaszámának emelése és a gének csendesítése.}

A gének izolálását követően, olyan vektorkonstrukciók létrehozását terveztük, melyek a gének túlmüködtetését és a csendesítését teszik lehetővé és így alkalmasak lehetnek a funkció vizsgálatára. A sikeres transzformációt követően megvizsgálhatjuk az 
egyes reduktáz gének szerepét a sejtek növekedésére, a sztatinokkal szembeni érzékenységre és a termelődő karotinoidok és ergoszterin mennyiségi változására.

\section{Az egyes HmgR fehérjék sejten belüli lokalizációját.}

További terveink között szerepelt az egyes reduktáz fehérjék sejten belüli lokalizációjának vizsgálata. Ennek érdekében olyan vektorkonstrukciók létrehozását terveztük, melyekben az egyes reduktáz fehérjék transzmembrán régióját kódoló génszakaszt zöld fluoreszcens fehérje génjével fuzionáltatjuk. Az endoplazmatikus retikulum és a mitokondrium festését követően vizsgálhatóvá válhat ezen organnelumok és a reduktáz fehérjék esetleges kolokalizációja. 


\section{ANYAGOK ÉS MÓDSZEREK}

\subsection{A kísérletek során alkalmazott törzsek}

A transzformációs kísérletek során a Mucor circinelloides f. lusitanicus (CBS 277.49 izolátum) leuA- és pyrG- kétszeres auxotróf mutáns MS12 törzsét (SZMC 12082) alkalmaztuk.

A plazmid klónozási munkákat Escherichia coli TOP10F- törzzsel végeztük.

\subsection{Alkalmazott táptalajok, tápoldatok}

5.2.1. Minimál tápoldat/táptalaj (YNB): $1 \%$ D-glükóz, $0,15 \%\left(\mathrm{NH}_{4}\right)_{2} \mathrm{SO}_{4}, 0,15 \%$ Na-Lglutaminát, 0,05\% YNB (Difco), szükség esetén 0,05\% uracillal vagy 0,05\% leucinnal kiegészítve $(\mathrm{pH} 4,5)$. Szilárd táptalaj előállításához 2\% agart adtunk a tápoldathoz. PEGközvetített protoplaszt transzformáció során a protoplasztokat $0,8 \mathrm{M}$ szorbitolt és $1 \%$ agart tartalmazó YNB fedőagarral összekeverve (pH 3,2) öntöttük 0,8 M szorbitollal kiegészített, 2\% agart tartalmazó YNB táptalajra.

A D-glükózt kísérlettől függően maltózzal, trehalózzal, nátrium-acetáttal, dihidroxiacetonnal helyettesítettük. A sóstressz hatásának vizsgálatához a tápoldatot/táptalajt 1, 2 illetve 3\% nátrium-kloriddal egészítettük ki.

5.2.2. Élesztő-glükóz tápoldat/táptalaj (YEG): $1 \%$ D-glükóz, $0,5 \%$ élesztőkivonat, szilárd táptalaj előállításához $2 \%$ agart adtunk a tápoldathoz.

5.2.3. Élesztő-pepton-glükóz tápoldat/táptalaj (YPG) (pH 4,5): 1\% D-glükóz, 1\% pepton, 0,5\% élesztőkivonat, szilárd táptalaj előállításához 2\% agart adtunk a tápoldathoz. A protoplasztok regeneráltatása során $0,8 \mathrm{M}$ szorbitollal kiegészített YPG tápoldatot alkalmaztunk.

5.2.4. Luria-Bertani tápoldat/táptalaj (LB) $(\mathrm{pH} \mathrm{7,0):1 \%} \mathrm{NaCl}, 1 \%$ tripton, $0,5 \%$ élesztőkivonat, szilárd táptalaj előállításához 2\% agart adtunk a tápoldathoz. A transzformáns törzsek szelekciójához $100 \mu \mathrm{g} / \mathrm{ml}$ ampicillinnel egészítettük ki a tápközeget. 


\subsection{Tenyésztési körülmények}

A gombatörzseket YNB táptalajon (szükség esetén uracillal vagy leucinnal kiegészítve), kéthavonkénti átoltással, $4{ }^{\circ} \mathrm{C}$-on tartottuk fenn. Tenyésztésük általában $25{ }^{\circ} \mathrm{C}$ on, négy napig, állandó megvilágítás mellett történt. Esetenként a hőmérsékletet $\left(20-37{ }^{\circ} \mathrm{C}\right.$ között), a tenyésztési időt (leoltástól számított 4. óra - 4. nap) a kísérleteknek megfelelően változtattuk. Az anaerob tenyésztéseket $\mathrm{BBL}$ GasPak Anaerobic System (Beckton Dickinson) segítségével végeztük. Későbbi felhasználás esetén a táptalajról vagy tápoldatból gyüjtött micéliumot (desztillált vizes mosás után) fagyasztva tároltuk.

Az E. coli törzs tenyésztése ampicillinnel kiegészített $(100 \mu \mathrm{g} / \mathrm{ml}) \quad$ LB tápoldatban/táptalajon történt $37{ }^{\circ} \mathrm{C}$-on egy éjszakán keresztül. Felhasználásig a baktériumsejteket $-70{ }^{\circ} \mathrm{C}$-on tároltuk.

\subsection{Alkalmazott oldatok, pufferek és reagensek}

\subsubsection{Kompetens $E$. coli sejtek készítéséhez felhasznált oldatok}

$100 \mathrm{mM} \mathrm{CaCl} 2$ oldat, hütve tárolva

$70 \%$ glicerin

\subsection{2. $E$. coli sejtek transzformációjához felhasznált oldatok}

TCM puffer: $10 \mathrm{mM}$ Tris (pH 7,5); $10 \mathrm{mM} \mathrm{CaCl}_{2} ; 10 \mathrm{mM} \mathrm{MgCl}_{2}$

Antibiotikum törzsoldat: $50 \mathrm{mg} / \mathrm{ml}$ ampicillin (Sigma) törzsoldat steril desztillált vízben oldva

\subsubsection{DNS gélelektroforézishez használt anyagok}

TAE puffer: $40 \mathrm{mM}$ Tris-ecetsav (pH 7,6); $1 \mathrm{mM} \mathrm{Na} 2 \mathrm{EDTA}$

Agaróz gél: a fragmentum mérettől függően 0,8-2\% agaróz TAE pufferben oldva

Etidium-bromid törzsoldat (Sigma): $10 \mathrm{mg} / \mathrm{ml}$ desztillált vízben oldva

Mintapuffer: 6x DNS mintapuffer (Thermo Scientific)

Molekulasúly marker: $1 \mathrm{~kb}$ DNS marker (Thermo Scientific): steril desztillált víz molekulasúly marker - 6x DNS mintapuffer 4:1:1 arányú keveréke

\subsubsection{Protoplasztképzéshez és PEG-mediált transzformációhoz használt oldatok}

Protoplasztáló oldat: $100 \mathrm{mM}$ nátrium-foszfát puffer; $0,8 \mathrm{M}$ szorbitol; 1,5\% csigaenzim 
Nátrium-foszfát puffer (100 mM): $25 \mathrm{mM} \mathrm{Na}_{2} \mathrm{HPO}_{4} ; 75 \mathrm{mM} \mathrm{NaH}_{2} \mathrm{PO}_{4}$

SMC puffer: $50 \mathrm{mM} \mathrm{CaCl} 2 ; 10 \mathrm{mM}$ MOPS; 0,8 M szorbitol

PMC puffer: 40\% PEG 4000; $10 \mathrm{mM}$ MOPS; 0,6 M szorbitol; $50 \mathrm{mM} \mathrm{CaCl}_{2}$

\subsubsection{Northern hibridizáláshoz használt reagensek}

Tri Reagent (Sigma-Aldrich)

Kloroform (VWR)

Izopropanol (VWR)

Dietil-pirokarbonát (Sigma)

$75 \%$ etanol DEPC kezelt vízzel hígítva

10x MOPS puffer: 200 mM MOPS (pH 7,0); 50 mM nátrium-acetát (pH 5,2); 10 mM EDTA $(\mathrm{pH} \mathrm{8,0)}$

Futtató elegy: 72,2\% DEPC kezelt víz; 10\% 10x MOPS oldat; 17,8\% formaldehid (VWR)

Mintafelvivő puffer: 12,9\% 10x MOPS; 22,6\% formaldehid (Sigma); 64,5\% formamid (Sigma)

TC puffer: $25 \%$ Tris- $\mathrm{HCl}$ (pH 8,0); $40 \%$ glicerol (80\%-os); $1 \%$ brómfenolkék

20x SSC (pH 7,0): $3 \mathrm{M} \mathrm{NaCl} ; 0,3$ trinátrum-citrát

Előhibridizációs puffer: 22,5\% $\mathrm{NaCl}(4 \mathrm{M}) ; 67,5 \%$ DEPC kezelt víz; 10\% SDS (10\%)

Hibridizációs puffer: 22,5\% $\mathrm{NaCl}(4 \mathrm{M}) ; 67,5 \%$ DEPC kezelt víz; 10\% dextrán-szulfát (Sigma); $1 \%$ SDS

Lazac sperma DNS (10 mg/ml, Invitrogen)

Mosó pufferek: $\quad 2 x \mathrm{SSC} ; 0,1 \%$ SDS

$$
0,1 \times \text { SSC; } 0,1 \% \text { SDS }
$$

1. detektáló puffer ( $\mathrm{pH} 7,5): 0,01 \mathrm{M}$ maleinsav; $0,015 \mathrm{M} \mathrm{NaCl}$;

2. detektáló puffer: $1 \%$ blokkoló reagens (Roche) 1. detektáló pufferben

3. detektáló puffer ( $\mathrm{pH}$ 9,5): 0,1 M Tris-HCl; $0,1 \mathrm{M} \mathrm{NaCl} ; 50 \mathrm{mM} \mathrm{MgCl} 2$

Alkalikus foszfát antitest-konjugátum (Anti-Digoxigenin-AP Fab fragments, Roche)

Színreakciós elöhíváshoz: NBT-BCIP törzsoldat (DIG DNA Labeling and Detection Kit, Roche): nitroblue tetrazólium-klorid és 5-bromo-4-kloro-3-indolilfoszfát toluidin só keveréke

\subsubsection{Mitokondrium festéshez használt reagens}

MitoTracker Red FM (Life Technologies) fluoreszcens festéket alkalmaztuk a gyártó utasításainak megfelelően. 


\subsubsection{Endoplazmás retikulum festéshez használt reagens}

Er-Tracker Red (BODIPY TR Glibenclamide (Life Technologies) fluoreszcens festéket alkalmaztuk a gyártó utasításainak megfelelően.

\subsubsection{Apoptózis folyamatainak detektálásához használt reagens}

Apoptosis detection kit-et (Sigma) használtuk a gyártó utasításainak megfelelően.

\subsubsection{Ergoszterin kivonáshoz használt oldatok}

25\% KOH etanol:metanol 2:3 elegyében oldva

\subsubsection{Membránfrakció izolálásához használt oldatok}

Homogenizáló puffer (pH 7.2): 250 mM szacharóz; 1 mM EDTA; 10 mM Tris-HCl

\subsection{Primerek}

A PCR reakciókhoz számos indítószekvenciát terveztünk, melyeket felhasználtunk teljes gének (genomi, illetve cDNS) felszaporításához és szekvenálásához, valamint a valós idejü PCR reakcióknál az egyes gének relatív transzkripciós szintjeinek meghatározásához. Az 1. táblázat tartalmazza a vizsgálatokhoz tervezett indítószekvenciákat.

1. táblázat. A kísérletek során használt indítószekvenciák.

\begin{tabular}{|c|c|c|c|}
\hline Primer & 5'-3' & Termék & $\begin{array}{l}\text { A termék } \\
\text { mérete (bp) }\end{array}$ \\
\hline \multicolumn{4}{|c|}{ A $h m g R$ gének amplifikáláshoz használt indítószekvenciák } \\
\hline $\begin{array}{l}\mathrm{Hmg}-\operatorname{coA} 2 \mathrm{f} \\
\mathrm{Hmg}-\operatorname{coA} 2 \mathrm{r}\end{array}$ & $\begin{array}{l}\text { GGCCTGCAGATGATCAATCTGCTGTCCTAT } \\
\text { TTCGCGGCCGCCTATAAGATGCAATTTCCCGTT }\end{array}$ & $h m g R l$ & $\begin{array}{l}3740(\mathrm{gDNS}) \\
3346(\mathrm{cDNS})\end{array}$ \\
\hline $\begin{array}{l}\text { Hmg-coA3f } \\
\text { Hmg-coA3r }\end{array}$ & 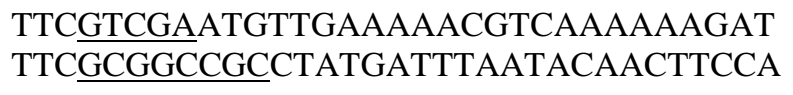 & $h m g R 2$ & $\begin{array}{l}3595(\mathrm{gDNS}) \\
3222(\mathrm{cDNS})\end{array}$ \\
\hline $\begin{array}{l}\text { Hmg-coA4f } \\
\text { Hmg-coA4r }\end{array}$ & $\begin{array}{l}\text { TTCGTCGACATGGCGTCTGCTCTCCCCCATCA } \\
\text { TTC } \underline{\text { GCGGCCGCTTAGGATTTGATGCAGGTT }}\end{array}$ & $h m g R 3$ & $\begin{array}{l}3491(\mathrm{gDNS}) \\
3345(\mathrm{cDNS})\end{array}$ \\
\hline \multicolumn{4}{|c|}{ A qPCR analízishez használt indítószekvenciák } \\
\hline $\begin{array}{l}\text { H1_RT_F } \\
\text { H1_RT_R }\end{array}$ & $\begin{array}{l}\text { CAGAAACAACTCACATGCCTTGCC } \\
\text { TAATAGCTGGAAGTGGATCGTCGG }\end{array}$ & $\begin{array}{l}h m g R 1 \text { gén } \\
\text { egy szakasza }\end{array}$ & 151 \\
\hline $\begin{array}{l}\text { H2_RT_F } \\
\text { H2_RT_R }\end{array}$ & $\begin{array}{l}\text { CTCGTATCATCTGTGCCTCTG } \\
\text { AGCAGTGTTACGGTTGTGAG }\end{array}$ & $\begin{array}{l}\text { hmgR2 gén } \\
\text { egy szakasza }\end{array}$ & 107 \\
\hline $\begin{array}{l}\text { hmgR3_RTf } \\
\text { hmgR3_RTr }\end{array}$ & $\begin{array}{l}\text { GAATCCAGTCTGTTGCCTCTCCA } \\
\text { GAGTCACCGTCAATGTTCATGGGA }\end{array}$ & $\begin{array}{l}\text { hmgR3 gén } \\
\text { egy szakasza }\end{array}$ & 128 \\
\hline $\begin{array}{l}\text { MCactinF } \\
\text { MCactinR }\end{array}$ & $\begin{array}{l}\text { CACTCCTTCACTACCACCGCTGA } \\
\text { GAGAGCAGAGGATTGAGCAGCAG }\end{array}$ & $\begin{array}{l}\text { aktin gén egy } \\
\text { szakasza }\end{array}$ & 117 \\
\hline
\end{tabular}




\begin{tabular}{|c|c|c|c|}
\hline Primer & 5'-3' & Termék & $\begin{array}{c}\text { A termék } \\
\text { mérete (bp) }\end{array}$ \\
\hline \multicolumn{4}{|c|}{ A bejutatott plazmidok kimutatására használt indítószekvenciák } \\
\hline Gpdp & CATGAAGTGTGAGACATTGCGA & gpdP 3' vége & \\
\hline png1rev & TGTTGTCTCGATTGAATGGCTGG & $\begin{array}{l}h m g R l \text { gén } 5 \\
\quad \text { vége }\end{array}$ & 656 \\
\hline png2rev & TCCACAGGATTGGCGGTCTAT & $\begin{array}{l}h m g R 2 \text { gén } 5 \\
\text { vége }\end{array}$ & 869 \\
\hline png3rev & CAGCGTGTGGTCAATGGTGTT & $\begin{array}{l}h m g R 3 \text { gén } 5 \\
\text { vége }\end{array}$ & 538 \\
\hline \multicolumn{4}{|c|}{ A géncsendesítéshez és a Northern hibridizációhoz használt indítószekvenciák } \\
\hline $\begin{array}{l}\mathrm{H} 1 \mathrm{CSf} \\
\mathrm{H} 1 \mathrm{CSr}\end{array}$ & $\begin{array}{l}\text { TTCGCGGCCGCTCACTGGCTTCATGAACCGGCT } \\
\text { CCGCTCGAGAGCAATGTTCTTCATAATCCGAA }\end{array}$ & $\begin{array}{l}h m g R l \text { gén } \\
\text { egy szakasza }\end{array}$ & 662 \\
\hline $\begin{array}{l}\mathrm{H} 2 \mathrm{CSf} \\
\mathrm{H} 2 \mathrm{CSr}\end{array}$ & $\begin{array}{l}\text { TTCGCGGCCGCAGATAACCCGTTCCGATATTTG } \\
\text { CCGCTCGAGTCATTGTCATGTAGTTTGGTTGT }\end{array}$ & $\begin{array}{l}h m g R 2 \text { gén } \\
\text { egy szakasza }\end{array}$ & 626 \\
\hline $\begin{array}{l}\mathrm{H} 3 \mathrm{CSf} \\
\mathrm{H} 3 \mathrm{CSr}\end{array}$ & $\begin{array}{l}\text { TTCGCGGCCGCTCCAGCGTCTTTGGCAAAGGCA } \\
\text { TTCETCGAGGGTGTCCCGTGTTGGAGAGCGAC }\end{array}$ & $\begin{array}{l}h m g R 3 \text { gén } \\
\text { egy szakasza }\end{array}$ & 697 \\
\hline \multicolumn{4}{|c|}{ A fehérjék lokalizációjának vizsgálata során használt indítószekvenciák } \\
\hline $\begin{array}{l}\text { GFPh1c1 } \\
\text { GFPh1c2 }\end{array}$ & $\begin{array}{l}\text { TTAGCTAGCCGTGAGCAAGGGCGAGGAGCT } \\
\text { TTAECGGCCGCTTACTTGTACAGCTCGTCCA }\end{array}$ & $\begin{array}{l}\text { gfp a } h m g R l- \\
\text { hez }\end{array}$ & \\
\hline $\begin{array}{l}\text { GFPh2c1 } \\
\text { GFPh2c2 }\end{array}$ & $\begin{array}{l}\text { CGCGAATTCGTGAGCAAGGGCGAGGAGCT } \\
\text { TTAGCGGCCGCTTACTTGTACAGCTCGTCCA }\end{array}$ & $\begin{array}{l}\text { gfp a } h m g R 2- \\
\text { höz }\end{array}$ & $717 \mathrm{bp}$ \\
\hline $\begin{array}{l}\text { GFPh3c1 } \\
\text { GFPh3c2 }\end{array}$ & $\begin{array}{l}\text { GCGGAATTCGTGAGCAAGGGCGAGGAGCT } \\
\text { TTAGCGGCCGCTTACTTGTACAGCTCGTCCA }\end{array}$ & $\begin{array}{l}\text { gfp a } h m g R 3- \\
\text { hoz }\end{array}$ & \\
\hline \multicolumn{4}{|c|}{ Az egyes $h m g R$ gének cDNS-einek szekvenáltatásához használt indítószekvenciák } \\
\hline $\begin{array}{l}\text { H1cDNS1 } \\
\text { H1cDNS2 } \\
\text { H1cDNS3 } \\
\text { H1cDNS4 } \\
\text { H1cDNS5 } \\
\text { H1cDNS6 } \\
\text { H1cDNS7 } \\
\text { H1cDNS8 }\end{array}$ & $\begin{array}{l}\text { ATGATCAATCTGCTGTCCTATAAATC } \\
\text { AGGTGCGCCCAATTTATACACGGTG } \\
\text { TACTCTAGCAACCACTATCTTCATG } \\
\text { ATAGCGACCACCCATTTGCTGATGAC } \\
\text { GTGAAAAGCTTGCTAGCCGAGATCT } \\
\text { GAAATCATGTTCATGCCCATTGCGTC } \\
\text { CAGGTAGCAATGGCCGGCAAGCTGC } \\
\text { CTATAAGATGCAATTTCCCGTTACAG }\end{array}$ & $h m g R l \mathrm{cDNS}$ & \\
\hline $\begin{array}{l}\text { H2cDNS1 } \\
\text { H2cDNS2 } \\
\text { H2cDNS3 } \\
\text { H2cDNS4 } \\
\text { H2cDNS5 } \\
\text { H2cDNS6 } \\
\text { H2cDNS7 } \\
\text { H2cDNS8 }\end{array}$ & $\begin{array}{l}\text { ATGTTGAAAAACGTCAAAAAAGAT } \\
\text { CAAGTAACAGGGCGGGTGTGATGTTG } \\
\text { GGCATATGTGCGCTTGTGTTTGGCC } \\
\text { GCTGCTTTGCTACATTGAACAGATAG } \\
\text { GTTATATCCAAATGGCTGACTATCGCT } \\
\text { GATTTGCATATCGGGATATCTCTCTG } \\
\text { CATTCAACTCGACCTCTCGTTTTGCTCG } \\
\text { CTATGATTTAATACAACTTCCAGGA }\end{array}$ & $h m g R 2 \mathrm{cDNS}$ & \\
\hline $\begin{array}{l}\text { H3cDNS1 } \\
\text { H3cDNS2 } \\
\text { H3cDNS3 } \\
\text { H3cDNS4 } \\
\text { H3cDNS5 } \\
\text { H3cDNS6 } \\
\text { H3cDNS7 } \\
\text { H3cDNS8 }\end{array}$ & $\begin{array}{l}\text { ATGGCGTCTGCTCTCCCCCATCAT } \\
\text { GTTCATGTACAAGGACACGAAGGT } \\
\text { CATGGCAGACAACATTGACATTATC } \\
\text { GATGGCCTTGTACGAGGAGGATGCA } \\
\text { GACATGGGACACTTGCCTCTGTTGGT } \\
\text { CAGCCGTGATGATTTCAGCGCCATCT } \\
\text { CTTGTGTGGAATTCCCTTCCATCAT } \\
\text { TTAGGATTTGATGCAGGTTCCAGGA } \\
\end{array}$ & $h m g R 3 \mathrm{cDNS}$ & \\
\hline
\end{tabular}




\subsection{Alkalmazott plazmidok}

A kísérleteinkhez különböző transzformációs vektorokat hoztunk létre, melyeket a M. circinelloides MS12 leucin/uracil kettős auxotróf törzsbe jutattunk be (2. táblázat). A transzformációs vektorok mindegyike tartalmazza a Mucor gpdl (glicerinaldehid-3-foszfát dehidrogenáz gén (EMBL azonosító: AJ293012) promóter és terminális (gpdlP és gpd1T) régióját. Ez által biztosítottuk a kifejeztetni kívánt gének megfelelő expresszióját. A szabályozó régiókon kívül mindegyik vektor tartalmazta az orotidin-5-foszfát-dekarboxilázt kódoló és az uracil auxotrófiát komplementáló, pyrG gént (Benito és mtsi. 1992), melyet szelekciós markerként alkalmaztunk. A vektorok építéséhez a korábbi munkák során létrehozott pPT43 és pPT81 (Papp és mtsi. 2006) vektorokat használtuk. A pPT43 hordozza a Mucor gpdT és $g p d P$ szabályozó régiókat, a pPT81 ezen szabályozó régiókon kívül tartalmazza a pyrG gént is.

A $h m g R$ gének cDNS szekvenciájának meghatározásához és a génklónozási munkákhoz a pJET1.2 (Thermo Scientific) vektort alkalmaztuk. A gfp gén felszaporításához a laborunkban korábban létrehozott pPT43/gfp vektort használtuk.

2. táblázat. A kísérletek során felhasznált és létrehozott plazmidok és főbb tulajdonságaik.

Plazmid Leírás (zárójelben a szelekciós markerek)

\section{Génklónozáshoz alkalmazott plazmidok}

pJET $1.2 \quad$ Klónozó vektor (Amp)

\section{A hmgR gének túlmüködtetéséhez alkalmazott plazmidok}

pPT43

Mucor gpdP és gpdT (Amp)

pPT81

Mucor gpdP és gpdT (Amp és $p y r G$ )

pNG1

Expressziós kazetta; Mucor $g p d P, h m g R l, g p d T$ (Amp és $p y r G$ )

pNG2

Expressziós kazetta; Mucor gpdP, hmgR2, gpdT (Amp és pyrG)

pNG3

Expressziós kazetta; Mucor gpdP, hmgR3, gpdT (Amp és pyrG)

\section{A hmgR gének csendesítésére használt vektorok}

pAS1

A $h m g R 15$ ' régiójából 662 nukleotidot tartalmazó részt hordoz, fordított orientációban a pPT43 gpdP és $g p d T$ közé építve (Amp és $p y r G$ )

pAS2

A $h m g R 2$ 5' régiójából egy 662 nukleotidot tartalmazó részt hordoz, fordított orientációban a pPT43 gpdP és $g p d T$ közé építve (Amp és $p y r G$ )

A $h m g R 3$ 5' régiójából egy 662 nukleotidot tartalmazó részt hordoz, fordított orientációban a pPT43 gpdP és $g p d T$ közé építve (Amp és pyrG) 


\begin{tabular}{|c|c|}
\hline Plazmid & Leírás (zárójelben a szelekciós markerek) \\
\hline \multicolumn{2}{|c|}{ A fehérjék sejten belüli lokalizációjának vizsgálatához alkalmazott plazmidok } \\
\hline pPT43/gfp & A $g f p$ gén $g p d P$ és $g p d T$ közé építve (Amp és $p y r G)$ \\
\hline pH1cGFP & $\begin{array}{l}\text { A pNG1 plazmidban található } h m g R l \text { gén transzmembrán régiót kódoló } \\
\text { génszakaszának fúziója } g f p \text {-vel (Amp és } p y r G)\end{array}$ \\
\hline $\mathrm{pH} 2 \mathrm{cGFP}$ & $\begin{array}{c}\text { A pNG2 plazmidban található } h m g R 2 \text { gén transzmembrán régiót kódoló } \\
\text { génszakaszának fúziója } g f p \text {-vel (Amp és } p y r G)\end{array}$ \\
\hline pH3cGFP & $\begin{array}{c}\text { A pNG3 plazmidban található } h m g R 3 \text { gén transzmembrán régiót kódoló } \\
\text { génszakaszának fúziója } g f p \text {-vel (Amp és } p y r G)\end{array}$ \\
\hline
\end{tabular}

\subsection{Vizsgálati módszerek}

\subsubsection{Genomi DNS kivonása $M$. circinelloides-ből}

A genomi DNS kivonást MasterPure Yeast DNA purification kittel (Epicentre) végeztük a gyártó utasításait követve.

\subsubsection{DNS/RNS gélelektroforézis}

A nukleinsav mintákhoz mintapuffert adtunk, majd a várt fragmentumok és a gél méretétől, illetve a kísérlettől függően $0,8-2 \%$ agaróz gélben, $80-110 \mathrm{~V}$ feszültséggel, 1-4 órán keresztül végeztük az elválasztást. Mind az agaróz gél készítéséhez, mind futtatópuffernek TAE puffert használtunk. A nukleinsavakat etídium-bromidos festéssel $(0,5$ $\mu \mathrm{g} / \mathrm{ml}$ ), UV fény alatt detektáltuk. A fragmentumok méretének meghatározásához különböző molekulasúly markereket használtunk.

\subsubsection{RNS gélelektroforézis Northern hibridizációhoz}

A nukleinsav mintákhoz mintapuffert adtunk, majd 1,2\% agaróz gélben $110 \mathrm{~V}$ feszültséggel 2-2,5 órán keresztül végeztük az elválasztást. Az agaróz gél készítéséhez 10x MOPS oldatot és DEPC kezelt vizet használtunk. Az agarózzal történő forralás után lehütöttük a gélt $60{ }^{\circ} \mathrm{C}$-ra és formaldehidet adtunk hozzá.

\subsubsection{DNS visszaizolálása agaróz gélből}

A visszaizolálni kívánt DNS fragmentumokat tartalmazó gélrészletet steril szikével UV lámpa alatt vágtuk ki a 0,8\% agarózt tartalmazó gélből. A DNS-t a DNA Extraction Kit 
(Thermo Scientific) vagy a Zymoclean Large fragment DNA Recovery Kit (ZymoResearch) segítségével nyertük ki a gyártó utasításainak megfelelően.

\subsubsection{RNS tisztítása $M$. circinelloides-ből}

Az RNS tisztítását E.Z.N.A Total RNA Kit II-vel (OmegaBiotek) végeztük a gyártó utasításait követve. A Northern hibridizációhoz az RNS tisztítást Tri-reagenssel (Sigma) végeztük a gyártó utasításait követve.

\subsection{6. cDNS szintézis (reverz transzkripció)}

Az RNS mintákat DNáz-zal (ThermoScientific) kezeltük, a gyártó utasításai szerint:

$1 \mu \mathrm{g}$ RNS

1x reakciópuffer $\left(2,5 \mathrm{mM} \mathrm{MgCl}_{2}\right.$-dal $)$

1U RNáz inhibítor (Thermo Scientific)

1U DNáz

A reakciót 30 percig $37{ }^{\circ} \mathrm{C}$-on végeztük, majd 5 mM EDTA-val $65^{\circ} \mathrm{C}$-on történő 10 perces kezeléssel állítottuk le. Minden minta esetében PCR, illetve qPCR reakciók segítségével ellenőriztük a minták DNS mentességét.

A DNáz kezelt RNS mintákból a reverz transzkripciót Maxima H Minus First Strand cDNA Synthesis Kit (Thermo Scientific) segítségével végeztük el. A reakcióhoz oligo(dT)18 és random hexamer primereket használtunk a gyártó utasítása szerint.

\subsubsection{Alkalmazott PCR technikák és reakciókörülmények}

Kísérleteink során különböző PCR technikákat alkalmaztunk. A PCR reakciókat T3 Thermocycler (Biometra) készülékben végeztük, a real-time PCR esetében C1000 Thermal Cycler készüléket és CFX96 Real-Time System (Bio-Rad) detektáló rendszert használtunk.

\subsubsection{A $h m g R$ gének amplifikálásához használt reakciókörülmények}

A gének genomi DNS-ből történő amplifikálásához a Long PCR Enzim Mix-et (Thermo Scientific) használtuk a gyártó ajánlásai szerint. A reakciókat $25 \mu$ végtérfogatban mértük össze a következök szerint:

20-50 ng genomi DNS

0,4-0,4 $\mu \mathrm{M}$ specifikus primer (1. táblázat)

$0,2 \mathrm{mM}$ dNTP mix 
1x Long PCR puffer (1,5 mM $\mathrm{MgCl}_{2}$-vel kiegészítve)

1,25U Long PCR Enzim Mix

Az amplifikálás körülményei a $h m g R l$ gén esetében:

\begin{tabular}{|c|c|c|c|}
\hline $95^{\circ} \mathrm{C}$ & 3 perc & 1 ciklus & elődenaturálás \\
\hline $95^{\circ} \mathrm{C}$ & 1 perc & & denaturálás \\
\hline $60^{\circ} \mathrm{C}$ & 1 perc & 30 ciklus & primer kötődés \\
\hline $72^{\circ} \mathrm{C}$ & 5 perc & & láncszintézis \\
\hline $72^{\circ} \mathrm{C}$ & 10 perc & 1 ciklus & végső láncszintézis \\
\hline
\end{tabular}

Az amplifikálás körülményei a $h m g R 2$ gén esetében:

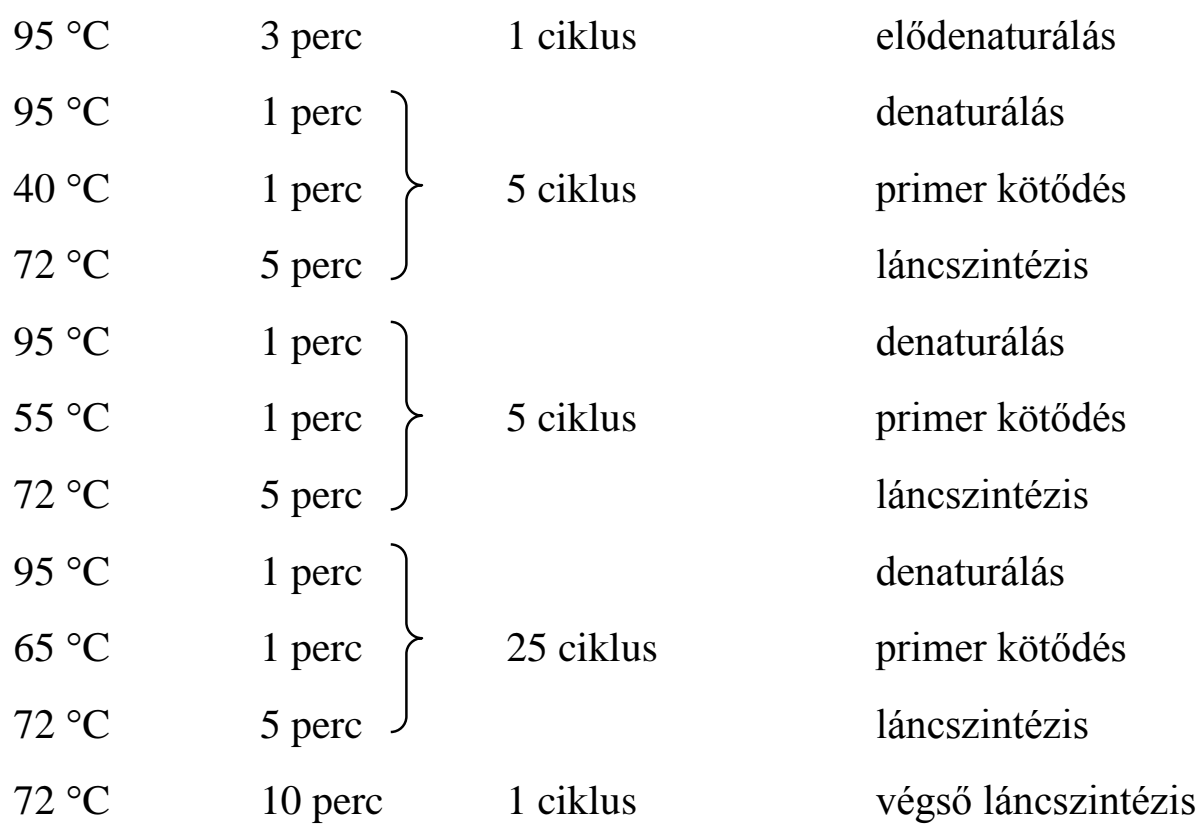

Az amplifikálás körülményei a $h m g R 3$ gén esetében:

\begin{tabular}{|c|c|c|c|}
\hline $95^{\circ} \mathrm{C}$ & 3 perc & 1 ciklus & elődenaturálás \\
\hline $95^{\circ} \mathrm{C}$ & 1 perc & & denaturálás \\
\hline $45^{\circ} \mathrm{C}$ & 1 perc & 5 ciklus & primer bekötődés \\
\hline $72{ }^{\circ} \mathrm{C}$ & 5 perc & & láncszintézis \\
\hline $95^{\circ} \mathrm{C}$ & 1 perc & & denaturálás \\
\hline $58{ }^{\circ} \mathrm{C}$ & 1 perc & 5 ciklus & primer bekötődés \\
\hline $72{ }^{\circ} \mathrm{C}$ & 5 perc & & láncszintézis \\
\hline
\end{tabular}




\begin{tabular}{|c|c|c|c|}
\hline $95^{\circ} \mathrm{C}$ & 1 perc & & denaturálás \\
\hline $68^{\circ} \mathrm{C}$ & 1 perc & 25 ciklus & primer bekötődés \\
\hline $72{ }^{\circ} \mathrm{C}$ & 5 perc & & láncszintézis \\
\hline $72{ }^{\circ} \mathrm{C}$ & 10 perc & & végső láncszintézis \\
\hline
\end{tabular}

\subsubsection{A $h m g R$ gének cDNS amplifikálásához használt reakció körülmények}

A reverz transzkripciót követően a teljes cDNS-böl történő amplifikáláshoz Phusion High-Fidelity DNS Polimerázt (Thermo Scientific) használtunk a gyártó utasításainak megfelelően. A reakciókat $50 \mu l$ végtérfogatban mértük össze a következők szerint:

20-50 ng cDNS (reverz transzkripciót követően)

0,5-0,5 $\mu \mathrm{M}$ specifikus primer (1. táblázat)

$200 \mu \mathrm{M}$ dNTP mix

1x Phusion HF vagy GC puffer (1,5 $\mathrm{mM} \mathrm{MgCl} 2$-vel kiegészítve)

$1 \mathrm{U}$ Phusion High-Fidelity DNS Polimeráz

Az amplifikálás körülményei a $h m g R l$ és $h m g R 2$ esetében:

\begin{tabular}{|c|c|c|c|}
\hline $95^{\circ} \mathrm{C}$ & 3 perc & 1 ciklus & elődenaturálás \\
\hline $95^{\circ} \mathrm{C}$ & 0,5 perc & & denaturálás \\
\hline $55^{\circ} \mathrm{C}$ & 1 perc & 30 ciklus & primer kötődés \\
\hline $72^{\circ} \mathrm{C}$ & 3,4 perc & & láncszintézis \\
\hline $72^{\circ} \mathrm{C}$ & 7 perc & 1 ciklus & végső láncszintézis \\
\hline
\end{tabular}

Az amplifikálás körülményei a $h m g R 3$ esetében:

\begin{tabular}{|c|c|c|c|}
\hline $95^{\circ} \mathrm{C}$ & 3 perc & 1 ciklus & elődenaturálás \\
\hline $95^{\circ} \mathrm{C}$ & 0,5 perc & & denaturálás \\
\hline $60^{\circ} \mathrm{C}$ & 1 perc & 30 ciklus & primer kötődés \\
\hline $72{ }^{\circ} \mathrm{C}$ & 3 perc & & láncszintézis \\
\hline $72{ }^{\circ} \mathrm{C}$ & 7 perc & 1 ciklus & végső láncszintézis \\
\hline
\end{tabular}


5.7.7.3. A gének csendesítését lehetővé tevő génszakaszok amplifikálásához használt reakciókörülmények

A gének csendesítéséhez a korábban létrehozott pNG vektorokat alkalmaztuk. A PCR reakciók során Taq DNS Polimerázt (Zenon) használtunk a gyártó utasításainak megfelelöen. A reakciót $25 \mu$ l végtérfogatban mértük össze a következők szerint:

20-50 ng plazmid DNS

0,5-0,5 $\mu \mathrm{M}$ specifikus primer (1. táblázat)

$200 \mu \mathrm{M}$ dNTP mix

10x Taq puffer

2,5 $\mathrm{mM} \mathrm{MgCl} 2$

2U Taq DNS Polimeráz

Az amplifikálás körülményei:

\begin{tabular}{|c|c|c|c|}
\hline $95^{\circ} \mathrm{C}$ & 3 perc & 1 ciklus & elődenaturálás \\
\hline $95^{\circ} \mathrm{C}$ & 0,5 perc & & denaturálás \\
\hline $60{ }^{\circ} \mathrm{C}$ & 1 perc & 30 ciklus & primer kötődés \\
\hline $72{ }^{\circ} \mathrm{C}$ & 0,5 perc & & láncszintézis \\
\hline $72{ }^{\circ} \mathrm{C}$ & 7 perc & 1 ciklus & végső láncszintézis \\
\hline
\end{tabular}

\subsubsection{A jelölt hibridizációs próba készítéséhez használt reakciókörülmények}

A génpróba készítéséhez templátként a laborunkban korábban létrehozott pAS vektorokat használtuk. A reakciókat PCR DIG Probe Synthesis Kit (Roche) segítségével állítottuk össze $25 \mu$ l-es végtérfogatba a következők szerint:

20-50 ng plazmid DNS

$1 \mu \mathrm{M}-1 \mu \mathrm{M}$ specifikus primer (1. táblázat)

0,1 mM dNTP mix (Thermo Scientific)

0,1 mM PCR DIG mix (DIG-11-dUTP-t tartalmaz, Roche)

1x Expand High Fidelity puffer (1,5 $\mathrm{mM} \mathrm{MgCl} 2$-dal kiegészítve)

2U Expand High Fidelity enzim

Az amplifikálás körülményei:
$95{ }^{\circ} \mathrm{C}$
3 perc
1 ciklus
elődenaturálás 


$\left.\begin{array}{ll}95^{\circ} \mathrm{C} & 0,5 \text { perc } \\ 60{ }^{\circ} \mathrm{C} & 1 \text { perc } \\ 72{ }^{\circ} \mathrm{C} & 0,5 \text { perc }\end{array}\right\} \begin{aligned} & \text { denaturálás } \\ & 70 \text { ciklus } \\ & 72^{\circ} \mathrm{C}\end{aligned} \begin{aligned} & 7 \text { perc } \\ & 1 \text { ciklus }\end{aligned}$

\subsubsection{A gfp gén amplifikálásához használt reakciókörülmények}

A gfp gén amplifikálásához a laborunkban korábban létrehozott pPT43/gfp vektort használtuk. A PCR reakció során Phusion High-Fidelity DNS Polimerázt (Thermo Scientific) használtunk a gyártó utasításainak megfelelően. A reakciót $25 \mu l$ végtérfogatban mértük össze a következők szerint:
20-50 ng plazmid DNS
$0,5-0,5 \mu \mathrm{M}$ specifikus primer (1. táblázat)
$200 \mu \mathrm{M}$ dNTP mix
1x Phusion HF puffer (1,5 $\mathrm{mM} \mathrm{MgCl}_{2}$-vel kiegészítve)
1U Phusion High-Fidelity DNS Polimeráz

Az amplifikálás körülményei:

\begin{tabular}{|c|c|c|c|}
\hline $95^{\circ} \mathrm{C}$ & 3 perc & 1 ciklus & elődenaturálás \\
\hline $95^{\circ} \mathrm{C}$ & 0,5 perc & & denaturálás \\
\hline $60{ }^{\circ} \mathrm{C}$ & 1 perc & 30 ciklus & primer kötődés \\
\hline $72{ }^{\circ} \mathrm{C}$ & 0,5 perc & & láncszintézis \\
\hline $72{ }^{\circ} \mathrm{C}$ & 7 perc & 1 ciklus & végső láncszintézis \\
\hline
\end{tabular}

5.7.7.6. Valós idejü PCR reakciók a kópiaszám, valamint a transzkripciós szintek meghatározásához

A méréseket monosporangiális telepekből izolált DNS-ből, illetve RNS-ből reverz transzkripcióval előállított cDNS-ből végeztük el. A reakciókat Maxima SYBR Green qPCR Master Mix (Thermo Scientific) segítségével mértük össze. A nyert eredményeket a $2^{-\Delta \Delta \mathrm{Ct}}$ módszer segítségével értékeltük ki (Livak és Schmittgen 2001).

A reakciók összemérése $20 \mu$ l végtérfogatban történt 96 lyukú lemezeken:

20-50 ng DNS vagy cDNS

$0,4 \mu \mathrm{M}-0,4 \mu \mathrm{M}$ specifikus primer (1. táblázat)

1x Maxima SYBR Green qPCR Master Mix 


\begin{tabular}{|c|c|c|c|}
\hline $95^{\circ} \mathrm{C}$ & 3 perc & 1 ciklus kezdeti & denaturáció \\
\hline $95^{\circ} \mathrm{C}$ & 1 perc & & denaturáció \\
\hline $60^{\circ} \mathrm{C}$ & 0,5 perc & 40 ciklus & primerkötődés \\
\hline $72^{\circ} \mathrm{C}$ & 0,5 perc & & láncszintézis \\
\hline
\end{tabular}

Melting curve analízis:

$55^{\circ} \mathrm{C}-95{ }^{\circ} \mathrm{C} \quad 10$ másodperc $0,5^{\circ} \mathrm{C}$-onként emelkedő hőmérséklet

5.7.7.7. A $h m g R$ gének túlmüködtetését lehetővé tevő vektorok kimutatására használt PCR reakció:

A $h m g R$ gének túlmüködtetéshez használt vektorok kimutatásához Taq DNS polimerázt (Zenon) alkalmaztunk. A reakciókat $25 \mu$ végtérfogatban mértük össze a következő szerint:

$$
\begin{aligned}
& \text { 20-50 ng genomi DNS } \\
& \text { 0,4-0,4 } \mu \mathrm{M} \text { specifikus primer (1. táblázat) } \\
& 0,4 \mathrm{mM} \text { dNTP mix } \\
& \text { 1x Dupla-Taq puffer } \\
& 2,5 \mathrm{mM} \mathrm{MgCl}_{2} \\
& 2 \text { U Dupla-Taq DNA Polymerase }
\end{aligned}
$$

\begin{tabular}{|c|c|c|c|}
\hline $95^{\circ} \mathrm{C}$ & 3 perc & 1 ciklus & elődenaturáció \\
\hline $95^{\circ} \mathrm{C}$ & 1perc & & denaturáció \\
\hline $58^{\circ} \mathrm{C}$ & 1perc & 30 ciklus & primerkötődés \\
\hline $72{ }^{\circ} \mathrm{C}$ & 5 perc & & láncszintázis \\
\hline $72^{\circ} \mathrm{C}$ & 10perc & 1 ciklus & végső láncszintázis \\
\hline
\end{tabular}

az amplifikálás körülményei:

\subsubsection{Génklónozás során alkalmazott módszerek, plazmidkonstrukciók létrehozása}

\subsubsection{Restrikciós emésztések, ligálás}

A restrikciós emésztéseket, ligálásokat az általánosan használt módszerek szerint végeztük (Sambrook és mtsi. 1989) követve a gyártók utasításait, valamint optimalizálva az adott kísérleti körülményekhez. A DNS fragmentumokat a CloneJet PCR cloning Kit-ben 
található pJET1.2 (Thermo Scientific) klónozó vektorba építettük a gyártó utasításait követve.

\subsubsection{Plazmid DNS tisztítása}

Plazmid DNS tisztításához a Viogene Mini-M Plasmid DNA Extraction System (Viogene), nagyobb mennyiségü plazmid DNS tisztításához a Viogene Midi-V100 Plasmid DNA Extraction System (Viogene) kiteket használtuk a gyártó utasításai szerint.

\subsubsection{Northern hibridizálás}

Az RNS minták izolálását követően az RNS integritás ellenőrzése céljából a mintákat 2\% agart tartalmazó gélben megfuttattuk. A felületek és a futtatókádak 10\% $\mathrm{H}_{2} \mathrm{O}_{2}$-dal történő RNáz mentesítése után az RNS mintákat denaturáló formaldehid-agaróz gélelektroforézissel elválasztottuk. A mintákat $96 \%$ etanolban kicsaptuk ( 2 óra, $-70{ }^{\circ} \mathrm{C}$, majd centrifugálás (15.000 g, 10 perc) után DEPC kezelt desztillált vízbe vettük fel. 20-25 $\mu \mathrm{g}$ RNS-t $6 \mu$ l desztillált vízbe feloldottunk és 19,4 $\mu$ l mintafelvivő puffert adtunk hozzá. A mintákat $65{ }^{\circ} \mathrm{C}$-on 10 percig, majd jégen 10 percig inkubáltuk. Az inkubálást követően 2,5 $\mu 1$ TC puffert adtunk hozzá. A mintákat 1\% MOPS és 17,8\% formaldehidet tartalmazó pufferben futtattuk. Az elválasztott RNS-t, 20x SSC-t használva blottoló pufferként, kapilláris transzferrel átvittük a hibridizációs membránra. Hibridizációs membránként Amersham Hybond-N ${ }^{+}$(GE Healthcare) membránt alkalmaztunk.

A hibridizációs membránt legalább két órán át $65^{\circ} \mathrm{C}$-on előhibridizációs pufferrel, majd 16 órán át $65{ }^{\circ} \mathrm{C}$-on, jelölt próbát tartalmazó hibridizációs oldattal hibridizáltuk. Az elöhibridizációs oldatot $(20 \mathrm{ml}) 100 \mu \mathrm{l}$, míg a hibridizációs oldatot $50 \mu \mathrm{l}$ lazac spermaDNSsel $(10 \mu \mathrm{g} / \mathrm{ml})$ egészítettük ki. A próba jelöléséhez minden esetben digoxigenin jelölést alkalmaztunk (PCR DIG Probe Synthesis Kit, Roche). A lazac sperma DNS-t és a jelölt próbát minden esetben 10 percig $100{ }^{\circ} \mathrm{C}$-os, majd 10 percig $4{ }^{\circ} \mathrm{C}$-os inkubációval denaturáltuk.

A hibridizálást követően a membránt szobahőmérsékleten kétszer 5 percig 2x SSC, $0,1 \%$ SDS oldattal, majd kétszer 15 percig $65{ }^{\circ} \mathrm{C}$-on $0,1 \times$ SSC, $0,1 \%$ SDS oldattal mostuk. Ezt követően 1. detektáló pufferrel 1 percig, majd 2. detektáló pufferrel 30 percig, majd a 2. detektáló pufferhez adott $4 \mu \mathrm{l}$ alkalikus foszfatáz antitest-konjugátummal (AntiDigoxygenin-AP, Roche) újabb 30 percig inkubáltuk szobahőmérsékleten. Ezt követően kétszer 15 perces mosás következett 1 . detektáló pufferrel, majd 2-5 perces mosás 3. 
detektáló pufferrel. A detektálást a 3. detektáló pufferhez adott $200 \mu$ NBT-BCIP (DIG DNA Labeling and Detection Kit, Roche) elöhívó reagenssel végeztük, sötétben történő 1-2 órás inkubációval. Végül a felesleges festéket desztillált vízzel lemostuk a membránról.

\subsubsection{A feltételezett HMG-KoA reduktáz szekvenciák analíziséhez használt szoftverek}

A feltételezett HmgR fehérjék szekvenciájának elemzéséhez a Swiss Expasy Server (http://www.expasy.ch) programjait használtuk. A molekulatömeg és az izoelektromos pont (pI) meghatározásához a ProtParam (Gasteiger és mtsi. 2005), a transzmembrán domének kereséséhez pedig a HMMTOP (Tusnády és Simon 2001) és TMPred (Hofmann és Stoffel 1993) programokat használtuk. A fehérjékben található motívumok és domének keresését a Motif Scan (MyHits) program (Pagni és mtsi. 2007) segítségével végeztük. A szekvenciák elemzése során a szoftverek alap beállításait használtuk.

\subsubsection{Kompetens $E$. coli sejtek készítése}

E.coli $\mathrm{TOP}_{10 \mathrm{~F}^{-}} 16$ órán át nevelt tenyészet $1 \mathrm{ml}$-ét $30 \mathrm{ml} \mathrm{LB}$ tápoldatba átoltva, a baktériumokat $\mathrm{OD}_{660}=0,5$ érték eléréséig $37^{\circ} \mathrm{C}$-on, $200 \mathrm{rpm}$ rázatás mellett növesztettük. A tenyészetet centrifugáltuk ( $2162 \mathrm{~g}, 10$ perc, $\left.4{ }^{\circ} \mathrm{C}\right)$, majd a sejteket, az átoltott tenyészettel 11 arányban, hideg $100 \mathrm{mM}$-os $\mathrm{CaCl}_{2}$ oldatban felszuszpendáltuk. Centrifugálást (2162 g, 10 perc, $4^{\circ} \mathrm{C}$ ) követően a lépést megismételtük, majd 1 órán át tartó jeges vízfürdőben történő inkubációt követően ismét centrifugáltuk a sejteket $\left(2162 \mathrm{~g}, 10\right.$ perc, $\left.4{ }^{\circ} \mathrm{C}\right)$. A kiülepedett sejteket 1/20 térfogatú hideg, $20 \%$ glicerin tartalmú $100 \mathrm{mM} \mathrm{CaCl} 2$ oldatban felszuszpendáltuk. A kompetens sejteket $100 \mu$ mennyiségekbe szétadagoltuk, ezeket a későbbi felhasználásig $-70^{\circ} \mathrm{C}$-on tároltuk.

\subsubsection{Baktérium transzformáció}

$100 \mu \mathrm{l}$ fagyasztva tárolt kompetens sejtet jégen felolvasztottunk, majd 15-25 $\mu \mathrm{l}$ ligátumot és $100 \mu \mathrm{l}$ TCM puffert adtunk hozzá és a baktériumokat 30 percig jégen inkubáltuk. Ezt követően 1 perc 30 másodpercre $42{ }^{\circ} \mathrm{C}$-ra helyeztük, majd 10 percig szobahőmérsékleten inkubáltuk. A baktériumokat végül ampicillin tartalmú (100 $\mu \mathrm{g} / \mathrm{ml}) \mathrm{LB}$ táptalajra szélesztettük. A Petri-csészéket 16 órán keresztül $37^{\circ} \mathrm{C}$-on inkubáltuk. 


\subsubsection{Protoplasztképzés}

A $M$. circinelloides protoplasztok képzéséhez a sejtek előkészítését celofánon történő előneveléssel végeztük el. Az MS12 törzs YNB táptalajon, 4-5 napon keresztül, fényben nevelt tenyészetéről steril desztillált vízzel lemostuk a sporangiospórákat, majd a tömény spóraszuszpenzióból oltótűvel friss, celofánkoronggal fedett YEG táptalajra oltottunk. A tenyészeteket $25^{\circ} \mathrm{C}$-on, 16 órán keresztül neveltük. 16 óra elteltével a micéliumkorongokat protoplasztáló oldatba helyeztük, majd 3 órán át, szobahőmérsékleten, $50 \mathrm{rpm}$ rázatással elősegítettük a képződő protoplasztok leválását. A sejtfal oldásához saját készítésű, éticsiga (Helix pomatia) gyomorból preparált lítikus emésztőenzimet használtunk. SMC pufferrel alaposan átmosva a micéliumkorongokat a protoplasztokat tölcsérbe helyezett gézen keresztül sterilen átszürtük, így megszabadultunk a micéliumtörmeléktől. A centrifugálással (2162 g, 10 perc, $4{ }^{\circ} \mathrm{C}$ ) összegyüjtött protoplasztokat $5 \mathrm{ml} \mathrm{SMC} \mathrm{pufferrel} \mathrm{mostuk,} \mathrm{majd}$ újabb centrifugálás után $250 \mu \mathrm{l}$ SMC pufferbe vettük fel.

\subsubsection{A protoplasztok transzformációja}

Az általunk alkalmazott módszer a van Heeswijck és Roncero (1984) által leírt PEGmediált transzformáció módosítása. A $250 \mu \mathrm{l}$ SMC pufferbe felvett protoplasztokhoz 5-10 $\mu \mathrm{g}$ plazmidot és $20 \mu \mathrm{l}$ PMC puffert adtunk, a protoplasztok és a transzformáló DNS összecsapásával elősegítve a transzformációt. Ezután a mintákat fél órán keresztül jégen inkubáltuk. További 2,5 $\mathrm{ml}$ PMC puffer hozzáadása után a mintákat 20 percig szobahőmérsékleten inkubáltuk. A mintákat $20 \mathrm{ml}$ SMC pufferrel hígítva centrifugáltuk. A protoplasztok regenerációjának elősegítéséhez a kiülepedett sejtekhez szorbitolt tartalmazó YPG tápoldatot adtunk, majd fél órán át $25^{\circ} \mathrm{C}$-on inkubáltuk őket. Centrifugálás után $\mathrm{SMC}$ pufferrel mostuk a sejteket, majd a kiülepített sejteket kis mennyiségü (100-200 $\mu 1)$ SMCben szuszpendáltuk és szorbitollal kiegészített YNB fedőagarral összekeverve szorbitolt tartalmazó YNB csészékre öntöttük. A dolgozatban szereplő vektorkonstrukciók pyrG gént hordoznak szelekciós markerként, ezért a táptalajokat leucinnal egészítettük ki. A csészéket 4-10 napig, a transzformáns telepek megjelenéséig szobahőmérsékleten inkubáltuk.

\subsubsection{Karotinkivonás}

A $M$. circinelloides MS12 törzsét és a transzformánsokat YNB csészéken 4 napig, állandó megvilágítás mellett tenyésztettük. A micéliumokat csipesz segítségével leszedtük a táptalaj felszínéről, majd a micéliumot dörzsmozsárban folyékony nitrogénnel elporítottuk. 
A karotinoidok fényérzékenysége miatt a teljes folyamatot sötétben végeztük. A karotinoidok extrahálásához 400-500 mg micéliumport használtunk, ehhez $500 \mu$ l acetont adtunk és erősen vortexeltük néhány percig. A mintákat centrifugáltuk (1.000 g, 1 perc), majd a felülúszót egy új csőbe vittük át. Az extrahálást addig ismételtük, amíg a sejttörmelék teljesen színtelen nem lett (6-10 extrakciós lépés). Az extraktumhoz ezután azonos mennyiségü petrolétert $\left(40-70^{\circ} \mathrm{C}\right)$, valamint a fázisok könnyebb szétválása érdekében $1 \mathrm{ml}$ desztillált vizet adtunk. A szerves fázist centrifugálás után új csőbe pipettáztuk át, majd a petrolétert nitrogéngáz áramoltatása mellett elpárologtattuk. A beszárított karotinoid mintákat $-20^{\circ} \mathrm{C}$-on tároltuk.

\subsubsection{A karotinoid kivonatok elemzése.}

A teljes karotinoid tartalom meghatározásához spektrofotometriás mérést alkalmaztunk. A beszárított, különböző pigmenteket tartalmazó mintákat petroléterben oldottuk, majd $450 \mathrm{~nm}$ hullámhosszon határoztuk meg az extinkció értékeket. Extinkciós koefficiensként 2500-al számoltunk (Rodriguez-Amaya 2001).

\subsubsection{Ergoszterinkivonás}

Az ergoszterin kivonáshoz Alcazar-Fuoli és munkatársai által (2008) leírt módszer módosított változatát használtuk. A micélium begyüjtését követően, a mintákat $85{ }^{\circ} \mathrm{C}$-on szárítottuk egy éjszakán keresztül. A szárítást követően 0,05-0,1 g micéliumot $15 \mathrm{ml}$

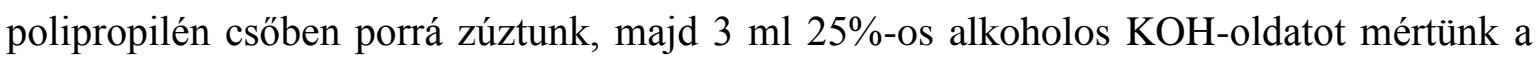
mintákra. 1 órás $85^{\circ} \mathrm{C}-$ os inkubálást követően a mintákhoz $1 \mathrm{ml}$ vizet és $3 \mathrm{ml}$ hexánt adtunk, majd 3 perc eröteljes vortexelés követően a mintákat 1000 g, 10 percig centrifugáltuk. A centrifugálás után a felső fázist új csőbe vittük át és állandó nitrogéngáz áramoltatása mellett beszárítottuk.

\subsubsection{Ergoszterinkivonatok elemzése}

$\mathrm{Az}$ ergoszterinminták analíziséhez nagyhatékonyságú folyadékkromatográfiát (HPLC) használtunk, melyhez egy moduláris Shimadzu rendszert alkalmaztunk egy kétcsatornás UV/VIS detektorral felszerelve. A szárított ergoszterin mintákat $1 \mathrm{ml}$ metanolba oldottuk, melyből $50 \mu$ l-t injektáltunk egy Prodigy C18 (4,6x250 mm, ODS 5 $\mu \mathrm{m})$ oszlopra (Phenomenex). Izokratikus elválasztást végeztünk $\mathrm{H}_{2} \mathrm{O} /$ metanol (2:98 v/v) mozgó fázis alkalmazásával és 1,2 $\mathrm{ml} /$ perces áramlási sebességgel. A detektálás 
hullámhossza 210 és $280 \mathrm{~nm}$ volt. Az ergoszterin azonosításához gyári standardot (Sigma) használtunk.

\subsubsection{A sztatinok minimális gátló koncentrációjának (MIC érték) meghatározása}

A kísérletek során fluvasztatint (Lescol, Novartis), rosuvasztatint (Crestor, Astra Zeneca) és atorvasztatint (Atoris, Krka) használtunk, melyekből a törzsoldatokat mindig frissen készítettük. A tenyésztés 96 lyukú mikrotiter lemezen (Costar 3599) történt YNB tápoldat (leucinnal és/vagy uracillal kiegészítve) felhasználásával.

A fluvasztatin törzsoldat készítéséhez $40 \mathrm{mg}$ hatóanyagot $1 \mathrm{ml}$ metanolban oldottunk fel, majd ezt tovább hígítottuk és az így kapott $2,5 \mathrm{mg} / \mathrm{ml}$ koncentrációjú fluvasztatin törzsoldatot használtuk. A rozuvasztatin esetében $20 \mathrm{mg}$ hatóanyagot $1 \mathrm{ml}$ metanolban, az atorvasztatin esetében pedig $10 \mathrm{mg}$ hatóanyagot $0,5 \mathrm{ml}$ metanolban oldottuk fel. A kapott oldatokat tovább hígítottuk $5 \mathrm{mg} / \mathrm{ml}$ koncentrációjú sztatin törzsoldatokká. A sztatin törzsoldatokból felező hígítási sort készítettünk 11 hígítási lépcsőben metanollal, majd a hígítást 50 szeresére hígítottuk YNB tápoldattal. A spóraszuszpenzió készítéséhez 4 napon keresztül nevelt tenyészetekröl steril desztillált vízzel mostuk le a spórákat, majd a tápoldattal $10^{5}$ spóra/ml töménységüre állítottuk be a spóraszuszpenziót, amiböl $100 \mu \mathrm{l}-\mathrm{t}$ mértünk a lyukakba. A mikrotiter lemezekre lyukanként $100 \mu$ l 50-szeresre hígított sztatin oldatot mértünk úgy hogy a fluvasztatin esetében a hatóanyag végkoncentrációja 128-0,25 $\mu \mathrm{g} / \mathrm{ml}$, az atorvasztatin és a rozuvasztatin esetében pedig 256-0,5 $\mu \mathrm{g} / \mathrm{ml}$ koncentráció tartományban legyen felező hígításban.

A kísérlet során több kontrollt is használtunk. A növekedési kontroll $100 \mu \mathrm{l}$ YNB tápoldat és $100 \mu$ l spóraszuszpenzió, az oldószerkontroll $100 \mu 1 \%$ metanolt tartalmazó YNB tápoldat és $100 \mu \mathrm{l}$ spóraszuszpenzió volt. Háttérkontrollként $200 \mu \mathrm{l}$ YNB tápoldatot alkalmaztunk. A mikrotiter lemezeket 3 napig $28{ }^{\circ} \mathrm{C}$-on, állandó hőmérsékleten tenyésztettük és 24,48 valamint 72 óra elteltével $620 \mathrm{~nm}$-en a tenyészet optikai denzitását lemértük egy Jupiter HD plate leolvasó segítségével (ASYS Hitech GmbH). Minden mérést 3 párhuzamosban végeztünk. Az átlagolás illetve a háttérabszorbancia levonása után a sztatinok gátlásának kiszámítását a növekedési kontrollhoz (100\%) viszonyítva adtuk meg.

\subsubsection{Mikroszkópos vizsgálatok}

A fény- és fluorescens mikroszkópos megfigyelésekhez AxioCam ERc 5s kamerával (Carl Zeiss) AxioLab (Carl Zeiss) felszerelt fluoreszcens mikroszkópot használtunk, a 
felvételek készítését és kiértékelését ZEN 2011 szoftver (Carl Zeiss) segítségével végeztük. A propidium jodid festés során szürőként filter szet 15-öt (excitáció BP 546/12 nm, emisszió LP 590 nm; Carl Zeiss) alkalmaztunk. Az annexin V - FITC festés során, valamint a GFP fúziós fehérje sejten belüli lokalizációjának vizsgálatához filter szet 9-t (excitáció BP 450490 nm, emisszió LP 515; Carl Zeiss) használtunk.

A konfokális mikroszkópos megfigyeléseket FluoView FV1000 (Olympus) típusú konfokális mikroszkóppal végeztük, melyhez FV10-ASW (Olympus) szoftvert alkalmaztunk. A GFP fúziós fehérjék sejten belüli lokalizációjának a megfigyeléséhez 488 nm excitációs és $510 \mathrm{~nm}$ emissziós szürőt használtunk, míg az ER-Tracker Red és MitoTracker Red festést követően $543 \mathrm{~nm}$ excitációs és $603 \mathrm{~nm}$ emissziós értékkel bíró szürőt alkalmaztunk.

\subsubsection{Membránfrakció izolálás}

A membrán izoláláshoz a törzseket YNB táptalajon tenyésztettük 2 napon keresztül, majd a táptalaj felszínéröl csipesz segítségével leszedtük a micéliumot. Ezt folyékony nitrogén segítségével porrá törtük, majd $4 \mathrm{~g}$ elporított micéliumhoz $8 \mathrm{ml}$ homogenizáló puffert mértünk. A mintát kémcsőkeverő segítségével homogenizáltuk, majd 10 percig jégen inkubáltuk. Az inkubálás után a mintát $500 \mathrm{~g}$ fordulatszámon, 15 percig centrifugáltuk. A centrifugálást követően a felső fázist ultracentrifuga csőbe vittük át és 100.000 g-vel, 1 órán keresztül centrifugáltuk. A felső fázis tartalmazta a szolubilis fehérjéket, míg a pellet a membrán frakciót.

\subsubsection{A membránfrakció fluoreszcenciájának vizsgálata}

Az ultracentrifugálást követően a membránfrakciót $1 \mathrm{ml}$ homogenizáló pufferbe oldottuk. A membránfrakció fluoreszcenciáját először fluoreszcens mikroszkóppal (Zeiss Axiolab) közvetlenül vizsgáltuk, majd fluoriméterrel is meghatároztuk. Utóbbi során, 100 $\mu 1$ mintát fekete 96 lyukú mikrotiter lemezre (Greiner Bio One) vittünk át, majd azt FLUOstar OPTIMA (BMG Labtech) készülék segítségével vizsgáltuk. Excitációs filternek 485 BP-t, emissziós filternek 500-10-t használtunk. Háttérkontrollként a homogenizáló puffert alkalmaztuk. 


\subsubsection{Statisztikai elemzések}

Az adatok kiértékelését, az átlagok és szórások, valamint a különbségek szignifikanciájának kiszámítását Microsoft Excel program segítségével végeztük, utóbbi esetben párosított vagy párosítatlan t-próbát alkalmaztunk. 


\section{EREDMÉNYEK ÉS ÉRTÉKELÉSÜK}

\subsection{A Mucor circinelloides 3-hidroxi-3-metilglutaril koenzim A reduktáz génjeinek izolálása és a gének elemzése}

A M. circinelloides teljes genomjának meghatározása 2010-ben fejeződött be (http://genome.jgi-psf.org/Mucci2/Mucci2.home.html), ami nagymértékben elösegítette az egyes bioszintézis utakban szerepet játszó gének keresését és azonosítását. Munkánk elején a $P$. blakesleeanus (X58371, Ruiz-Albert és mtsi. 2002) és a laborunkban korábban azonosított $R$. miehei (AJ568024, Lukács és mtsi. 2009) hmgR génjeivel kerestünk homológ szekvenciákat a Mucor adatbázisban. Három olyan feltételezett gént találtunk ( $h m g R l$ scaffold_02: 2759562-2763160; hmgR2 - scaffold_03: 4299175-4302130 és hmgR3 scaffold_04: 4237143-424075), amelyek nagyfokú hasonlóságot mutattak a Phycomyces és Rhizomucor hmgR génekkel.

A kapott szekvenciákra alapozva specifikus indítószekvenciákat terveztünk (1. táblázat), melyek segítségével mind három gént ( $h m g R 1, h m g R 2$ és $h m g R 3)$ az őket határoló régiókkal együtt és a megfelelő cDNS-eket sikerült felszaporítani (1. melléklet). A meghatározott nukleotid szekvenciákat az NCBI GenBank adatbázisba depozitáltuk. A hmgRl (GenBank azonosító: KJ508882.1) kódoló szakasza 3740 bp hosszúságú, melyben a cDNS szekvencia meghatározásával öt intront azonosítottunk (54, 82, 74, 58 és 55 bp hosszúságúak). A hmgR2 gén (GenBank azonosító: KJ508884.1) 3595 bp hosszú és szintén öt intront tartalmaz (59, 53, 79, 124 és 58 bp hosszúságúak), míg a hmgR3 (GenBank azonosító: KJ508883.1) esetében egy 3491 bp hosszúságú kódoló régiót azonosítottunk két darab intronnal (65 és 81 bp hosszúságúak). Az intronok mindegyike tartalmazza az 5' végén a GT, 3' végén pedig az AG motívumokat. A $h m g R l$ és $h m g R 2$ esetében a stop kodont a TAA, míg a hmgR3 esetében a TAG triplet kódolja.

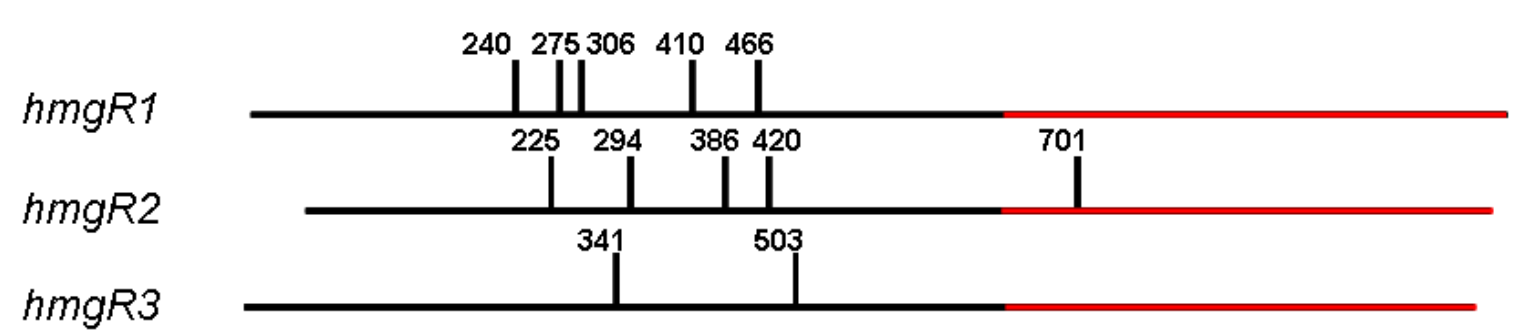

6. ábra. A M. circinelloides hmgR génjeiben található intronok elhelyezkedése.

A kódolt fehérjeszekvenciákat jelképező vonalak hossza arányos a fehérjeszekvenciák hosszával, egymáshoz viszonyított helyzetük, a pirossal jelölt, C-terminális régióik konzervált fehérjeszakaszainak egymás alá rendezéséből következik. A számok a fehérjeszekvenciáknak azt az aminosavát jelölik, amelynek kodonja után a génben az intron elhelyezkedik. 
A 6. ábrán látható, hogy $h m g R 2$ esetében azonosítottunk egy olyan intron szakaszt, mely a fehérje katalitikus aktivitásáért felelős régiójában helyezkedik el. A járomspórás gombák közül a $R$. miehei hmgR gén 5 (Lukács és mtsi. 2009), míg a P. blakesleeanus hmgR gén 4 intron tartalmaz (Ruiz-Albert és mtsi. 2002). Lukács és munkatársai (2009) a R. miehei és a $P$. blakesleeanus $h m g R$ gének intron pozícióinak összehasonlításakor, arra a megállapításra jutottak, hogy a Rhizomucor $h m g R$ utolsó 4 intronja azonos pozícióban helyezkedik el a Phycomyces $h m g R$ intronjaival. Ez arra utal, hogy a $h m g R$ génekben az intronok pozíciója valamilyen szinten konzervált. Azonban a $M$. circinelloides $h m g R$ génjeiben található intron pozíciók, a Rhizomucor és Phycomyces intron pozícióival történő összevetésekor nem állapíthattunk meg ilyen egyértelmű konzerváltságot. Ahogy a három gén esetében is látható, az intronok mennyisége és elhelyezkedése igen variábilis. A $S$. cerevisiae, Sch. pombe, C. glabrata és C. albicans $h m g R$ génjei ezzel szemben nem tartalmaznak intronokat (Andrade-Pavón és mtsi. 2013).

\subsection{A M. circinelloides HMG-KoA reduktázainak jellemzése}

A PCR reakció során felszaporított feltételezett $h m g R$ gének cDNS-ének szekvenáltatása után megállapítottuk a fehérjék feltételezett aminosav sorrendjét. A feltételezett fehérjék főbb tulajdonságait a 3. táblázat tartalmazza.

3. táblázat. A M. circinelloides HMG-KoA reduktázok főbb tulajdonságai.

\begin{tabular}{cccc}
\hline & HmgR1 & HmgR2 & HmgR3 \\
\hline $\begin{array}{c}\text { Hossz (aminosav) } \\
\text { Számolt molekula } \\
\text { tömeg }\end{array}$ & 1138 & 1073 & 1114 \\
$\begin{array}{c}\text { Számolt pI } \\
\text { Transzmembrán } \\
\text { hélixek száma }\end{array}$ & $124,52 \mathrm{kDa}$ & $118,32 \mathrm{kDa}$ & $120,71 \mathrm{kDa}$ \\
$\begin{array}{c}\text { Szterol-érzékelő } \\
\text { domén }\end{array}$ & 9,11 & 8,49 & 8,43 \\
HMG-kötő & 6 & 9 & 5 \\
motívum & CENVIGYMPIP & CENVIGYMPIP & CENVIGYMPIP \\
& (749-759 as) & (687-697 as) & (756-766 as) \\
PMATTEGCLVA & PMATTEGCLVA & PMATTEGCLIA \\
NAD(P)H kötő & (776-786 as) & (714-724 as) & (783-793 as) \\
motívum & (872-879 as) & TGDAMGMN & TGDAMGMN \\
& (810-817 as) & (879-886 as) \\
& $(1022-1029$ as) & VGTIGGGT & VGTIGGGT \\
(960-967 as) & (1029-1036 as) \\
\hline
\end{tabular}


A három $h m g R$ gén által kódolt, feltételezett HmgR1, HmgR2 és HmgR3 fehérje méretükben, izoelektromos pontjukban és a transzmembrán hélixek számában eltéréseket mutattak.

Az enzimek állatok és gombák esetében 7-8 transzmembrán doménnel rendelkeznek (Basson és mtsi. 1988; Croxen és mtsi. 1994; Olender és Simoni 1992; Roitelman és mtsi. 1992), míg növények esetében ez a szám általában 2 (Genschik és mtsi. 1992; Learned és Fink 1989; Nelson és mtsi. 1994). A M. circinelloides HmgR1 esetében 6, a HmgR2 esetében 9, míg a HmgR3 esetében 5 transzmembrán hélixet azonosítottunk. Szíriai aranyhörcsög HMG-KoA reduktáz fehérjéjének esetében azonosítottak egy szignált az első transzmembrán régióban, amely az enzimet az ER-be irányítja (Oleander és Simoni 1992), azonban mi a három vizsgált fehérje aminosav szekvenciájában nem találtunk ehhez hasonló szignálszekvenciát. Az $\mathrm{N}$-terminális régió feltételezett transzmembrán hélixeken kívül tartalmaz egy szterol érzékelésért felelős domént (SSD), mely érzékeli a szterolok mennyiségét a sejten belül (Loftus és mtsi. 1997, Brown és Goldstein 1999, Davies és Ioannou 2006) és szerepet játszik az enzim poszttranszlációs szabályozásában. S. cerevisiae Hmg2p esetében Chandra és munkatársai (2011) kimutatták, hogy ez az SSD domén közvetlenül szabályozza az enzim ER-asszociált lebomlását (ERAD), valamint előkészíti az enzimet a degradációs útvonalba való belépéshez.
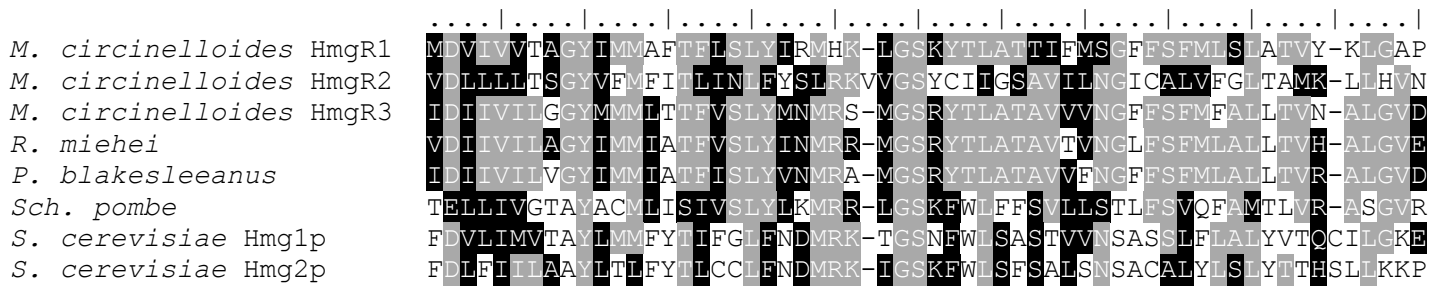

M. Circinelloides HmgR1 M. circinelloides HmgR2

M. circinelloides HmgR3

R. miehei

P. blakesleeanus

Sch. pombe

S. cerevisiae Hmglp

S. cerevisiae $\operatorname{Hmg} 2 \mathrm{p}$

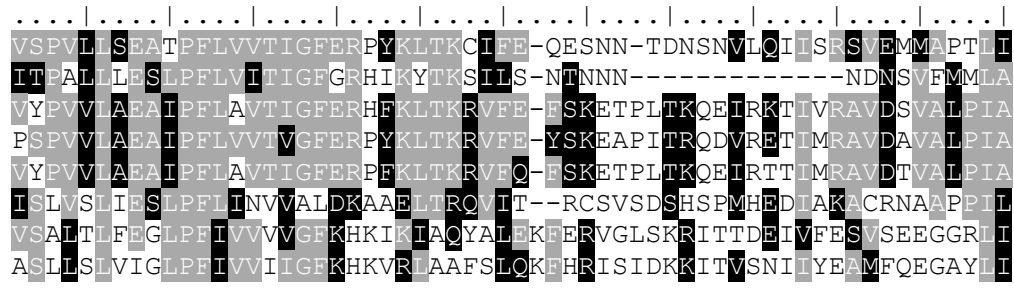

M. Circinelloides HmgR1

M. circinelloides HmgR2

M. Circinelloides HmgR3

R. miehei

P. blakesleeanus

Sch. pombe

S. Cerevisiae Hmglp

S. cerevisiae Hmg2p

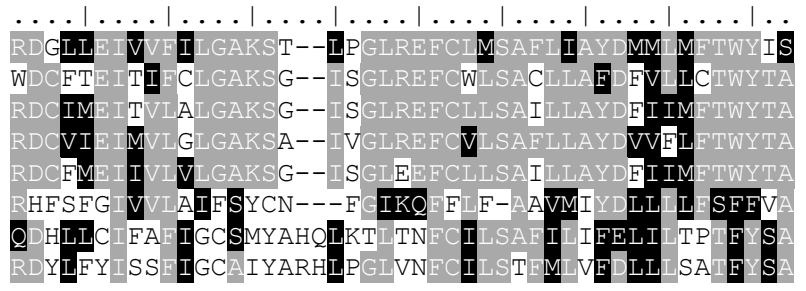

7. ábra. A HMG-KoA reduktázban található szterol érzékelő domének aminosav sorrendjeinek összehasonlítása néhány gombafaj esetében.

A szürke háttér az azonos, míg a fekete háttér a hasonló karakterü aminosavakat jelöli. 
Az 7. ábrán látható, hogy a Mucor HmgR2 szterol érzékelő doménjében egy 13 aminosavnyi hiány található. Emiatt az aminosav hiány miatt, feltehetőleg eltérő lehet az enzim szterol érzékelő képessége és a poszt-transzlációs szabályozása.

Az HMG-KoA reduktáz C-terminális része igen erősen konzervált. Mind három fehérjében megtalálható a HMG-kötésért felelős CENVIGYMPIP és PMATTEGCLVA motívum (Istvan és mtsi. 2000) valamint a NAD(P)H kötődésért felelős TGDAMGMN és VGTVGGGT motívum (3. táblázat). A 8. ábrán néhány gombafaj HMG-KoA reduktáz katalitikus aktivitásért felelős régiójának összehasonlítása látható.

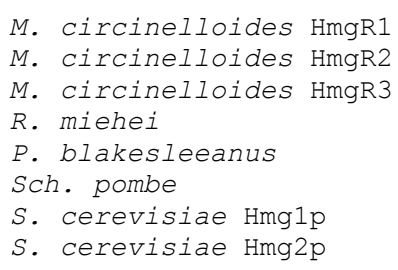

M. Circinelloides HmgR1 M. circinelloides HmgR2

M. circinelloides HmgR3

R. miehei

P. blakesleeanus

Sch. pombe

S. cerevisiae Hmglp

S. cerevisiae Hmg2p

M. Circinelloides HmgR1

M. circinelloides HmgR2

M. Circinelloides HmgR3

R. miehei

P. blakesleeanus

Sch. pombe

S. cerevisiae Hmglp

S. cerevisiae Hmg2p

M. Circinelloides HmgR1

M. Circinelloides HmgR2

M. circinelloides HmgR3

R. miehei

P. blakesleeanus

Sch. pombe

S. cerevisiae Hmglp

S. cerevisiae $\operatorname{Hmg} 2 \mathrm{p}$

M. circinelloides HmgR1

M. circinelloides HmgR2

M. circinelloides HmgR3

R. miehei

P. blakesleeanus

Sch. pombe

S. cerevisiae Hmglp

S. cerevisiae $\operatorname{Hmg} 2 \mathrm{p}$
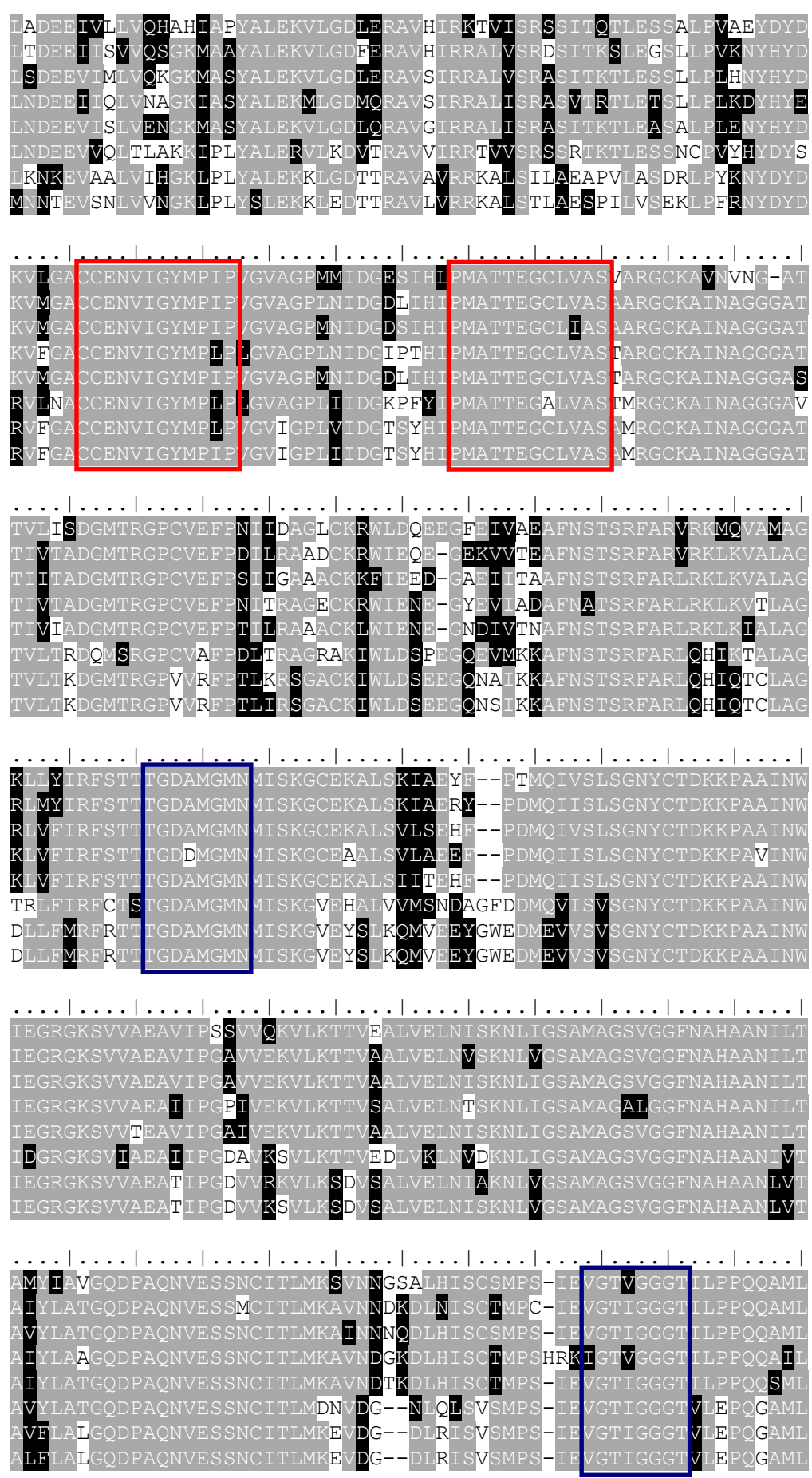

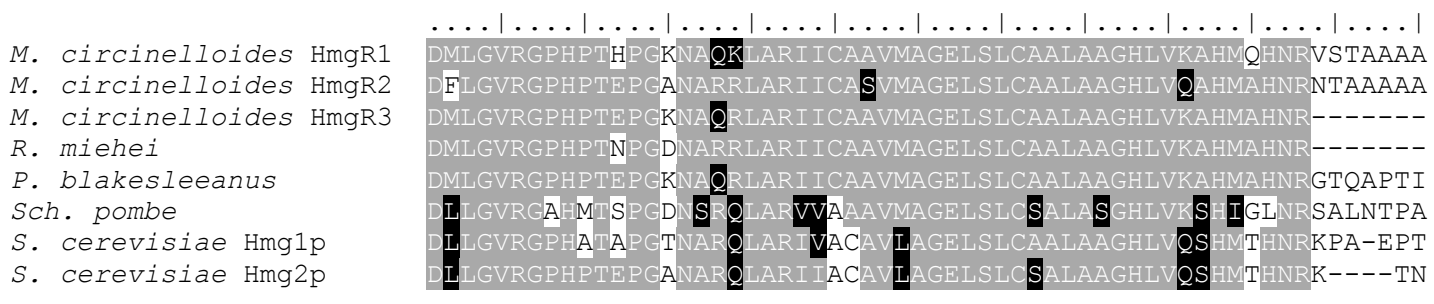

M. circinelloides HmgR1

M. circinelloides HmgR2

M. circinelloides HmgR3

R. miehei

P. blakesleeanus

Sch. pombe

S. cerevisiae Hmglp

S. cerevisiae Hmg2p

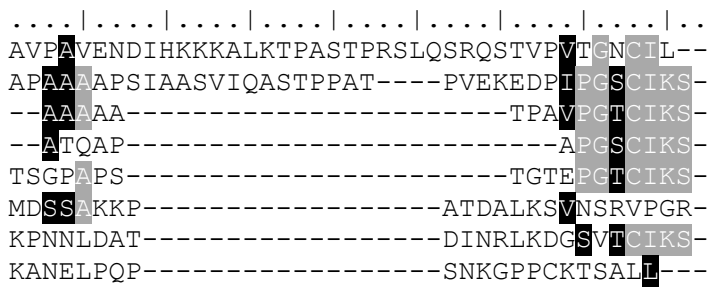

8. ábra. A HMG-KoA reduktáz katalitikus régiójának összehasonlítása néhány gombafaj esetében. A szürke háttér az azonos, a fekete háttér a hasonló karakterü aminosavakat jelöli. Piros kerettel vannak jelölve a HMG-kötö, kékkel pedig a NAD(P)H-kötő motívumok.

P. blakesleeanus-ban Ruiz-Albert és munkatársai (2002) kimutattak egy rövid, Cterminális ún. PEST szekvenciát, mely általában szignálként szolgál az enzim gyors lebontásához. Ilyen szignálszekvenciát a Mucor három reduktázában nem találtunk. Összehasonlítva a Mucor három reduktáz fehérjéjének teljes aminosav sorrendjét valamint a katalitikus régiót, a HmgR2 és HmgR3 bizonyult a leghasonlóbbnak (identikus aminosav pozíciók aránya a teljes fehérje és a katalitikus régió esetében $67 \%$ és $79 \%$ volt). Ezzel szemben a HmgR1 teljes aminosav sorrendje a HmgR2-ével 55\%-ban, a HmgR3-éval 51\%ban volt azonos, míg a katalitikus régiók 68 és 70\%-os egyezést mutattak.

\subsection{Az egyes $h m g R$ gének kifejeződésének vizsgálata különböző tenyésztési}

\section{körülmények között.}

A gének kifejeződésének vizsgálatához valós-idejü kvantitatív PCR-t (qPCR) alkalmaztunk. A primerek megtervezése után optimalizáltuk az amplifikálás körülményeit. Referencia génként az aktint (scaffold_07: 2052804-2054242) választottuk. Az optimalizáláshoz először DNS templátot használtunk és figyeltük a reakció során keletkező termékek megjelenését. A qPCR reakciók során az egyes PCR termékek egyazon ciklusidő (CT) értéknél jelentek meg, valamint a melting curve analízis alapján, reakciónként egy-egy specifikus terméket detektáltunk. Ezután RNS-t izoláltunk, melyet reverz transzkriptázzal cDNS-sé írtunk át. Az így nyert cDNS-sel ismét PCR reakciót mértünk össze a primerek és az amplifikálás körülményeinek ellenőrzése céljából. A $h m g R 1$ esetében 151, a hmgR2 esetében 107, a hmgR3 esetében 128, míg az aktin esetében 117 nukleotidnyi terméket szaporítottunk fel (9. ábra). A kísérletekhez a M. circinelloides MS12 törzsét használtuk. 


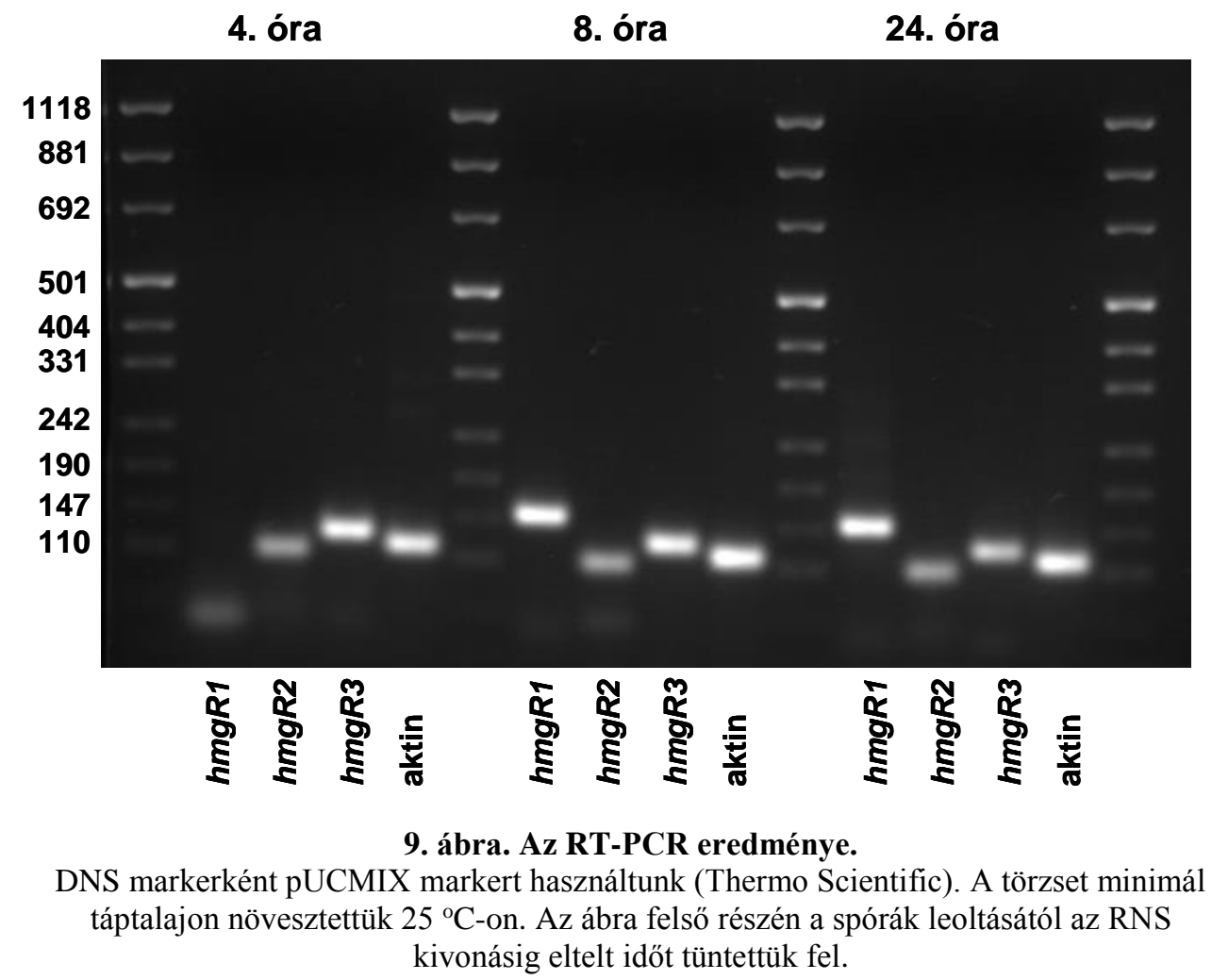

\subsubsection{A $h m g R$ gének relatív transzkripciós szintjei a tenyésztési időszak alatt.}

Megvizsgáltuk a gének kifejeződését a tenyésztési időszak alatt. A tenyésztést minimál táptalajon $25{ }^{\circ} \mathrm{C}$-on végeztük. A vizsgálatot a spórák leoltásától számított 4. órától a 96. óráig végeztük. A $M$. circinelloides esetében a spórák leoltását követő 4. órában jelennek meg a csíratömlök, a 8. órában már intenzív micéliumképzés figyelhető meg (10. ábra).

(a)

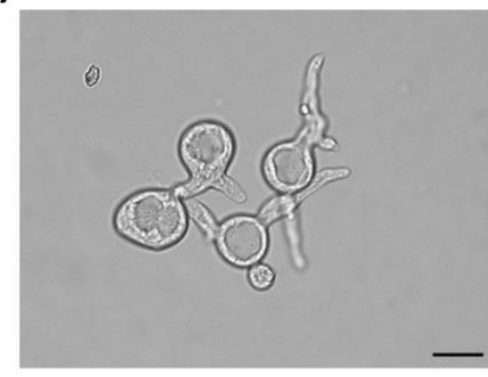

(b)

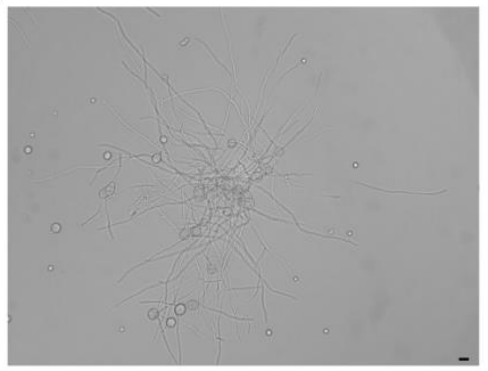

10. ábra. A M. circinelloides csírázó spóráinak és fiatal hifáinak morfológiája a leoltástól számított 4. (a) és 8 (b) órában.

A méret skála $10 \mu \mathrm{m}$-nek felel meg.

A tenyésztési idő alatt a $h m g R 2$ és $h m g R 3$ végig hasonló relatív transzkripciós szinteket mutatott. Mindkét gén magas értéket ért el a leoltástól számított 4. órában, ezzel jelezve, hogy a gének átíródása már a csírázás időpontjában aktív. A hmgRl esetében alig 
detektáltunk transzkripciót a leoltástól számított 4. órában. A 9. és 11. ábrán jól látszik, hogy a $h m g R l$ még nem aktív a spórák csírázásának idején. A $h m g R l$ és a $h m g R 3$ a legmagasabb transzkripciós szintet a leoltástól számított 48. órában érték el, míg ez az érték a $h m g R 2$ esetében a 8. órában volt mérhetö, amikor beindult az intenzív micéliumképzés.
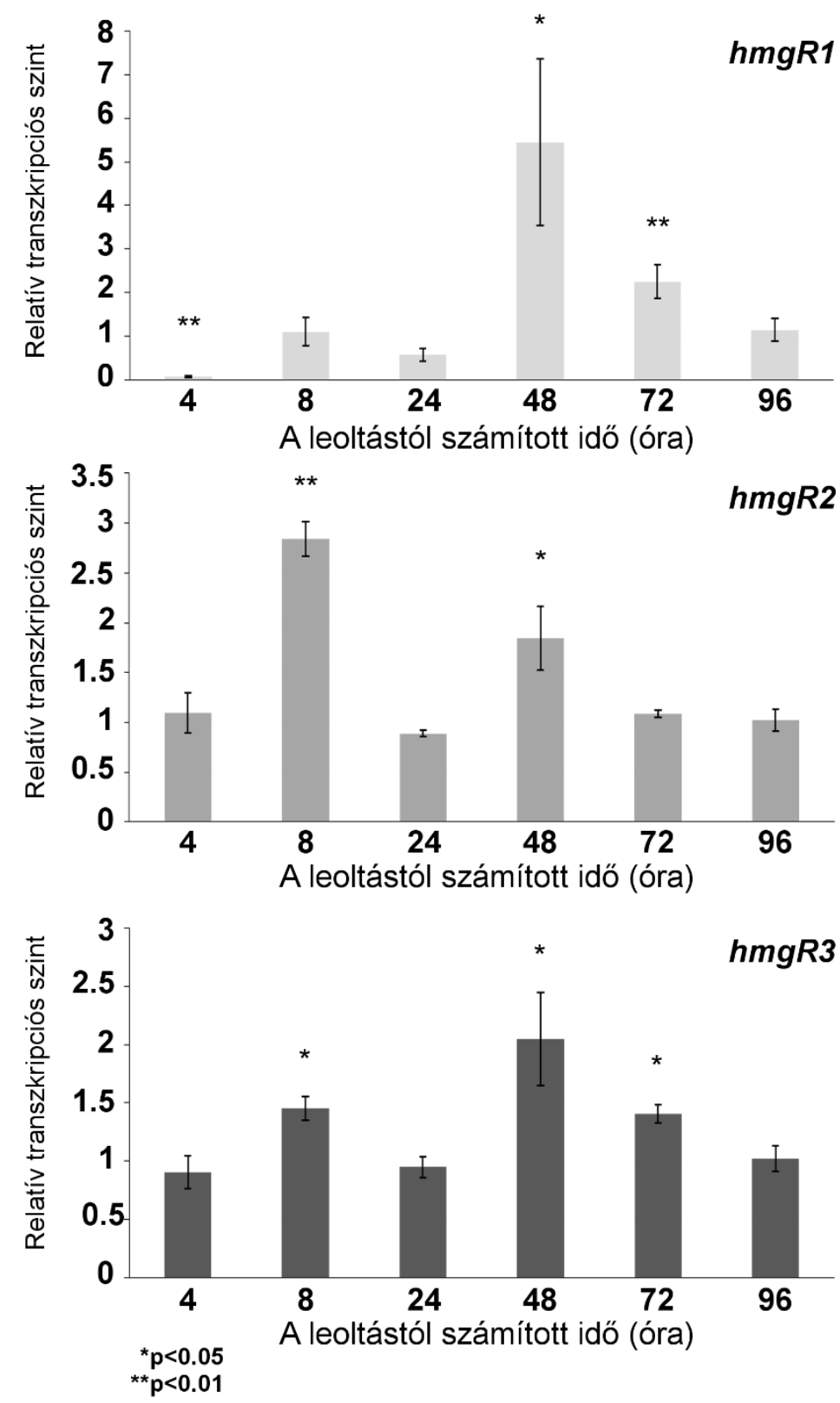

11. ábra A $h m g R$ gének relatív transzkripciós szintjei a tenyésztési idő alatt.

Mindegyik gén esetében a 96. órában mért értékhez viszonyítottunk. A diagramon három egymástól független mérés eredményeinek átlagértékeit tüntettük fel szórással együtt, * és ** jelzi a 96. órában mért értéktől való szignifikáns eltérést. A szignifikancia szint megállapításához párosított t-próbát végeztünk.

A $3 h m g R$ gén relatív transzkripciós szintjét egymáshoz hasonlítva, megállapíthatjuk, hogy a tenyésztési időszak alatt végig a $h m g R 2$ mutatta a legnagyobb transzkripciós szintet, míg a legalacsonyabbat a $h m g R l$ (12. ábra). 


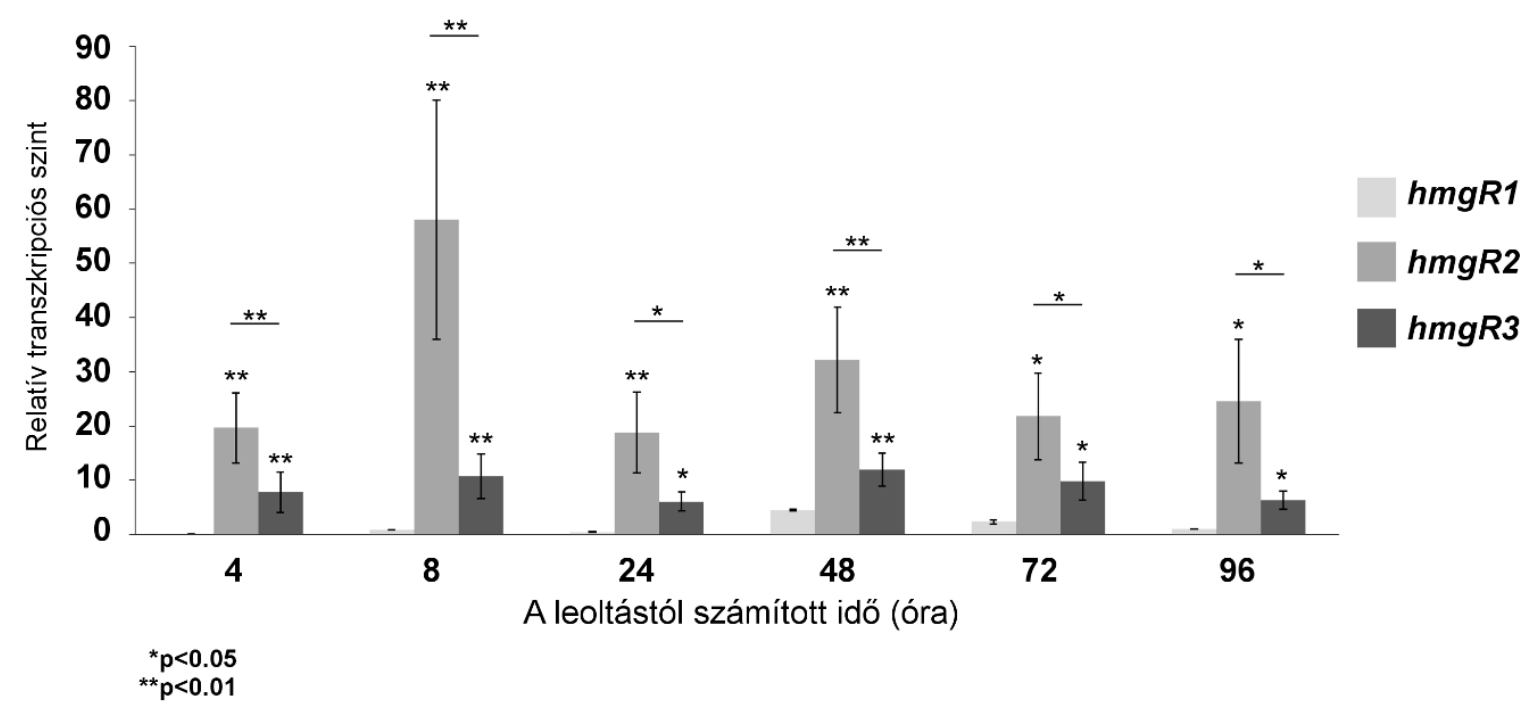

12. ábra. A M. circinelloides 3 hmgR génjének relatív transzkripciós szintje a tenyésztési idő alatt. Az eredményeket három egymástól független mérés után kaptuk, a szórás jelzi a mérések közötti eltéréseket. A $h m g R 1$ gén 96. órában mért relatív transzkripciós szintjéhez viszonyítottunk. A vízszintes vonalak jelzik a $h m g R 2$ és $h m g R 3$ gén relatív transzkripciójának szignifikáns különbségeit, míg az oszlopok feletti csillagok a

$h m g R 1$ génhez viszonyított szignifikáns eltérésekre utalnak. A szignifikancia szint megállapításához párosítatlan t-próbát végeztünk.

A fenti ábrákon látható, hogy a $h m g R 2$ és a $h m g R 3$ relatív transzkripciós mintázata hasonló egymáshoz és eltér a $h m g R l$ esetében mérttől. Az eredmények azt mutatják, hogy a $h m g R l$ csak a micéliumban fejeződik ki, és a relatív transzkripció szintjének a maximumát a leoltástól számított második napon éri el. Ezzel szemben a $h m g R 2$ és $h m g R 3$ már a csírázó spórákban is aktívak és ez az aktivitás megmarad a fiatal hifákban is. A szakirodalomból ismert, hogy a HMG-KoA reduktáz hatással van a gomba morfogenezisére és polarizált növekedésére (Lukács és mtsi. 2009; Seiler és Plamann 2003; Nickerson és mtsi. 2006), azonban igen kevés információval rendelkezünk a spórák csírázásában és a hifaképzés során betöltött szerepéröl. Basson és munkatársai (1986) kimutatták, hogyha deletálják a $S$. cerevisiae Hmg1p vagy Hmg2p génjét, akkor nem történik meg a spórák csírázása és a növekedés. Az eredményeink azt mutatják, hogy a $h m g R 2$ és $h m g R 3$, a Mucor esetében, már a spórák csírázásának és az intenzív micélium képzésének idejében fontos szerepet töltenek be. A leoltástól számított 48. órában kezdődik meg a spóratartók és a spórák képzése. Mivel a $h m g R l$ átíródása ebben az időben a legmagasabb, lehetséges, hogy valamilyen szerepe lehet a spóraképzésben, azonban a 11. ábrán látható, hogy mindhárom reduktáz gén esetében magas relatív transzkripciós szintet mértünk ebben az időpontban. 


\subsubsection{A $h m g R$ gének relatív transzkripciós szintjei különböző hőmérsékleten.}

A környezethez való alkalmazkodásban jelentős szerepe van a sejtmembrán szerkezetének és fluiditásának. A gombák sejtmembránjának fő szterin komponense és így a membránszerkezet egyik fontos eleme, az ergoszterin, melynek képződését a HMG-KoA reduktáz aktivitása meghatározza. Utóbbi ily módon, közvetve maga is szerepet játszik a környezethez való alkalmazkodásban.
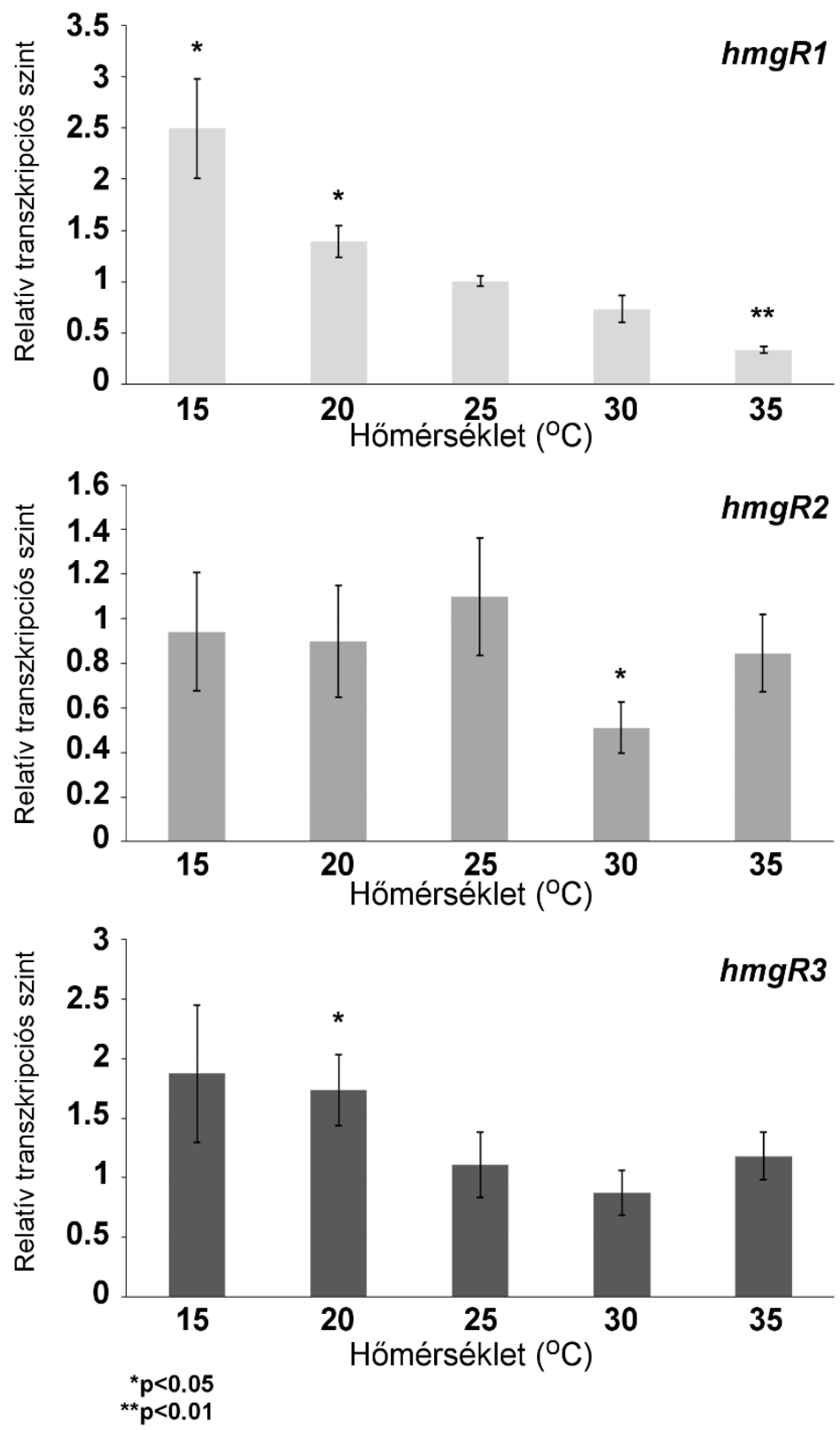

13. ábra. A hmgR gének relatív transzkripciós szintjei különböző hőmérsékleteken Mindegyik gén esetében a $25^{\circ} \mathrm{C}$-on mért értékhez viszonyítottunk. A diagramon három egymástól független mérés eredményeinek átlagértékeit tüntettük fel szórással együtt, * jelzi a $25^{\circ} \mathrm{C}$-on mért értéktől való szignifikáns eltérést. A szignifikancia szint megállapításához párosított t-próbát végeztünk. 
Gyakorlati szempontból is érdemes megvizsgálni a hőmérséklet hatását a másodlagos metabolitok termelődésére és a bioszintézükben szerepet játszó gének kifejeződésére, ugyanis a különböző élölények karotinoid termelésére eltérő módon hat a megváltozott hőmérséklet (Bhosale 2004).

Négy napig minimál táptalajon tenyésztve a törzset, megvizsgáltuk a különböző hőmérsékletek hatását az egyes reduktáz gének relatív transzkripciós szintjére nézve (13. ábra). A hmgRl esetében az tapasztaltuk, hogy a növekvő hömérséklettel párhuzamosan a gén relatív transzkripciós szintje szignifikánsan csökkent. Nem tapasztaltunk viszont hőmérsékletfüggést a $h m g R 2$ és $h m g R 3$ esetében. A $h m g R 2$ esetében csak $30{ }^{\circ} \mathrm{C}$-on tapasztaltunk szignifikáns transzkripciós szint csökkenést a $25{ }^{\circ} \mathrm{C}$-hoz képest, míg $h m g R 3$ esetében transzkripciós szint növekedést tapasztaltunk $20^{\circ} \mathrm{C}$-on. A tenyésztési hőmérséklet nagyban befolyásolja az egyes másodlagos metabolitok termelődését, melyek nem csak a sejtmembrán kialakításában játszanak szerepet. A járomspórás gombák karotinoid termelését nagymértékben befolyásolja a hőmérséklet (Mosqueda-Cano és GutierrezCorona 1995; Nagy és mtsi. 2012; Papp és mtsi. 2013). M. rouxii esetében az optimális 28 ${ }^{\circ} \mathrm{C}$-ról $40{ }^{\circ} \mathrm{C}$-ra emelve a hőmérsékletet háromszorosára nőtt a termelődött karotinoid mennyisége (Mosqueda-Cano és Gutierrez-Corona 1995), ezzel szemben Dunaliella esetében $34 \quad{ }^{\circ} \mathrm{C}$-ról $17 \quad{ }^{\circ} \mathrm{C}$-ra csökkentve a hömérsékletet 7,5-szeresére nőtt karoinoidmennyiség (Orset és Young 1999). Az MS12 törzs karotinoid termelését is nagyban befolyásolja a hőmérséklet. A transzkripciós vizsgálatokhoz felhasznált tenyészet karotinoid tartalmát megvizsgálva (14. ábra) arra a megállapításra jutottunk, hogy $30{ }^{\circ} \mathrm{C}$-on tenyésztve a törzset az termelt karotinoid mennyisége lecsökken a $25{ }^{\circ} \mathrm{C}$-on mért értékhez képest, míg $35^{\circ} \mathrm{C}$-on tenyésztve ismét megnő (Nagy és mtsi. 2012). Hasonló növekedést és csökkenést tapasztaltunk a $h m g R 2$ gén transzkripciós szintjének mérésekor is.

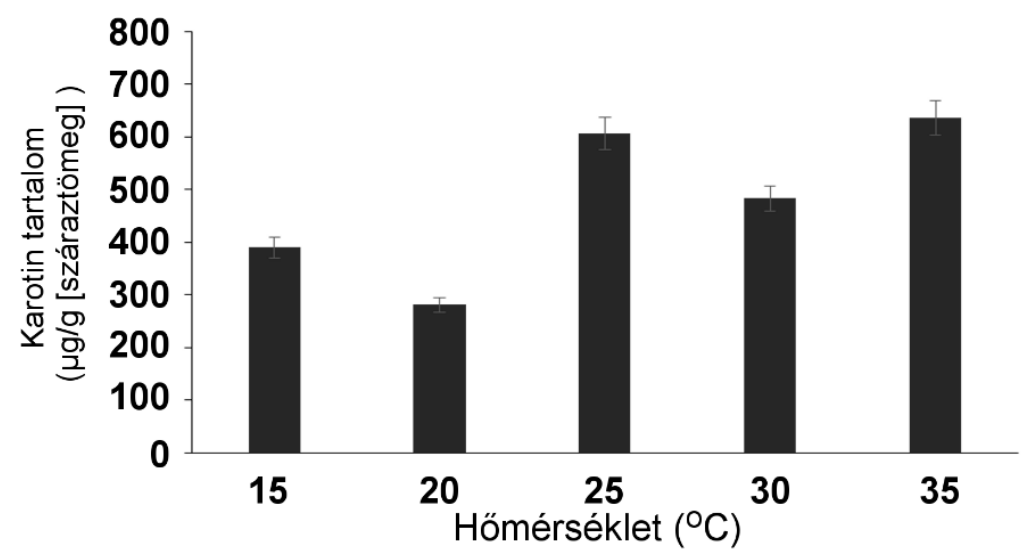

14. ábra. Az MS12 karotinoid tartalma különböző hőmérsékleteken.

Az eredményeket három egymástól független mérés után kaptuk, a szórás jelzi a mérések közötti eltéréseket. 


\subsubsection{Sóstressz hatása a Mucor $h m g R$ génjeinek relatív transzkripciójára}

A HMG-KoA reduktáz aktivitása és az enzim sejten belüli szintje esszenciális a halotoleráns fenotípus kialakításához, valamint az ozmotikusan megváltozott környezethez való adaptálódáshoz (Vaupotič és mtsi. 2008; Bidle és mtsi. 2007). H. werneckii esetében az enzim lovasztatinnal történő gátlása sószenzitív fenotípus megjelenését eredményezte (Vaupotič és mtsi. 2008).
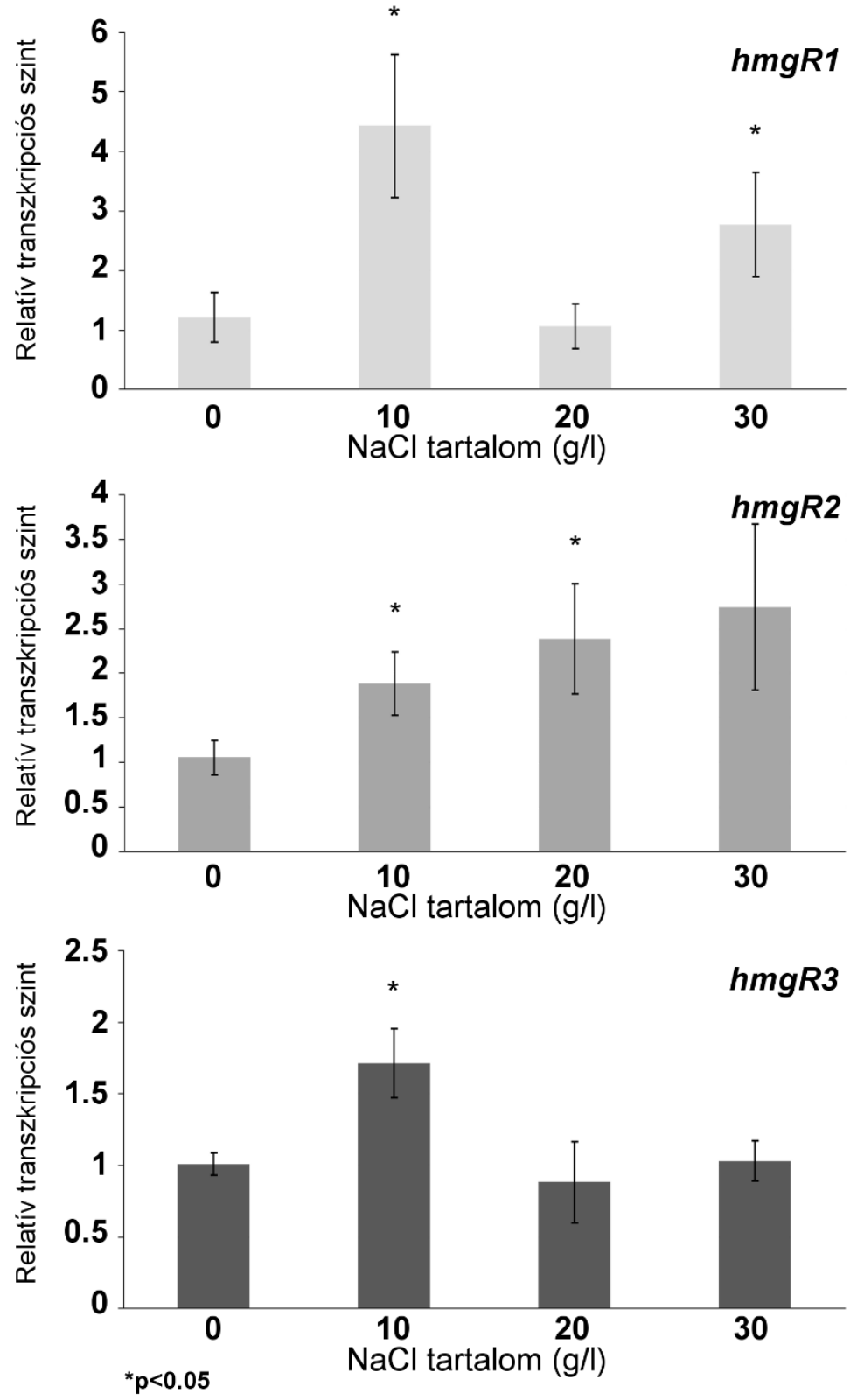

15. ábra. A hmgR gének relatív transzkripciós szintjei sóstressz hatására.

Mindegyik gén esetében a $0 \mathrm{~g} / 1$ sótartalom mellett mért értékhez viszonyítottunk. A diagramon három egymástól független mérés eredményeinek átlagértékeit tüntettük fel szórással együtt, * jelzi a 0 g/l sótartalom mellett mért értéktől való szignifikáns eltérést. A szignifikancia szint megállapításához párosított t-próbát végeztünk. 
Mindezek mellett fontosnak találtuk megvizsgálni a $M$. circinelloides esetében is a sóstressz hatását az egyes $h m g R$ gének relatív transzkripciójára (15. ábra). A tenyésztést 25 ${ }^{\circ} \mathrm{C}$-on különböző koncentrációjú (10, 20 és 30 g/l) NaCl-dal kiegészített minimál táptalajokon végeztük 4 napig. Só jelenlétében mindhárom gén relatív transzkripciós szintjében tapasztaltunk változást. $H m g R l$ és $h m g R 3$ esetében a gének relatív transzkripciós értékük maximumát $10 \mathrm{~g} / 1$ só jelenlétében érték el, míg a $h m g R 2$ esetében a növekvő sókoncentrációval párhuzamosan a relatív transzkripciós szint is nőtt. $30 \mathrm{~g} / 1$ só koncentráció mellett a gomba növekedése már nagymértékben gátolt volt, ezért nem vizsgáltunk magasabb sókoncentráció mellett a gének kifejeződését.

A só szenzitív S. cerevisiae és a mérsékelten halotoleráns Aureobasidium pullulans fekete élesztő esetében a megnövekedett só koncentráció jelenlétében nőtt a HMG-KoA reduktáz fehérje szintje és annak aktivitása (Vaupotič és mtsi. 2008). M. circinelloides esetében is azt tapasztaltuk, hogy a só jelenlétére mindhárom $h m g R$ gén reagált, azonban csak a $h m g R 2$ esetében tapasztaltunk növekvő génkifejeződést a növekvő sókoncentrációval párhuzamosan. A megváltozott környezethez való alkalmazkodáshoz elengedhetetlen a membrán fluiditásának, többek között a szterin összetétel változásán keresztül történő, megváltoztatása. H. werneckii halofil élesztőgomba két HMG-KoA reduktáza (HwHMG1 és HwHMG2) a sejten belül eltérő helyen lokalizálódik. A mitokondriális HwHMG2 kifejeződése a körülményektől függetlenül azonos kifejeződést mutat, míg az ER-ben lokalizálódó HwHMG1 enzim aktivitása az optimális értéktől eltérő, annál alacsonyabb vagy magasabb, sókoncentráció mellett megemelkedik (Vaupotič és mtsi. 2008).

\subsubsection{A $h m g R$ gének relatív transzkripciós szintjei különböző szénforrásokon}

Arról nem volt előzetes információnk, hogy az egyes szénforrások, hogyan befolyásolják a $h m g R$ gének kifejeződését. A vizsgálat során olyan szénforrásokat alkalmaztunk, melyekről korábban bebizonyosodott, hogy kedvező hatással vannak a Mucor karotinoid bioszintézisére (Nagy és mtsi. 2012; Papp és mtsi, 2013). A vizsgálathoz a $M$. circinelloides-t YNB táptalajon növesztettük 4 napig. Egyedüli szénforrásként glükózt, maltózt, trehalózt, nátrium-acetátot és dihidroxi-acetont (DHA) használtunk.

A gének kifejeződése mellett megvizsgáltuk a törzs adott szénforráson mutatott morfológiáját is (16. ábra). Nátrium-acetáton és DHA-n volt a legszembetűnőbb a morfológiai változás a glükózhoz képest. Nátrium-acetáton vékony, hosszú hifák képződtek (16. ábra piros nyilak), míg DHA-n a tenyészet pellet szerü volt és a hifák rövidek és megvastagodtak (16. ábra fekete nyilak). Maltózzal és trehalózzal kiegészített tápoldatban 
nem tapasztaltunk jelentős morfológiai változást a kontrollhoz képest (16. ábra), azonban az artrospórák száma ezeken a szénforrásokon megemelkedett.
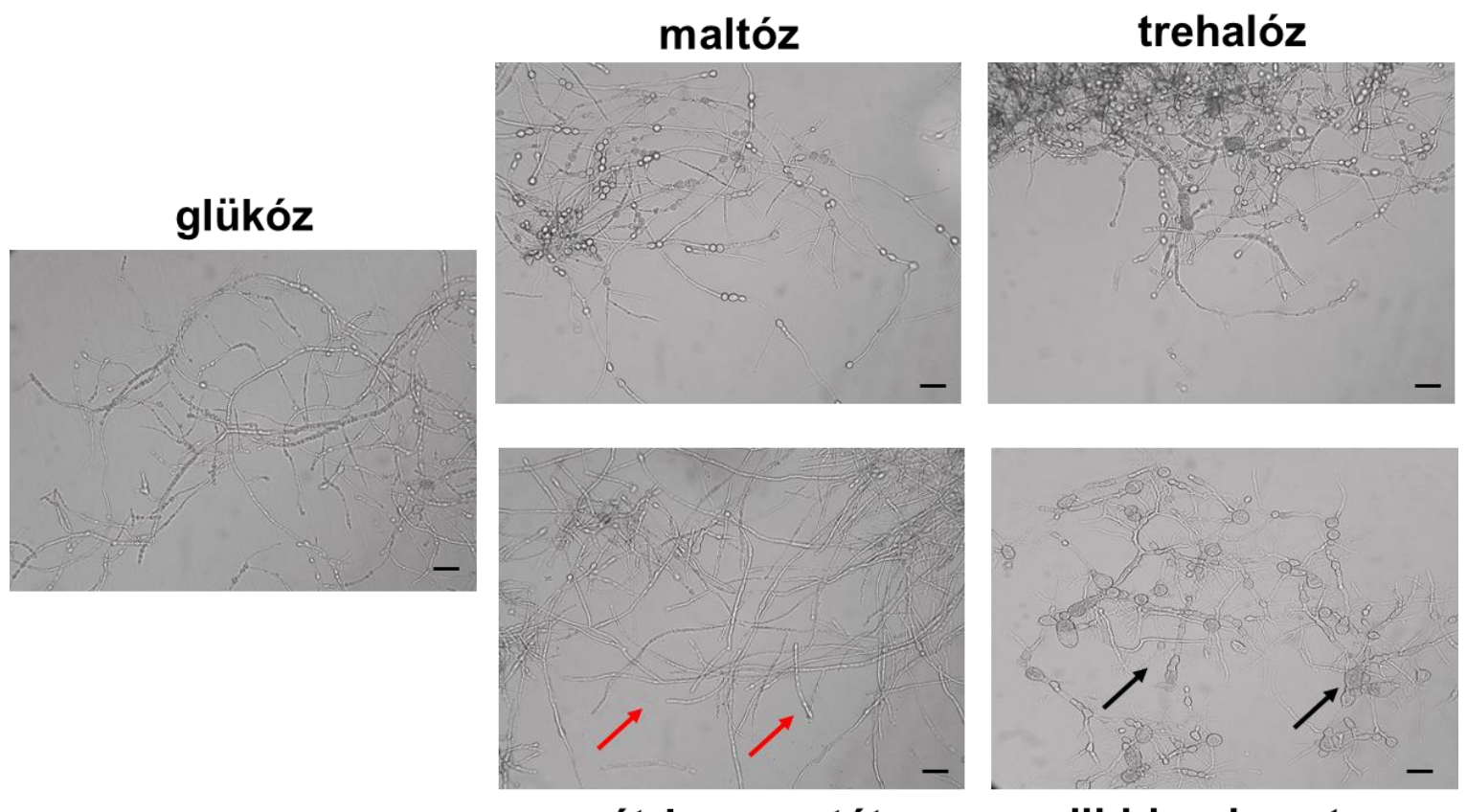

16. ábra. A M. circinelloides morfológiai változása a különböző szénforrásokon.

A morfológiai vizsgálathoz a törzset YNB tápoldatban tenyésztettük. A méretskála $10 \mu \mathrm{m}$-nek felel meg.

Mindhárom gén esetében magas relatív transzkripciós értéket mértünk nátrium-acetát és DHA szénforráson. Ugyanakkor $h m g R 2$ és $h m g R 3$ esetében a glükóz ugyancsak magas transzkripciós szintet eredményezett. A $M$. circinelloides esetében kimutatták, hogy a glükóz nagyon jó szénforrás a terpének bioszintéziséhez, köztük a karotinok termeléséhez (Papp és mtsi 2013; Mosquedo-Cano és mtsi. 1995). A hmgRl esetében a maltózon és a trehalózon mért érték nem különbözött szignifikánsan a glükózon mért értékhez képest, azonban DHAn jelentősen megnőtt. Ezzel szemben a $h m g R 2$ és $h m g R 3$ esetében a relatív tanszkripciós szint maltózon és trehalózon szignifikánsan lecsökkent, míg DHA-n nem változott (17. ábra).

A nátrium-acetát és a dihidroxi-aceton részt vesznek a glikolízis folyamatában és lehetséges prekurzorai a mevalonát útvonalnak. Feltehetőleg ezen prekurzorok jelenléte csökkenti a Mucor hmgR2 gén kifejeződésének mértékét. Blakesleea és Phycomyces esetében az acetát a Mucor-hoz hasonló hatással van a gomba karotin bioszintézisére (Kuzina és mtsi 2007). Borrelia burgdorferi esetében az acetát stimulálja a HmgR enzim aktivitását is (Van Laar és mtsi. 2012). Eredményeink azt mutatják, hogy Mucor esetében, az acetát mindhárom reduktáz gén müködésére a glükózhoz hasonló hatást gyakorol. 

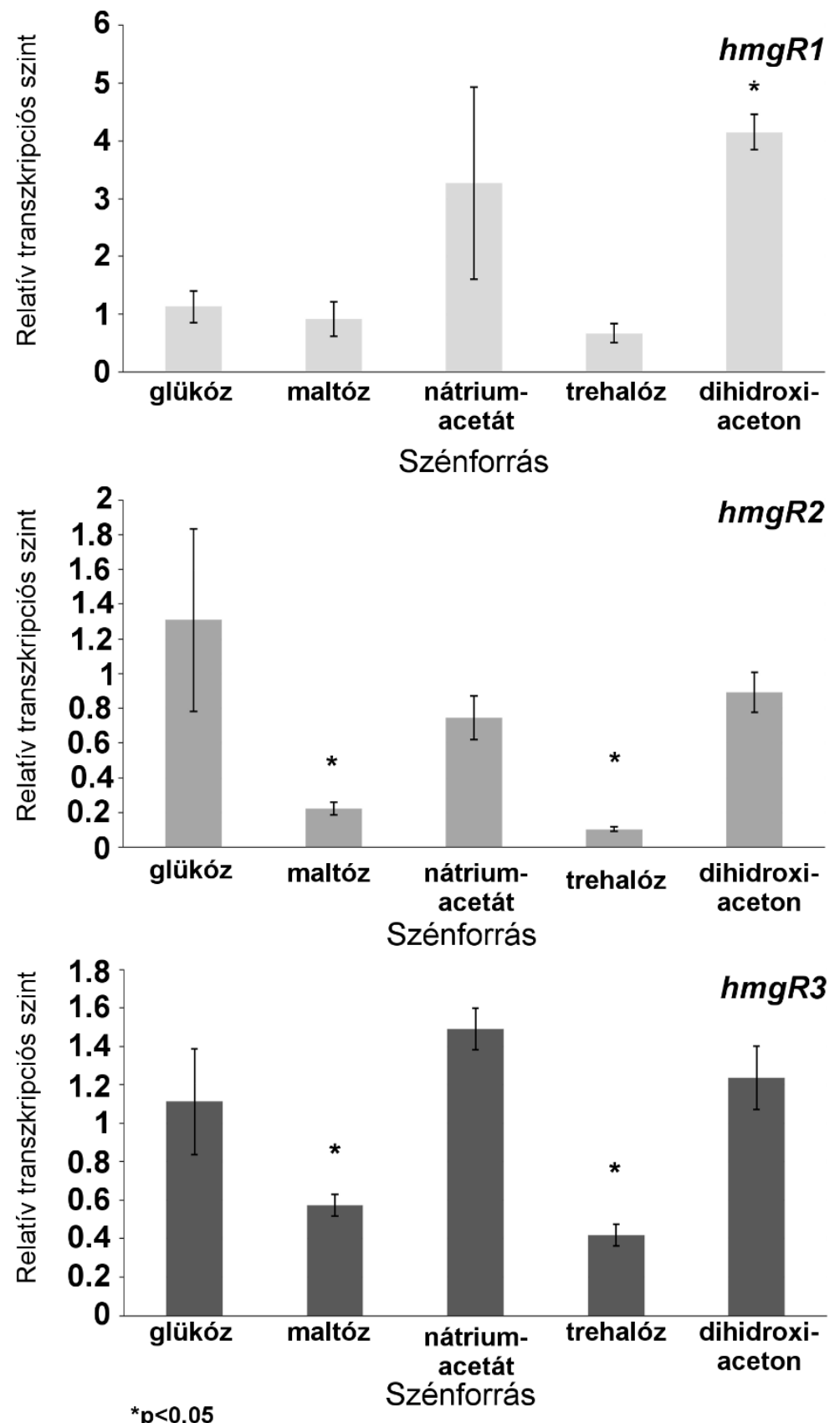

17. ábra. A $\boldsymbol{h} m g \boldsymbol{R}$ gének relatív transzkripciós szintjei különböző szénforrásokon

Mindegyik gén esetében a glükózon mért értékhez viszonyítottunk. A diagramon három egymástól független mérés eredményeinek átlagértékeit tüntettük fel szórással együtt, * jelzi a glükózon mért értéktől való

szignifikáns eltérést. A szignifikancia szint megállapításához párosított t-próbát végeztünk.

\subsubsection{A $h m g R$ gének relatív transzkripciós szintjei aerob és anaerob körülmények}

\section{között}

A $M$. circinelloides-re jellemző a morfológiai dimorfizmus képessége. Oxigén hiányos állapotban és/vagy magas hexóz koncentráció mellett a gomba fonalas növekedése reverzibilisen átvált élesztö-szerü morfológiára. Az oxigén hiányos állapotban kialakult élesztő-szerű sejtek ismét fonalas morfológiát vesznek fel, miután a tenyészet újra oxigén 
dús környezetbe kerül (18. ábra). Ez a váltás az oxigén megjelenését követő 45. perctől indul be.
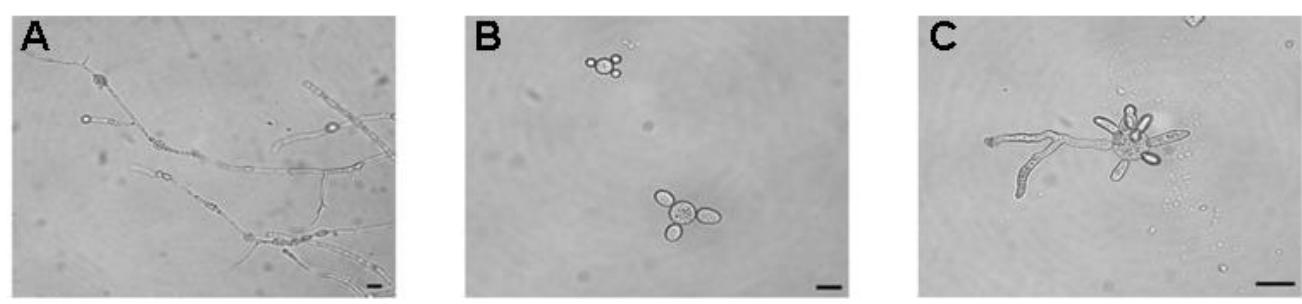

18. ábra. A M. circinelloides mikromorfológiája aerob és anaerob körülmények között.

Aerob körülmények között fonalas morfológiát mutat (A), mely reverzibilisen átvált élesztö-szerü morfológiává alacsony oxigén szint mellett (B). Aerob környezetben, 45 perc elteltével az élesztő-szerủ sejtek fonalakat kezdenek el növeszteni (C). A méretskála $10 \mu \mathrm{m}$-nek felel meg.

Az intenzív fonálképződés és a megváltozott oxigén ellátottság miatt fontosnak találtuk ebben az állapotban is megvizsgálni az egyes $h m g R$ gének transzkripciós szintjeit (19. ábra). A gomba morfológiai változásait a 18. ábrán láthatjuk. Négy napig anaerob körülmény között növesztve a törzset, a $h m g R l$ relatív transzkripciós szintje szignifikánsan lecsökkent, míg a $h m g R 3$ relatív transzkripciós szintje szignifikánsan megnőtt az aerob körülményen mérthez képest. A $h m g R 2$ esetében nem tapasztaltunk jelentős változást az aerob és anaerob körülményen mért relatív transzkripciók között. Újra oxigéndús környezetbe helyezve az anaerob tenyészetet az élesztö-szerü sejtek hifákat kezdtek el növeszteni. Ebben az állapotban a $h m g R l$ és $h m g R 2$ gén relatív transzkripciós szintje szignifikánsan megemelkedett, míg a $h m g R 3$ gén relatív transzkripciós szintje nem változott lényegesen az anaerob környezetben mért értékhez képest. Itt is egy intenzív micéliumképzés indul be, hasonlóan a spórák leoltásától eltett 8. órában (6.3.1. fejezet) és mind a két esetben megfigyelhető a $h m g R 2$ relatív transzkripciójának szignifikáns emelkedése. 

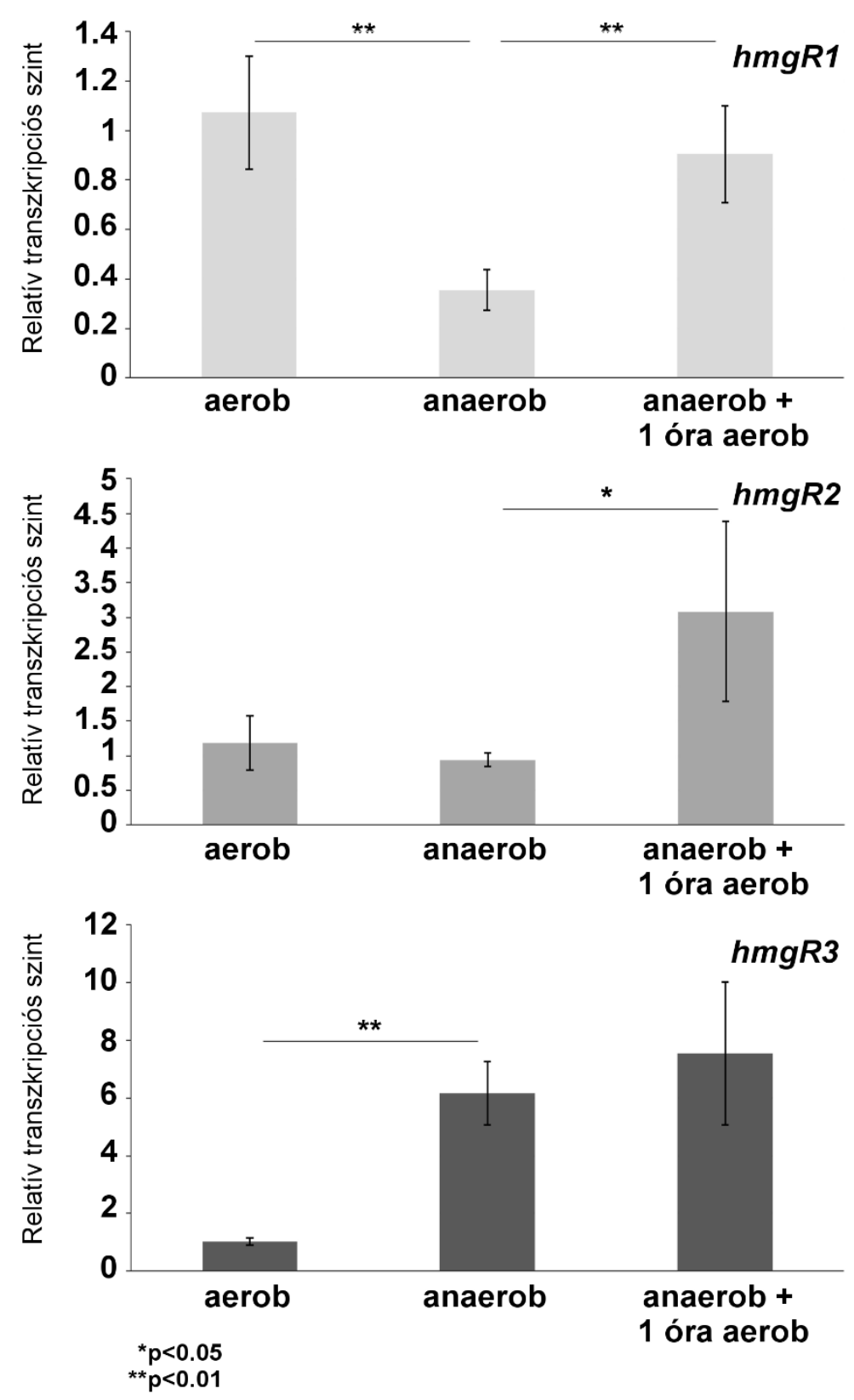

19. ábra. A hmgR gének relatív transzkripciós szintjei aerob és anaerob körülmények között Az eredményeket három egymástól független mérés után kaptuk, a szórás jelzi a mérések közötti eltéréseket. Mindegyik gén aerob körülményen mért értékéhez viszonyítottunk. A szignifikancia szint megállapításához párosított t-próbát végeztünk.

Amennyiben összevetjük a három reduktáz gén anaerob és aerob körülmények között mért relatív transzkripciós értékeit (20. ábra), általánosságban elmondhatjuk, hogy aerob körülmények között a $h m g R 2$ mutatja a legmagasabb relatív transzkripciós értékeket, míg a hmgRl a legalacsonyabbat az összes vizsgált körülményt figyelembe véve. Azonban, anaerob körülmények közt a $h m g R 3$ az, amelyik a legmagasabb relatív transzkripciós szintet mutatja. Az eredmények arra utalnak, hogy Mucor esetében a környezet oxigén szintje hatással van a $h m g R$ gének kifejeződésére. 


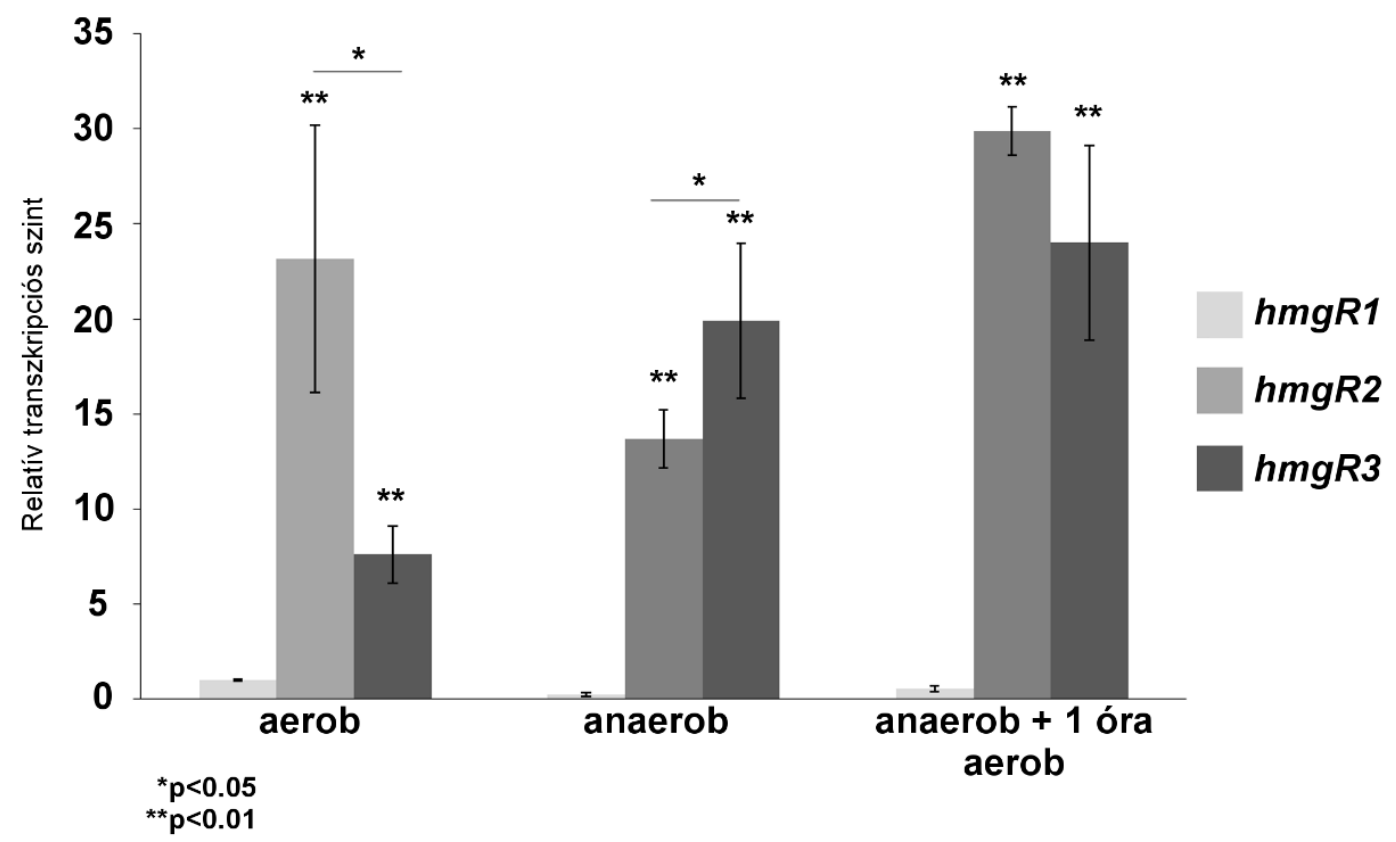

20. ábra. A M. circinelloides 3 hmgR génjének egymáshoz viszonyított relatív transzkripciós szintje aerob és anaerob körülmények között.

A $h m g R l$ aerob körülményen mért relatív transzkripciós szintjéhez viszonyítottunk. Az eredményeket három egymástól független mérés után kaptuk, a szórás jelzi a mérések közötti eltéréseket. A vízszintes vonalak jelzik a $h m g R 2$ és $h m g R 3$ gén relatív transzkripciójának szignifikáns különbségeit, míg az oszlopok feletti csillagok a $h m g R 1$ génhez viszonyított szignifikáns eltérésre utalnak. A szignifikancia szint megállapításához párosítatlan t-próbát végeztünk.

Az alacsony oxigén szint $h m g R$ géneket szabályzó szerepét korábban bizonyították S. cerevisiae-ben, Aspergillus fumigatus-ban, Cryptococcus neoformans-ban és Sch. pombeban is (Bien és mtsi. 2010). Eredményeink azt mutatják, hogy aerob körülmények között a M. circinelloides $h m g R 1$ és $h m g R 2$ kifejeződése erősebb, mint anaerob körülmények között. Ellenben a $h m g R 3$ relatív transzkripciós szintje anaerob körülmény között szignifikánsan megemelkedik. Ilyen oxigénfüggést a $S$. cerevisiae-nél is megfigyeltek, ahol a Hmg1p aerob körülmények között stabil, erős kifejeződést mutat, míg a Hmg2p kifejeződése gátolt. Anaerob körülmények között viszont a Hmg1p kifejeződése lecsökken, a Hmg2p-é pedig megnő (Burg és mtsi. 2011; Koning és mtsi. 1996).

\subsubsection{A relatív transzkripciós szint mérések legfontosabb eredményei}

Az 4. táblázatban a transzkripciós vizsgálatok legfontosabb eredményeit foglaltuk össze. Ezek szerint mind a három gén eltérő mértékben ugyan, de reagál a különböző környezeti ingerekre. Általánosságban elmondható, hogy a három reduktáz gén közül a $h m g R 1$ aerob környezetben, a $h m g R 3$ anaerob környezetben fejeződik ki leginkább, míg a $h m g R 2$ gén kifejeződése minden vizsgált körülmény mellett erőteljes volt. 
4. táblázat. A különböző tenyésztési körülmények hatása a $h m g R$ gének transzkripciójára.

\begin{tabular}{|c|c|c|c|c|}
\hline & & hmgR1 & hmgR2 & hmgR3 \\
\hline $\begin{array}{l}\text { Tenyésztési } \\
\text { körülmény }\end{array}$ & Kontroll & \multicolumn{3}{|c|}{ Legjelentősebb változások } \\
\hline $\begin{array}{c}\text { Tenyésztési } \\
\text { idő }\end{array}$ & 96.óra & $\begin{array}{l}\text { 4. órában nincs, } 48 . \\
\text { óában maximum }\end{array}$ & 8. órában maximum & 48. órában maximum \\
\hline Hőmérséklet & $25{ }^{\circ} \mathrm{C}$ & $\begin{array}{l}\downarrow\left(35^{\circ} \mathrm{C}\right) \\
\left(15 \text { és } 20^{\circ} \mathrm{C}\right)\end{array}$ & $\downarrow\left(30^{\circ} \mathrm{C}\right)$ & $\uparrow\left(20^{\circ} \mathrm{C}\right)$ \\
\hline Sóstressz & $\begin{array}{c}\mathbf{0 \%} \\
\mathrm{NaCl}\end{array}$ & † (1 és $3 \% \mathrm{NaCl}$ ) & † $\begin{array}{c}\text { (emelkedő } \mathrm{NaCl} \\
\text { párhuzentrációval }\end{array}$ & $\uparrow^{(1 \% \mathrm{NaCl})}$ \\
\hline Szénforrás & glükóz & dihidroxi-aceton) & I(maltóz, trehalóz) & I(maltóz, trehalóz) \\
\hline
\end{tabular}

A lefelé mutató nyíl a transzkriptum szint csökkenését, a felfelé mutató nyíl a transzkriptum szint növekvését jelzi a kontroll állapothoz képest.

A hmgRl alig fejeződik ki a spórák csírázásának idejében (a leoltástól számított 4. órában), maximumát a 48. órában éri el. Erős hőmérsékletfüggést tapasztaltunk kifejeződésében, valamint a sóstressz is befolyásolta a gén relatív transzkripcióját. A különböző szénforrások közül csak a DHA indukálta a gén átíródását. A $h m g R 2$ már igen magas relatív transzkripciós szintet ért el a spórák csírázásnak idején, azonban a kifejeződésének maximumát a leoltástól számított 8. órában, az intenzív micéliumképzés idején, érte el. A sóstressz hatására a gén relatív transzkripciós szintje megemelkedett. Maltózon és trehalózon a gén kifejeződése gátolt volt. A $h m g R 3$ szintén aktiválódik a spórák csírázásának idején, azonban a relatív transzkripciós szintjének maximumát a leoltástól számított 48. órában éri el. Jelentős oxigénfüggést tapasztaltunk a gén átíródásának vizsgálata során, ugyanis anaerob körülmények között megnő a gén relatív transzkripciós szintje. A szénforrások közül, ahogy a $h m g R 2$ kifejeződését is, a maltóz és a nátrium-acetát gátolta.

\subsection{A $h m g R$ gének funkcionális vizsgálata}

A hmgR gének funkcionális vizsgálatának céljából olyan vektorkonstrukciókat terveztünk, melyek lehetővé teszik az egyes gének túlmüködtetését, valamint a csendesítését. A kész plazmidokat $M$. circinelloides-be jutattuk és megvizsgáltuk, hogy az egyes gének kópiaszámának növelése (géndózis hatás), illetve csendesítése milyen hatással 
van a gomba terpén bioszintézisére, morfológiájára és sztatinokkal szembeni érzékenységére.

Korábbi vizsgálatok arra engednek következtetni, hogy az egyes terpenoidok szintézise egymástól elkülönülve, külön kompartmentekben történik (Bejarano és CredáOlmedo 1992; Kuzina és mts. 2006). Ennek érdekében szeretnénk azt is megvizsgálni, hogy M. circinelloides-ben az egyes $h m g R$ géneknek van-e valamelyik terpénszármazék bioszintézisére nézve specifikus szerepe.

\subsubsection{A hmgR gének túlmüködtetése}

Rendelkezésünkre állt egy gpdl promóter és terminális szakaszt hordozó vektor, a pPT43 (Papp és mtsi. 2006) és egy pyrG gént hordozó vektor a pPT81. A PCR reakció során felszaporított teljes $h m g R$ géneket egyenként pPT43 plazmidba klónoztuk PstI-NotI $(h m g R l)$ és SalI-NotI enzimek ( $h m g R 2$ és $h m g R 3)$ segítségével. Így olyan plazmidokat kaptunk, amelyek tartalmazták az egyes $h m g R$ géneket, a $g p d l$ terminális és promóter régiókat, valamint a bakteriális transzformáció során alkalmazott ampicillin rezisztencia gént. Az így kapott pPT43-hmgR1, pPT43-hmgR2, valamint a pPT43-hmgR3 plazmidokba beépítettük a pPT81 plazmidból kivágott pyrG gént, $S c a$ I és $K p n I$ enzimek segítségével, így létrehozva a pNG1 ( $h m g R 1$ gént tartalmazza), pNG2 (hmgR2 gént tartalmazza) és a pNG3 ( $h m g R 3$ gént tartalmazza) expressziós vektorokat (21. ábra).

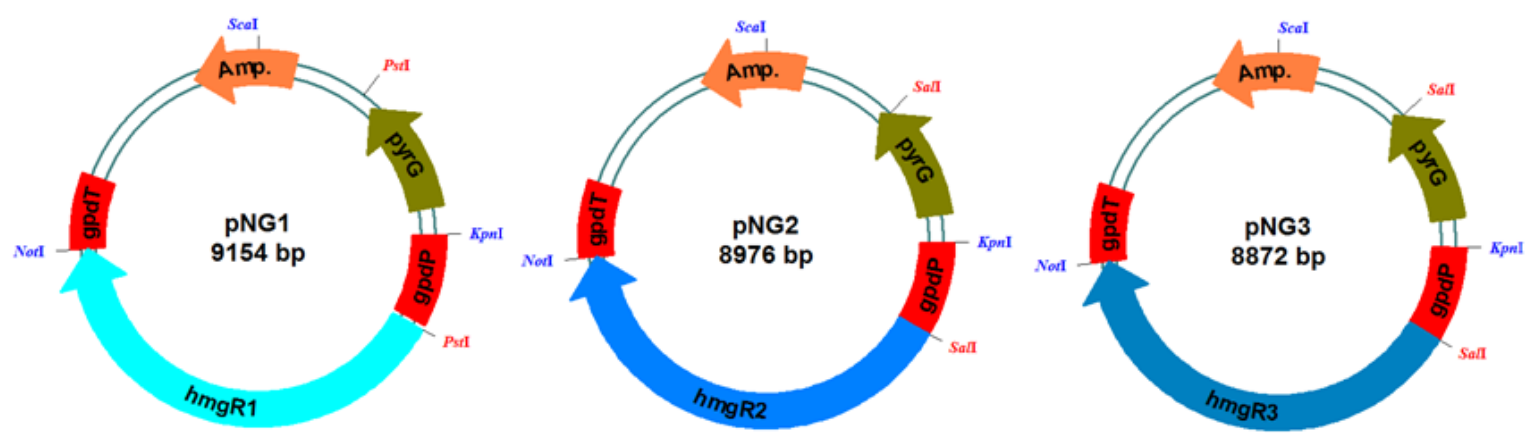

21. ábra. A M. circinelloides hmgR génjeinek túlmüködtetéséhez készített expressziós vektorok

Mindhárom vektorral sikeres PEG-mediált protoplaszt transzformációt hajtottunk végre az MS12 törzzsel. A transzformánsok szelektálását az uracil auxotrófia komplementálása alapján végeztük. A pNG1 és a pNG2 esetében 8 , míg a pNG3 esetében 6 transzformáns telepet kaptunk. 2-2 telep esetében qPCR segítségével megmértük a gének relatív transzkripcióját. Az MS12-pNG1 transzformánsok esetében a $h m g R l$ gén relatív transzkripciója mintegy tízszeresre, az MS12-pNG2 transzformánsok esetében a $h m g R 2$ gén relatív transzkripciója háromszázszorosra, míg az MS12-pNG3 transzformánsok esetében 
$h m g R 3$ gén relatív transzkripciója hetvenszeresre nött az MS12-ben mért értékekhez képest. Az egyes transzformánsokban a másik két gén relatív transzkripciós szintjében nem történt szignifikáns változás. A pNG1 vektort hordozó transzformánsokban a plazmid kópiaszáma 2-4, a pNG2 vektort hordozó transzformánsok esetében a plazmid kópiaszáma 7-8, míg a pNG3 vektort hordozó transzformánsok esetében a plazmid kópiaszáma 1-4 kópia/genom között mozgott.

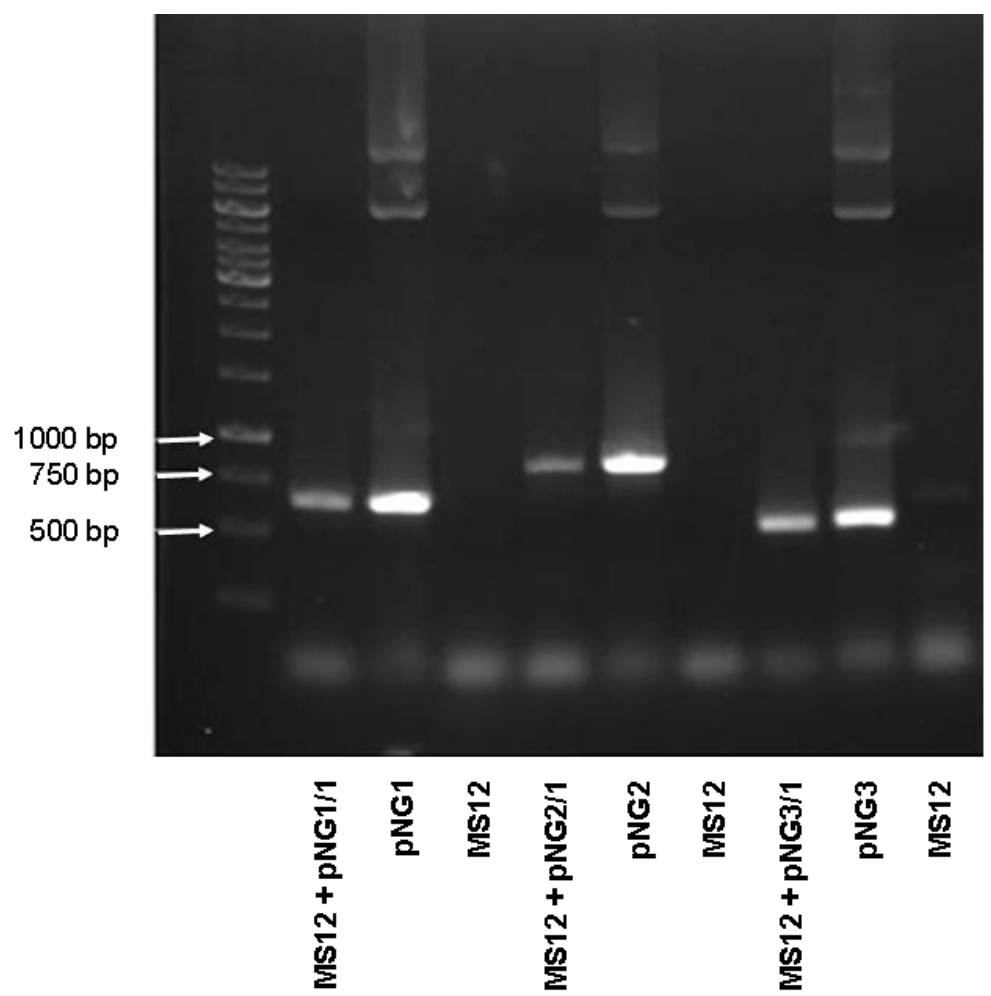

22. ábra. A pNG1, pNG2 és pNG3 plazmidok jelenlétének igazolása a transzformánsokban. A gpdP-re és az egyes $h m g R$ gének kezdeti szakaszára tervezett primerekkel végzett PCR kísérletek során a recipiens MS12 törzsből nem kaptunk amplifikációs terméket, míg a transzformánsokból (MS12+pNG1/1, MS12+pNG2/1, MS12+pNG3/1) és a kontrollként használt plazmidokból (pNG1, pNG2 és pNG3) igen.

A plazmidokat a gomba autonóm replikatív módon tartotta fenn. A transzformánsokban a plazmid jelenlétét PCR reakció segítségével mutattuk ki. A reakcióhoz a $g p d$ promóter végére és az egyes reduktáz gének elejére tervezett primereket használtuk. A PCR reakciók során a recipiens MS12 törzsből nem kaptunk PCR terméket, míg a kontrollként használt plazmidokból és a transzformánsokból igen (22. ábra), ezzel igazolva a plazmidok jelenlétét a transzformánsokban. Mindhárom transzformációs kísérlet után 2-2 transzformánst kiválasztottunk és a továbbiakban ezeket vizsgáltuk részletesebben.

\subsubsection{A hmgR gének csendesítését lehetővé tevő vektorkonstrukciók építése}

Az egyes $h m g R$ gének csendesítését antiszensz RNS (asRNS) technikával valósítottuk meg. Rendelkezésünkre állt a korábban említett pPT81 plazmid, melybe a 
bejutatott génszakaszokat a $g p d$ promóter és terminális szakaszok közé építettük be, fordított orientációban, a NotI-XhoI hasítóhelyek közé, így létrehozva a pAS1, pAS2 és pAS3 vektorokat (23. ábra). A hmgRl esetében a csendesítéshez használt szakasz 661 bp (a gén 5' végétől számított 29-630 nukleotid), a $h m g R 2$ esetében 625 bp (a gén 5' végétől számított 21-646 nukleotid) és a hmgR3 esetében 697 bp (a gén 5' végétől számított 51-748 nukleotid) hosszú volt.
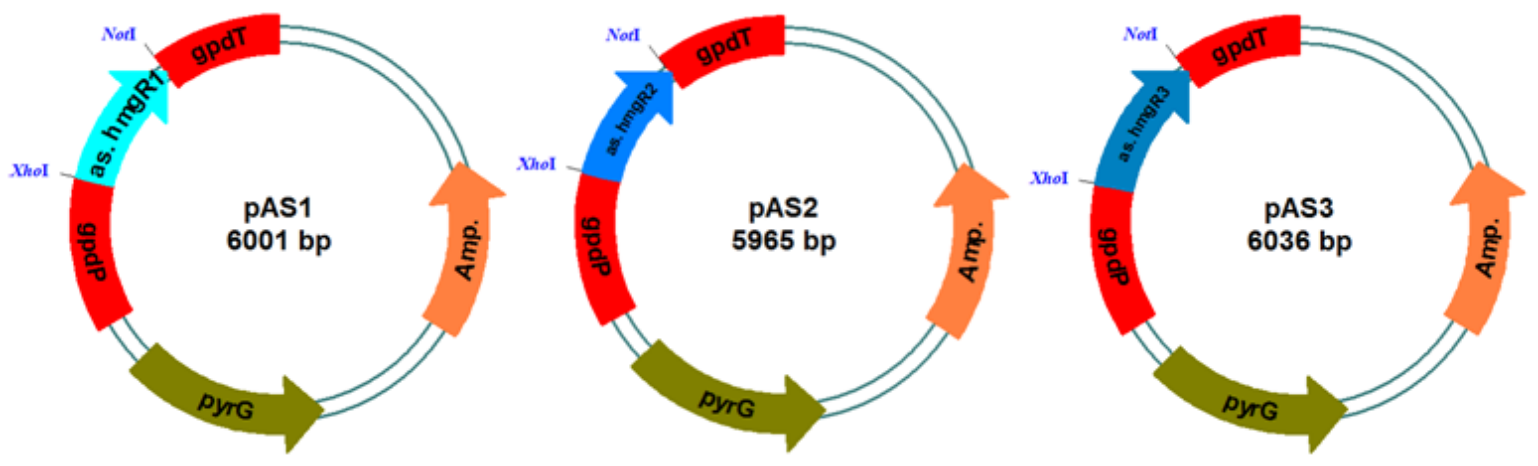

23. ábra. A M. circinelloides hmgR gének csendesítéséhez szerkesztett vektorok.

A létrehozott vektorokkal (23. ábra) sikeres PEG-mediált protoplaszt transzformációt hajtottunk végre az MS12 törzzsel.

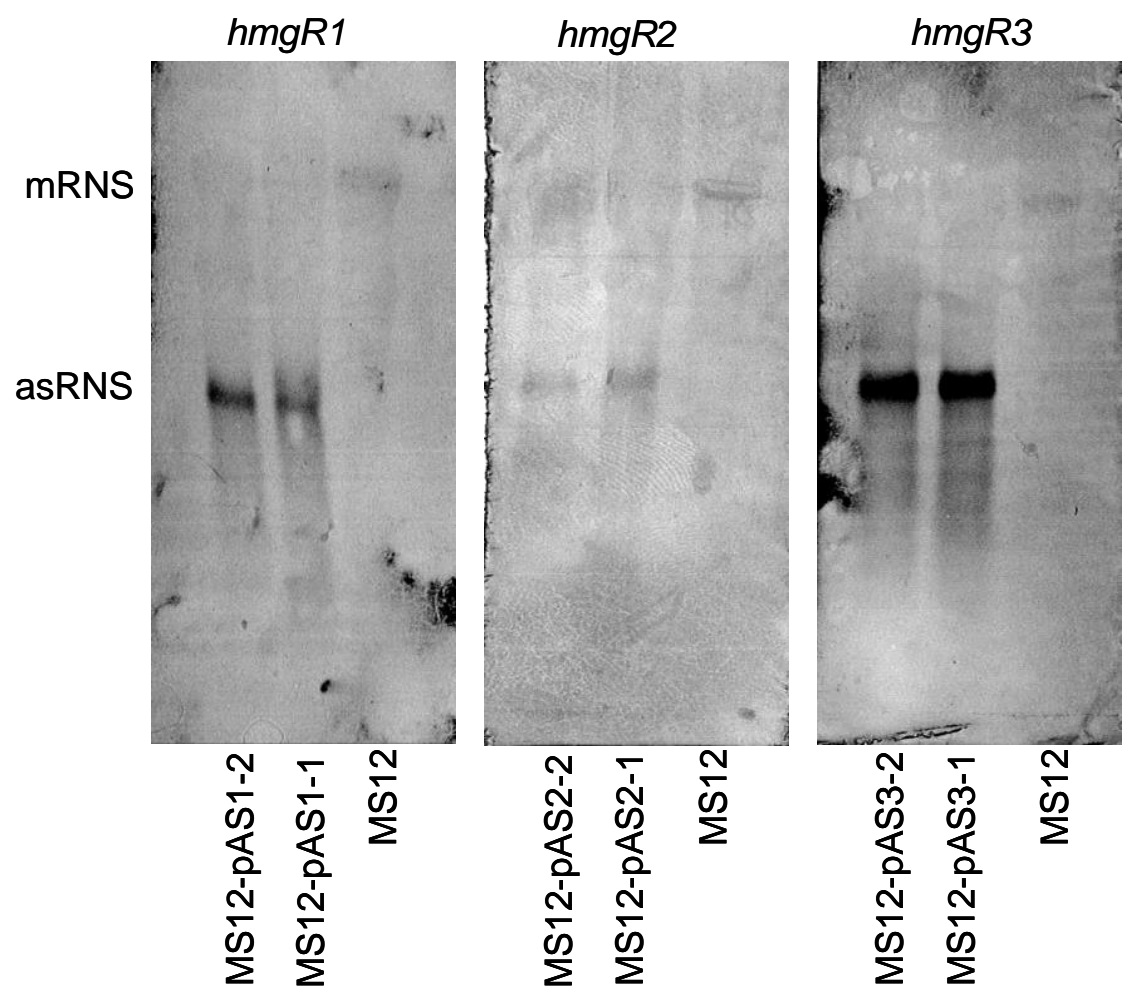

24. ábra. Az asRNS kimutatása Northern hibridizációval.

A pAS1 és pAS3 vektorral transzformálva 6-6, míg a pAS2 vektorral transzformálva 3 transzformáns telepet kaptunk. A plazmidok fennmaradása érdekében a transzformánsok 
tenyésztését szelektív körülmények közt végeztük. A plazmidokat a gomba autonóm replikatív módon tartotta fel. A transzformánsokból Northern-hibridizáció segítségével mutattuk ki a plazmidról átíródó asRNS molekulákat (24. ábra). A csendesítés hatékonyságát transzformációs kísérletenként két-két transzformáns esetében qPCR segítségével vizsgáltuk. Az egy transzformációs kísérletből származó, különböző transzformánsokban eltérő volt a csendesítési hatékonyság, feltételezhetően a bejuttatott plazmidok kópiaszmának és kifejeződésének eltérései miatt. A $h m g R l$ gén relatív transzkripciós szintje az egyes csendesített transzformánsokban 70, illetve 90\%-kal, a $h m g R 2$ gén relatív transzkripciós szintje 75 és $76 \%$-kal, míg a $h m g R 3$ gén relatív transzkripciós szintje 59 és 95\%-kal csökkent az MS12-ben mért értékhez képest. A további vizsgálatok során, minden gén esetében e két-két izolátumot elemeztük és azok eredményeit ábrázoltuk (25-27. ábra és 5,6 . táblázat). A fénymikroszkópos felvételeken a legnagyobb csendesítési hatékonyságot mutató törzsek láthatók (28-36. ábra).

\subsubsection{A mutáns törzsek növekedésének vizsgálata}

A túlmüködtetett és csendesített transzformánsok előállítását és a transzformáció sikerességének igazolását követően megkezdtük a törzsek növekedési képességének a vizsgálatát. A spórák csírázási képességének meghatározásához a telepekről steril desztillált vízzel lemostuk a spórákat, majd $30 \mathrm{ml}$ YNB tápoldatba oltottuk azokat úgy, hogy a spórakoncentrációt minden esetben $10^{5} \mathrm{spóra} / \mathrm{ml}$-re állítottuk be. A spórák csírázásának szinkronizálása céljából a beoltott tápoldatokat egy éjszakán keresztül $4{ }^{\circ} \mathrm{C}$-on tartottuk, majd másnap $25{ }^{\circ} \mathrm{C}$-on, $200 \mathrm{rpm}$ sebességgel rázattuk. Óránkénti mintavételezéssel vizsgáltuk a megjelenő csíratömlőket. A telepátmérő növekedésének vizsgálatához szilárd YNB táptalaj közepére $10^{5}$ spórát cseppentettünk, amit steril fülke alatt beszárítottunk. A leoltástól számítva 4 napon keresztül vizsgáltuk a növekvő telepek átmérőjét. A megfigyelést minden gén esetében két túlmüködtetett és két csendesített transzformánssal, három-három párhuzamosban végeztük és azok átlagát ábrázoltuk a diagramokon. Kontrollként a $M$. circinelloides MS12 törzsét használtuk.

A 25. ábrán látható a $h m g R l$ gént túlmüködtető (MS12-pNG1) és csendesített (MS12-pAS1) mutánsok növekedési rátája. A csíratömlők megjelenése mind a csendesített (MS12-pAS1), mind a túlmüködtetett (MS12-pNG1) izolátumok esetben a leoltástól számított 4. órában jelent meg, mint a vad típusú törzs esetében. Emellett az egyes transzformáns törzsek növekedésében és a telepátméröikben sem tapasztaltunk jelentősebb változást az MS12-höz képest. 


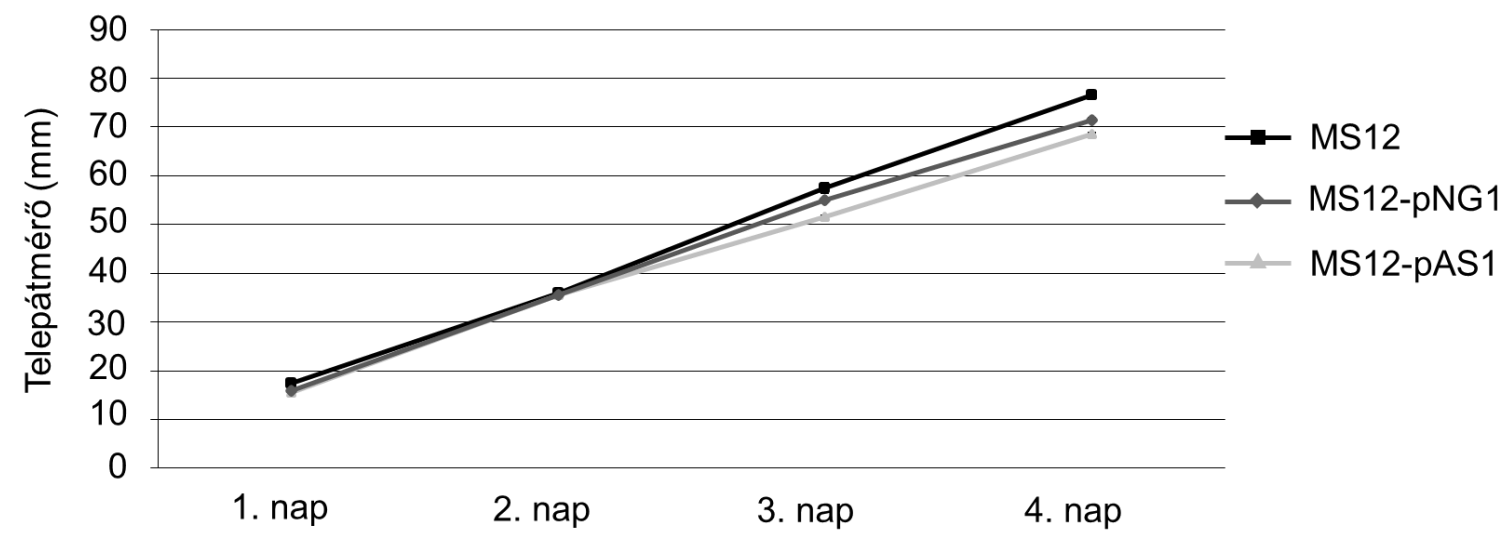

25. ábra. A hmgR1 gén túlműködtetésének (MS12-pNG1 transzformánsok) és csendesítésének (MS12pAS1 transzformánsok) hatása a gomba növekedésére.

A hmgR2 gén túlmüködtetésének (MS12-pNG2) és csendesítésének (MS12-pAS2) hatására nem tapasztaltunk változást a gomba növekedési rátájában (26. ábra). Az MS12pNG2 izolátumok spóráinak csírázási ideje megegyezett az MS12 spóráinak csírázási idejével, azonban a gén csendesítésének hatására az MS12-pAS2 izolátumok spóráinak csírázási ideje a leoltástól számított 4. óráról az 5. órára tolódott ki.

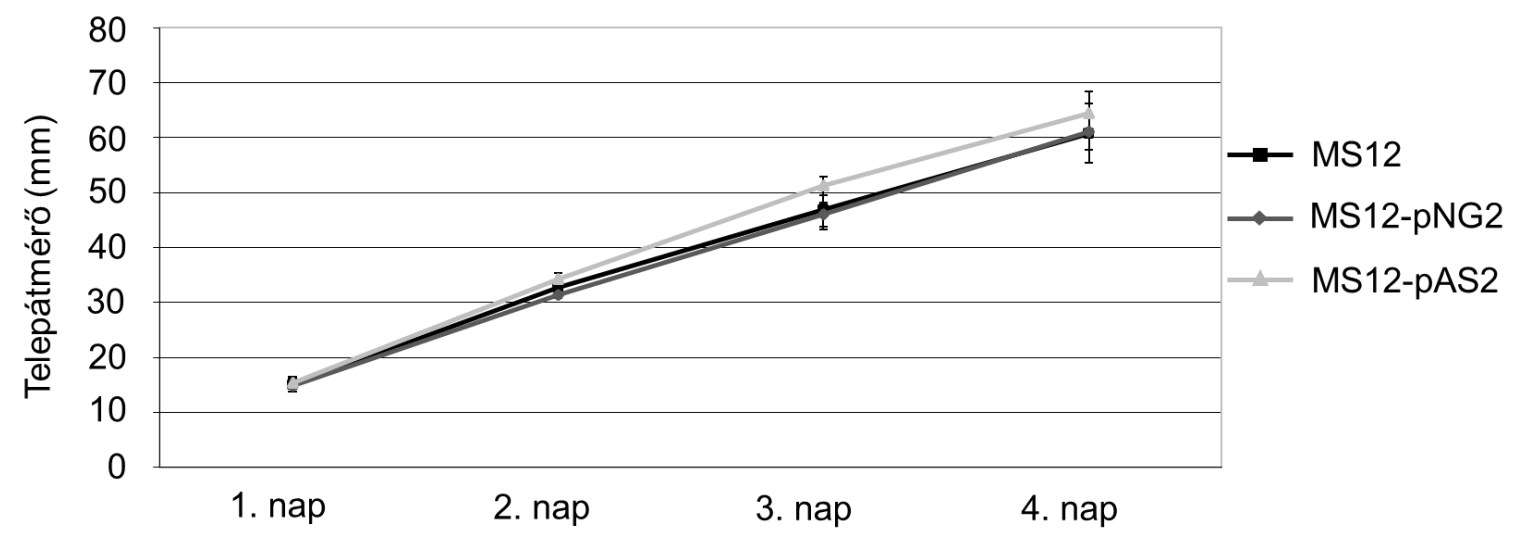

26. ábra. A hmgR2 gén túlműködtetésének (MS12-pNG2 transzformánsok) és csendesítésének (MS12pAS2 transzformánsok) hatása a gomba növekedésére.

A hmgR3 gén túlmüködtetésének hatására a transzformánsok (MS12-pNG3) esetében nagyobb telepátmérőt mértünk az MS12-höz képest, azonban ezen transzformáns törzsek spóráinak csírázási ideje nem változott. A gén csendesítése során azonban a transzformánsok (MS12-pAS3) növekedési sebessége és telepátmérője lecsökkent (27. ábra). A spórák csírázóképességének vizsgálata során azt tapasztaltuk, hogy a pAS3 vektort hordozó izolátumok spóráinak csírázó képessége lecsökkent. Ezen izolátumok spóráinak csírázási ideje a leoltástól számított 4. óráról a 8. órára tolódott ki. A folyadéktenyészetben történt nevelés során feltünt, hogy még a leoltástól számított 4. napon is nagyszámú ki nem csírázott spóra volt jelen a tápoldatban. 


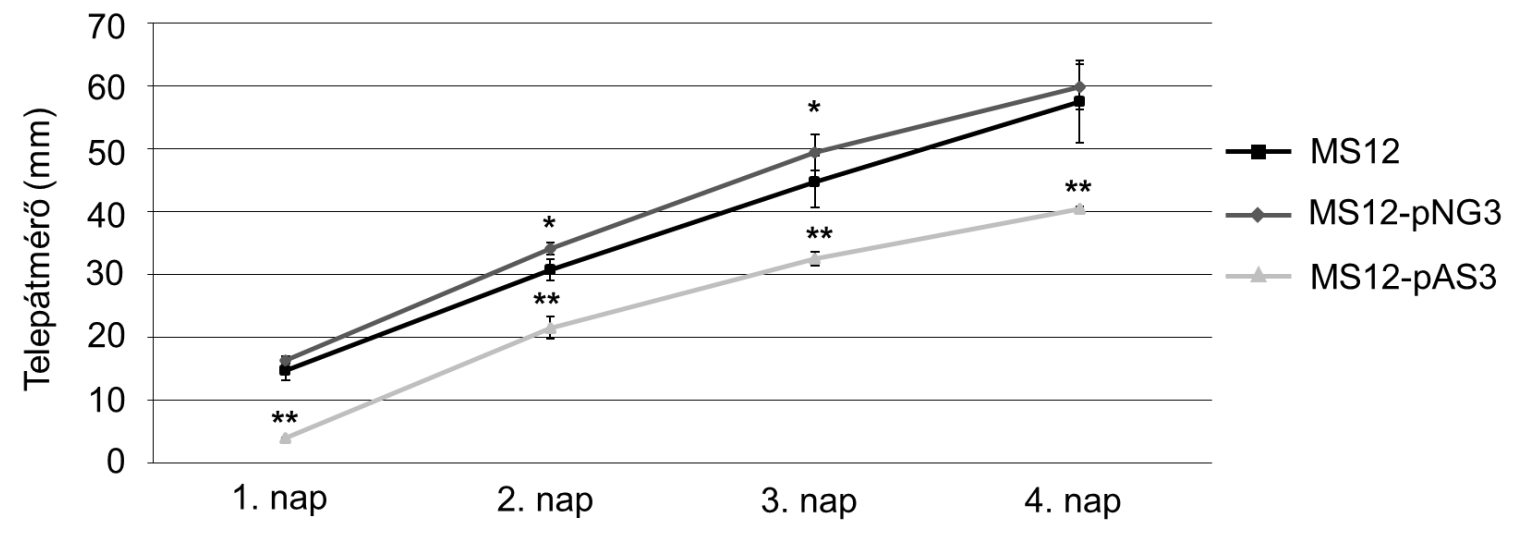

27. ábra. A hmgR3 gén túlmúködtetésének (MS12-pNG3 transzformánsok) és csendesítésének (MS12pAS3 transzformánsok) hatása a gomba növekedésére.

Az MS12 esetében mért értéktől való szignifikáns eltérést a ${ }^{*} \mathrm{p}<0,05$ és $*{ }^{*} \mathrm{p}<0,01$ jelzi. A szignifikancia szint mérésére párosítatlan t-próbát végeztünk.

Eredményeink azt mutatják, hogy az egyes gének túlmüködtetése nem befolyásolja a gomba növekedési sebességét és a képződő telep átmérőjét. $F$. graminearum HMG-KoA reduktáz gén mutációjának hatására a mutáns törzs növekedése lelassult és csökkent virulenciát mutatott búzával szemben (Seong és mtsi. 2006). A Mucor $h m g R 3$ gén csendesítésének hatására a transzformáns törzsek növekedése a Fusarium-nál tapasztaltakhoz hasonlóan lecsökkent. S. cerevisiae-ben ismert, hogy a HMG-KoA reduktáznak fontos szerepe van a spórák csírázásában és a vegetatív sejtek növekedésében (Bason és mtsi. 1986). Eredményeink arra utalnak, hogy Mucor-ban a három HMG-KoA reduktáz közül HmgR3-nak lehet jelentősebb szerepe a spórák csírázásában és a vegetatív sejtek növekedésében.

\subsubsection{A $h m g R$ gének túlmüködtetésének és csendesítésének hatása transzformáns törzsek makro- és mikromorfológiájára}

A makro- és mikromorfológia vizsgálatához a transzformáns törzseket YNB táptalajon növesztettük 4 napig $25{ }^{\circ} \mathrm{C}$-on. A vizsgálathoz a szilárd táptalaj közepére $20 \mu 1$ spóraszuszpenziót cseppentettünk, mely $10^{5}$ spórát tartalmazott, majd figyeltük a növekvő gombatelepek morfológiáját. Kontrollként az MS12-t használtuk. A transzformáns telepek közül 2-2 izolátumot vizsgáltunk, azonban csak egy-egy csészefotót tüntettem fel. A mikromorfológiai vizsgálatokat fénymikroszkóppal végeztük, amihez a felnövő telepek széléről steril szike segítségével vágtuk ki a mintául szolgáló telepdarabokat. 


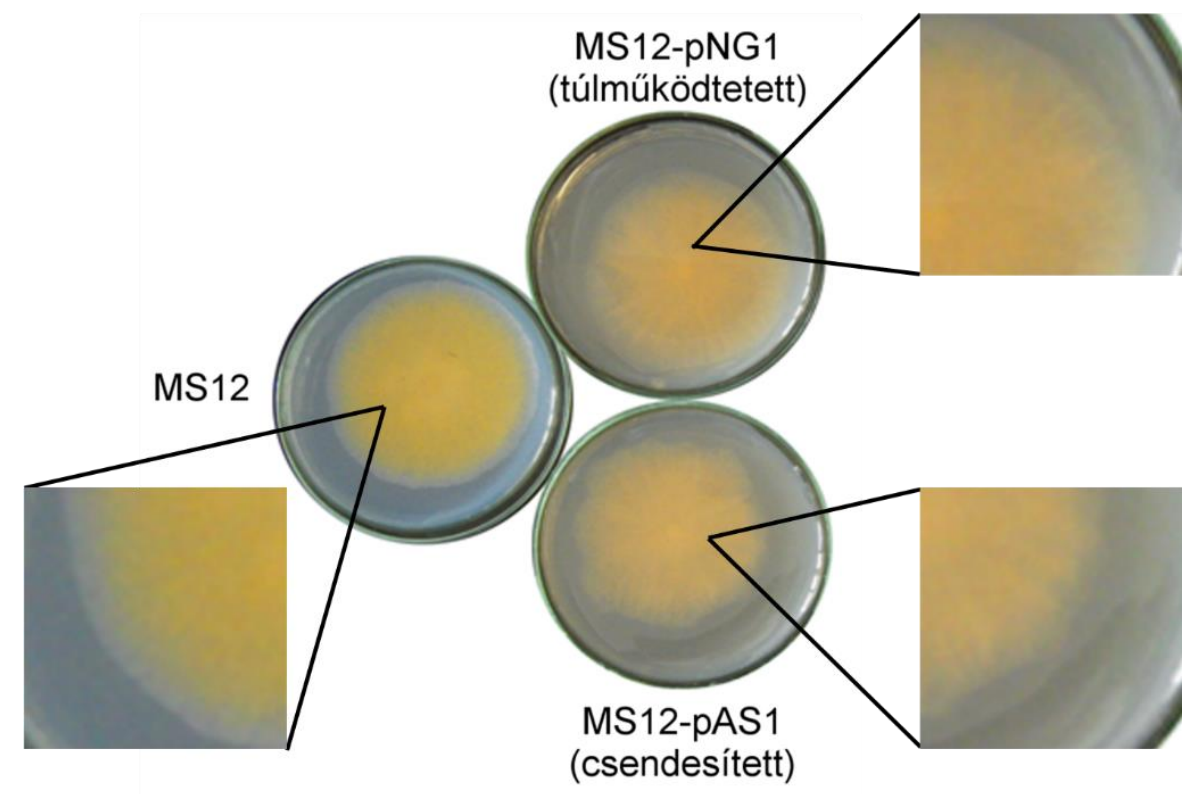

28. ábra. Az MS12, MS12-pNG1 és MS12-pAS1 törzsek telepmorfológiája

A hmgRl gén túlmüködtetésének és csendesítésének hatására az MS12-pNG1 és MS12-pAS1 izolátumok telepmorfológiájában nem tapasztaltunk jelentős változást az MS12-nél tapasztaltakhoz képest (28. ábra). Mindkét transzformáns izolátum szabályos telepmorfológiát mutat, a telepek széle kissé karéjozott.

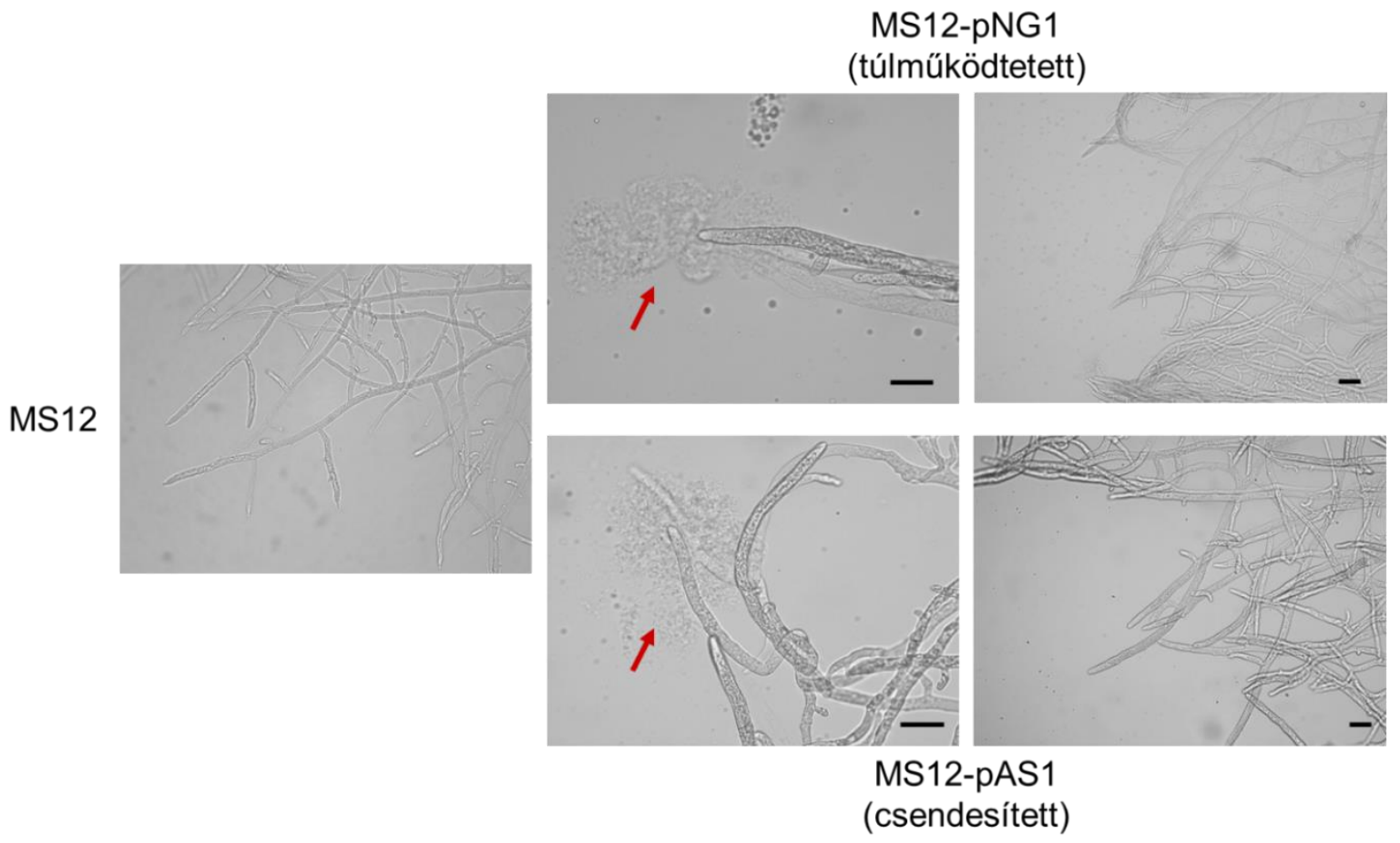

29. ábra. Az MS12, MS12-pNG1 és MS12-pAS1 izolátumok fénymikroszkópos képe.

A méretskála $10 \mu \mathrm{m}$-nek felel meg. A piros nyilak a plazmakiáramlásokat mutatják.

A telepek homogén szerkezetűek és, ahogy az ábrán is látható közel azonos méretű telepátmérővel rendelkeznek, mint az MS12. 
Az MS12-pNG1 és MS12-pAS1 transzformánsok esetében, a telepek fénymikroszkópos tanulmányozása során plazmakiáramlásokat figyeltünk meg a hifavégeken (29. ábra). A plazmakiáramlásokon kívül mikromorfológiai eltérést nem tapasztaltunk a vad típusú törzshöz képest. A hifák vékonyak, megnyúltak valamint kevés elágazást tartalmaznak, mint az MS12 esetében. A plazmakiáramlások valamilyen sejten belüli folyamat zavarára és/vagy a sejtmembrán, vagy a sejtfal szerkezetében bekövetkezett változásra utalnak. Hasonló plazmakiáramlásokat az MS12 esetében nem találtunk.

A $h m g R 2$ gén túlmüködtetésének és csendesítésének hatására az MS12-pNG2 és MS12-pAS2 izolátumok telepmorfológiájában sem tapasztaltunk jelentős változást az MS12-nél tapasztaltakhoz képest (30. ábra). Mindkét transzformáns esetén a szabályostól kissé eltérő telepmorfológiát találtunk, a telepek széle kissé karéjozottá vált. A micéliumtömeg ezeknél a transzformánsoknál is homogén szerkezetü, eltérő színű és mintázatú szektorokat nem találtunk.

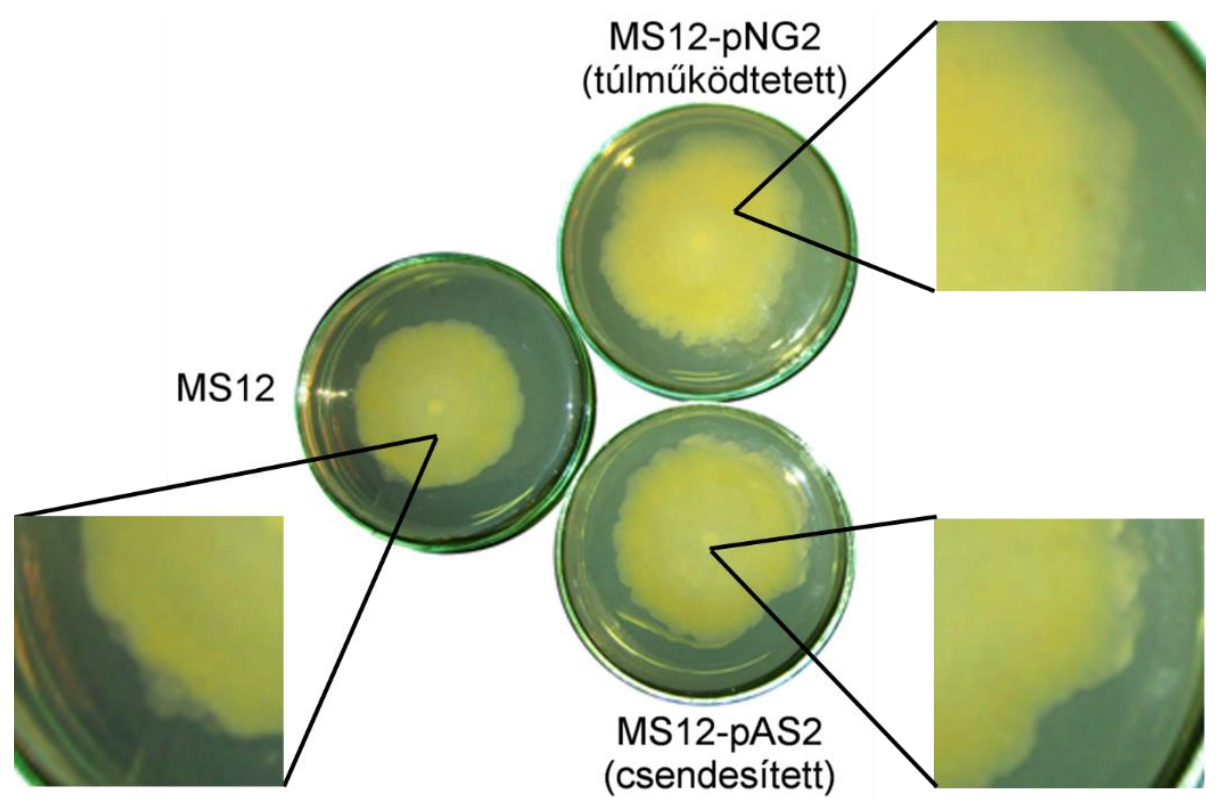

30. ábra. Az MS12, MS12-pNG2 és MS12-pAS2 törzsek telepmorfológiája.

A 31. ábrán látható, hogy az MS12-pAS2 transzformáns fénymikroszkópos vizsgálata során plazmakiáramlásokat figyelhetünk meg, viszont a túlmüködtetett mutánsnál ilyet nem tapasztaltunk. A végálló hifák makromorfológiája ezekben a mutánsokban sem változott meg. A hifák szabályos szerkezetủek, az elágazások számában és a hifák vastagságában nem következett be változás. 


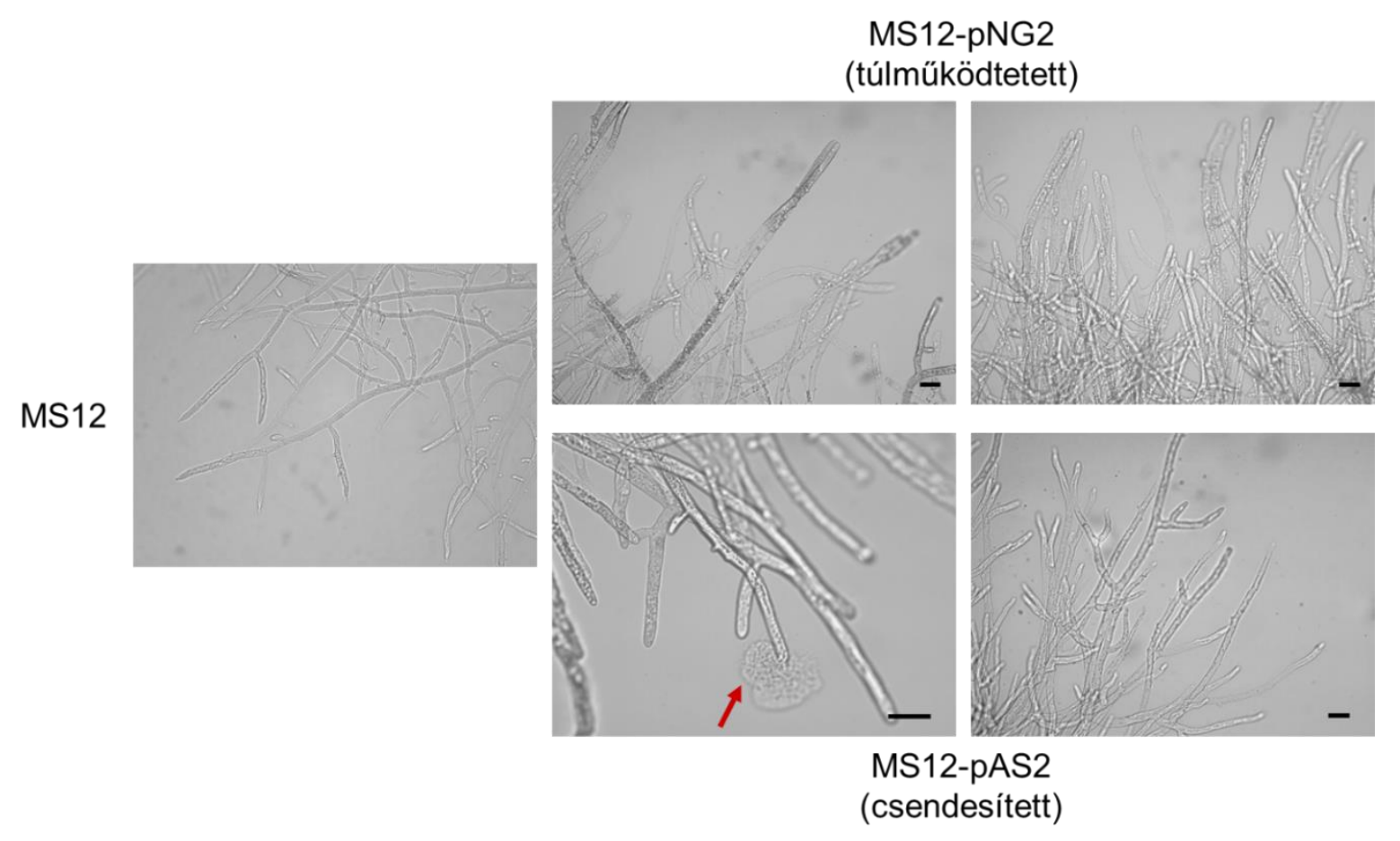

31. ábra. Az MS12, MS12-pNG2 és MS12-pAS2 izolátumok fénymikroszkópos képe. A méretskála $10 \mu \mathrm{m}-n e k$ felel meg. A piros nyíl a plazmakiáramlásokat mutatja.

A 32. ábrán látható, hogy a $h m g R 3$ gén túlmüködtetésének hatására a gombatelep nagysága, szabályos formája megváltozott, a telep széle karéjozottá vált.

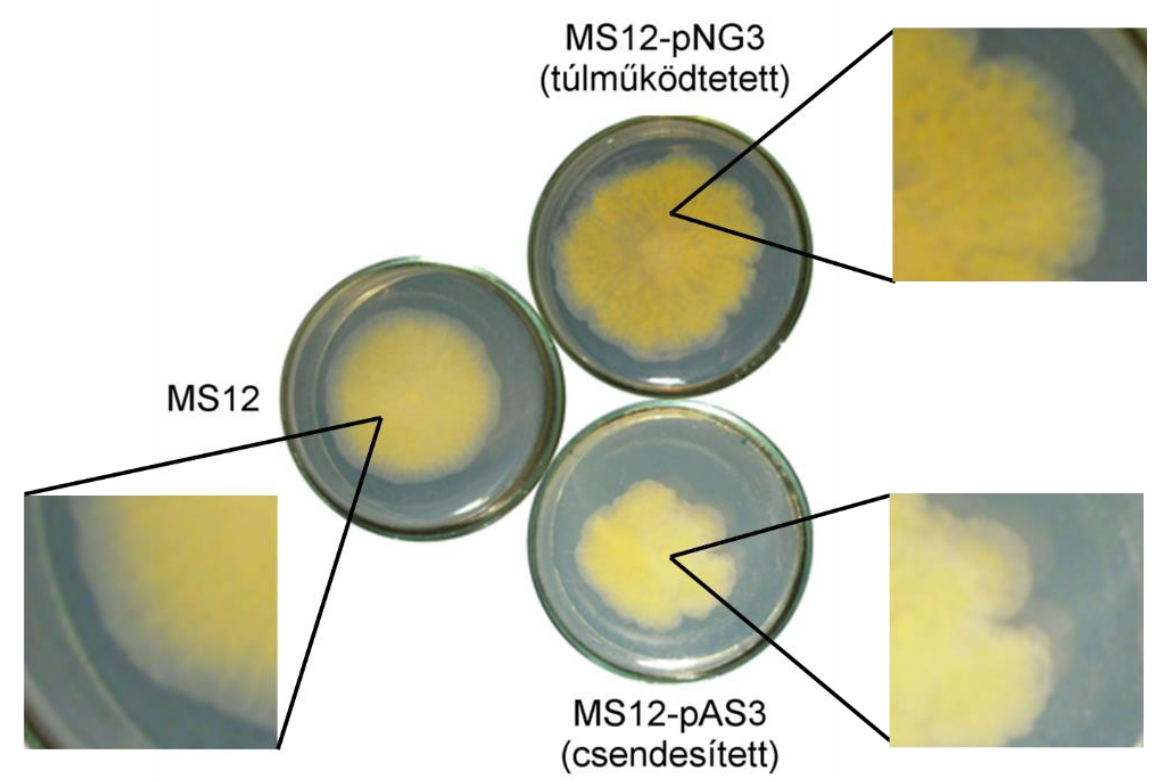

32. ábra Az MS12, MS12-pNG3 és MS12-pAS3 törzsek telepmorfológiája.

A gén csendesítésének hatására a telep morfológiai változása még ennél is szembetűnőbb. A leoltástól számított 4. napon a telepátmérő kisebb, mint az MS12 esetében, valamint a telep karéjozottsága sokkal szembetünőbb. Az MS12-pAS3 transzformánsok növekedési rátájának vizsgálata során is tapasztaltuk, hogy a $h m g R 3$ gén csendesítésének 
hatására csökkent e törzsek növekedése és ezzel együtt a gombatelep átméröje (6.4.3. fejezet) A micéliumtömeg nem egységesen homogén, hanem különböző szektorokat figyelhettünk meg, melyek színe a fehértől az erős sárgáig változott. Ezen szektorok karéjozottságában is eltéréseket tapasztaltunk. A mikromorfológiai vizsgálatokhoz a mintákat úgy választottuk ki, hogy a fehér és a sárga szektor mikromorfológiáját is meg tudjuk vizsgálni.

Az MS12-pNG3 transzformánsok esetében jelentős változásokat nem tapasztaltunk a hifák morfológiájában, azonban az MS12-pAS3 törzsek esetében a végálló hifák megduzzadtak, a hosszuk lerövidült és megnőtt az elágazások száma (33. ábra). Ezek a változások leginkább azokon a területeken voltak megfigyelhetők, ahol megjelentek fehér szektorok a micéliumtömegben. A színtelen szektorokban feltehetőleg e változások hatására a gomba nem tudott tovább növekedni. Az ép, sárga színü területeken a végálló hifák ugyan megvastagodtak, de nem rövidültek meg, azonban ezeken a területeken számos plazmakiáramlást láthattunk.

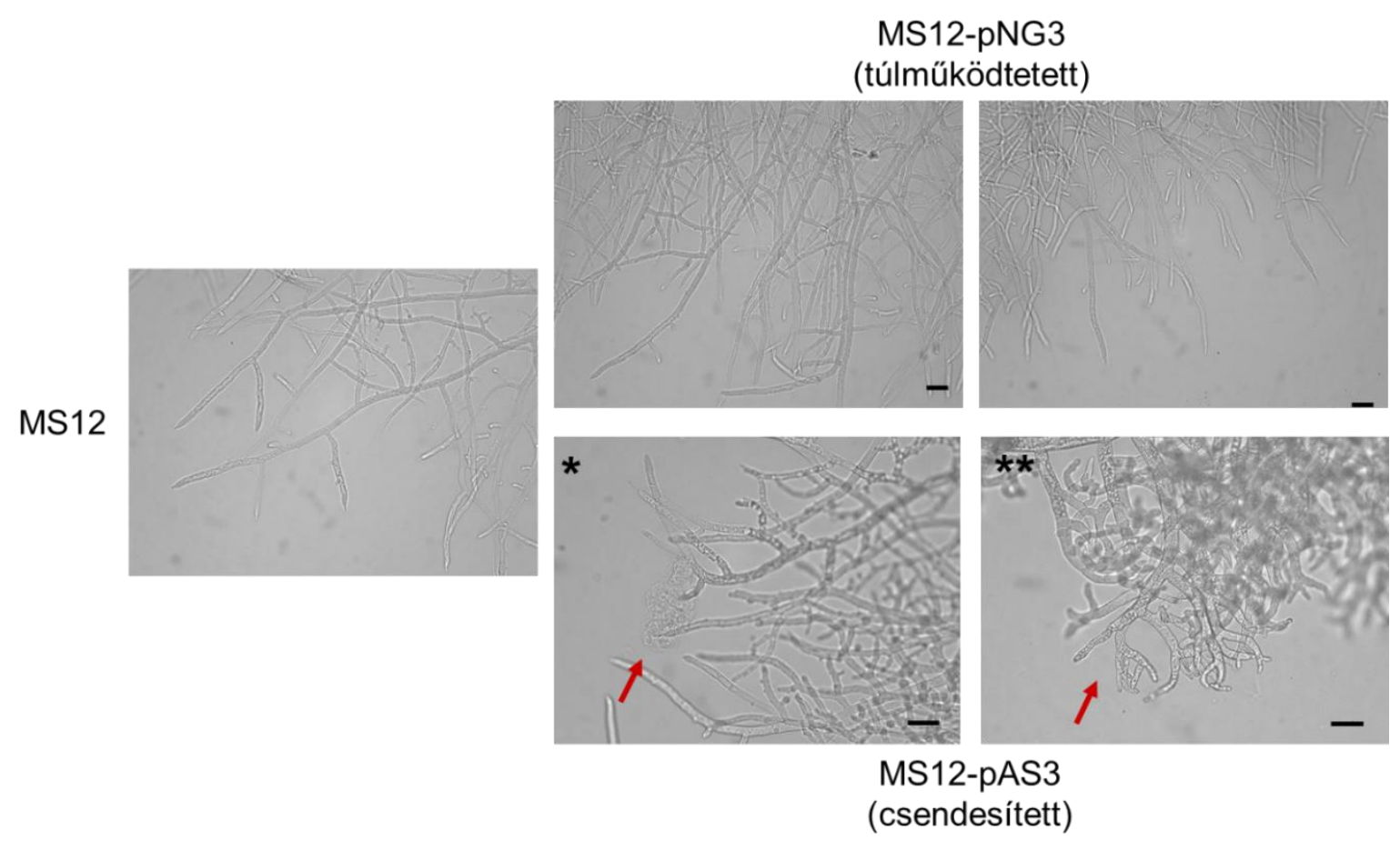

33. ábra. Az MS12, MS12-pNG3 és MS12-pAS3 izolátumok fénymikroszkópos képe.

Az MS12-pAS3 izolátum esetében a *-al jelölt minta egy sárga, alig karélyozott szektorból való, míg a **-al jelölt minta egy fehér, erősen karélyozott szektorból való. A méretskála $10 \mu \mathrm{m}$-nek felel meg. A piros nyilak a plazmakiáramlásokat mutatják.

Ezen változások egyik lehetséges magyarázata a transzformáció során bejutatott plazmid eltérő eloszlása a micéliumokban. Azokban a szektorokban, ahol fokozott zavar következett be a növekedésben és/vagy a hifák mikromorfológiájában valószínüleg a 
csendesítési hatékonyság magasabb, mint az ép teleprészekben. A bejuttatott plazmidok eltérő eloszlását Absidia-ban is megfigyelték, ahol génexpressziós vizsgálatokhoz $g f p$-t használtak. A transzformációt követően a GFP eloszlása nem volt homogén. Bizonyos szektorokban megjelent, míg más szektorok elvesztették a plazmidot (Schilde és mtsi. 2001).

Az MS12-pAS3 transzformánsokra ezen változásokon kívül jellemző volt, hogy a spóráinak csírázó képessége lecsökkent. Nem csak a csíratömlö megjelenésének ideje nőtt meg, hanem az életképes spórák száma is lecsökkent. A csendesített izolátumokat gyakran csak egy telepdarab friss táptalajra való helyezésével lehetett továbboltani. Amennyiben olyan telepdarabot oltottunk tovább, mely az aktívan növő teleprészből származott, a friss táptalajon ismét megjelentek különböző szektorok. A 10. átoltási ciklus után a gyengén növő és szektorokat mutató transzformánsok elvesztették ezt a jellegzetes fenotípust, de amennyiben ismét kevés spórát oltottunk ki friss táptalajra újból megjelent ez a tulajdonság. Feltehetőleg a gomba próbálta eliminálni a plazmidról átíródó asRNS-t. A világos színű szektorokban a karotin termelés nem volt jelentős és a gomba abban az irányba nem is nőtt tovább. Valószínüleg ezeket a területeket a gomba valamilyen védelmi mechanizmus útján lezárta.

Eredményeink arra engednek következtetni, hogy a gomba növekedésében és morfogenezisében is jelentős szerepet kap a $h m g R 3$ gén terméke. A $h m g R 3$ csendesítésének hatására nem csak a gomba növekedése lassult le, hanem a makro- és mikromorfológiája is jelentősen megváltozott. $F$. graminearum $\mathrm{HMG-KoA} \mathrm{reduktáz} \mathrm{gén} \mathrm{mutációjának} \mathrm{hatására} \mathrm{a}$ végálló hifák elágazásaink száma megnőtt (Seong és mtsi. 2006). Hasonló elágazás-számbeli különbséget találtunk a Mucor hmgR3 gén csendesítésének hatására is. Növényekben a HMG-KoA reduktáz központi szerepet játszik az embrióban a magfejlődés során (Stermer és mtsi. 1994). A magfejlődés korai szakaszában, amikor intenzív növekedés jellemző, szükséges az enzim jelenléte, hogy létrejöjjenek a különböző fontos izoprén származékok. Ezen kívül az enzim esszenciális a sejtdifferenciálódás és a sejtnövekedés folyamataiban is. Basson és munkatársai (1986) kimutatták S. cerevisiae-ben az enzim központi szerepét a sejtek vegetatív növekedésében. Az élesztő mind két reduktáz génjének egyidejű deletálása letális. A $h m g R 3$ gén terméke eredményeink alapján fontos szerepet játszik a gomba növekedéséhez és a sejtek differenciálódásához kulcsfontosságú izoprének bioszintézisében. A $h m g R l$ esetében nem csak a gén túlmüködtetése, de a csendesítése is plazmakiáramlásokat eredményezett, hasonlóan a $h m g R 2$ gén csendesítéséhez. E két gén termékének tehát szerepe lehet a citoplazmamembrán integritásának fenntartásában. 


\subsubsection{A transzformáns törzsek karotin és ergoszterin tartalmának vizsgálata}

A vizsgálathoz az egyes izolátumokat 4 napig állandó megvilágítás mellett tenyésztettük $25^{\circ} \mathrm{C}$-on. A telepeket csipesszel gyüjtöttük be a táptalaj felszínéről. A karotin kivonást friss, nedves micéliumból végeztük el, a karotinoidok mennyiségi meghatározásához spektrofotométert használtunk. Az ergoszterin kivonáshoz szárított micéliumot használtunk, majd HPLC analízissel mértük a termelödött mennyiséget. A kivonásokat 2-2 transzformáns izolátum felhasználásával végeztük és az eredményeket átlagoltuk. Az 5. táblázatban látható a különböző transzformánsok karotin, illetve ergoszterin tartalma az MS12-höz viszonyítva.

A $h m g R l$ gén túlmüködtetése és csendesítése nem befolyásolta jelentősen a gomba karotin, illetve ergoszterin tartalmát. Az táblázatban látható, hogy az MS12-nél mért karotin tartalmat nem haladta meg a transzformánsok karotin tartalma és ugyan ez igaz az ergoszterin tartalomra is, ahol a vizsgált törzsek ergoszterin tartalma a 6 mg/g körül mozgott.

5. táblázat. A hmgR1 gén túlmúködtetésének és csendesítésének hatása a gomba karotin és ergoszterin tartalmára.

\begin{tabular}{ccc}
\hline & $\begin{array}{c}\text { Karotin tartalom } \\
(\mu \mathrm{g} / \mathrm{g}[\mathrm{száraztömeg}] \pm \text { szórás })\end{array}$ & $\begin{array}{c}\text { Ergoszterin tartalom } \\
(\mathrm{mg} / \mathrm{g}[\mathrm{száraztömeg}] \pm \text { szórás })\end{array}$ \\
\hline MS12 & $476 \pm 65$ & $6,0 \pm 0,8$ \\
MS12-pNG1 & $460 \pm 68$ & $5,9 \pm 1,1$ \\
MS12-pAS1 & $487 \pm 41,4$ & $5,1 \pm 0,12$ \\
MS12-pNG2 & $741 \pm 86 * *$ & $7,4 \pm 0,8 *$ \\
MS12-pAS2 & $457 \pm 74,3 *$ & $4,4 \pm 0,01 *$ \\
MS12-pNG3 & $846 \pm 62 * *$ & $6,5 \pm 1,1$ \\
MS12-pAS3 & $193,2 \pm 48,4 * *$ & $3,8 \pm 0,16 * *$
\end{tabular}

A táblázatokban 3 egymástól független mérés eredményeinek átlagát \pm a szórás értékeit tüntettük fel. Az MS12 törzs esetében mért értekektől való szignifikáns eltérést * $(\mathrm{p}<0.05)$, illetve $* *(\mathrm{p}<0.01)$ jelzi. A szignifikancia szint mérésére párosítatlan t-próbát végeztünk.

A $h m g R 2$ gén túlmüködtetésének hatására a transzformáns törzsekben (MS12pNG2) szignifikánsan megnövekedett a karotin és az ergoszterin tartalom az MS12-nél mért értékhez képest. A gén csendesítésének hatására azonban a pAS2 vektort hordozó transzformánsok esetében nem változott a karotin tartalom, ellenben az ergoszterin szint 4,4 $\mathrm{mg} / \mathrm{g}$ értékre csökkent. 
A $h m g R 3$ gént túlmüködtetve szignifikánsan nött a pNG3-as vektort hordozó transzformánsok karotin tartalma, azonban az ergoszterin tartalmuk jelentősen nem változott. A csendesített transzformánsok esetében (MS12-pAS3), mind a karotin, mind az ergoszterin tartalmuk csaknem a felére csökkent.

Eredményeink azt mutatják, hogy a pNG1 és pAS1 vektort hordozó transzformánsok karotin és ergoszterin tartalma nem változott jelentősen az MS12-nél mért értékekhez képest, vagyis a $h m g R l$ müködése nem befolyásolja e két termék képződését a $M$. circinelloides esetében. A $h m g R 2$ és $h m g R 3$ müködése befolyásolja mind a karotin, mind az ergoszterin tartalmat, ugyanis e gének túlmüködtetésének és csendesítésének hatására, ugyan különböző mértékben, de megváltoztak a vad típusú törzshöz képest. A HMG-KoA reduktáz másodlagos metabolitok bioszintézisében betöltött szerepe régóta ismert és tanulmányozott a különbözö organizmusokban. H. volcanii archaea baktériumnál megfigyelték, hogy az optimálisnál magasabb sókoncentráció mellett tenyésztve a baktériumot, nőtt a HMG-KoA reduktáz aktivitás és ezzel párhuzamosan a sejtmembrán lipid és karotinoid tartalma is (Bidle és mtsi. 2007). Karotin termelö $C$. utilis-ben növelve a $h m g R l$ gén kópiaszámát sikerült túlmüködtetni a MEV útvonalat és fokozni a karotin produkciót. Hasonló eredményt értek el karotinoidot termelő $S$. cerevisiae-ben is (Verwaal és mtsi. 2007), ahol a HMG-KoA reduktáz kópiaszám-emelésének hatására nőtt a termelődött karotinoid mennyisége. Az eredményeink arra utalnak, hogy a $M$. circinelloides-ben zajló karotinoid bioszintézisben mind a $h m g R 2$, mind a $h m g R 3$ szerepet játszik.

\subsubsection{Apoptotikus folyamatok detektálása}

A $h m g R$ gének csendesítésének hatására, különösen a $h m g R 3$ esetében, az ergoszterin szint csökkent, a spórák csírázási ideje kitolódott, a gombatörzsek növekedése lelassult, megváltozott a telepek makromorfológiája és a fénymikroszkópos vizsgálatok során plazmakiáramlásokat és megduzzadt hifákat láthattunk. Mindezen változások fényében megvizsgáltuk, hogy nem játszódik-e le a transzformánsokban apoptózis jellegủ folyamat. A vizsgálathoz Annexin V-FITC festéket és propídium-jodidot alkalmaztunk. Az annexin V a plazmamembránon kifelé forduló foszfatidil-szerinhez képes kötődni és zöld fluoreszcens fénnyel az apoptózis korai fázisát detektálja, míg a propídium-jodid a sejtmagmembrán dezorganizációját követően a DNS-t köti és piros fluoreszcens fényt bocsájt ki, ezzel jelezve a nekrózist. A törzseket $25{ }^{\circ} \mathrm{C}$-on YNB tápoldatban neveltük. A festéshez a leoltástól számított 8 . órában vettünk mintákat. 


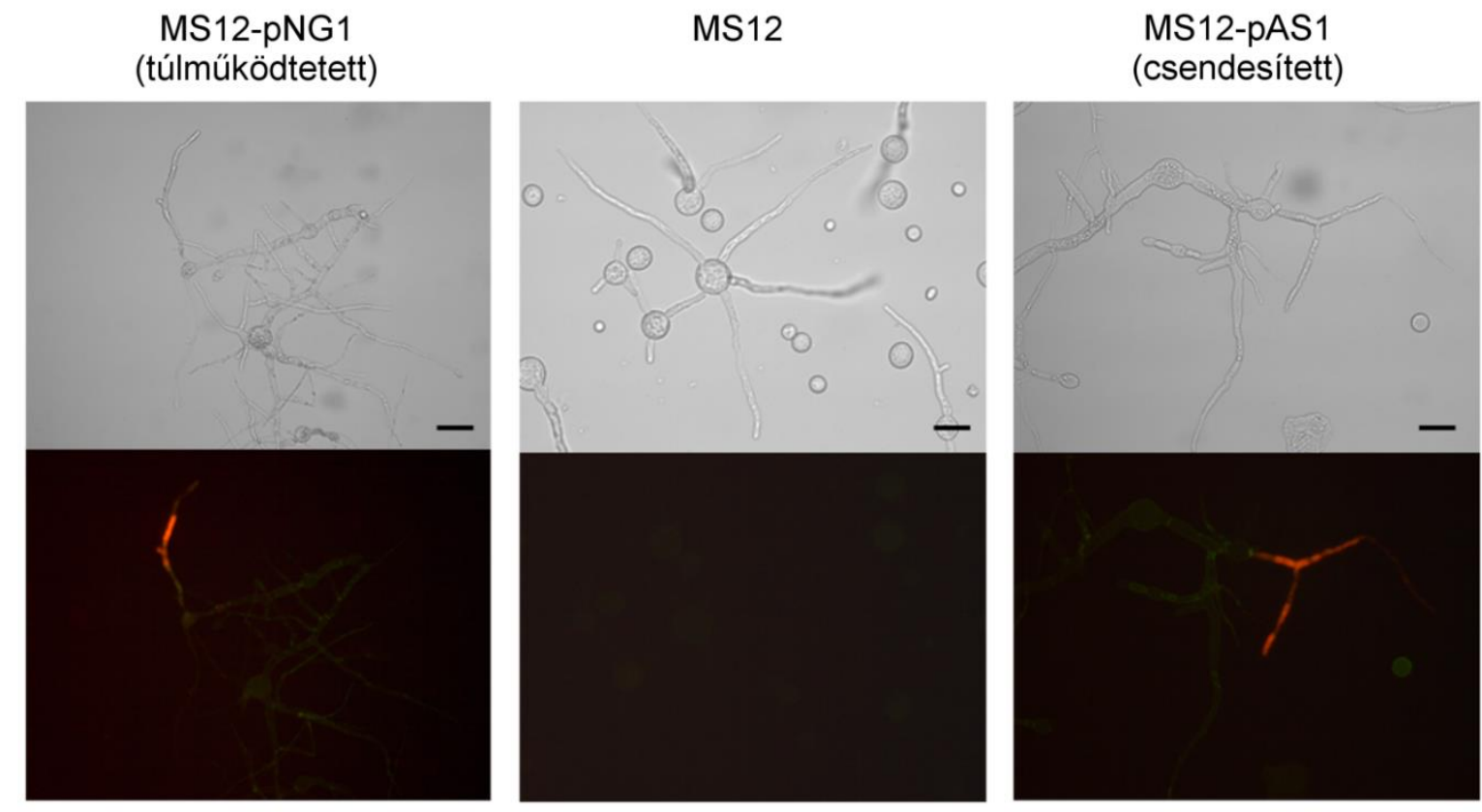

34. ábra. Az MS12, MS12-pNG1 és MS12-pAS1 izolátumok fénymikroszkópos és fluoreszcens. mikroszkópos képe az apoptózist detektáló festést követően. A méretskála $10 \mu \mathrm{m}$-nek felel meg.

A $h m g R 1$ géntúlmüködtetésének és csendesítésének hatására nem tapasztaltunk jelentősebb változást a gomba növekedésében, ergoszterin és karotin termelésében, azonban a makromorfológiai vizsgálatok során, mindkét esetben plazmakiáramlásokat fedeztünk fel. A festést követően mind a pNG1, mind a pAS1 vektort hordozó transzformánsok esetében találtunk propídium-jodid pozitív hifaszakaszokat, azonban annexin V pozitívokat nem (34. ábra). A plazmakiáramlások a citoplazmamembrán integritásának megváltozására, sérülésére utalnak, ami miatt a sejtekben beindulhatnak nekrotikus folyamatok és sejtpusztulás. Az MS12 esetében sem annexin V, sem propídium-jodid pozitív sejteket nem találtunk.

Megvizsgálva az MS12-pNG2 és MS12-pAS2 transzformánsokat azt tapasztaltuk, hogy a $h m g R 2$ gén túlmüködtetésének hatására nem következik be apoptotikus folyamat a sejtekben. Sem a korai apoptózist, sem nekrózist nem detektálunk ezekben az izolátumokban. A gén csendesítésének hatására kis mennyiségben ugyan, de elöfordultak nekrotikus (propídium-jodid pozitív) hifák (35. ábra). 


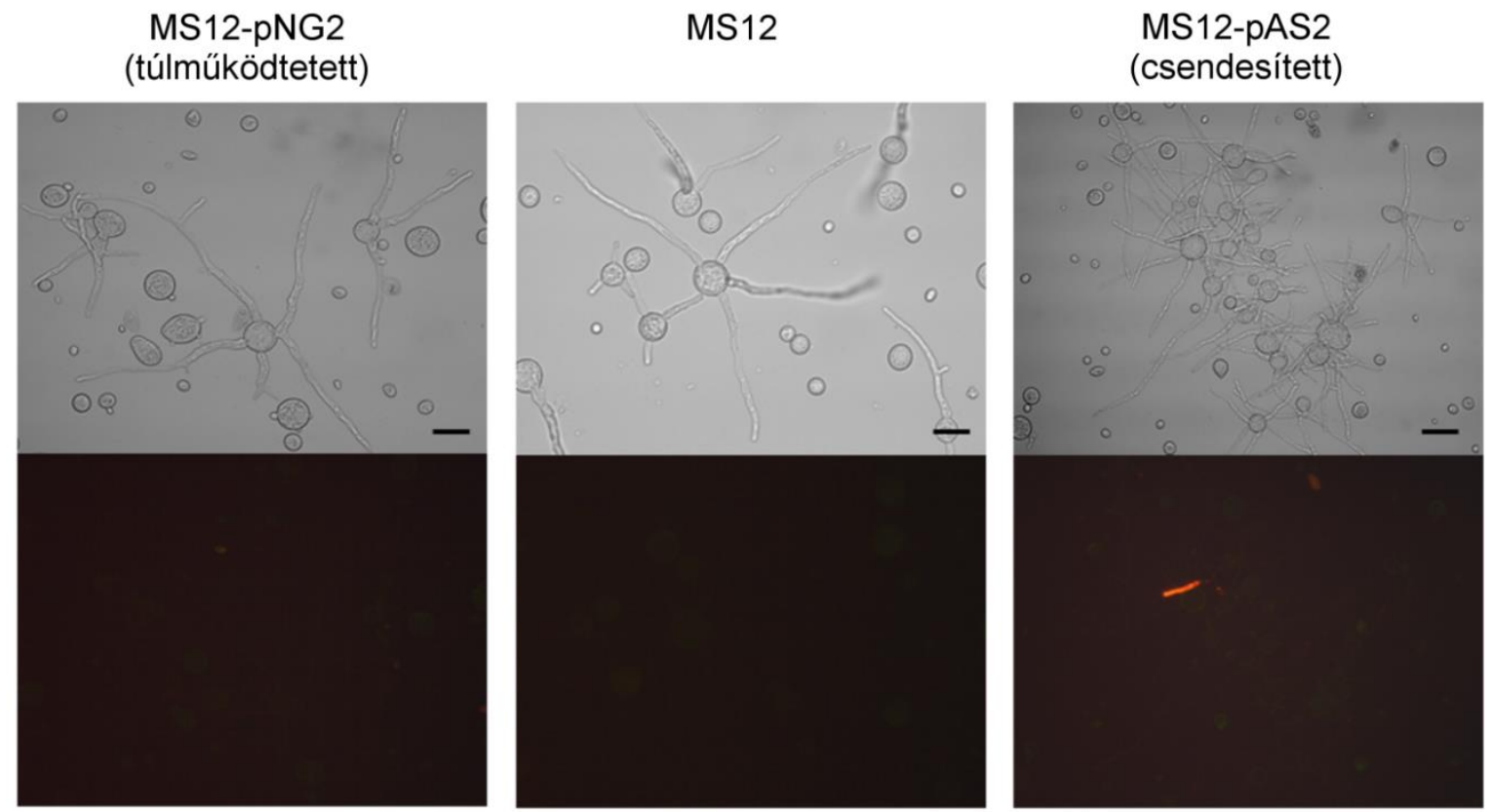

35. ábra. Az MS12, MS12-pNG2 és MS12-pAS2 izolátumok fénymikroszkópos és fluoreszcens mikroszkópos képe az apoptózist detektáló festést követően.

A méretskála $10 \mu \mathrm{m}$-nek felel meg.

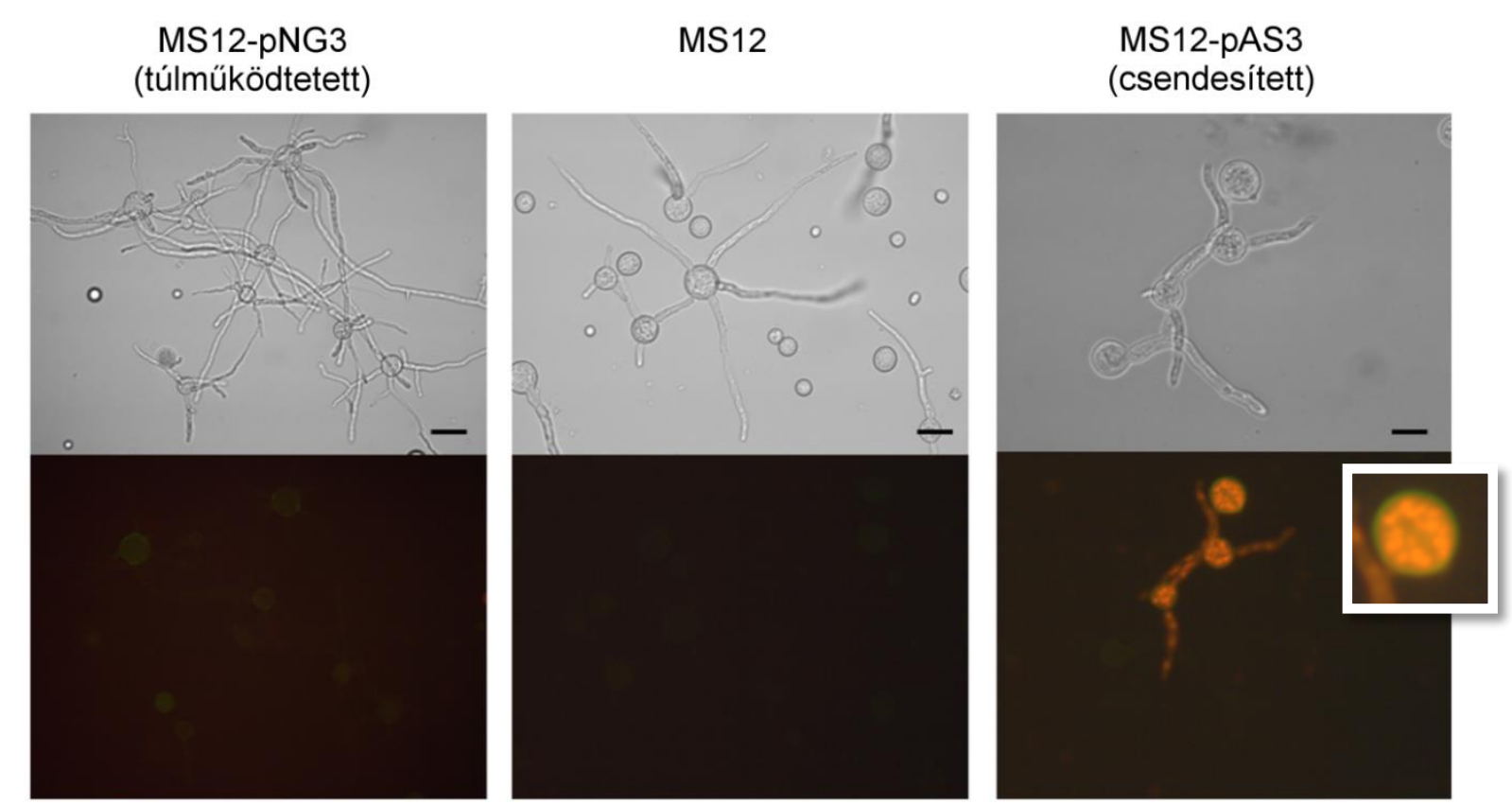

36. ábra. Az MS12, MS12-pNG3 és MS12-pAS3 izolátumok fénymikroszkópos és fluorescens mikroszkópos képe az apoptózist detektáló festést követően.

Fehér keretben kiemelve az annexin $\mathrm{V}$ pozitív sejt. A méretskála $10 \mu \mathrm{m}$-nek felel meg.

A $h m g R 2$ génhez hasonlóan a $h m g R 3$ gén túlmüködtetése során nem tudtunk detektálni korai vagy kései apoptózist, azonban a gén csendesítésének hatására, ahogy a 36. ábrán is látható megjelentek az annexin $\mathrm{V}$ - propidim-jodid pozitív sejtek és hifák. Ezeknél a mutánsoknál igen nagyszámban találtunk nekrotikus sejteket, mely fokozott sejtpusztulásra utaltak. 
Gombák esetében a RAS fehérjének mind pro-, mind anti-apoptotikus hatását kimutatták (Ramsdale 2006). A RAS fehérje a kis GTPázok családjába tartozik és részt vesz a sejtek proliferációjában, differenciációjában és az apoptotikus folyamatokban. A fehérje prenilációjának gátlása révén gombákban és humán rákos sejtvonalakban is apoptózis indukálódott. Különböző karcinóma sejtekben a HMG-KoA reduktáz gátlása ER stressz választ váltott ki, mely apoptózishoz vezetett (Joo és Jettem 2010). Mivel a HMG-KoA reduktáz az izoprén bioszintézis korai szakaszának központi lépését katalizálja, ezért a gén csendesítése és az enzim szelektív gátlása kihat a különböző izoprén termékek szintézisére, így az egyes fehérjék funkciós csoportját adó farnezil képzésére is. Emlős és gomba sejtekben a RAS fehérje prenilációjának indirekt gátlása révén csökkent a RAS fehérje termelődés. $M$. racemosus esetében a RAS fehérjék érésének gátlása révén csökkent a gomba növekedése és a sporangiospórák kialakulásának mértéke, mely változások a gombasejtekben apoptotikus folyamatokat indukáltak (Roze és Linz 1998). A fenti eredmények tekintetében feltehetö, hogy a $h m g R 3$ részt vesz ezen vagy más fehérjék prenil csoportjainak kialakulásában és így müködésének gátlása apoptotikus folyamatokat indukálhat.

$M$. circinelloides esetében a $h m g R l$ gén túlmüködtetésének és csendesítésének hatására nekrotikus hifaszakaszokat azonosítottunk, mely változás azt mutatja, hogy ezekben a sejtekben a sejtmagmembrán dezorganizálódott és az adott hifaszakasz elhalt. A hmgR2 túlmüködtetése nem, de a gén csendesítése hatására szintén nekrotikus hifaszakaszokat tudtunk detektálni. A két gén esetében a mutánsokban azonban nem tudtuk kimutatni a korai apoptózist. A hmgR3 gén túlmüködtetésének hatására sem indukálódott apoptózis a mutánsokban, azonban a gén csendesítésének hatására az apoptózis korai és kései fázisát is detektálni tudtuk. A plazmakiáramlások, a gombatelep szektorozottsága, az ergoszterin tartalom csökkenése és a korai apoptózis, valamint a nekrózis detektálása arra engednek következtetni, hogy a HmgR3 szerepet játszhat a sejtek proliferációjában és az apoptotikus folyamatokban.

\subsubsection{A mutáns törzsek sztatinokkal szembeni érzékenységének vizsgálata}

A sztatin érzékenység vizsgálatot 96 lyukú mikrotiter lemezen végeztük, melyet 25 ${ }^{\circ} \mathrm{C}$-on inkubáltunk 3 napon keresztül. A vizsgálathoz atorvasztatint, rozuvasztatint és fluvasztatint használtunk. A 6. táblázatban a 48. órában mért OD értékekből számolt MIC90 értékek láthatóak. A kísérlet során transzformációnként 2-2 transzformáns telepet vizsgáltuk, 3 párhuzamosban. 
6. táblázat. A transzformáns törzsek és az MS12 sztatinokkal szembeni minimális gátlókoncentrációja (MIC90).

\begin{tabular}{cccc}
\hline & fluvasztatin $(\mu \mathrm{g} / \mathrm{ml})$ & atorvasztatin $(\mu \mathrm{g} / \mathrm{ml})$ & rozuvasztatin $(\mu \mathrm{g} / \mathrm{ml})$ \\
\hline MS12 & 4 & 16 & 32 \\
MS12-pNG1 & 4 & 16 & 32 \\
MS12-pAS1 & 4 & 16 & 32 \\
MS12-pNG2 & 32 & & $>256$ \\
MS12-pAS2 & 4 & 16 & 32 \\
MS12-pNG3 & 64 & & $>256$ \\
MS12-pAS3 & 4 & 16 & 32 \\
\hline
\end{tabular}

A táblázatokban 3 egymástól független mérés eredményeinek átlagát tüntettük fel.

A fluvasztatin $\mathrm{MIC}_{90}$ értéke MS12 esetében 4, az atorvasztatiné 16, míg rozuvasztatiné $32 \mu \mathrm{g} / \mathrm{ml}$ értéknek bizonyult. Az eredményekből látszik, hogy a három sztatin közül a fluvasztatin gátolta legjobban az izolátumokat, míg a rozuvasztatin a legkevésbé. A hmgRl gén csendesítésének vagy kópiaszámának emelése nem befolyásolta a transzformáns törzsek sztatinokkal szembeni érzékenységét (6. táblázat).

A $h m g R 2$ gén csendesítésének hatására nem változott a transzformáns törzsek sztatinokkal szembeni érzékenységük a vad típusú törzshöz képest (6. táblázat). A gén kópiaszámának emelésére az MS12-pNG2 mutánsok sztatinokkal szembeni érzékenysége csökkent. Fluvasztatin esetében $4 \mu \mathrm{g} / \mathrm{ml}$-röl $32 \mu \mathrm{g} / \mathrm{ml}-\mathrm{re}$, atorvasztatin esetében $16 \mu \mathrm{g} / \mathrm{ml}$ ról $256 \mu \mathrm{g} / \mathrm{ml}-\mathrm{re}$, míg rozuvasztatin esetében $32 \mu \mathrm{g} / \mathrm{ml}$-ról több, mind $256 \mu \mathrm{g} / \mathrm{ml}-\mathrm{re}$ emelkedett a sztatin koncentráció, mely gátolta a gomba növekedését.

A $h m g R 3$ gén esetében hasonló eredményeket kaptunk, mint a hmgR2-nél. A gén csendesítésének hatására nem változott a transzformáns izolátumok sztatinokkal szembeni érzékenysége, míg a gén túlmüködtetésének hatására a mutánsok sztatinokkal szembeni érzékenysége csökkent. Ez az érzékenység csökkenés azonban jelentősebb volt, mint az előző gén esetében. A 6. táblázatban látható, hogy az MS12-pNG3 transzformánsok MIC 90 értéke a fluvasztatin esetében $4 \mu \mathrm{g} / \mathrm{ml}$-ről $64 \mu \mathrm{g} / \mathrm{ml}$-re, atorvasztatin és rozuvasztatin esetében pedig, 16 illetve $32 \mu \mathrm{g} / \mathrm{ml}$-röl több mint $256 \mu \mathrm{g} / \mathrm{ml}$-re változott.

A Trichoderma harzianum hmgR génjének csendesítése során (Cardoza és mtsi. 2006) a gomba érzékenyebbé vált a lovasztatinnal szemben, valamint kevesebb ergoszterin 
termelésére volt képes (Cardoza és mtsi. 2007). A M. circinelloides hmgR génjeinek csendesítése során a transzformáns törzsek sztatin érzékenysége ugyan nem változott, azonban a $h m g R 2$ és $h m g R 3$ csendesített mutánsok karotinoid és ergoszterin tartalma jelentősen lecsökkent (6.4.5. fejezet).

Az jól ismert, hogy a sztatinok a HMG-KoA reduktáz szelektív gátlószerei, melyeket a humán gyógyászatban koleszterinszint csökkentő gyógyszerként alkalmaznak, azonban humán patogén gombákkal szembeni antifungális hatásuk igen intenzíven kutatott terület (Chamilos és mtsi. 2006 ; Qiao és mtsi. 2007; Galgóczy és mtsi. 2009, 2010). A HMG-KoA reduktáz gátlása révén $M$. racemosus-ban apoptózis-szerü folyamatok indukálódtak lovasztatin kezelés hatására. Lukács és munkatársai (2009) klónozták a R. miehei HMGKoA reduktázát, melyet $M$. circinelloides-ben expresszáltattak. Az így kapott transzformánsok sztatinokkal szembeni érzékenysége ugyan lecsökkent, azonban a törzsek karotinoid tartalma nem változott. $M$. circinelloides esetében, mi azt az eredményt kaptuk, hogy mind a $h m g R 2$, mind a $h m g R 3$ túlmüködtetésének hatására nőtt a transzformánsok karotin tartalma és csökkent a sztatinokkal szembeni érzékenységük, azonban $h m g R l$ esetében ilyen változást nem tapasztaltunk.

Sch. pombe és Ustilago maydis HMG-KoA reduktázának katalitikus régiója nagyfokú hasonlóságot mutat a humán HMG-KoA reduktáz katalitikus régójával, így kiváló modell új antifungális szerek teszteléséhez (Andrade-Pavón és mtsi. 2013). A $h m g R 2$ és hmgR3 gén túlmüködtetésének hatására a gomba sztatinokkal szembeni érzékenysége jelentősen csökkent, ami azt jelzi, hogy ugyancsak kiváló terápiás célpontok lehetnek, új gombaellenes szerek kifejlesztése során.

\subsubsection{A $h m g R$ gének funkcionális vizsgálatának legfontosabb eredményei}

A gének túlműködtetésével és csendesítésével kapott eredményeket a következőképpen foglalhatjuk össze: a $h m g R l$ gén túlmüködtetésének és csendesítésének hatására nem tapasztaltunk jelentős változásokat. A transzformánsok esetében mind két esetben plazmakiáramlásokat és nekrotikus hifákat találtunk, mely azt sugallja, hogy a hmgRl megváltozott müködése kihatással van a plazmamembrán integritására. A hmgR2 gén overexpressziója hatással volt a gomba karotin és ergoszterin tartalmára, míg a gén csendesítése plazmakiáramlásokat, nekrotikus hifákat és ergoszterin tartalom csökkenést eredményezett. Eredményeink arra utalnak, hogy a HmgR2 az általános izoprén bioszintézis útvonalban vehet részt. A $h m g R 3$ kópiaszámának emelése a gomba karotin tartalmát jelentősen megnövelte, míg a sztatinokkal szembeni érzékenység jelentősen lecsökkent. A 
gén csendesítésének hatására a transzformáns telepek növekedése lelassult, a telep morfológiája megváltozott és a hifák szabálytalanná váltak, amihez plazmakiáramlások is társultak. Ezekben a transzformánsokban apoptózisszerü folyamatokat is sikerült detektálni. Feltehetőleg a HmgR3 a HmgR2-vel átfedve felelős a karotin és ergoszterin bioszintézisért. Emellett az elöbbinek specifikus szerepe van a gomba morfogenezis és növekedés során, valamint az apoptotikus folyamatokban.

\subsection{A HMG-KoA reduktázok sejten belüli lokalizációjának vizsgálata}

Az egyes HmgR fehérjék funkciójának jobb megismerése céljából szükséges a fehérjék sejten belüli lokalizációjának meghatározása. A S. cerevisae Hmg1p fehérje az ER sejtmag felöli részén helyezkedik el (Koning és mtsi. 1996) és részt vesz az ER membrán proliferációjában (Basson és mtsi. 1988), ezzel szemben a Hmg2p az ER membrán perifériáján, a citoplazma felöli oldalon lokalizálódik, és fontos szerepe van az oxigénérzékelésben. Saccharomyces Hmg1p-t túlmüködtetve beindul az ER sejtmag felöli membránrendszerének az úgynevezett karmelle-nek a proliferációja. Emlös sejtekben a HMG-KoA reduktáz gátlása révén az ER-ben stresszválasz indukálódik, mely apoptózishoz vezet (Joo és Jetten 2010). A Mucor reduktázok sejten belüli lokalizációjának vizsgálata arra is választ adhat, vajon a különböző izoprénvázas vegyületek egymástól független, külön kompartmentben szintetizálódnak-e a sejten belül. P. blakesleeanus-ban és B. trispora-ban megfigyelték a különböző izoprén származékok szintézisének kompartmentalizációját (Bejarano és mtsi. 1992; Kuzina és mtsi. 2006). Az ubikiinon és ergoszterin azonos, míg a karotinoidok külön kompartmentben szintetizálódnak, már az acetil-koenzim A-tól kezdődően (Bejarano és mtsi. 1992; Kuzina és mtsi. 2006). Emlösökben HMG-KoA reduktáz az ER-ben és a peroxiszómában lokalizálódik, azonban a szterinek és az ubikiinon szintézise itt is elkülönül (Breitling és mtsi. 2002).

A HMG-KoA reduktázok sejten belüli lokalizációjának vizsgálatához a reduktázokat zöld fluoreszcens fehérjével (GFP) fuzionáltattuk. A zöld fluoreszcens fehérjét 1961-ben fedezték fel (Shimomura 1962) és azóta is a különbözö biológiai folyamatok vizsgálatának egyik fontos eszköze. Más riporter fehérjékkel ellentétben nagy előnye, hogy nem igényel további szubsztrátot a fehérje az in situ megfigyelésekhez. A GFP egy 286 aminosavat tartalmazó 26,9 kDa tömegủ fehérje, melyet kék (545 nm) vagy UV fénnyel (395 nm) gerjesztve zöld $(508 \mathrm{~nm})$ fluoreszcens fényt bocsájt ki (Tsien 1998). Járomspórás gombákban eddig csak két fajban használták a gfp-t, mint riporter gént. A. glauca-ban a $g f p$ t génexpressziós vizsgálatban alkalmazták (Schilde és mtsi. 2001). Autonóm replikatív 
plazmidot alkalmazva, azt tapasztalták, hogy különböző szektorok alakultak ki a transzformálás után, melyek hordozták vagy elvesztették a bejuttatott plazmidot. Backusella lamprospora-ban az Agrobacterium tumefaciens közvetített transzformáció sikerességének nyomon követésére alkalmazták a GFP-t (Nyilasi és mtsi. 2008).

A fúziós fehérjék összeépítéséhez a már említett pNG1, pNG2 és pNG3 vektorokat (21. ábra) használtuk fel. Ezen vektorokon kívül rendelkezésünkre állt a laborunkban korábban létrehozott pPT43-gfp vektor is, mely a $g f p$ gént a Mucor $g p d \mathrm{P}$ és $g p d \mathrm{~T}$ szakaszok között hordozta. A pNG vektorokban található $h m g R$ géneket a $h m g R l$ esetében NheI-NotI, míg a $h m g R 2$ és $h m g R 3$ gén esetében EcoRI-NotI endonukleázokkal emésztettük, ezáltal csonkoltuk a gének azon szakaszát, mely a fehérje katalitikus aktivitásért felelős régióját kódolja (37. ábra).
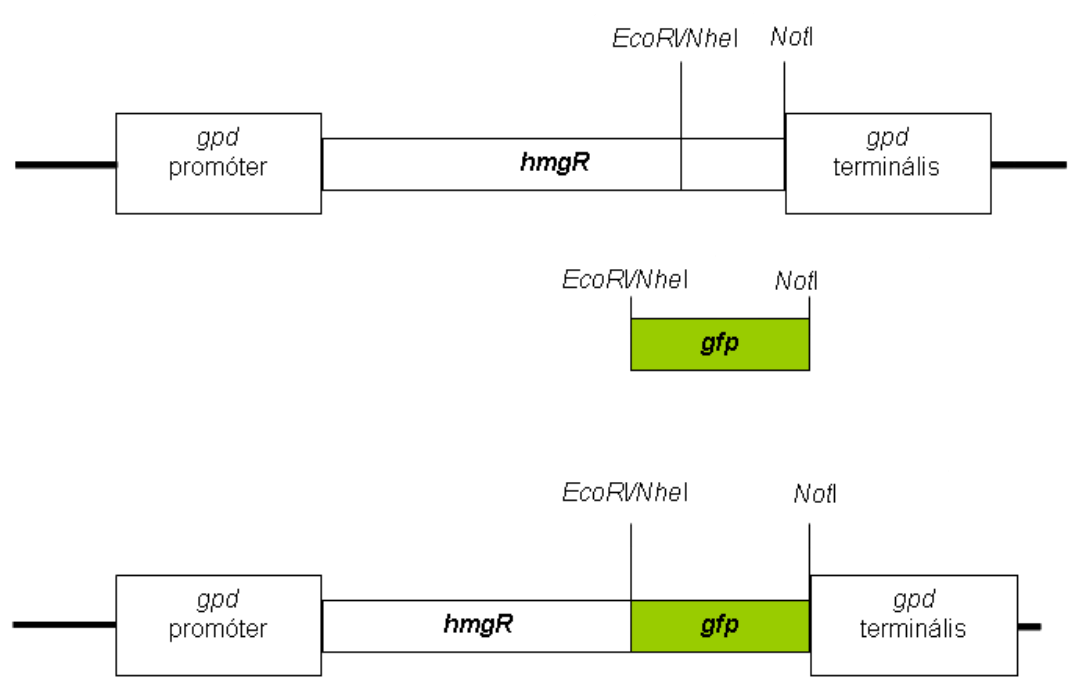

37. ábra. A HmgR fehérjék sejten belüli lokalizációjának vizsgálatára alkalmas vektorok építésének folyamatábrája.

Az endonukleázokkal történt emésztés után a $g f p$-t ligálás útján összeépítettük a reduktáz gének azon szakaszával, mely a fehérjék transzmembrán régióját kódolja, lecserélve a katalitikus régiót kódoló génszakaszt. Az összeépítés során ügyeltünk a leolvasási keret sértetlenségére. A fúzióhoz használt aminosav szakaszok a következők voltak; HmgR1 esetében 1-553 as, a HmgR2 esetében 1-756 as, míg a HmgR3 esetében 1825 as. Ezzel a módszerrel létrehoztuk a pH1cGFP, pH2cGFP és a pH3cGFP vektorokat (38. ábra). A $g f p$-t minden esetben szekvenálással ellenőriztük. 

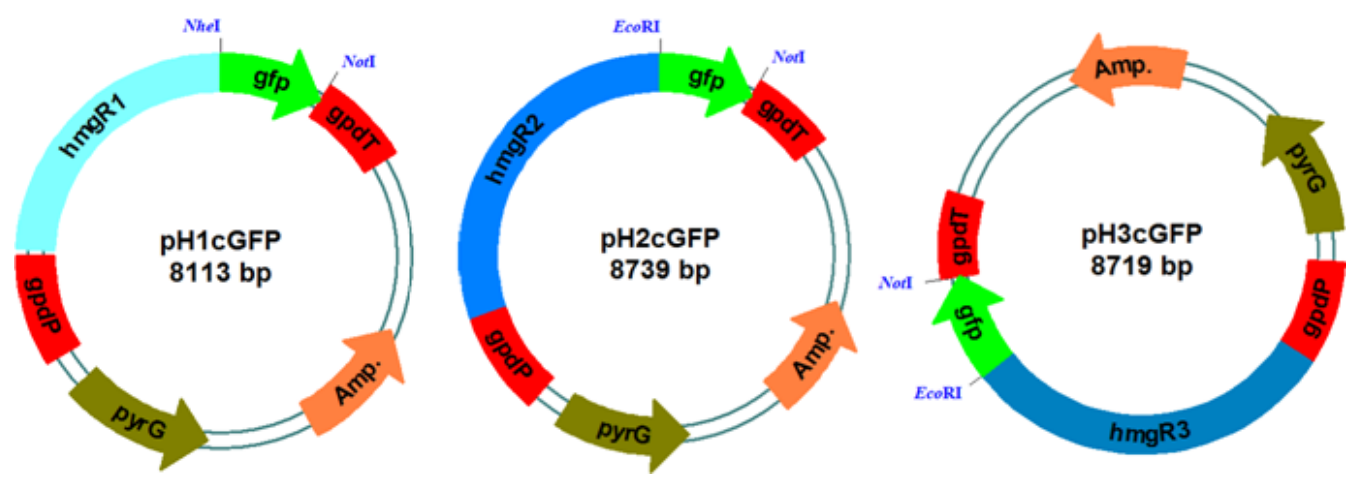

38. ábra. A HmgR fehérjék lokalizációjának vizsgálatához épített vektorkonstrukciók.

A fehérjék transzmembrán régiója nem sérült meg, így a sejten belül az egyes reduktáz fehérjének megfelelő membránrendszerbe tudnak beépülni, a GFP-vel pedig a fehérje lokalizációja sikeresen nyomon követhető. A vektorokkal sikeres PEG-mediált protoplaszt transzformációt hajtottunk végre, majd a transzformálást követően 10-10 transzformáns telepet izoláltunk. A transzformánsok a plazmidokat autonóm replikatív elemként tartják fenn. Az izolátumok közül transzformációnként kiválasztottunk 1-1 transzformáns telepet (MS12-pH1cGFP-1, MS12-pH2cGFP-1 és MS12-pH3cGFP-1) és megkezdtük azok vizsgálatát. Fluoreszcens mikroszkóp felhasználásával, valamint DNS és RNS izolálást követően PCR-rel is igazoltuk a $g f p$ jelenlétét a transzformánsokban és megkezdtük azok elemzését.

\subsubsection{A vektor konstrukciókat hordozó transzformánsok vizsgálata}

A transzformánsok ellenőrzését fluoreszcens mikroszkóppal is elvégeztük, azonban a GFP-t expresszáló hifák aránya alacsonynak bizonyult, ezért a plazmidokat hordozó spórák számának dúsítása érdekében monosporangiális telepeket képeztünk szelektív körülmények mellett. A vektorok gpd promótert tartalmaztak, amely glükózzal indukálható, így a fúziós fehérje kifejeződésének elősegítése érdekében 3\%-ra növeltük a tápoldat glükóz tartalmát. Ebben a 3\% glükózt tartalmazó tápoldatban rázattuk a telepeket 4 napon keresztül és folyamatosan figyeltük a GFP pozitív sejtek megjelenését. A leoltástól számított 2. napon volt a legmagasabb a GFP-t expresszáló sejtek aránya.

\section{$\underline{\text { MS12-pH1cGFP-1 }}$}

Az MS12-pH1cGFP-1 izolátum esetében a dúsítást követően is igen kis számban jelentek meg a GFP-t expresszáló sejtek. A glükózzal történő indukciót követően ezen sejtek aránya nem nőtt, azonban a 39. ábrán látható, hogy a GFP a sejten belül egy nagy kiterjedésü organellumban van jelen. 


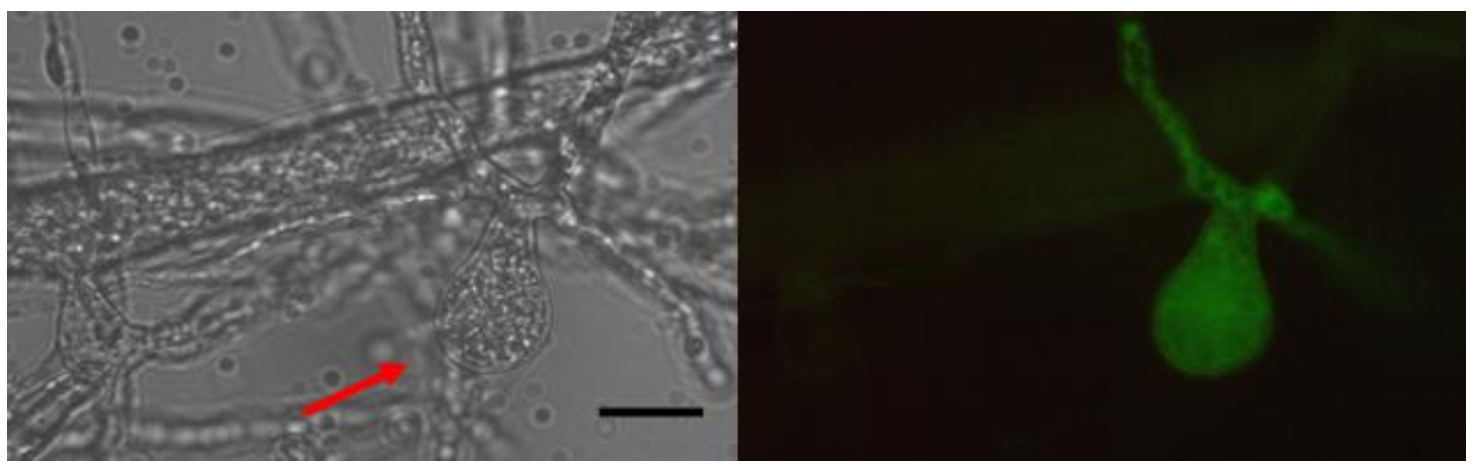

39. ábra. Az MS12-pH1cGFP-1 izolátum fény és fluoreszcens mikroszkópos felvétele.

Piros nyíl jelöli a GFP pozitív sejtet. A méretskála $10 \mu \mathrm{m}$-nek felel meg.

Megvizsgálva az izolátumot konfokális mikroszkóppal is (40. ábra), hasonló megállapításra jutottunk, miszerint a GFP jelölt fehérje egy nagy kiterjedésű organellumban van jelen. Mind két ábrán látható, hogy nem mindegyik sejtben fejeződik ki a GFP, annak ellenére, hogy szelektív körülmények között történt a mintaelőkészítés.

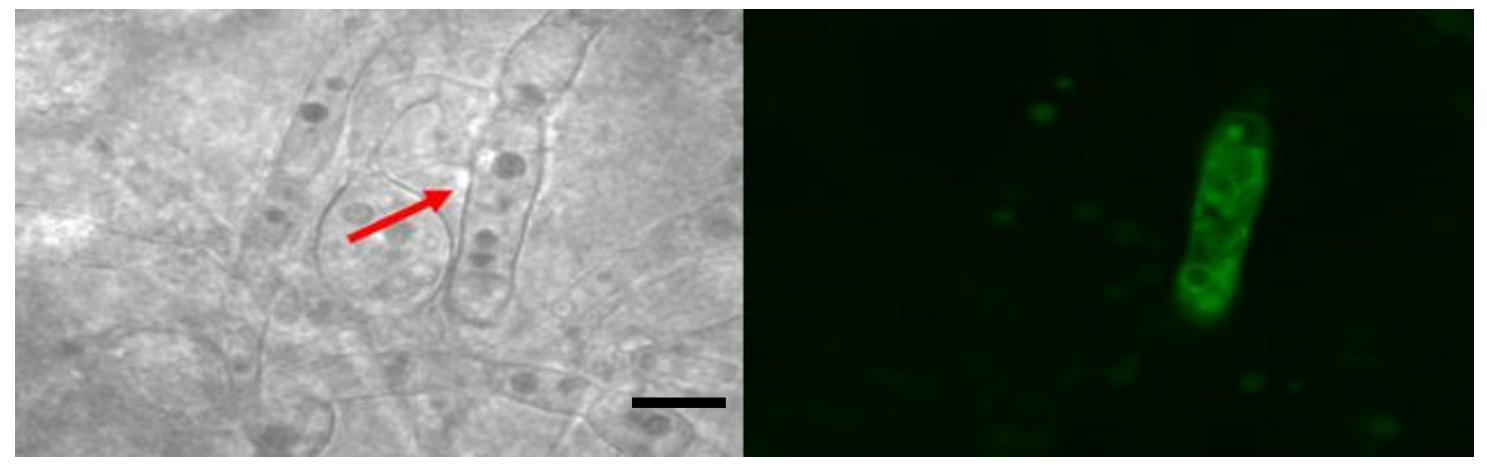

40. ábra. Az MS12-pH1cGFP-1 izolátum konfokális mikroszkópos felvétele. A piros nyíl mutatja a GFP-t hordozó sejtet. A méretskála $20 \mu \mathrm{m}$-nek felel meg.

A vizsgálataink során az MS12-pH1cGFP vektort hordozó transzformánsok esetében GFP jelet csak spórákban és csíratömlőben tudtunk detektálni, kifejlett hifákban viszont nem. A sejten belül a GFP nagy kiterjedése arra enged következtetni, hogy egy összefüggő membránrendszerben lokalizálódik a HmgR1, mely valószínüleg az ER.

\section{$\underline{\text { MS12-pH2cGFP-1 }}$}

Az MS12-pH2cGFP-1 izolátum esetében fluoreszcens mikroszkóp segítségével a sejten belül nagyobb és kisebb méretü régiókat tudtunk azonosítani, melyekben felhalmozódik a HmgR2':GFP fehérje (41. ábra). 


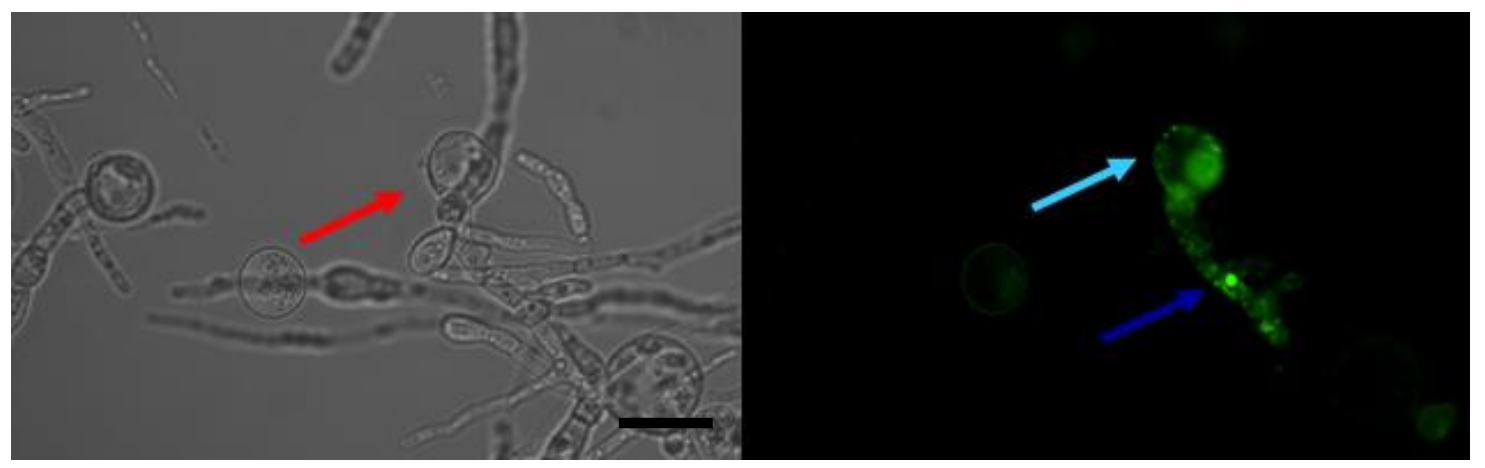

41. ábra. Az MS12-pH2cGFP-1 izolátum konfokális mikroszkópos felvétele.

A piros nyíl mutatja a GFP-t hordozó sejtet, a sötétkék nyíl a nagyméretü, míg a világoskék a kisméretü sejtorganellumot mutatja. A méretskála $20 \mu \mathrm{m}$-nek felel meg.

\section{$\underline{\text { MS12-pH3cGFP-1 }}$}

Az MS12-pH3cGFP mutánsok esetében szintén találtunk olyan hifákat, melyekben kifejeződik a HmgR3':GFP fehérje. A 42. ábrán látható, hogy a sejten belül a GFP nagyméretü régióban jelent meg, ellentétben a HmgR2':GFP fehérjével. Ahogy azt korábban írtam, ezeknél a mutánsoknál sem tudtuk elérni azt, hogy minden hifában kifejeződjön a GFP-vel fuzionáltatott fehérje, azonban a további vizsgálatokhoz a dúsítás elegendőnek bizonyult.

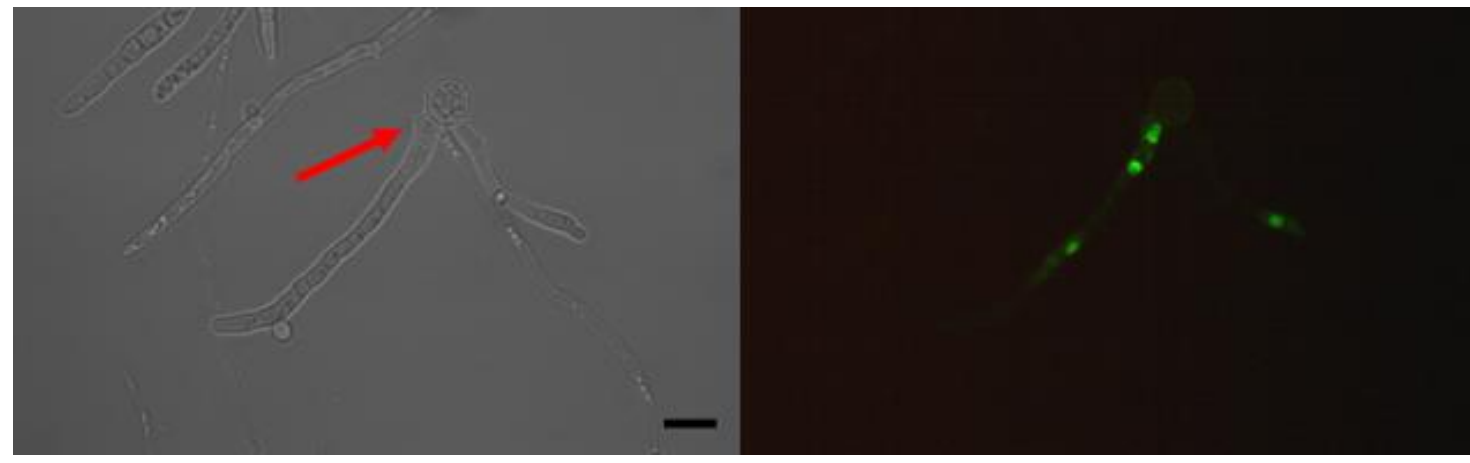

42. ábra. Az MS12-pH3cGFP-1 izolátum konfokális mikroszkópos felvétele. A piros nyíl mutatja a GFP-t hordozó sejtet. A méretskála 20 mm-nek felel meg.

Annak érdekében, hogy indukáljuk a gpd promótert és a mikroszkópos vizsgálatokhoz szükséges mértékben kifejeztethessük a GFP-fúziós fehérjéket, megemeltük a táptalaj glükóz tartalmát. Ennek következtében azonban, legalábbis elvileg, nagy mennyiségben termelődhetnek a GFP fúziós fehérjék a bejuttatott plazmidokról. Ezért annak a kiderítésére, hogy a megtermelödött fehérje nem az ER lumenjében halmozódik fel, illetve nem degradálódik, hanem a sejten belül akár az ER, akár valamely más organellum membránjába ágyazódik, ultracentrifugálással membránfrakciót izoláltunk. A membránfrakció mikroszkópos vizsgálata igazolta a GFP jelenlétét membránban. Emellett fluoriméteres analízissel megállapítottuk, hogy a pH2cGFP és pH3cGFP mutánsok esetében 
a tisztított membránfrakció fluoreszcenciája a kontroll törzsböl tisztított mintához képest 66 és $87 \%$-os emelkedést mutatott, míg a szolubilis frakcióból egyik esetben sem sikerült fluoreszcenciát kimutatnunk.

\subsubsection{Kolokalizációs vizsgálatok az endoplazmatikus retikulummal és mitokondriummal}

Fluoreszcens mikroszkóppal megvizsgálva az egyes mutáns törzseket, azt feltételeztük, hogy a nagy kiterjedésü GFP jelet mutató organellum valószínüleg ER, ugyanis a HMG-KoA reduktázok föként az ER membránjához horgonyzódnak (Liscum és mtsi. 1985; Basson és mtsi. 1986; Learned és mtsi. 1989; Friesen és Rodwell 2004; Lombard és Moreia 2011). Ennek a kiderítéséhez ER festést végeztünk ER-Tracker Red fluoreszcens festék felhasználásával, amely képes az élő sejtet festeni. A festék rendkívül érzékeny, mivel a benne található glibenklamid az ER specifikus ATP-szenzitív kálium csatornák szulfonurea receptoraihoz képes kapcsolódni (Hambrock és mtsi. 2002). A vizsgálatok során az is kiderült, hogy a HmgR2':GFP a sejten belül egy kisebb méretü, fluoreszcens mikroszkóppal pontszerünek látszó kompartmentben is felhalmozódik. H. werneckii esetében a HMG-KoA reduktáz az ER-en kívül a mitokondriumban is előfordulhat (Vaupotič és mtsi. 2007), ezért célszerünek gondoltuk a mitokondriumok festésének elvégzését is. A mitokondriumok festését MitoTracker Red FM fluoreszcens festék használatával végeztük. Ez a festék is képes az élő sejtekbe bejutni és nem szükséges a minták fixálása sem. A MitoTracker Red FM képes a sejthártyán passzívan átjutni a membránpotenciáltól függően. A mitokondriumba jutva, az ott lejátszódó oxidációs folyamatok során a festékben található tiol-reaktív molekulacsoportnak köszönhetően az eredetileg fluoreszcens tulajdonsággal nem rendelkező festék fluoreszcenssé válik (Poot és mtsi. 1996). Annak ellenére, hogy mind két festék képes az élő sejteket festeni, a Mucor esetében ez nem volt teljesen igaz. A festési eljárás optimalizálása során többféle inkubációt kipróbálva sikerült elérnünk, hogy a minták közel 50\%-a megfestődjön. A festés során a mintákat PBS oldattal mostuk, majd 30 percen keresztül $37^{\circ} \mathrm{C}$-on sötétben inkubáltuk. A munkát megnehezíti, hogy a Mucor sejtfalán nehezen jutnak át a különböző festékek, valamint hogy a GFP-fúziós fehérjét a sejtek viszonylag kis százaléka expresszálta.

Az MS12-pH2cGFP és MS12-pH3cGFP mutánsok esetében azonban a dúsításnak köszönhetően a sejtek relatíve nagy százalékában kifejeződött a GFP, így el tudtuk végezni ezekkel a mintákkal a festéseket. A festést követően a jobb felbontás eredménye érdekében konfokális mikroszkópot alkalmaztunk a vizsgálatokhoz. Az MS12-pH1cGFP mutáns 
esetében azonban még mindig kevés a GFP-t expresszáló sejtek aránya a mitokondrium és ER festéshez.

\section{$\underline{\text { MS12-pH2cGFP-1 }}$}

A 43. ábrán az MS12-pH2cGFP-1 transzformáns konfokális mikroszkóppal készített felvételei láthatóak az ER-Tracker Red festést követően.

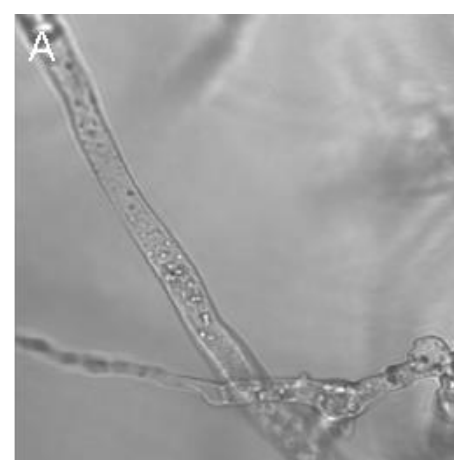

C

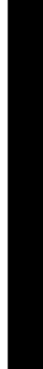

B

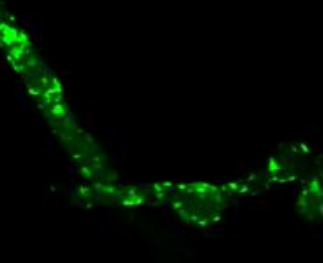

D

$E$

43. ábra. Az MS12-pH2cGFP transzformáns ER-Tracker Red festést követő konfokális mikroszkóppal készített felvételei.

A: fénymikroszkópos kép, B: GFP, C: Er-Tracker Red festés, D: A GFP és az ER-Tracker Red festéssel készült kép egymásra helyezve, E: nagyított kép a pontszerü GFP-k lokalizációjáról. A sárga nyíl jelöli a kolokalizációt, míg a fehér nyíl jelöli a kisméretü GFP jeleket, melyek nem mutatnak kolokalizációt az ERrel.

Fluoreszcens mikroszkóppal megvizsgálva az izolátumot azt tapasztaltuk, hogy a HmgR2':GFP fehérje a sejten belül két különböző méretű organellumban halmozódik fel (41. ábra). Ugyanezt a fajta felhalmozódást tapasztaltuk itt is. A 43B ábrán láthatunk nagyobb, összefüggő GFP jelet és kisebb, pontszerü GFP jelet is. A 43C képen a megfestett ER látható és amennyiben, ha erre rávetítjük a GFP-s képet (43D kép), akkor sárga színnel láthatóvá válik a kolokalizáció (sárga nyíl). Az Er-Tracker Red festést követően láthatóvá válik a kolokalizáció a HmgR2':GFP fehérje és az ER- között viszont, ahogy a 43E ábrán látható, a kis pontszerü régiók jól elkülönülnek az ER-től, nem mutatva azzal kolokalizációt. A 42D képen fehér nyíllal jelölt rész felnagyított ábrája látható, ahol jobban kivehetőek azok a kis pontszerü organellumok, melyek nem mutatnak kolokalizációt az ER-rel. 


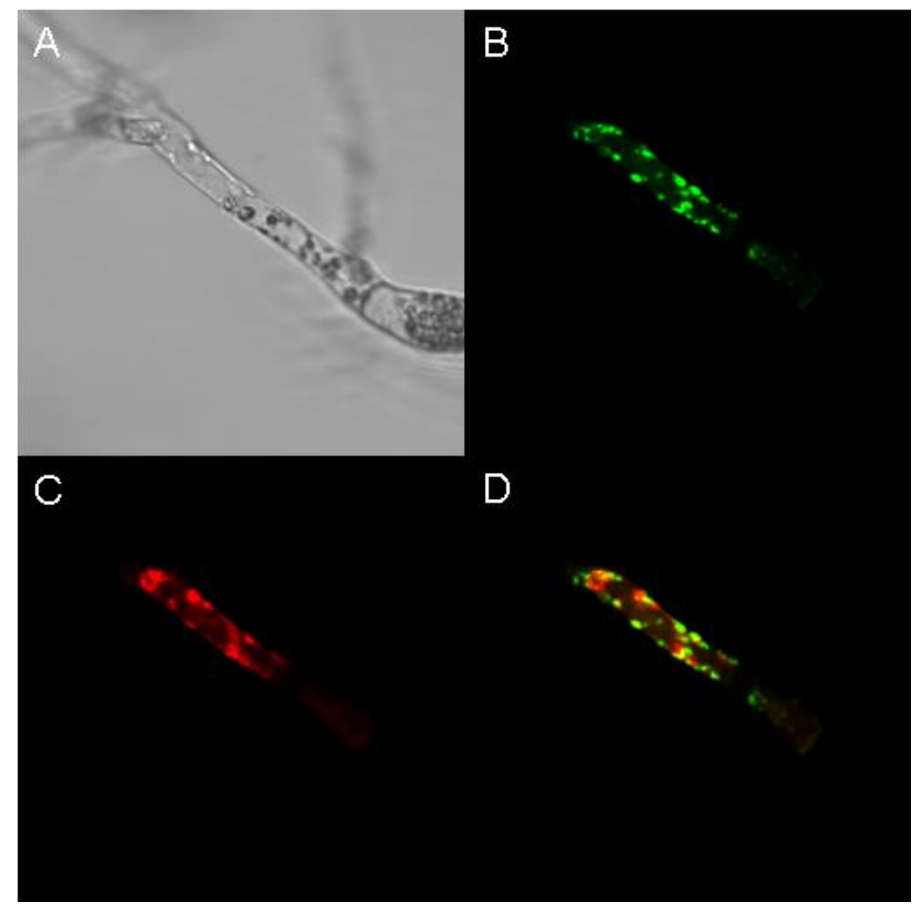

44. ábra. Az MS12-pH2cGFP transzformáns konfokális mikroszkóppal készített felvételei. A: konfokális mikroszkópos kép, B: GFP, C: MitoTracker Red festés, D: A GFP és a MitoTracker Red festéssel készült kép egymásra helyezve.

A 44. ábrán ugyanennek az izolátumnak a MitoTracker Red festését követő konfokális mikroszkópos felvétele látható. A 44B képen a GFP, a 44C képen pedig a megfestett mitokondriumok láthatóak. A két kép egymásra vetítése (44D) után nem tapasztaltunk a HMGR2':GFP fehérje és a mitokondrium között kolokalizációt.

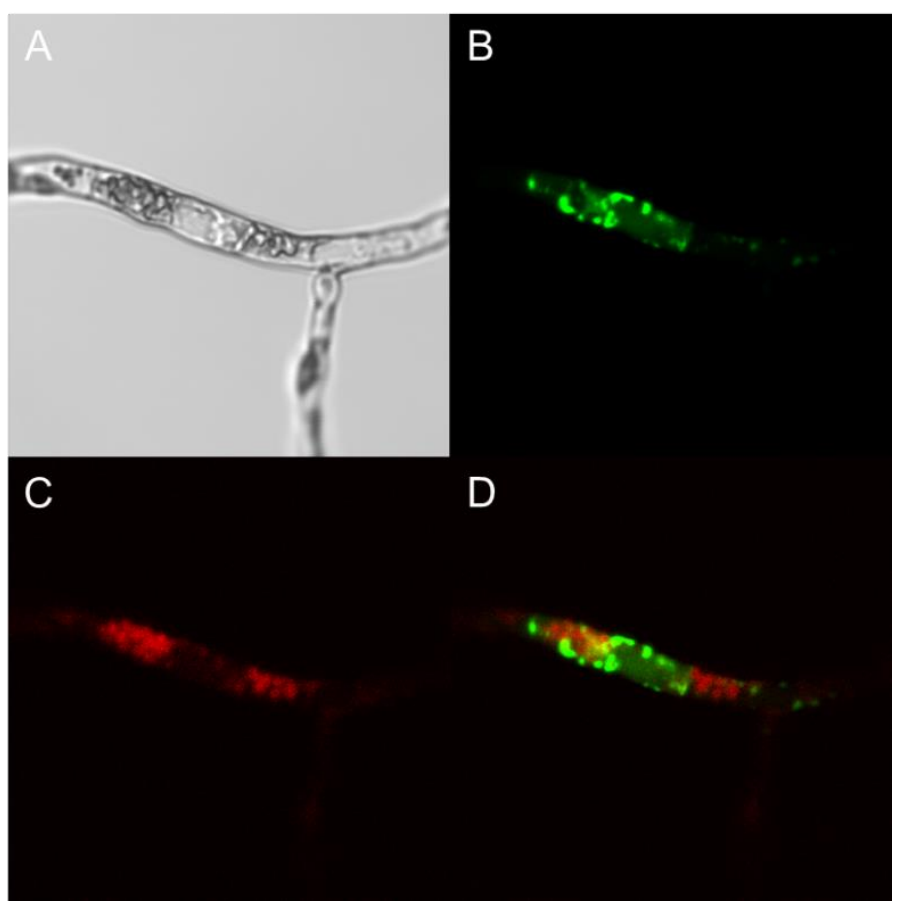

45. ábra. Az MS12-pH2cGFP transzformáns konfokális mikroszkóppal készített felvételei. A; konfokális mikroszkópos kép, B; GFP, C; nile red festés, D; A GFP és a nile red festéssel készült kép egymásra helyezve. 
Annak kiderítésére, hogy mik lehetnek azok az organellumok, ahol még megjelent a HMGR2':GFP fehérje, elvégeztük a sejten belüli lipidcseppek festését is nile red festék felhasználásával (45. ábra). A festék képes a sejten belül a neutrális lipidcseppekket megfesteni, melyek $550 \mathrm{~nm}$ hosszúságú fénnyel gerjesztve piros fluoreszcenciát mutatnak. Hartman és munkatársai (2010) leírták, hogy a HMG-KoA reduktáz szterol indukálta áthelyeződését az ER-ből a citoplazmába lipid cseppek közremüködésével. A festést követően azonban a megfestett lipid cseppekkel sem mutatott kolokalizációt a HMGR2':GFP fehérje. Mivel a HMG-KoA reduktázok és az izoprén bioszintézis egyéb enzimei a peroxiszómákban is lokalizálódhatnak (Breitling és Krisans 2002), lehetséges, hogy a $M$. circinelloides esetében a HmgR2 fehérje peroxiszómálisan is jelen van. Ugyan akkor meg kell említeni, hogy a fehérje aminosav sorrendjének elemzése nem utalt lehetséges peroxiszómális szignálok jelenlétére.

\section{$\underline{\text { MS12-pH3cGFP-1 }}$}

A konfokális mikroszkóppa végzett megfigyelések alapján, láthatóvá válik, hogy a HmgR3':GFP fehérje a sejten belül nagyméretü organellumokban halmozódik fel (46B kép). Egymásra helyezve a GFP és ER festés során készített képeket láthatóvá válik a teljes kolokalizáció a fúziós fehérje és a sejtorganellum között, amit fehér nyilak jelölnek.

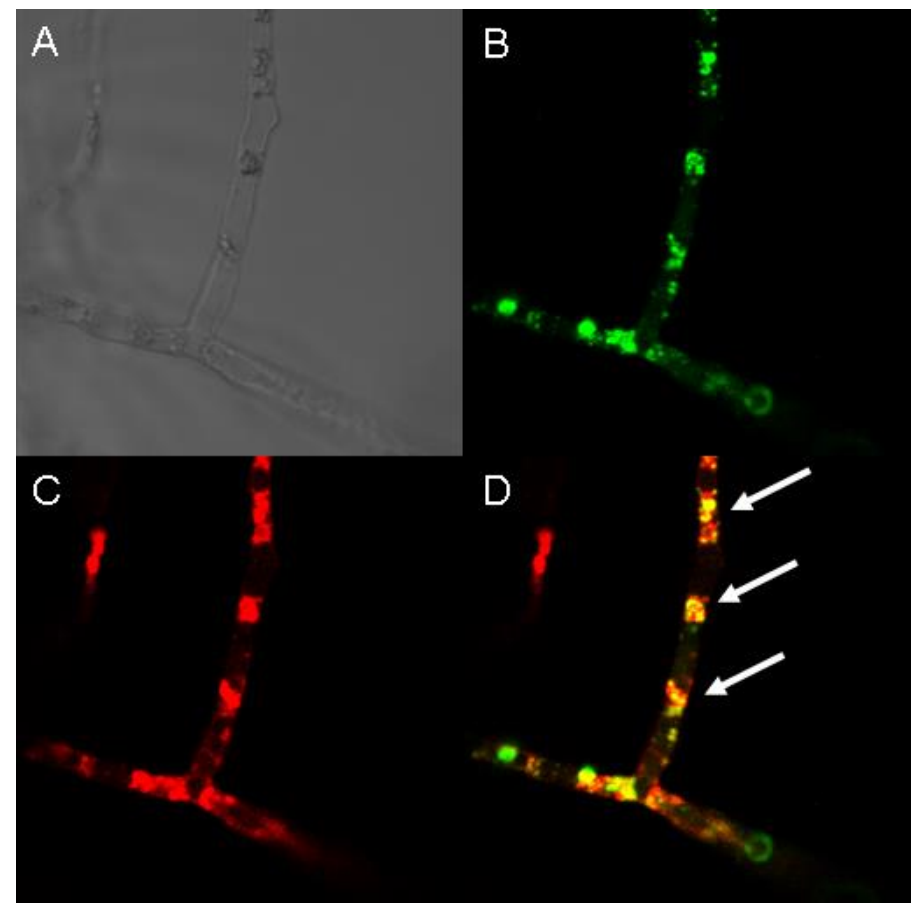

46. ábra Az MS12-pH3cGFP-1 izolátum konfokális mikroszkóppal készített felvétele A:konfokális mikroszkópos kép,B: GFP, C: ER-Tracker Red, D: A GFP és az Er-Tracker Red festéssel készült kép egymásra helyezve. A fehér nyilak jelzik a kolokalizációt. 
Ennél az izolátumnál is elvégeztük a mitokondriumok festését. A 47. ábrán a festést követő konfokális mikroszkóppal készített felvételek láthatóak. A 47D ábrán egymásra vetítve láthatóak a GFP és a Mito-Tracker Red festést követően készített felvételek.

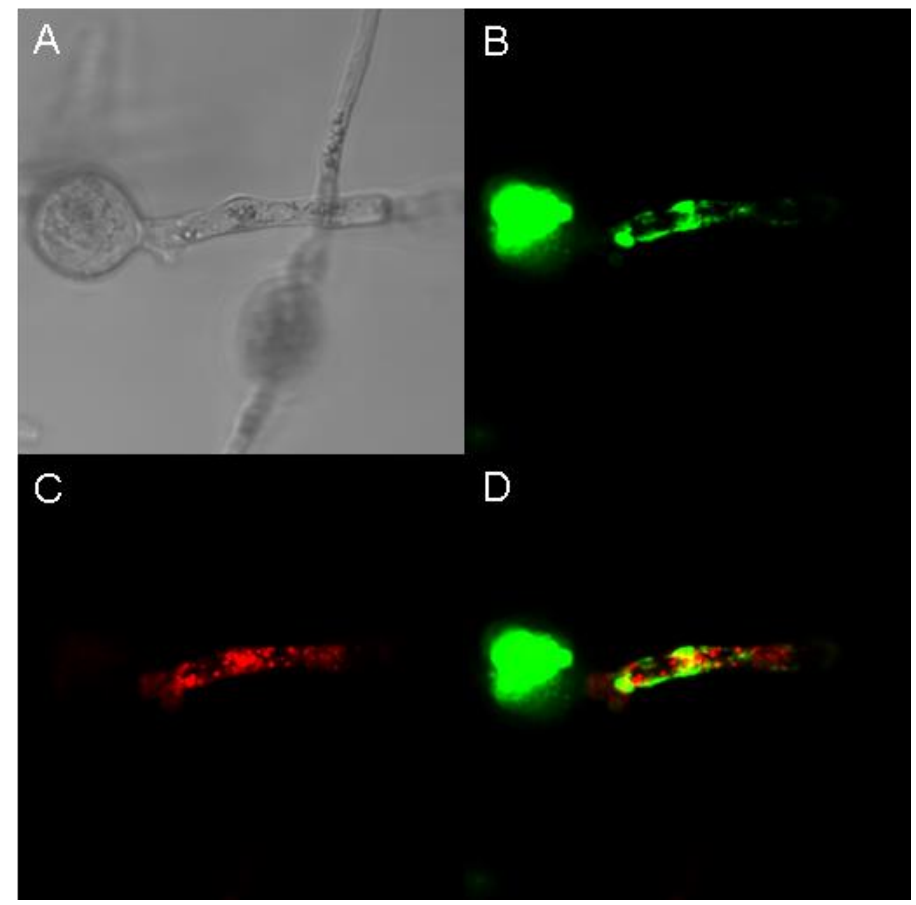

47. ábra Az MS12-pH3cGFP-3 izolátum konfokális mikroszkóppal készített felvétele. A: konfokális mikroszkópos kép,B: GFP, C: MitoTracker Red, D: A GFP és a Mito-Tracker Red festéssel készült kép egymásra helyezve

A konfokális mikroszkópos vizsgálatok arra engednek következtetni, hogy a HmgR3 a sejten belül csak az ER-ben lokalizálódik, míg a HmgR2 megtalálható az ER-ben, ugyanakkor más kisebb méretü kompartmentekben is megtalálható. Annak érdekében, hogy kiderítsük, mik azok a kisméretü partikulumok a sejten belül, további vizsgálatokra van szükség. A fluoreszcens mikroszkóppal végzett megfigyelések továbbá arra engednek következtetni, hogy feltehetőleg a HmgR1 is az ER-ben horgonyzódik ki. Vizsgálataink során a HmgR1':GFP fehérje leginkább a leoltott spórákban és a csíratömlőkben jelent meg. M. circinelloides esetében a leoltástól számított 2. napon kezdődik a spórák termelődése és a sporangiumok kialakulása. A spórák számos mRNS-t és fehérjét tartalmaznak, hogy a csírázás és a csíratömlő képződés időpontjában biztosítani tudják a normális sejtmüködést. Előfordulhat, hogy a HmgR1-nek a spórák képződésében van szerepe, azonban ennek pontos megállapításához további kísérletek szükségesek

A lokalizációs vizsgálatokkal kideríthetjük, hogy a Mucor-ban is hasonló módon történik-e az egyes izoprén származékok szintézise, mint a Phycomyces-ben vagy a Blakeslea-ban. Annak a kérdésnek a megválaszolása, hogy az egyes reduktázoknak van-e 
specifikus szerepe a különbözö izoprének szintézisében hozzásegíthet ahhoz, hogy megfelelö támadáspontot adjunk különböző gombaellenes szerek kifejlesztésére vagy egy adott izoprén túltermelését lehetővé tevő törzs létrehozására. Mindezeken felül képet kaphatunk a Mucor-ban lejátszódó sejtbiológiai folyamatokról és a belső membránrendszerek kialakulásának folyamatáról is. 


\section{7. ÖSSZEFOGLALÁS}

$\mathrm{Az}$ terpének a természetben előforduló legnagyobb és legváltozatosabb vegyületcsoport. Ezen vegyületek olyan több szénatomos molekulák, melyek izoprén egységek összekapcsolódásával keletkeznek. Lehetnek hormonok, illetve hormonhatású vegyületek (pl. gibberellinek, szteroid hormonok), színanyagok (pl. karotinoidok), sejtmembrán alkotók (pl. koleszterin, ergoszterin), illetve másodlagos anyagcseretermékek, mint a szeszkviterpének, vagy a szeszterterpének. A sejtekben is számos sejtbiológiai és biokémiai folyamat részét képzik. Részt vesznek az elektrontranszportláncban, a sejtek közötti kommunikációban és számos fehérje funkciós csoportját adják (pl. RAS). Bioszintézisük gombákban az úgynevezett mevalonsav útvonalon történik. Ezen útvonal során keletkezik az öt szénatomos izopentenil-pirofoszfát (IPP), mely az alapegységét képezi az összes izoprén származéknak.

A mevalonsav bioszintézis útvonal központi, sebesség-meghatározó lépése a 3hidroxi-3-metilglutaril-koenzim A (HMG-KoA) átalakulása mevalonsavvá. Ezt a lépést a HMG-KoA reduktáz katalizálja, így ez az enzim közvetve számos biokémiai és sejtbiológiai folyamatban vesz részt. Fontos szerepe van a környezethez való alkalmazkodásban, az oxigénérzékelésben, egyes gombák esetében kihat a virulenciára és a morfogenezisre. A HMG-KoA reduktáz gén általában egy kópiában fordul elő a genomban, de vannak olyan élőlények, melyekben két vagy több izogén található. $S$. cerevisiae-ben két gént azonosítottak, melyekről két, funkciójában, szabályozásában és a sejten belüli lokalizációjában is eltérő fehérje íródik át. Általában az enzim az ER membránjába ágyazódik, de előfordulhat a mitokondriumban vagy a peroxiszómában is.

Munkánk során a fö célkitüzésünk a $M$. circinelloides HMG-KoA reduktáz génjeinek izolálása és jellemzése volt. Ezért a következő konkrét célokat tűztük ki és valósítottuk meg:

\section{A M. circinelloides HMG-KoA reduktáz génjeinek izolálása és elemzése.}

Munkánk elején a $P$. blakesleeanus és $R$. miehei $h m g R$ génjével kerestünk homológiát mutató szekvenciákat a Mucor genom adatbázisban. Három olyan gént ( $h m g R l$, $h m g R 2$ és $h m g R 3)$ azonosítottunk, amelyek nagyfokú hasonlóságot mutattak az ismert gomba $h m g R$ génekkel. A géneket izoláltuk, majd meghatároztuk a cDNS szekvenciájukat. A $h m g R l$ és $h m g R 2$ esetében 5 intront azonosítottunk, míg a $h m g R 3$ esetében csak kettőt. Elemeztük a kódolt fehérjék feltételezett aminosav szekvenciáit is. Mind három fehérje 
tartalmazza az I. típusú reduktázokra jellemző két fő domént, a variábilis $\mathrm{N}$-terminális régiót és a konzervált C-terminális régiót, valamint a kettőt összekötő, rövid szakaszt. Mindhárom feltételezett fehérjében azonosítottunk a NADPH- és HMG-KoA-kötő motívumokat, valamint szterol érzékelő domént (SSD). Utóbbi felelős a fehérje poszttranszlációs szabályozásáért. A HmgR1 esetében 6, a HmgR2 esetében 9, míg a HmgR3 esetében 5 transzmembrán hélixet azonosítottunk.

\section{A hmgR gének kifejeződésének vizsgálata különböző tenyésztési körülmények} között.

Valós idejű PCR segítségével vizsgáltuk a három $h m g R$ gén kifejeződését különböző tenyésztési körülmények mellett. A vizsgálatok során azt tapasztaltuk, hogy a $h m g R 1$ transzkripciója aerob, a $h m g R 3$ transzkripciója anaerob körülmény között volt erősebb, míg a $h m g R 2$ mind két esetben erős kifejeződést mutatott. A $h m g R l$ kifejeződése a hifákban volt jellemző és kifejeződésének maximumát a leoltástól számított 2. napon érte el. Az egyre növekvő hőmérsékletek hatására a kifejeződése folyamatosan csökkent, ezen kívül reagált a sóstresszre. A $h m g R 2$ és a $h m g R 3$ gének már a csírázó spórákban is aktívak. Szignifikáns hőmérsékletfüggést nem tapasztaltunk a két génnél. Mindkét gén kifejeződését gátolta a maltóz és a nátrium-acetát, mint egyedüli szénforrás. A $h m g R 2$ reagált leginkább a sóstresszre. Eredményeink azt mutatják, hogy a környezeti hatásokra a $h m g R 2$ átíródása változott leginkább.

\section{A hmgR gének kópiaszámának emelése és a gének csendesítése.}

A génekre alapozva, olyan vektorkonstrukciókat hoztunk létre, melyek segítségével megemeltük a gének kópiaszámát (pNG vektorok), illetve csendesítettük (pAS vektorok) azokat. A transzformáció során bejuttatott gének és génszakaszok megfelelő kifejeződése érdekében a Mucor gpd promóter és terminális régióját használtuk. A géncsendesítést antiszensz RNS alapú géncsendesítéssel valósítottuk meg. A létrehozott vektorokkal PEGmediált protoplaszt transzformációt hajtottunk végre, majd a transzformáns telepeket izoláltuk. Megvizsgáltuk a transzformánsok növekedését, makro- és mikromorfológiáját, karotin és ergoszterin tartalmát és a sztatinokkal szembeni érzékenységüket.

A $h m g R l$ gén túlmüködtetésének és csendesítésének hatására jelentős változást egyik vizsgált körülmény mellett sem tapasztaltunk. A transzformáns telepek mikromorfológiájának vizsgálata során plazmakiáramlásokat tudtunk detektálni, de megváltozott hifákat nem. A gén csendesítésének hatására az izolátumok ergoszterin 
tartalma kismértékben csökkent a vad típusú törzshöz képest. Apoptózis festést követően, mindkét típusú transzfománsban azonosítottunk nekrotikus hifákat és sejteket. A $h m g R 2$ gén túlmüködtetésének hatására nőtt a transzformánsok karotin és ergoszterin tartalmuk, valamint csökkent a sztatinokkal szembeni érzékenységük. A gén csendesítése szintén plazmakiáramlásokhoz vezetett, valamint csökkent az izolátumok ergoszterin tartalma is. Az esetleges apoptotikus folyamatok detektálása során itt is találtunk nekrotikus sejteket és hifarészeket. A legtöbb változást a $h m g R 3$ gén esetében tapasztaltuk. A gén kópiaszámának emelése hatására ezekben a transzformánsokban nőtt leginkább a karotinoid tartalom és csökkent a sztatinokkal szembeni érzékenység. A gén csendesítésének hatására a transzformánsok makromorfológiája szabálytalanná vált, a hifák megduzzadtak, a hifák elágazásainak száma megnőtt és számos plazmakiáramlást azonosítottunk. Az ergoszterin szint és a karotinoid szint jelentősen lecsökkent. Apoptózis festést követően az apoptózis korai fázisát és a nekrózist is ki tudtuk mutatni. A csendesített transzformánsok spóráinak csírázó képessége is megváltozott.

\section{Az egyes HmgR fehérjék sejten belüli lokalizációja.}

A M. circinelloides HMG-KoA reduktázainak sejten belüli lokalizációjának vizsgálatához a reduktázok transzmembrán régióit GFP-vel fuzionáltattuk. A fúziós fehérjék segítségével nyomon tudtuk követni a fehérjék sejten belüli lokalizációját. A létrehozott vektorokkal PEG-mediált protoplaszt transzformációt hajtottunk végre, majd a transzformáns telepeket izoláltuk. A transzformánsok elemzését fluoreszcens mikroszkópiával kezdtük meg, melynek során azt tapasztaltuk, hogy mindhárom fehérje a sejten belül egy nagyméretü organellumban lokalizálódik, illetve a HmgR2 emellett számos kisebb, jól körülhatárolható kompartmentben is megjelent. Ahhoz, hogy a fehérjék pontos lokalizációját meghatározzuk endoplazmatikus retikulum és mitokondrium festést alkalmaztunk, majd a festett mintákat konfokális mikroszkóppal vizsgáltuk. A HmgR2 és a HmgR3 a festéseket követően egyértelmü kolokalizációt mutatott az endoplazmatikus retikulummal, azonban a mitokondriummal nem.

\section{Vizsgálataink során a következő fö hasonlóságokat és különbségeket} azonosítottuk a $M$. circinelloides három $\mathbf{h m g R}$ génje között:

A hmgRl gén aerob körülmények között íródik át, csak a hifákban és a spóraképződés időszakában. A gén relatív transzkripciós szintje a $h m g R 2$-nél és $h m g R 3$-nál mért értékekhez viszonyítva igen alacsony, és csak ennél a génnél mutattunk ki 
hőmérsékletfüggő transzkripciót. Anaerob körülmények között a gén aktivitása jelentősen lecsökken. A gén megváltozott müködésének hatására (kópiaszámának emelése, csendesítése) a gomba karotinoid és ergoszterin termelése nem változott, ugyanakkor hatással lehet a citoplazma membrán integritására. A HmgR1 fehérje jellemzően a spórákban és csíratömlőben jelenik meg és feltehetőleg az endoplazmatikus retikulum membránjába ágyazódik.

A $h m g R 2$ gén aerob és anaerob tenyésztési körülmények mellett erős aktivitást mutatott, valamint relatív transzkripciós szintjét összehasonlítva a másik két gén értékeivel megállapítottuk, hogy az anaerob tenyésztést leszámítva e gén a legaktívabb a három reduktáz gén közül. A spórák csírázásának idején és az intenzív micéliumképzés során relatív transzkripciós szintje magas. A növekvő sókoncentráció változásával párhuzamosan nőtt a relatív transzkripciós szintje, azonban a szénforrások közül a trehalóz és a maltóz gátolta a kifejeződését. A gén túlműködtetésének hatására a transzformáns törzsek karotinoid és ergoszterin tartalma jelentősen megnőtt, ugyanakkor a sztatinokkal szembeni érzékenysége lecsökkent. Mivel a HMG-KoA reduktáz az ergoszterin bioszintézisben is központi jelentőséggel bír, a HmgR2 funkcionális vizsgálata hasznos lehet új, a patogén gombákkal szembeni szerek kifejlesztése és terápiás célpontok megtalálása szempontjából is. Az ergoszterin bioszintézis a gombaellenes terápiák egyik legfontosabb célpontja. Újabban HMG-KoA reduktáz gátlók alkalmazási lehetőségét is intenzíven kutatják (Galgóczy és mtsi. 2011). A gén csendesítésének hatására csökkent a karotinoid és ergoszterin mennyisége, valamint a citoplazma membrán integritásában is zavarok keletkeztek. A HmgR2 fehérje a sejten belül az endoplazmatikus retikulum membránjában helyezkedik el, azonban a konfokális mikroszkópos vizsgálatok nem zárják ki más, kisebb méretű kompartmentekben történő lokalizációját sem.

A $h m g R 3$ gén kifejeződését nagyban befolyásolja a környezet oxigéntartalma, ugyanis anaerob körülmények között megnő a gén relatív transzkripciós szintje. A gén terméke fontos a spórák csírázásának idején, valamint a spóraképződés időpontjában. Hőmérsékletfüggést, mint a $h m g R l$ esetében, vagy szerepet az ozmotikusan megváltozott környezethez való adaptálódáshoz, mint a $h m g R 2$ esetében, nem találtunk. Leginkább e gén terméke befolyásolta a termelődő karotinoid mennyiséget és az ergoszterol bioszintézisre is hatással volt. A gén csendesítése csökkentette leginkább a termelődő ergoszterol tartalmat. A $h m g R 3$ és a $h m g R 2$ felhasználható a karotinod bioszintézis fokozására és esetleg egy, az iparban is alkalmazható karotinoidtermelő törzs létrehozására. A gén csendesítésének hatására a termelődő karotinoid mennyiség jelentősen lecsökkent, a gomba makro- és 
mikromorfológiája megváltozott, valamint apoptotikus folyamatok játszódtak le a sejtekben. A spórák elvesztették csírázóképességüket és a csírázás ideje jelentősen kitolódott. A járomspórás gombákban lezajló apoptotikus folyamatokról igen keveset tudunk, emiatt a gén kiváló célpontja lehet az ezirányú kutatásoknak.

Kutatásaink nyomán új információval bővültek ismereteink a M. circinelliodesben zajló terpén bioszintézisről. Eredményeink hozzájárulhatnak a járomspórás gombák morfogenezisének, valamint a sejten belül lejátszódó apoptotikus és stresszválasz útvonalak felderítéséhez. Továbbá ezen eredmények felhasználhatóak a Mucor-ban zajló karotinoid és ergoszerin bioszintézis szabályozásának tanulmányozására, így hozzájárulhatnak az iparban is alkalmazható karotinoid termelő törzsek előállításához, valamint hatékony gombaellenes szerek kifejlesztéséhez. Vizsgálataink során sikeresen alkalmaztuk a GFP-t a reduktázok sejten belüli lokalizációjának vizsgálatához. 


\section{SUMMARY}

Mucor circinelloides is a carotene producing zygomycete fungus, which has been used as a model organism in studies of the carotenoid biosynthesis. Terpenoids are one of the most diverse group of natural chemical compounds. They are synthesized from two or more isoprene units. They have different biological functions, such as hormones or hormonelike compounds (e.g. gibberellins in plants or steroid hormones in animals), colorants (e.g. carotenoids), cell membrane components (e.g. cholesterol and ergosterol) and several types of secondary metabolic products, among others di-, sesqui- or sesterterpenoids. In cells, they have role in different cell biological and biochemical processes. They can participate in the electron transport chain, in cell-cell communication and give functional groups of certain proteins (e.g. RAS). Isopentenyl pyrophosphate (IPP) is the basic building unit of all isoprene derivatives, which is synthesized via the mevalonic acid pathway.

The central, rate limiting step of this pathway is the conversation of 3-hydroxy-3methylglutaryl coenzyme A (HMG-CoA) to mevalonic acid, catalysed by the enzyme HMGCoA reductase. Through to the formation of the many different terpenoids, HMG-CoA reductase has an important role in the adaptation to the environmental changes, virulence and morphogenesis. Usually only one HMG-CoA reductase gene occurs in the genome, but some organisms have two or more reductase genes. In the S. cerevisiae genome, two HMGCoA reductase genes were identified with different functions, regulations and subcellular localizations. Generally, this enzyme is an endoplasmic reticulum-anchored protein, but it may also be present in the mitochondria or the peroxisomes.

The main goal of the present study was the isolation and characterization of the HMG-CoA reductase genes of $M$. circinelloides. Therefore, the following specific objectives were set and implemented:

\section{Isolation and characterization of $M$. circinelloides HMG-CoA reductase genes.}

Using the $h m g R$ genes of $P$. blakesleeanus and $R$. miehei, searches for homologous sequences were performed in the genome database of $M$. circinelloides f. lusitanicus. Three $h m g R$ genes ( $h m g R 1, h m g 2$ and $h m g R 3)$ were identified. The genes were isolated and their cDNA sequences were determined. In $h m g R l$ and $h m g R 2$, five introns were identified, while $h m g R 3$ had only two introns. We analysed the amino acid sequences of the putative proteins as well. All three proteins belong to type I reductases with two main domains, the variable 
$\mathrm{N}$-terminal region and the conserved $\mathrm{C}$-terminal region. Between them, there is a short linker region. $\mathrm{NAD}(\mathrm{P}) \mathrm{H}$ and $\mathrm{HMG}-\mathrm{CoA}$ binding motifs and the sterol sensing domain (SSD) could be identified in all three proteins. SSD is responsible for the post-translational regulation of proteins. In $h g m R l$ one, in $h m g R 2$ nine, while in $h m g R 3$ five transmembrane helix were identified.

\section{Analysis of the transcription of the $h m g R$ genes under different growth conditions.}

The relative transcription levels of the three $h m g R$ genes were determined under various culture conditions by quantitative real-time PCR. It was found that $h m g R l$ is transcribed only under aerobic conditions. At the same time, the transcription level of $h m g R 3$ was relatively high under anaerobiosis, while $h m g R 2$ showed high transcription under both conditions. Expression of $h m g R l$ was detected only in the hyphae and reached the maximum level at 48 hours after inoculation showing a temperature-dependent transcription.

In the germinating spores $h m g R 2$ and $h m g R 3$ were active and did not show temperature dependence. Expression of both genes was inhibited by maltose and trehalose and $h m g R 2$ responded to salt stress. Our results show that transcription of $h m g R 2$ was highly affected by the environmental factors.

\section{Over-expression and silencing of the $h m g R$ genes.}

Two different types of vectors were constructed, one series of vectors was built to overexpress the $h m g R$ genes by elevating the copy number and changing their promoter to that of the gpdl gene (pNG series) and another series to silence them by antisense RNAbased gene silencing (pAS series). Vectors were transformed into the recipient MS12 strain using the PEG-mediated protoplast transformation method and transformed colonies were isolated. After analysis of the transformants to prove the presence of the transformed DNA, growing rate, macro- and micromorphology, carotenoid and ergosterol content and sensitivity to statins were tested.

Over-expression and silencing of $h m g R l$ had no significant effect to the majority of the examined features. However, cytoplasm effusions could be detected during the microscopic examination of the silenced transformants and their ergosterol content was slightly decreased. In both types of transformants, necrotic cells and hyphae were detected.

Over-expression of $h m g R 2$ resulted in increased carotenoid and ergosterol contents and decreased sensitivity to statins in the transformants. Silencing of the gene also led to cytoplasm effusions and we could detect necrotic cells and hyphae as well. 
Similarly to the changes detected in case of $h m g R 2$, over-expression of $h m R 3$ increased the carotenoid and ergosterol content and decreased the sensitivity to statins of the transformants. Silencing of this gene caused altered morphology in the transformants with irregular, swollen hyphae and cytoplasm effusions and increased hyphal branching. Carotenoid and ergosterol content decreased significantly in these strains and we could detect the early stage of apoptosis. It seems that $h m g R 3$ has role in spore germination and morphogenesis.

\section{Subcellular localization of the HmgR proteins.}

To analyse the subcellular localization of the HmgR proteins, the transmembrane region of each reductase was fused with green fluorescent protein (GFP). With these fusion proteins we could follow the localization of reductases in the cell. After PEG mediated protoplast transformation the transformed colonies were isolated. We have started to analyse the transformed strains with fluorescent microscopy and it was found that all three proteins are localized in large regions in the cell, but the HmgR2 also appeared in a number of not well-defined compartments. To get the exact localization of the proteins we stained the endoplasmic reticulum and the mitochondria, and samples were analysed by confocal microscopy. The HmgR2 and HmgR3 showed a clear co-localization to the endoplasmic reticulum, but not to the mitochondria.

\section{The following main features of the $M$. circinelloides $\mathbf{h m g R}$ genes and the encoded} proteins were observed in this study:

Under aerobic conditions the $h m g R l$ gene is active in the hyphae and during the sporulation. Relative transcription level of this gene was significantly lower than those of the $h m g R 2$ and $h m g R 3$. Temperature dependent gene expression was observed only in case of $h m g R l$. Under anaerobic conditions the activity of this gene significantly decreased. Ergosterol and carotenoid production of fungus was not affected by the altered expression of the gene (i.e. increase of the copy number or silencing), but it may have role in cytoplasmic integrity. HmgR1 typically appeared in spores and germ tubes and possibly localizes to the endoplasmic reticulum.

$H m g R 2$ displayed strong transcription activity under aerobic and anaerobic conditions and this gene showed the highest transcription level under aerobic cultivation condition during the whole life cycle of the fungus. Relative transcription level of this gene was also high during the germination of the spornagiospores. Expression of $h m g R 2$ increased 
proportionally with increasing salt concentration, but trehalose and maltose decreased the transcription activity. Overexpression of the gene significantly increased the carotenoid and ergosterol content of the transformants and decreased their sensitivity to statins. Ergosterol biosynthesis is one of the most important target for antifungal therapies and HMG-CoA reductase inhibitors are intensively researched (Galgóczy et al. 2011). As HMG-CoA reductase has important role in ergosterol biosynthesis, functional testing of $h m g R 2$ may be useful in finding and developing new antifungal agents. With the silencing of the gene, carotenoid and ergosterol content of the transformant strains decreased and cytoplasmic integrity was also effected. HmgR2 is associated in the endoplasmic reticulum but may also be localized in other small compartments in the cell.

Oxygen content of the environment affected the expression of $h m g R 3$; relative transcription level of the gene significantly increased under anaerobic conditions. Expression of the gene seems to be important during spore germination and sporulation. Temperature dependent gene expression or response to osmotically changed environment were not found but maltose and trehalose inhibited the gene epxression. HmgR3 plays important role in the carotenoid biosynthesis and it also has influence in the ergosterol biosynthesis. $H m g R 3$ and $h m g R 2$ may be possible targets to create new carotenoid producing strains. Silencing the $h m g R 3$ gene significantly decreased the carotenoid content of transformants; macromorphology of strains changed and we could detect apoptosis-like processes. Spores of the silenced strains lost germinating ability and germination time was delayed. In zygomycetes, apoptotic processes are not investigated, so $h m g R 3$ can be an excellent target for such studies. It seems HmgR3 localizes in the endoplasmic reticulum.

As a result of our research, new information was obtained about the terpene biosynthesis of $M$. circinelloides. Our results also contribute to the investigation of morphogenesis, detection of cell stress response pathway and apoptotic processes in Mucor. Furthermore, the results can be used to analyse the regulation of the carotenoid and ergosterol biosynthesis in this organism and to develop new carotenoid producer strains for the industry, as well as in studies to find new targets for antifungal therapy. 


\section{IRODALOMJEGYZÉK}

Aboushadi N., Shackelford J.E., Jessani N., Gentile A., Krisans S.K. (2000) Characterization of peroxisomal 3-hydroxy-3-methylglutaryl coenzyme A reductase in UT2 cells: sterol biosynthesis, phosphorylation, degradation, and statin inhibition. Biochemistry 39(1): 237-247.

Agarwall B., Hendwall S.B., Halmos B., Moss S.F., Ramey W.G., Holt P.R. (1999) Lovastatin augments apoptosis induced by chemotherapeutic agents in colon cancer cells. Clin. Cancer. Res. 5: 2223-2229.

AlcaZar-Fuoli L., Mellado E., Garcia-EfFron G., Lopez J.F., Grimalt J.O., CuencaEstrella J.M., RodrigueZ-Tudela J.L. (2008) Ergosterol biosynthesis pathway in Aspergillus fumigatus. Steroids 73: 339-347.

Anrade-Pavón D., SÁnchez-SAndoval E., Rosales-Acosta B., Ibarra J.A., TAmirez J., HERNÁNDEZ-RODRÍGUEZ C., VILLA-TANACA L. (2013) The 3-hydroxy-3-methylglutaryl coenzyme-A reductases from fungi: A proposal as a therapeutic target and as a study model. Rev. Iberoam. Micol. 31(1): 81-85.

BARKLEY S.J., CORNISH R.M., POULTER C.D. (2004) Identification of an archaeal type II iopentenyl diphosphate isomerase in Methanothermobacter thermautotrophicus. $J$. Bacteriol. 186: 1811-1817.

BAsson M.E., Moore, R.L., O'ReAr J., Rine J. (1987) Identifying mutations in duplicated functions in Saccharomyces cerevisiae: Recessive mutations in HMG-CoA reductase genes. Gen. Society America 117: 645-655.

BASSON M.E., THORSNESS M., RINE J. (1986) Saccharomyces cerevisiae contains two functional genes encoding 3-hydroxy-3-methylglutaryl-coenzyme A reductase. Proc. Natl. Acad. Sci. USA 83: 5563-5567.

Basson M.E., Thorsness M.K., Finer-Moore J., Stroud R. AND Rine J. (1988) Structural and functional conservation between yeast and human 3-hydroxy-3methylglutaryl-coenzyme reductases, the rate-limiting enzyme of sterol biosynthesis. Mol. Cell. Biol. 9: 3797-3808.

BEJARANO, E.R. AND CERDÁ-OLMEDO, E. (1992) Independence of the carotene and sterol pathways of Phycomyces. FEBS Lett. 306(2-3): 209-212.

BENNY G.L. (2001) Zygomycota: Trichomycetes. Systematics and Evolution. The Mycota. McLaughlin D.J., McLaughlin K.G., Lemke P.A. (ed.), Springer-Verlag, Berlin, Heidelberg, Vol. VII PartA, pp. 147-160.

BenNy G.L., Humber R.A., Morton J.B. (2001) Zygomycota: Zygomycetes. Systematics and Evolution. The Mycota. McLaughlin D.J., McLaughlin K.G., Lemke P.A. (ed.), Springer-Verlag, Berlin, Heidelberg, Vol. VII PartA, pp. 113-146. 
Bhosale P. (2004) Environmental and cultural stimulants in the production of carotenoids from microorganisms. Appl. Microbiol. Biotechnol. 63: 351-361.

Bidle K.A., Hanson T.E., Howel K., NAnnen J. (2007) HMG-CoA reductase is regulated by salinity at the level of transcription in Haloferax volcanii. Extremophiles 11: 49-55.

Boguski M.S., McCoRMick F. (1993) Proteins regulating Ras and its relatives. Nature 366(6456): 643-654.

Bourne H.R., SAnders D.A., MCCORMICK, F. (1990) The GTPase superfamily: a conserved switch for diverse cell functions. Nature 348(6297): 125-132.

BREITLING R., KRISANS S.K. (2002) A second gene for peroxisomal HMG-CoA reductase? A genomic reassessment. J. Lipid Resch. 43: 2031-2036.

Britton G., LiAAEN-Jensen S., PfAnder H. (2008) Carotenoids-Natural functions, Vol. 4. Birkhauser Verlag, Basel, Boston, Berlin.

BRown M.S., GoldSTEIN J.L. (1999) A proteolytic pathway that controls the cholesterol content of membranes, cells, and blood. Proc. Natl. Acad. Sci. USA. 96(20): 11041-11048.

Burg J.S., ESPENSHADE P.J. (2011) Regulation of HMG-CoA reductase in mammals and yeast. Prog. Lipid Res. 50: 403-410.

BURMESTER A., CZEMPINSKI K. (1994) Sequence comparison of a segment of the gene for 3-hydroxy-methylglutaryl-coenzyme A reductase in zygomycetes. Eur. J. Biochem. 220: 403-408.

Burton G.W. (1989) Antioxidant action of carotenoids. J. Nutrition 119: 109-111.

Caelles C., Ferrer A., Balcells L., Hegardt F.G., Boronat A. (1989) Isolation and structural characterization of a cDNA encoding Arabidopsis thaliana 3-hydroxy-3methylglutaryl coenzyme A reductase. Plant Mol. Biol. 13(6): 627-38.

Cardoza R.E., Hermosa M.R., Vizcaíno J.A., GonzÁlez F., Llobell A., Monte E., GutiÉRrez S. (2007) Partial silencing of a hydroxy-methylglutaryl-CoA reductaseencoding gene in Trichoderma harzianum CECT 2413 results in a lower level of resistance to lovastatin and lower antifungal activity. Fungal Genet. Biol. 44: 269-283.

CARTER J.P. (1988) Gamma-linoleic acid as a nutrient. Food Technol. 6: 72-82.

Chamilos G., Lewis R.E., KonTOYIANNIS D.P. (2006) Lovastatin has significant activity against Zygomycetes and interacts synergistically with voriconazole. Antimicrob. Agents Chemother.50(1): 96-103.

Chandra L.T., Deeba P., Talib D., Renee M.G., Randolph Y.H. (2011) The Sterolsensing Domain (SSD) Directly Mediates Signal-regulated Endoplasmic Reticulumassociated Degradation (ERAD) of 3-Hydroxy-3-methylglutaryl (HMG)-CoA Reductase Isozyme Hmg2. J. Biol. Chem. 286(30): 26298-26307. 
Chayakulkeeree M., Ghannoum M.A., Perfect J.R. (2006) Zygomycosis: the reemerging fungal infection. Eur. J. Clin. Microbiol. Infect. Dis. 25: 215-229.

CHEW B.P. (1993) Role of carotenoids in the immune response. J. Dairy Sci. 76: 28042811.

Chew B.P., PARK J.S., Wong M.W., WONG T.S. (1999) A comparison of the anticancer activities of dietary $\beta$-carotene, canthaxanthin and astaxanthin in mice in vivo. Anticancer Res. 19: 1849-1853.

Croxen R., Goosey M.W., KeON J.P., HARgreaves J.A. (1994) Isolation of an Ustilago maydis gene encoding 3-hydroxy-3-methylglutaryl-coenzyme $A$ reductase and expression of a C-terminal-truncated form in Escherichia coli. Microbiology 140(9): 2363-2370.

DAVIES J.P. AND IOANNOU Y.A. (2006) The role of the Niemann-Pick C1-like 1 protein in the subcellular transport of multiple lipids and their homeostasis. Curr. Opin. Lipidol. Review. 17(3): 221-226.

Dellas N., Thomas S.T., Manning G., Noel J.P. (2013) Discovery of a metabolic alternative to the classical mevalonate pathway. eLife DOI: $10.7554 /$ Life.00672

Dimster-DenK D., RINE J. (1996) Transcriptional regulation of a sterol-biosynthetic enzyme by sterol levels in Saccharomyces cerevisiae. Mol. Cell Biol. 16: 3981-89.

Dufossé L. (2006) Microbial Production of Food Grade Pigments. Food Technol. Biotechnol. 44(3): 313-321.

Dufossé L. (2009) Microbial and Microalgal Carotenoids as Colourants and supplements. In: Carotenoids Volume 5: Nutrition and Health, Britton, G., Liaaen-Jensen, S., Pfander, H. (Eds.) Springer Science \& Business Media pp. 83-98.

Dutoit R., De RuYyck J., Durisotti V., Legrain C., Jacobs E., Wouters J. (2008) Overexpression, physicochemical characterization, and modelling of a hyperthermophilic Pyrococcus furiosus type 2 IPP isomerise. Proteins 71: 1699-1707.

Ellis R.W., Defeo D., Shin T.Y., Gonda M.A., Young H.A., Tsuchida N., Lowy D.R., SCOLNICK E.M. (1981) The p21 src genes of Harvey and Kirsten sarcoma viruses originate from divergent members of a family of normal vertebrate genes. Nature 292(5823): 506-511.

Engfelt W.H., Shackelford J.E., Aboushadi N., Jessani N., Masuda K., Paton V.G., Keller G.A., Krisans S.K. (1997) The characterization of the UT-2 cells. The induction of peroxisomal 3-hydroxy-3-methylglutaryl coenzyme A. J. Biol. Chem. 272: 24579-24587.

ESPENSHADE P.J. (2006) SREBPs: sterol-regulated transcription factors. J. Cell Sci. 119: 973-76.

FRIESEN J.A., RODWELL V.W. (2004) The 3-hydroxy-3-methylglutaryl coenzyme-A (HMG-CoA) reductase. Proteins 71: 1699-1707. 
Galgóczy L., Nyilasi I., PAPP T., VÁGVÖlgyi Cs. (2009) Are statins applicable for the prevention and treatment of zygomycosis? Clin. Infect. Dis. 49: 483-484.

Galgóczy L., LuKÁCs G., NYILASI I., PAPP T., VÁGVÖLGYi Cs. 2010 Antifungal activity of statins and their interaction with amphotericin $B$ against clinically important Zygomycetes. Acta. Biol. Hung. 61(3): 356-365.

Gasteiger E., Hoogland C., Gattiker A., Duvaud S., Wilkins M.R., Appel R.D., BAIROCH A.(2005) Protein Identification and Analysis Tools on the ExPASy Server. The Proteomics Protocols Handbook John M. Walker (ed): Humana Press pp. 571-607

Genschik P., Criqui M-C., Parmentier Y., Marbach J., Durr A.,Fleck J., Jamet E. (1992) Isolation and characterization of a cDNA encoding a 3-hydroxy-3methylglutaryl coenzyme A reductase from Nicotiana sylvestris. Plant Mo1. Biol. 20 : 337-341.

Gertler FB., ChOI-Ying C., Richter-Mann L., Chin DJ. (1988) Developmental and metabolic regulation of the Drosophila melanogaster 3-hydroxy-3-methylglutaryl coenzyme A reductase. Mol. Cell. Biol. 8: 2713-2721.

Ghormade V., Pathan E., DeshPande M.V. (2012) Yeast-hypha dimorphism in Zygomycetous fungi. Dimorphic fungi: Their importance as models for differentiation and fungal pathogenesis. Ruiz-Herrera J. (ed): Bentham eBooks ISBN: 978-1-60805-510-4 pp. 87-105.

GodTfRedsen S.E. (1990) Microbial lipases. Microbial enzymes and biotechnology. Fogarty W.M., Kelly C.T. (ed.): 2nd ed., Elsevier, London, UK, pp. 255-274.

GoldSTEIN J.L. AND BROWN M.S. (1990) Regulation of the mevalonate pathway. Nature 343: 425-430.

GoOdAy G.W. (1994) Hormones in mycelial fungi. Growth, Differentiation and Sexuality, The Mycota. Wessels J.G.H., Meinhardt F. (ed.), Vol. I. Springer-Verlag, Berlin, pp. 401411.

GrygAnskyi A.P., MusZEWSKA A. (2014) Whole genome sequencing and the Zygomycota. Fungal Genom. Biol. 4(1): http://dx.doi.org/10.4172/2165-8056.1000e116

HAMBrock A., LÖFfler-WAlz C., QuAST U. (2002) Glibenclamide binding to sulphonylurea receptor subtypes: dependence on adenine nucleotides. Br. J. Pharmacol. 136(7): 995-1004.

HAMPTON R.Y., RiNE J. (1994) Regulated degradation of HMG-CoA reductase, an integral membrane protein of the endoplasmatic reticulum in yeast. J. Cell. Biol. 125: 299-312.

Han B.Z., Rombouts F.M., Nout M.J.R. (2001) A Chinese fermented soybean food. Int. J. Food. Microbiol. 65: 1-10. 
Heidl M., Tabernero L., Stauffacher C.V., Rodwell V.W. (2004) Class II 3-hydroxy3-methylglutaryl-coenzyme-A reductase. J. Bacteriol. 188: 3192-3198.

HenneKens C.H., Mayrent S.L., Willett W. (1986) Vitamin A, carotenoids, and retinoids. Cancer 58(8 Suppl): 1837-1841.

Hibbett D.S., Binder M., Bischoff J.F., Blackwell M., CANNON P.F. ÉS MTSI. (2007) A higher-level phylogenetic classification of the Fungi. Mycol. Resch. 111 (5): 509-547.

Hofmann, K., Stoffel, W. (1993). TMbase - A database of membrane spanning proteins segments. Biol. Chem. Hoppe-Seyler 347: 166.

HoRnby J.M., Jensen E.C., Lisec A.D., TAsto J.J., JahnKe B., ShOEmaKer R., DusSault P., NICKERSON K.W. (2001) Quorum sensing in the dimorphic fungus Candida albicans is mediated by farnesol. Appl. Environ. Microbiol. 67 (7): 2982-2992.

Horton J.D., Goldstein J.L., BRown M.S. (2002) SREBPs: activators of the complete program of cholesterol and fatty acid synthesis in the liver. J. Clin. Invest. 109: 11251131.

Hughes A.L., LeE C.Y., BIEN C.M., EsPenshade P.J (2007) 4-methyl sterols regulate fission yeast SREBP-Scap under low oxygen and cell stress. J.Biol. Chem. 282(33): 24388-96.

Hughes A.L., TodD B.L., EsPenshade P.J. (2005) SREBP pathway responds to sterols and functions as an oxygen sensor in fission yeast. Cell 120: 831-42.

IstVan E.S., PALnitKar M., Buchanan S.K., Deisenhofer J. (2000) Crystal structure of the catalytic portion of human HMG-CoA reductase: insights into regulation of activity and catalysis. EMBO J. 19(5): 819-830.

Iturriaga E.A., Díaz-Minguez J.M., Benito E.P., Álvarez M.I., Eslava A.P. (1992) Heterologous transformation of Mucor circinelloides with the Phycomyces blakesleeanus leu1 gene. Curr. Genet. 21: 215-223.

Iturriaga E.A., Papp T., Breum J., Arnau J., Eslava A.P. (2005) Strain and culture conditions improvement for $\beta$-carotene production in Mucor. Microbial Processes and Products. Methods in Biotechnology. Barredo, J.-L. (ed.), Humana Press, USA, Vol. XVIII, pp. 239-256.

Iturriaga E.A., Velayos A., Eslava A.P. (2000) Structure and function of genes involved in the biosynthesis of carotenoids in the Mucorales. Biotechnol. Bioprocess Eng. 5: 263-274.

Iturriaga E.A., Velayos A., Eslava A.P., Alvarez M.I. (2001) The genetics and molecular biology of carotenoid biosynthesis in Mucor. Recent Res. Dev. Genet. 1: 7992.

Johnson E.A. AND Schroeder W.A. (1995) Microbial carotenoids. Adv. Biochem. Eng. Biotech. 53: 119-178. 
JoO J.H., JETTEN A.M. (2010) Molecular mechanisms involved in farnesol-induced apoptosis. Cancer lett. 287(2): 123-35.

Kaneda K., Kuzuyama T., Takagi M., Hayakawa Y., Seto H. (2001) An unusual isopentenyl diphosphate isomerase found in the mevalonate pathway gene cluster from Streptomyces sp. strain CL190. Proc. Natl. Acad. Sci. U S A. 98(3): 932-937.

Kataoka T., Powers S., McGill C., Fasano O., Strathern J., Broach J. AND Wigler M. (1984) Genetic analysis of yeast RAS1 and RAS2 genes. Cell 37(2): 437-445.

KELLER G.A., PAZIRANDEH M., KRISANS S. (1986) 3-Hydroxy-3-methylglutaryl coenzyme A reductase localization in rat liver peroxisomes and microsomes of control and cholestyramine-treated animals: Quantitative biochemical and immunoelectron microscopical analyses. J. Cell Biol. 103: 875-886.

Koning A.J., Roberts C.J., WRIGHT R.L. (1996) Different subcellular localization of Saccharomyces cerevisiae HMG-CoA reductase isozymes at elevated levels corresponds to distinct endoplasmic reticulum membrane proliferations. Mol. Biol. Cell 7: 769-789.

KuZina V., CERdÁ-Olmedo E. (2007) Ubiquinone and carotene production in the Mucorales Blakeslea and Phycomyces. Appl. Microbiol. Biotechnol. 76: 991-999.

Kuzina V., Domenech C., CerdÁ-Olmedo E. (2006) Relationships among the biosyntheses of ubiquinone, carotene, sterols, and triacylglycerols in Zygomycetes. Arch. Microbiol. 186: 485-49.

LEARNED R.M., FINK G.R. (1989) 3-Hydroxy-3-methylglutaryl-coenzyme A reductase from Arabidopsis thaliana is structurally distinct from the yeast and animal enzymes. Proc. Natl. Acad. Sci. USA 86(8): 2779-2783.

Leivar P., GonzÁles V.M., Castelas S., Trelease R.N., LóPez-Iglesias C., ArRó M., Boronat A., CAmpos N., Ferrer A., Fernández-Busquets X. (2005) Subcellular localization of Arabidopsis 3-hydroxy-3-methyl-glutaryl-coenzyme A reductase. Plant Phys. 137: 57-69.

Liscum L., Finer-Moore J., Stroud R.M., Luskey K.L., Brown M.S., GoldSTein J.L. (1985) Domain structure of 3-hydroxy-3-methylglutaryl coenzyme A reductase, a glycoprotein of the endoplasmic reticulum. J. Biol. Chem. 260: 522-530.

LIVAK K.J., SCHMITTGEN T.D. (2001) Analysis of relative gene expression data using realtime quantitative PCR and the 2(-Delta Delta C(T)) method. Methods 25(4): 402-408.

Loftus S.K., Morris J.A., Carstea E.D., Gu J.Z., Cummings C., Brown A., Ellison J., Ohno K., Rosenfeld M.A, Tagle D.A., Pentchev P.G., Pavan W.J. (1997) Murine model of Niemann-Pick $\mathrm{C}$ disease: mutation in a cholesterol homeostasis gene. Science 277(5323): 180-181.

LOMBARD J., MOREIRA D. (2011) Origins and early evolution of the mevalonate pathway of isoprenoid biosynthesis in the three domains of life. Mol. Boil. Evol. 28(1): 87-99. 
LUKÁCs GY., PAPP T., SOMOGYVÁRI F., CSERnETICS Á., NYILASI I., VÁGVÖlgYi Cs. (2009) Cloning of the Rhizomucor miehei 3-hydroxy-3-methylglutaryl-coenzyme A reductase gene and its heterologous expression in Mucor circinelloides. Ant. Leeuwenhoek 95(1): $55-64$.

LuM P.Y., EdWARdS S., Wright R. (1996) Molecular, functional and evolutionary characterization of the gene encoding HMG-CoA reductase in the fission yeast, Schizosaccharomyces pombe. Yeast 12: 1107-1124.

MADYASTHA K.M., SRIVATSAN J. (1987) Novel transformations of progesterone by a Mucor sp. Can. J. Microbiol. 33: 361-365.

Mehta B.J., Obraztsova I.N., CerdÁ-Olmedo E. (2003) Mutants and intersexual heterokaryons of Blakeslea trispora for production of $\boldsymbol{\beta}$-carotene and lycopene. Appl. Envir. Microbiol. 69 (7): 4043-4048.

MisAWA N. (2011) Pathway engineering for functional isoprenoids. Curr. Biotech. 22(5): $1-7$.

MisAWA N. AND SHIMADA H. (1997) Metabolic engineering for the production of carotenoids in non-carotenogenic bacteria and yeasts. J. Biotechnol. 59: 169-181.

MOORE K.B. AND OISHI K.K. (1993) Characterization of 3-hydroxy-3-methylglutaryl coenzyme A reductase activity during maize seed development, germination, and seedling emergence. Plant Phys.101: 485-491.

Mortensen A. (2006) Carotenoids and other pigments as natural colorants. Pure Appl. Chem. 78(8): 1477-1491.

MosquedA-CANO G., GUTIERREZ-CORONA J.F. (1995) Environmental and developmental regulation of carotenogenesis in the dimorphic fungus Mucor rouxii. Curr. Microbiol. 31(3): 141-145.

Naguib Y.M. (2000) Antioxidant activities of astaxanthin and related carotenoids. $J$. Agric. Food Chem. 48: 1150-1154.

Nagy G, Csernetics Á, Bencsik O, Szekeres A, VÁgvölgyi Cs, PapP T. (2012) Carotenoid composition of Mucorales fungi. Afr. J. Microbiol. Res. 6: 7265-7270.

NAVArro E., Ruiz-PÉreZ V.L., Torres-Martínez S. (2000) Overexpression of the crga gene abolishes light requirement for carotenoid biosynthesis in Mucor circinelloides. Eur. J. Biochem. 267: 800-807.

Nelson, A.J., DoERnER, P.W., ZHU, Q., LAMB, C.J. (1994) Isolation of a monocot 3hydroxy-3-methylglutaryl-coenzyme $A$ reductase gene that is elicitor-inducible. Plant Mol. Biol. 25: 401-412.

Nguyen A.D., McDonald J.G., Bruick R.K., DeBose-Boyd R.A. (2007) Hypoxia stimulates degradation of 3-hydroxy-3-methylglutaryl-coenzyme A reductase through 
accumulation of lanosterol and hypoxiainducible factor-mediated induction of insigs. $J$ Biol. Chem. 282:27436-27446.

NICKERSON W.J. (2006) Experimental control of morphogenesis in microorganisms. Ann. N. Y. Acad. Sci. 60: 50-57.

Nishino H., Murakosh M., II T., TaKemura M., Kuchide M., KanaZAWa M., Mou X.Y., Wada S., Masuda M., Ohsaka Y., Yogosawa S., Satomi Y., Jinno K. (2002) Carotenoids in cancer prevention. Cancer Metastasis Rev. 21: 257-264.

OLENDER E.H., SIMONI R.D. (1992) The intracellular targeting and membrane topology of 3-hydroxy-3-methylglutaryl coenzyme A reductase. J. Biol. Chem. 267:4223-4235.

Ong T.P., Heidor R., De Conti A., Dagli M.L., Moreno F.S. (2006) Farnesol and geraniol chemopreventive activities during the initial phases of hepatocarcinogenesis involve similar actions on cell proliferation and DNA damage, but distinct actions on apoptosis, plasma cholesterol and HMG-CoA reductase. Carcinogenesis 27(6): 11941203.

ORLOWSKY M. (1991) Mucor dimorphism. Microbiol. Rev. 55: 234-258.

ORLOWSKY M. (1994) Growth, differentiation and sexuality. Growth, Differentiation and Sexuality, The Mycota. Wessels J.G.H., Meinhardt F. (ed.), Springer Verlag, Vol. I, pp. 143.

ORSET S., YOUnG A.J. (1999) Low-temperature-induced synthesis of $\boldsymbol{\alpha}$-carotene in the microalga Dunaliella salina (chlorophyta). J. Phycology 35(3): 520-527.

OutTRup H., BOYCE C.O.L. (1990) Microbial proteinases and biotechnology. Microbial enzymes and biotechnology. Fogarty W.M., Kelly C.T. (ed.), Elsevier Applied Science Publ., London, pp. 227-254.

Pagni M., Ioannidis V., Cerutti L., Zahn-Zabal M., Jongeneel C.V., Hau J., Martin O., KUZNETSOV D., FALQUET L.(2007) MyHits: improvements to an interactive resource for analyzing protein sequences. Nucleic Acids Res. (Web Server issue): W433-437.

PAIVA S.A.R., RUSSEL, R.M. (1999) $\beta$-carotene and other carotenoids as antioxidants. $J$. Nutrition 5: 426-433.

Papp T., Nagy G., Csernetics Á., SzeKeres A., VÁgVÖlgyi Cs. (2009) Beta-carotene production by Mucoralean fungi. J. Eng. Ann. Fac. Eng. Huned. 7: 173-176.

PapP T., Nyilasi I., Csernetics Á., Galgóczy L., VÁgVÖlgyi Cs. (2008) Molecular studies on Zygomycetes fungi causing opportunistic infections. Rev. Med. Microbiol. 19(2): 39-46.

Papp T., Velayos A., BartóK T., Eslava A.P., VÁGVÖlgyi Cs., IturRiaga E.A. (2006) Heterologous expression of astaxanthin biosynthesis genes in Mucor circinelloides. Appl. Microbiol. Biotechnol. 69(5): 526-531. 
PapP T., Csernetics Á., NAgy G., Bencsik O., ItURriaga E.A., EslaVA A.P., VÁGVÖlgyi Cs. (2013) Canthaxanthin production with modified Mucor circinelloides strains. Appl. Microbiol. Biotechnol. 97: 4937-4950.

PoOt M., Zhang Y.Z., KRÄMER J.A., Wells K.S., Jones L.J., HANZEl D.K., LuGAdE A.G., SINGER V.L., HAUGLAND R.P. (1996) Analysis of mitochondrial morphology and function with novel fixable fluorescent stains. J. Histochem. Cytochem. 44(12): 1363-1372.

Powers S., Kataoka T., Fasano O., Goldfarb M., Strathern J., Broach J., Wigler M. (1984) Genes in S. cerevisiae encoding proteins with domains homologous to the mammalian ras proteins. Cell 36(3): 607-612.

QIAO J., Kontoyiannis D.P., Wan Z., Li R., LiU W. (2007) Antifungal activity of statins against Aspergillus species. Med. Mycol. 45: 589-593.

RAMSDAle M. (2006) Death-releated signalling pathway. Programmed cell death and apoptosis in Fungi. The Mycota. Brown A.J.P., Esser K. (ed.), Springer, Berlin, Heidelberg, Vol. XIII, pp. 113-138.

Ribes J.A., VANOver-SAMs C.L., BAKer D.J. (2000) Zygomycetes in Human Disease. Clin. Microbiol. Rev. 13: 236-301.

Rodriguez-Amaya D.B. (2001) A Guide to Carotenoid Analysis in Foods. Washington: OMNI Research, ILSI Press.

Roitelman J., Olender E. H., Bar-Nun S., Dunn W. A., Simoni R. D. (1992) Immunological evidence for eight spans in the membrane domain of 3-hydroxy-3methylglutaryl coenzyme A reductase: implications for enzyme degradation in the endoplasmic reticulum. J. Cell Biol. 117: 959-973.

Roze L.V., LiNZ J.E. (1998) Lovastatin triggers an apoptosis-like cell death process in the fungus Mucor racemosus. Fungal Genet. Biol 25(2): 119-133.

Ruiz-Albert J., Cerda-Olmedo E., Corrochano L.M. (2002) Genes for mevalonate biosynthesis in Phycomyces. Mol Genet Genomics. 266(5): 768-777.

Ruiz-Herrera J. (1993) Dimorphism in Mucor species. Dimorphic fungi in biology and medicine. van den Bossche H. Odds F.C., Herridge D. (ed.), Plenum Press, New York, pp. 257-265.

SAmbrook J., Fritsch E.F., Maniatis T. (1989) Molecular cloning: A laboratory manual. Cold Spring Harbor, New York.

SHARMA S.C. (2006) Implications of sterol structure for membrane lipid composition, fluidity and phospholipid asymmetry in Saccharomyces cerevisiae. FEMS Yeast Res. 6(7): 1047-1051.

Schilde C., Wöstemeyer J., Burmester A. (2001) Green fluorescent protein as a reporter for gene expression in the mucoralean fungus Absidia glauca. Arch. Microbiol. 175: $1-7$. 
SchimeK C., Kleppe K., SAlem A.-R., Voigt K., Burmester A.,Wöstemeyer J. (2003) Sexual reactions in Mortierellales are mediated by the trisporic acid system. Mycol. Res. 107: 736-747.

Seiler S., Plamann M. (2003) The genetic basis of cellular morphogenesis in the filamentous fungus Neurospora crassa. Mol. Biol. Cell. 14(11): 4352-4364.

SeOng K., Li L., Hou Z., Miles T., Kistler H.C., Xu J. (2006) Cryptic promoter activity in the coding region of the HMG-CoA reductase gene in Fusarium graminearum. Fungal Genet. Biol. 43: 34-41.

ShIMOMURA O., JoHnSON F.H., SAIGA Y. (1962) Extraction, purification and properties of aequorin, a bioluminescent protein from the luminous hydromedusan, Aequorea. $J$. Cell. Comp. Physiol. 59: 223-239.

Shirtliff M.A., Krom B.P., Mejiering R.A.M., Peters B.M., Zhu J., SchePer M.A., HARRIS M.L., JABRA-RIZK M.A. (2009) Farnesol-induced apoptosis in Candida albicans. Antimicrob. Agents Chemother. 53(6): 2392-2401.

Silvia F., TORRES-MARTínez S., GARRE V. (2006) Distinct white collar-1 genes control specific light responses in Mucor circinelloides. Mol. Microbiol. 61(4): 1023-1037.

SMith S.J., CROWLeY J.H., PARKS L.W. (1996) Transcriptional regulation by ergosterol in the yeast Saccharomyces cerevisiae. Mol. Cell Biol. 16: 5427-5432.

Som T., Kolaparthi V.S. (1994) Developmental decisions in Aspergillus nidulans are modulated by Ras activity. Mol. Cel.l Biol. 14(8): 5333-5348.

SteRmer B.A., BiAnChInI G.M., KORTH K. L. (1994) Regulation of HMG-CoA reductase activity in plants. J. Lipids Resch. 35: 1133-1140.

Todd B.L., Stewart E.V., Burg J.S., Hughes A.L., Espenshade P.J. (2006) Sterol regulatory element binding protein is a principal regulator of anaerobic gene expression in fission yeast. Mol. Cell Biol. 26: 2817-2831.

TsiEn R.Y. (1998) The green fluorescent protein. Annu. Rev. Biochem. 67: 509-544.

TUSNÁDy G.E., SiMON I. (2001) The HMMTOP transmembrane topology prediction server. Bioinformatics 17(9): 849-850.

VAINIO H. AND RAUTALAHTI M. (1998) An international evaluation of the cancer preventive potential of carotenoids. Cancer Epidemiol. Biomarkers Prev. 7: 725-728.

VAN HEESWIJK R., RONCERO M.I.G. (1984) High frequency transformation of Mucor with recombinant plasmid DNA. Carlsberg Res. Commun. 49: 691-702.

VAn LaAR T.A., LiN Y.H., Miller C.L., Karna S.L.R., Chambers J.P., Seshu J. (2012) Effect of levels of acetate on the mevalonate pathway of Borrelia burgdorferi. PLOS ONE 7:e38171. 
VAUPOTIČ T. AND Plemenitaŝ A. (2007) Osmoadaptation-depentent activity of microsomal HMG-CoA reductase in the extremely halotolerant black yeast Horteae werneckii is regulated by ubiquitination. FEBS Letters 581: 3391-3395.

Vaupotič T., Veranic P., Petrovič U., Gunde-Cimerman N., Plemenitaŝ A. (2008) HMG-CoA reductase is regulated by environmental salinity and its activity is essential for halotolerance in halophilic fungi. Stud.Mycol. 61: 61-66.

Velayos A., LóPez-Matas M.A., Ruiz-Hidalgo M.J., Eslava A.P. (1997) Complementation analysis of carotenogenic mutants of Mucor circinelloides. Fungal Genet. Biol. 22: 19-27.

Velayos A., Blasco J.L., Alvarez M.I., Iturriaga E.A., Eslava A.P. (2000a) Blue-light regulation of phytoene dehydrogenase (carB) gene expression in Mucor circinelloides. Planta 210: 938-946.

Velayos A., Eslava A.P., ItURriaga E.A. (2000b) A bifunctional enzyme with lycopene cyclase and phytoene synthase activities is encoded by the carRP gene of Mucor circinelloides. Eur. J. Biochem. 267: 1-12.

VerwaAl R., Wang J., Meijnen J-P., Visser H., SANDMAnN G., VAN DEn Berg J.A., VAN OOYEN A.J.J (2007) High-Level production of beta-carotene in Saccharomyces cerevisiae by successive transformation with carotogenic genes from Xanthophyllomyces dendrorhous. Appl Environ. Microbiol. 73(13): 4342-4350.

VIK A., RINE J. (2001) Upc2p and Ecm22p, dual regulators of sterol biosynthesis in Saccharomyces cereviaise. Mol. Cell Biol. 21(19): 6395-405.

VOJTEK A.B., CHANNING J.D. (1998) Increasing complexity of the Ras signaling pathway. J. Biol. Chem. 273: 19925-19928.

Walsh T.J., Groll A., Hiemenz J., Fleming R., Roilides E., ANAissie E. (2004) Infections due to emerging and uncommon medically important fungal pathogens. Clin. Microbiol. Infect. 10(S1): 48-66.

WARD O. (1995) Microbial production of long-chain PUFAs. Inform. 6: 683-688.

YAmAda H., Shimizu S., SHINMEN Y., AKImOto K., KAWASHIMA H., JAREONKITMONGKOL S. (1992) Production of dihomogamma-linolenic acid, arachidonic acid, and eicosapentaenoic acid by filamentous fungi. Industrial applications of single cell oils. Champaign I.L. (ed.), American Oil Chemists Society Press (AOCS), USA Illinois, pp. 118138.

YAN G-L., WEN K-R., DUAN C-Q. (2012) Enhancement of $\beta$-carotene production by over expression of HMG-CoA reductase coupled with addition of ergosterol biosynthesis inhibitors in recombinant Saccharomyces cerevisiae. Curr. Microbiol. 64(2): 159-163. 


\section{KöSZÖNETNYILVÁNÍTÁS}

Elsősorban köszönetet szeretnék mondani Prof. Dr. Vágvölgyi Csabának, a Szegedi Tudományegyetem, Természettudományi és Informatikai Kar, Mikrobiológiai Tanszék vezetőjének, hogy a tanszéken munkámat lehetővé tette, figyelemmel kísérte és támogatta.

Hálával tartozom témavezetőmnek, Dr. Papp Tamásnak, áldozatos munkájáért, aki munkámat mindvégig támogatta, megosztotta velem széleskörü elméleti és gyakorlati szaktudását és megadott minden segítséget munkám sikeres elvégzéséhez.

Külön köszönettel tartozom Dr. Nyilasi Ildikónak, Dr. Csernetics Árpádnak, Dr. Linka Beátának, Dr. Galgóczy Lászlónak a sok hasznos tanácsért, ötletadó beszélgetésért és elméleti valamint gyakorlati segítségnyújtásért.

Köszönöm minden közvetlen munkatársamnak, Dr. Krizsán Krisztinának, Petkovits Tamásnak, Czikora Máténak, Tóth Eszternek, Farkas Anitának, Páll Orsolyának a laborban nyújtott nélkülözhetetlen segítségüket, barátságukat.

Köszönettel tartozom Ferhan Ayaydinnak, hogy lehetővé tette és segítette a konfokális mikroszkóppal történő vizsgálatokat az SZBK Mikroszkópos sejtanalízis laborban. Köszönöm Dr. Szekeres Andrásnak és Bencsik Ottónak a HPLC kísérletek során nyújtott segítségüket. Meg szeretném köszönni Dr. Victoriano Garre-nak a lehetőséget, hogy a laborjában elsajátíthattam a Northern-hibridizációs technikát.

Köszönetemet fejezem ki Lele Máriának, Deákné Kulcsár Melindának, valamint Farkas Elvirának a munkám során nyújtott technikai segítségért, valamint Dr. Palágyi Andrásnénak, Kreisch Istvánnénak, Szőnyi Jánosnénak és Lengyel Boglárkának, hogy a munkámmal kapcsolatos hivatalos ügyeket intézték. Köszönet illeti továbbá a Mikrobiológiai Tanszék minden munkatársát és dolgozóját.

Külön köszönet illeti Borsos Barbarát mind elméleti, mind pedig a gyakorlati segítségekért, ötletadó beszélgetésekért és nem utolsó sorban a barátságáért.

Hálával tartozom a páromnak, Dr. Nagy Adriennnek, aki mindvégig mellettem állt, támogatott, és szeretetével erősítette a munkámat.

És végezetül, de nem utolsó sorban hálával és köszönettel tartozom szüleimnek, akik egész életem folyamán önzetlenül, feltétel nélkül támogattak, és szeretetükkel mindvégig biztos hátteret nyújtottak. 


\section{Melléklet}

1. melléklet. A M. circinelloides HMG-KoA reduktáz génjeinek genomi DNS szekvenciái az intronokkal, valamint a génekről átíródó feltételezett fehérjék aminosav sorrendje. A sárga háttérrel jelzett nukleotidok mutatják az intronszekvenciákat.

\section{A hmgRI gén teljes szekvenciája és az általa kódolt feltételezett fehérje aminosavsorrendje}

Atg ATC AAT CTG CTG TCC TAT AAA TCC ATC ACt GGC TTC ATG AAC CGG CTG GTG $\begin{array}{llllllllllllllllllllll}M & I & N & \text { L } & \text { I } & S & Y & K & S & I & T & G & F & M & N & R & \text { L } & \text { V }\end{array}$ CTC AAG ACA TCT AAA GTA TCC GCC TTG AAC CCT ATA GAA ACG ATG GTA GCA AGT $\begin{array}{llllllllllllllllll}\mathrm{L} & \mathrm{K} & \mathrm{T} & \mathrm{S} & \mathrm{K} & \mathrm{V} & \mathrm{S} & \mathrm{A} & \mathrm{L} & \mathrm{N} & \mathrm{P} & \mathrm{I} & \mathrm{E} & \mathrm{T} & \mathrm{M} & \mathrm{V} & \mathrm{A} & \mathrm{S}\end{array}$ CTG AtT tTg GGG TCT GTG ACC TAC GTC TAC CTG TTC AAT CTA GCG AAA TCG TCA $\begin{array}{lllllllllllllllllll}I & I & L & G & S & V & T & Y & V & Y & \text { L } & F & N & \text { L } & A & K & S & S\end{array}$ GAG ATA CTG TCC ACA GCC AGC ATC TAC GAC ACA TCG TTT GTG TCC ACC ATC CTG $\begin{array}{lllllllllllllllllllllllllll}E & I & L & S & T & A & S & I & Y & D & T & S & F & V & S & T & I & \text { L }\end{array}$ TAC GCT TCT CCA AAC GAC ATT TCG TTT TCG CCA TTA AAg CAA GAT CCT CCA TTA $\begin{array}{llllllllllllllllllllllll}Y & A & S & P & N & D & I & S & F & S & P & L & K & O & D & P & P & \text { L }\end{array}$ CCA GCA GTA TCG ATA TCG CGT ATT GAA CTC AAg CAg ATC GCC ATC GCC TTG ACG $\begin{array}{lllllllllllllllllll}P & A & V & S & I & S & R & I & E & L & K & Q & I & A & I & A & L & T\end{array}$ GAT CCC GCA CAT CAG CAC AAC ATG GAT GCC ATC CAG CGT TTT CGC AAT CAT GTT $\begin{array}{lllllllllllllllllll}D & P & A & H & Q & H & N & M & D & A & I & Q & R & F & R & N & H & \text { V }\end{array}$ GAA TCC ACT CCA GTC GAT TTC TCC GAT TTA GAg CAT CAA GAA AAg GGG CTA ATG

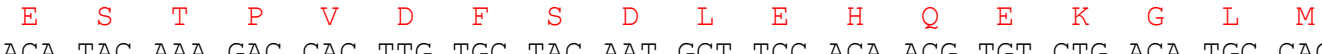

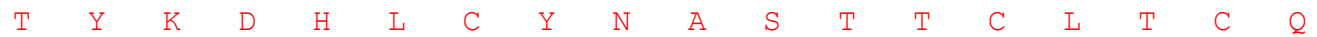
CCA TTC AAT CGA GAC AAC AGT GCG ATt CTG TCG TAT GTG TTT GAT CTG AgC AAT $\begin{array}{llllllllllllllllll}\mathrm{P} & \mathrm{F} & \mathrm{N} & \mathrm{R} & \mathrm{D} & \mathrm{N} & \mathrm{S} & \mathrm{A} & \mathrm{I} & \mathrm{L} & \mathrm{S} & \mathrm{Y} & \mathrm{V} & \mathrm{F} & \mathrm{D} & \mathrm{L} & \mathrm{S} & \mathrm{N}\end{array}$ GAT CAG CGT ATT AAG GCC TCT CAT TTA TGG GAC CAA AAg GTC ATG TCA TCT TCC $\begin{array}{llllllllllllllllllllll}\mathrm{D} & \mathrm{Q} & \mathrm{R} & \mathrm{I} & \mathrm{K} & \mathrm{A} & \mathrm{S} & \mathrm{H} & \mathrm{L} & \mathrm{W} & \mathrm{D} & \mathrm{Q} & \mathrm{K} & \mathrm{V} & \mathrm{M} & \mathrm{S} & \mathrm{S} & \mathrm{S}\end{array}$ GTG GAC AGA CTC ATT CCT ATG GCG ACA CAA CAT CAA TAC AAC GAG AGG AGT ATC

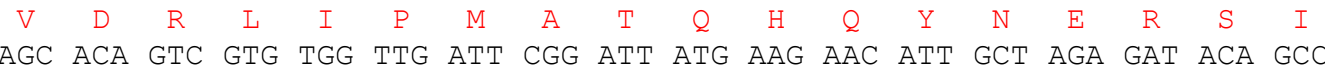
$\begin{array}{lllllllllllllllllll}S & T & V & V & W & \mathrm{~L} & \mathrm{I} & \mathrm{R} & \mathrm{I} & \mathrm{M} & \mathrm{K} & \mathrm{N} & \mathrm{I} & \mathrm{A} & \mathrm{R} & \mathrm{D} & \mathrm{T} & \mathrm{A}\end{array}$ GTG CGC ATG AAT gtaagaaacggacatgctcatcagaatgcaacatgtagctaatccacccaatag $\begin{array}{llll}\mathrm{V} & \mathrm{R} & \mathrm{M} & \mathrm{N}\end{array}$ AGT GCT TCC AAg ATG GAT GTG ATT GTA GTA ACA GCA GGC TAC ATt ATG ATG GCC

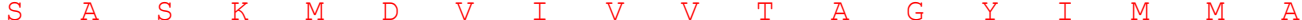
tTC ACC tTC tTA tCA CTG tAt ATC AGA ATG CAT AAA tTG gGA tCA AAA tAT ACt

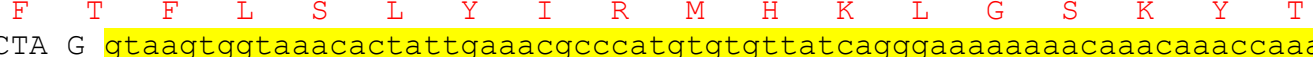
T ttaattaacctttag CA ACC ACT ATC TTC ATG TCG GGT TTC TTT TCA TTT ATG CTC TCT CTG GCC ACC GTG TAT AAA TTG GGC GCA CCT GTC AGT CCT GTT TTA TTG $\begin{array}{lllllllllllllllllllll}\mathrm{L} & \mathrm{S} & \mathrm{L} & \mathrm{A} & \mathrm{T} & \mathrm{V} & \mathrm{Y} & \mathrm{K} & \mathrm{L} & \mathrm{G} & \mathrm{A} & \mathrm{P} & \mathrm{V} & \mathrm{S} & \mathrm{P} & \mathrm{V} & \mathrm{L} & \mathrm{L}\end{array}$ AG gtt tgtacggtttattatggagcatgtcgtatacatggggcttctctttttaacagaaaaaaaacc tcatcag T GAA GCA ACG CCG TTT TTG GTA GTG ACG ATA GGA TTC GAA CGG CCC

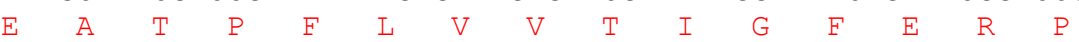
tAC AAA CTC ACC AAA TGC ATA TTC GAg CAA GAA AGC AAC AAT ACC GAC AAC AGT $\begin{array}{llllllllllllllllllllll}Y & K & L & T & K & C & I & F & E & Q & E & S & N & N & T & D & N & S\end{array}$ AAT GTG CTG CAA ATC ATC TCA CGC TCT GTG GAA ATG ATG GCA CCA ACC TTG ATt

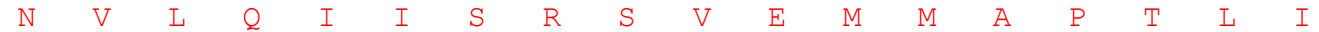
CGA GAT GGA CTA TTG GAg ATt GTG GTA TTC ATA CTG GGC GCC AAA TCA ACA TTG $\begin{array}{lllllllllllllllll}R & D & G & L & L & E & I & V & V & F & I & L & G & A & K & S & T\end{array}$ CCT GGA TTG CGC GAG TTC TGT CTG ATG AGT GCA tTT tTG ATT GCT tAC GAC ATG 
Atg tTG ATG tTT ACT TGG TAC AtT TCA GTC tTG tCA tTA AAg tTG gAg gtaacag $\begin{array}{llllllllllllllll}M & \mathrm{~L} & \mathrm{M} & \mathrm{F} & \mathrm{T} & \mathrm{W} & \mathrm{Y} & \mathrm{I} & \mathrm{S} & \mathrm{V} & \mathrm{L} & \mathrm{S} & \mathrm{L} & \mathrm{K} & \mathrm{L} & \mathrm{E}\end{array}$

GAG ACA ACC TCG ACT AGT ACC ACG ACG ACG ACA TCT ATT CTT GAA ACA GCA GCA $\begin{array}{llllllllllllllllll}\mathrm{L} & \mathrm{P} & \mathrm{P} & \mathrm{V} & \mathrm{K} & \mathrm{S} & \mathrm{L} & \mathrm{L} & \mathrm{A} & \mathrm{E} & \mathrm{I} & \mathrm{Y} & \mathrm{N} & \mathrm{T} & \mathrm{Y} & \mathrm{A} & \mathrm{V} & \mathrm{Y}\end{array}$ GCA CAG GAT CCT GTC ATC AGC AAA TGG GTG GTC GCT ATt TTG ATG GTG tCC ATC $\begin{array}{llllllllllllllllll}A & Q & D & P & V & I & S & K & W & V & V & A & I & L & M & V & S & I\end{array}$

CTG TTT GAG ATT GCC AAA TAC AAT CGA CAA ACA GCG CAA GTC AAT GGT GCC ACC ACG GTG TTG ATC TCG GAC GGT ATG ACG CGC GGC CCT TGT $\begin{array}{llllllllllllllllll}V & N & G & A & T & T & V & L & I & S & D & G & M & T & R & G & P & C\end{array}$ GTC GAg TTT CCC AAC ATC ATt GAT GCT GGC CTA TGC AAg CGC TGG CTG GAt CAg $\begin{array}{llllllllllllllllll}V & E & F & P & N & I & I & D & A & G & L & C & K & R & W & L & D & Q\end{array}$ GAG GAg GGA TTT GAG ATT GTA GCA GAG GCT TTC AAC AGC ACA TCC AGg TTT GCT CGg GTG CGT AAA ATG CAG GTA GCA ATG GCC GGC AAg CTG CTG TAC ATt CGA tTC $\begin{array}{lllllllllllllllllll}R & V & R & K & M & Q & V & A & M & A & G & K & L & L & Y & I & R & F\end{array}$ TCT ACG ACA ACA GGC GAC GCA ATG GGC ATG AAC ATG ATT TCC AAA GGC TGC GAA 
ATA GGA TCT GCC ATG GCT GGG TCG GTG GGT GGA TTC AAT GCA CAT GCA GCC AAT

$\begin{array}{llllllllllllllllll}I & G & S & A & M & A & G & S & V & G & G & F & N & A & H & A & A & N\end{array}$

ATC TTG ACG GCC ATG TAC ATt GCA GTA GGA CAG GAT CCG GCG CAG AAT GTA GAG

AGC AGC AAt TGT ATC ACC CTG AtG AAg TCG GTC AAC AAT GGA TCG GCG CTG CAC

$\begin{array}{llllllllllllllllllllll}S & S & N & C & I & T & L & M & K & S & V & N & N & G & S & A & L & H\end{array}$

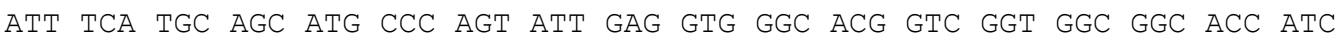

$\begin{array}{llllllllllllllllll}I & S & C & S & M & P & S & I & E & V & G & T & V & G & G & G & T & I\end{array}$

TTG CCC CCG CAA CAA GCC ATG CTG GAC ATG CTT GGT GTG CGA GGT CCT CAT CCA

3413

1030

$\begin{array}{llllllllllllllllll}\mathrm{L} & \mathrm{P} & \mathrm{P} & \mathrm{O} & \mathrm{Q} & \mathrm{A} & \mathrm{M} & \mathrm{L} & \mathrm{D} & \mathrm{M} & \mathrm{L} & \mathrm{G} & \mathrm{V} & \mathrm{R} & \mathrm{G} & \mathrm{P} & \mathrm{H} & \mathrm{P}\end{array}$

3467

ACA CAT CCA GGT AAA AAT GCT CAG AAA CTG GCG AGG ATC ATC TGC GCT GCT GTC

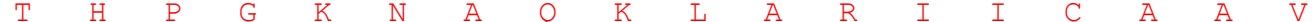

3521

ATG GCG GGT GAG CTT TCG TTA TGT GCG GCT CTG GCA GCA GgG CAT TTG GTT AAG

1066

3575

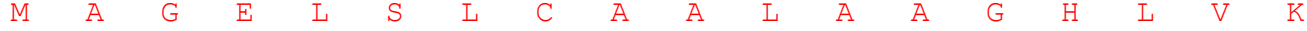

$\begin{array}{llllllllllllllllll}\mathrm{A} & \mathrm{H} & \mathrm{M} & \mathrm{Q} & \mathrm{H} & \mathrm{N} & \mathrm{R} & \mathrm{V} & \mathrm{S} & \mathrm{T} & \mathrm{A} & \mathrm{A} & \mathrm{A} & \mathrm{A} & \mathrm{A} & \mathrm{V} & \mathrm{P} & \mathrm{A}\end{array}$

GTC GAA AAC GAC ATT CAC AAG AAA AAG GCA CTC AAG ACT CCC GCT TCA ACA CCG

1102

3683

$\begin{array}{llllllllllllllllll}V & \mathrm{E} & \mathrm{N} & \mathrm{D} & \mathrm{I} & \mathrm{H} & \mathrm{K} & \mathrm{K} & \mathrm{K} & \mathrm{A} & \mathrm{L} & \mathrm{K} & \mathrm{T} & \mathrm{P} & \mathrm{A} & \mathrm{S} & \mathrm{T} & \mathrm{P}\end{array}$

1120

AgA tCT tTG CAG TCG AgG CAg Agt ACA GTG CCT GTA ACG gGA AAt tgC ATC tTA

TAG

\section{A hmgR2 gén teljes szekvenciája és az általa kódolt feltételezett fehérje aminosavsorrendje}

ATG TTG AAA AAC GTC AAA AAA GAT AAC CCG TTC CGA TAT TTG GCT CAT GTA TCC

$\begin{array}{llllllllllllllllll}M & \mathrm{~L} & \mathrm{~K} & \mathrm{~N} & \mathrm{~V} & \mathrm{~K} & \mathrm{~K} & \mathrm{D} & \mathrm{N} & \mathrm{P} & \mathrm{F} & \mathrm{R} & \mathrm{Y} & \mathrm{L} & \mathrm{A} & \mathrm{H} & \mathrm{V} & \mathrm{S}\end{array}$ GCG CGA AAT CCA TTT GAA ATG ATG GTC GCC GTA TTC ATC GCA TGC TCA tTC TCC TAT CTA TAC CTC ACA AAC ACC TAC AAC AAA GGG TTG CAT GAC ATG ACA TCC ACT

$\begin{array}{llllllllllllllllll}Y & \mathrm{~L} & \mathrm{Y} & \mathrm{L} & \mathrm{T} & \mathrm{N} & \mathrm{T} & \mathrm{Y} & \mathrm{N} & \mathrm{K} & \mathrm{G} & \mathrm{L} & \mathrm{H} & \mathrm{D} & \mathrm{M} & \mathrm{T} & \mathrm{S} & \mathrm{T}\end{array}$

CAC CCC ATT GCC TAT TAC CAT AGC AAC CAG TCA ACG CAT CAC CAT GGA AAC AGC

$\begin{array}{llllllllllllllllll}\mathrm{H} & \mathrm{P} & \mathrm{I} & \mathrm{A} & \mathrm{Y} & \mathrm{Y} & \mathrm{H} & \mathrm{S} & \mathrm{N} & \mathrm{Q} & \mathrm{S} & \mathrm{T} & \mathrm{H} & \mathrm{H} & \mathrm{H} & \mathrm{G} & \mathrm{N} & \mathrm{S}\end{array}$

AAT GAC GAC AAC AAG AGT GTC ATT CTA AAg CAG CTG GTA TTG CAC CAC CGT CAG

$\begin{array}{llllllllllllllllllllll}\mathrm{N} & \mathrm{D} & \mathrm{D} & \mathrm{N} & \mathrm{K} & \mathrm{S} & \mathrm{V} & \mathrm{I} & \mathrm{L} & \mathrm{K} & \mathrm{Q} & \mathrm{L} & \mathrm{V} & \mathrm{L} & \mathrm{H} & \mathrm{H} & \mathrm{R} & \mathrm{Q}\end{array}$

GAC ATG ATG ACC AAA GAG GCC CTC CAA TCT GTG CTC TCA TTC CAA GAA TCA CTG

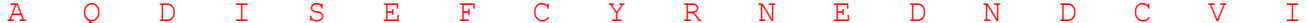


TAC ACG AAA TCG ATT TTA AGC AAC ACA AAC AAT AAC AAC GAC AAC TCC GTT TTC

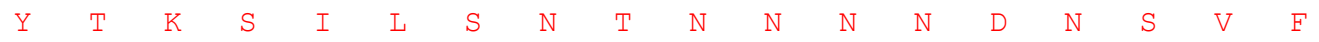
ATG ATG CTC GCT TGG GAT TGT TTC ACT GAA ATt ACT ATC TTT TGT CTT GGT GCC $\begin{array}{llllllllllllllllll}M & M & L & A & W & D & C & F & T & E & I & T & I & F & C & L & G & A\end{array}$

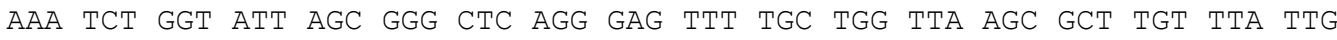
$\begin{array}{llllllllllllllllll}K & S & G & I & S & G & L & R & E & F & C & W & L & S & A & C & L & L\end{array}$ GCG TTT GAT TTT GTG CTC CTT TGC ACT TGG TAC ACA GCC ATA TTG GCT TTA AAC

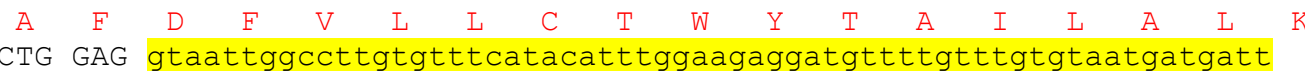
L $\quad$ E tatattgtgttattcttag CTG AAT CGA TTC AAT ACG GCA GAC GAG ATC AAG CAC CAG $\begin{array}{llllllllllllllll}I & N & R & F & N & T & A & D & E & I & K & H & Q\end{array}$ CCA AGC AAC TAC AGC AGC GCA TCT GTT TGG CAT TGG ATC CTG GAA AAg ATG AAG

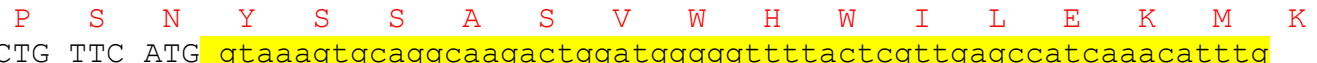
L $\quad$ F $\quad$ M aaaatttttcttctctattgattacagtttaactaaccgcaccaattacaaatttggcttcgttag ATT GTA GGC TTT ATA GGA ATG CAT ATC TTT AAA GTT TGC TCC ACT TTC CAA CAA

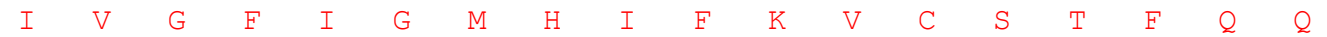
GAA CCT CTT TCA TTC ACT ACT GTA GAT ACT AGT CAG CCA ACC GTC GCC TTT GTA $\begin{array}{llllllllllllllllllllllllllllllll}E & P & L & S & F & T & T & V & D & T & S & Q & P & T & V & A & F & V\end{array}$ TTA TCT GAA CTA CTG GAT AAG CAA CCA CTC GTC AAA GTA TTT CCA AAC CAG TAT $\begin{array}{lllllllllllllllllllllllllllllll}L & S & E & L & L & D & K & Q & P & L & V & K & V & F & P & N & Q & Y\end{array}$ TTC TAT GCT GTA ATA TCA CCA TCT GCT ACT TGT TTT TCC ACA TCC TCT CTA TTT $\begin{array}{llllllllllllllllll}F & Y & A & V & I & S & P & S & A & T & C & F & S & T & S & S & L & F\end{array}$ CAA CAA TAT CAA CTT TAT TAC ATT ATG ATC AAg CCC TTT GAg AGC CTA TTC GAC

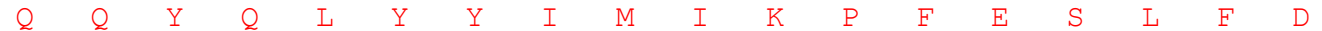
ATT TAC GCT GTC TAT ATT CAA CAT CCC GTT ATA TCC AAA TGG CTG ACT ATC GCT $\begin{array}{lllllllllllllllll}I & Y & A & V & Y & I & O & H & P & V & I & S & K & W & L & T & I\end{array}$ CTC TGT GTC TCC CTA TTC CTC AAT ACC TAT CTG TTC AAT GTA GCA AAg CAG CAA

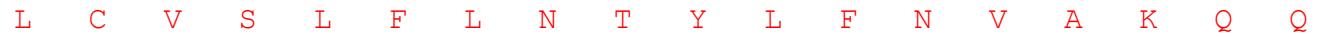
CCA AAA GTA GTG GTA CAA AAA GTT ATT GAA AAG GTC CAA GTA CCT GTG CAG GTT

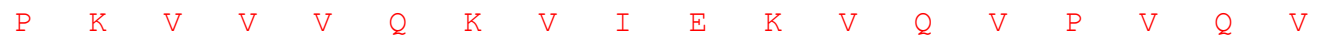
CCA GCT GCC AAG AAG GAA AAg AAg GTT GCT CCC GCA TCT CCA TCC GTA GCC ATG $\begin{array}{llllllllllllllllll}\mathrm{P} & \mathrm{A} & \mathrm{A} & \mathrm{K} & \mathrm{K} & \mathrm{E} & \mathrm{K} & \mathrm{K} & \mathrm{V} & \mathrm{A} & \mathrm{P} & \mathrm{A} & \mathrm{S} & \mathrm{P} & \mathrm{S} & \mathrm{V} & \mathrm{A} & \mathrm{M}\end{array}$ GCA ACC AAA AAG TCG CAT CAA CAT CAT CAC CAT CAT CAC CAA CAA CAG CAT CAC $\begin{array}{llllllllllllllllllllllllll}A & \mathrm{~T} & \mathrm{~K} & \mathrm{~K} & \mathrm{~S} & \mathrm{H} & \mathrm{Q} & \mathrm{H} & \mathrm{H} & \mathrm{H} & \mathrm{H} & \mathrm{H} & \mathrm{H} & \mathrm{Q} & \mathrm{Q} & \mathrm{Q} & \mathrm{H} & \mathrm{H}\end{array}$ CGC TCT GAT ATC GTA CGC CCC TTG GAT GAA GTG TTC AGT TTA ATC GGT ACG CCT $\begin{array}{llllllllllllllllll}R & S & D & I & V & R & P & L & D & E & V & F & S & L & I & G & T & P\end{array}$ GAg GTA TTG ACA GAC GAA GAG ATC ATC TCT GTT GTT CAG AGT GGA AAg ATG GCT

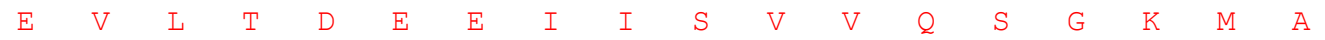
GCC TAC GCG CTT GAA AAG GTA CTG GGT GAT TTT GAA CGC GCT GTG CAT ATT CGC $\begin{array}{llllllllllllllllllllllllllllll}A & Y & A & L & E & K & V & L & G & D & F & E & R & A & V & H & I & R\end{array}$ AGA GCT TTG GTT TCG CGT GAT TCC ATC ACC AAg TCG CTG GAg GGT AGC TTG CTT $\begin{array}{llllllllllllllllll}R & A & L & V & S & R & D & S & I & T & K & S & L & E & G & S & L & L\end{array}$ CCT GTC AAG AAC TAC CAC TAT GAC AAG GTG ATG GGT GCA TGT TGT GAA AAC GTG

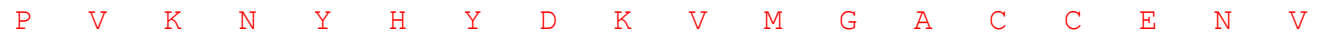
ATT GGT TAT ATG CCT ATT CCA GTT GGT GTA GCA G gtaaacacatatatacaaacaaat $\begin{array}{lllllllllll}\text { I G } & \text { Y } & \text { M } & \text { P } & \text { I } & \text { P } & V & G & \text { V } & \text { A } & \\ \text { gcaaacatgacaagtgtattgacagtggcacag } & \text { GT } & \text { CCA } & \text { TTG AAC ATT GAC GGC GAT CTG }\end{array}$

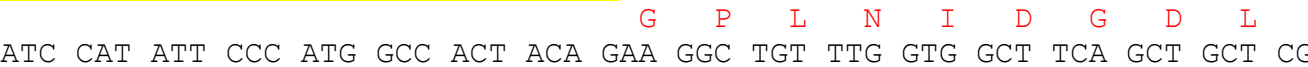

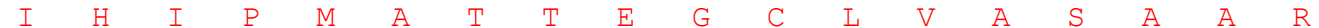
GGC TGC AAG GCC ATC AAT GCT GGT GGA GGA GCT ACT ACT ATT GTT ACT GCA GAT

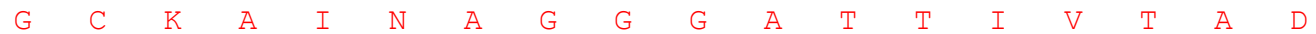
GGC ATG ACC CGT GGA CCC TGT GTT GAA TTC CCA GAC ATT CTC CGT GCA GCC GAT $\begin{array}{llllllllllllllllllllllll}G & M & T & R & G & P & C & V & E & F & P & D & I & L & R & A & A & D\end{array}$ TGT AAG CGT TGG ATT GAA CAA GAA GGA GAA AAg GTA GTG ACC GAG GCA TTC AAC $\begin{array}{llllllllllllllllll}C & K & R & W & I & E & Q & E & G & E & K & V & V & T & E & A & F & N\end{array}$ TCG ACC TCT CGT TTT GCT CGT GTT CGC AAg CTG AAg GTt GCT CTT GCT GGC CGC $\begin{array}{llllllllllllllllll}S & T & S & R & F & A & R & V & R & K & L & K & V & A & L & A & G & R\end{array}$ TTA ATG TAC ATT CGA TTC TCT ACT ACG ACT GGC GAT GCT ATg GGC ATG AAT ATG $\begin{array}{llllllllllllllllll}L & M & Y & I & R & F & S & T & T & T & G & D & A & M & G & M & N & M\end{array}$ AtT tCA AAg GGC TGT GAA AAg GCA CTG TCC AAg ATt GCA GAg AgA tAt CCC GAt $\begin{array}{llllllllllllllllll}I & S & K & G & C & E & K & A & L & S & K & I & A & E & R & Y & P & D\end{array}$ ATG CAA ATC ATT TCT CTT TCT GGC AAC TAC TGT ACC GAC AAG AAG CCT GCT GCT

1102 330

1156 348

1210 366

1264

384

1330

386

1388

392

1442

417

1507

420

1575

1629

438

1683

456

1737

474

1791

492

1845

510

1899

528

1953

546

2007

564

2061

582

2115

600

2169

618

2223

636

2277

654

2331

672

2385

670

2444

701

2503

703

2557

728

2611

746

2665

764

2719

782

2773

800

2827

818

2881

836

2935

854 
ATt AAT TGG ATt GAG GGT CGT GGC AAg TCG GTT GTC GCT GAG GCT GTT ATT CCC

$\begin{array}{llllllllllllllllllllll}I & N & W & I & E & G & R & G & K & S & V & V & A & E & A & V & I & P\end{array}$

GGT GCT GTC GTT GAG AAG GTC CTC AAA ACC ACT GTC GCT GCT CTT GTG GAA TTG

AAC GTC TCC AAG AAT TTG GTC GGT tCt GCC AtG GCt GGC TCT GTG GGT GGA tTC

$\begin{array}{llllllllllllllllllllll}N & V & S & K & N & \text { L } & V & G & S & A & M & A & G & S & V & G & G & F\end{array}$

3097

908

AAT GCA CAC GCT GCT AAC ATT TTG ACC GCC ATC TAC CTC GCT ACA GGC CAA GAT

3151

$\begin{array}{llllllllllllllllll}\mathrm{N} & \mathrm{A} & \mathrm{H} & \mathrm{A} & \mathrm{A} & \mathrm{N} & \mathrm{I} & \mathrm{L} & \mathrm{T} & \mathrm{A} & \mathrm{I} & \mathrm{Y} & \mathrm{L} & \mathrm{A} & \mathrm{T} & \mathrm{G} & \mathrm{O} & \mathrm{D}\end{array}$

CCC GCC CAG AAT GTC GAA AGC TCC ATG TGT ATT ACT CTG ATG AAG GCT GTC AAC

AAT GAC AAG GAT CTC AAC ATC TCT TGT ACT ATG CCC TGT ATC GAA GTT GGC ACT

ATT GGT GGT GGT ACT ATC TTA CCC CCT CAA CAA GCC ATG CTG GAT TTC CTT GGT

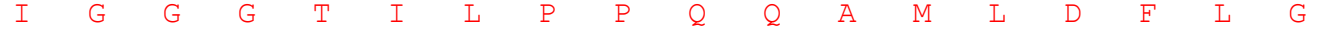

GTG CGT GGC CCT CAT CCC ACT GAA CCC GGA GCC AAT GCT CGT CGC CTT GCT CGT

$\begin{array}{cccccccccccccccccc}V & R & G & P & H & P & T & E & P & G & A & N & A & R & R & L & A & R \\ \text { ATC } & \text { ATC } & \text { TGT } & \text { GCC } & \text { TCT } & \text { GTG } & \text { ATG } & \text { GCT } & \text { GGT } & \text { GAG } & \text { CTC } & \text { TCT } & \text { CTC } & \text { TGT } & \text { GCT } & \text { GCT } & \text { TTG } & \text { GCC }\end{array}$

$\begin{array}{llllllllllllllllll}I & I & C & A & S & V & M & A & G & E & L & S & L & C & A & A & L & A\end{array}$ GCT GGA CAT TTG GTC CAG GCC CAC ATG GCT CAC AAC CGT AAC ACT GCT GCT GCT GCC GCT GCT CCT GCC GCC GCT GCT CCC TCT ATT GCC GCT TCT GTC ATT CAG GCT

\section{A hmgR3 gén teljes szekvenciája és az általa kódolt feltételezett fehérje aminosavsorrendje}

ATG GCG TCT GCT CTC CCC CAT CAT TCT GGA ACC AGC GCC TTT CGG TCC ATT TCC $\begin{array}{llllllllllllllllll}M & A & S & A & \text { L } & P & H & H & S & G & T & S & A & F & R & S & I & S\end{array}$ AgC GTC TTT GGC AAA GGC ATC CAC CGT GCC GCC AAG CTC TCG TCT CGC AAC CCC $\begin{array}{llllllllllllllllllllllllllll}S & V & F & G & K & G & I & H & R & A & A & K & L & S & S & R & N & P\end{array}$ ATC GAg ATG ATt GCG GGC ATC CTG ATt CTG TCG TCC TTT AgC tAC tTT TAC CTG

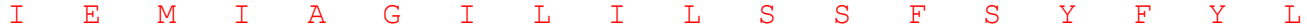


CGC TAC ACA CTC GCC ACG GCC GTC GTG GTC AAC GGC TTC TTT tCA tTC ATG tTT $\begin{array}{lllllllllllllllllllllll}R & Y & T & L & A & T & A & V & V & V & N & G & F & F & S & F & M & F\end{array}$ GCC CTG TTG ACT GTC AAT GCG CTG GGC GTC GAT GTC TAC CCC GTT GTA CTG GC $\begin{array}{cccccccccccccccccc}\text { A L } & \text { L } & \text { T } & \text { V } & \text { N } & \text { A } & \text { L } & \text { G } & \text { V } & \text { D } & \text { V } & \text { Y } & \text { P } & \text { V } & \text { V } & \text { L } & \text { A } \\ \text { gtgagtattatcatcgtgaagcatgttgttccttctctcagtctaaccaacccttggcatcatag } & \text { T } & \text { GAG }\end{array}$ GCC ATT CCC TTT TTG GCG GTT ACC ATT GGT TTT GAG CGT CAT TTC AAG CTT ACC $\begin{array}{llllllllllllllllll}A & I & P & F & L & A & V & T & I & G & F & E & R & H & F & K & L & T\end{array}$ AAA AGA GTG TTT GAg tTC AGC AAg GAg ACC CCA TTG ACC AAg CAg GAg AtC AGA $\begin{array}{lllllllllllllllllllllll}K & R & V & F & E & F & S & K & E & T & P & L & T & K & Q & E & I & R\end{array}$ AAg ACC ATT GTG CGT GCA GTC GAT TCC GTT GCC TTG CCC ATC GCC AGA GAC TGC $\begin{array}{llllllllllllllllll}K & T & I & V & R & A & V & D & S & V & A & L & P & I & A & R & D & C\end{array}$ ATC ATG GAA ATC ACG GTG CTG GCA CTG GGC GCC AAg TCT GGC ATC TCT GGC TTG

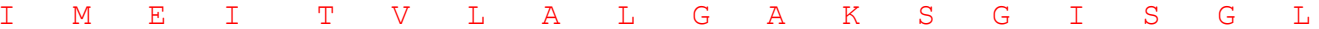
CGT GAA TTT TGC CTG CTG AGC GCC ATC TTG TTG GCC TAC GAT TTC ATC ATC ATG $\begin{array}{lllllllllllllllllllllllllll}R & E & F & C & L & L & S & A & I & L & L & A & Y & D & F & I & I & M\end{array}$ TTC ACT TGG TAC ACG GCA GTA TTG GCG TTA AAg TTG GAg TTG CTG AGA ATC CGC $\begin{array}{llllllllllllllllll} & \mathrm{T} & \mathrm{W} & \mathrm{Y} & \mathrm{T} & \mathrm{A} & \mathrm{V} & \mathrm{L} & \mathrm{A} & \mathrm{L} & \mathrm{K} & \mathrm{L} & \mathrm{E} & \mathrm{L} & \mathrm{L} & \mathrm{R} & \mathrm{I} & \mathrm{R}\end{array}$ GAA ATC AAC GGC ACA AGC AAC AAG TCT GCA AAG ACC ACT GGC ACA GGA TAC ATC $\begin{array}{llllllllllllllllll}E & I & N & G & T & S & N & K & S & A & K & T & T & G & T & G & Y & I\end{array}$ CGT AGC ACC GTC GTC AAG GCA TTC AGT GAT AGC ACA ACA ACA AAC AAC AGC TCC $\begin{array}{llllllllllllllllll}R & S & T & V & V & K & A & F & S & D & S & T & T & T & N & N & S & S\end{array}$ AGC ATC AAG ACG GAC GAG CCC ATC ATT GGC AGA GTG AAg CTC TTG ATG gtaagct

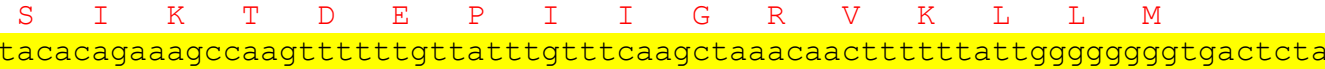

tag ATT GTT GGA TTT GTG GCC ATG CAG CTC TTC AAg GTG TGC ACT ACC TTC CAA $\begin{array}{cccccccccccccccccc} & \text { I } & V & G & \text { F } & V & \text { A } & \text { M } & Q & \text { L } & \text { F } & \text { K } & V & \text { C } & \text { T } & \text { T } & \text { F } & \text { Q } \\ \text { GGA } & \text { TCG } & \text { TCG } & \text { GGT } & \text { CCT } & \text { CAG } & \text { GTT } & \text { AGT } & \text { GTC } & \text { GTT } & \text { GAA } & \text { CCT } & \text { GGT } & \text { GTG } & \text { AAT } & \text { AAT } & \text { GTG } & \text { CTG }\end{array}$

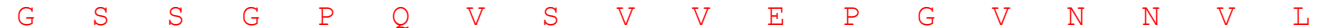
GAG AAG CTC CTT GAA CAG CAT CGT GCA TCC GAC ATG GGA CAC TTG CCT CTG TTG

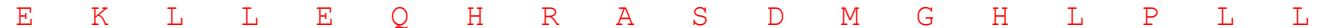
GTC GAA GTG TTT CCT CCT TTG CCC TTC CAC ATT GCA TCC TCC TCG TAC AAG GCC $\begin{array}{llllllllllllllllll}V & \mathrm{E} & \mathrm{V} & \mathrm{F} & \mathrm{P} & \mathrm{P} & \mathrm{L} & \mathrm{P} & \mathrm{F} & \mathrm{H} & \mathrm{I} & \mathrm{A} & \mathrm{S} & \mathrm{S} & \mathrm{S} & \mathrm{Y} & \mathrm{K} & \mathrm{A}\end{array}$ ATC GTT CCT GAC AGC ATC CGC CAG CCG TTG GAC TAT TTG CTC GAG ACA TAT GCC $\begin{array}{llllllllllllllllll}I & V & P & D & S & I & R & Q & P & L & D & Y & L & L & E & T & Y & A\end{array}$ GTC TAC ATT CAG CAT CCC GTC ATC TCC AAg TGg ATC ACA CTT GCT CTG TTT GTA $\begin{array}{llllllllllllllllll}V & Y & I & Q & H & P & V & I & S & K & W & I & T & L & A & L & F & V\end{array}$ TCC TTG TTC TTG AAC ACT TAC CTC TTC AAG GTA GCC AAG CAA CCC GCC AAG GCT $\begin{array}{llllllllllllllllllllllll}S & L & F & L & N & T & Y & L & F & K & V & A & K & Q & P & A & K & A\end{array}$ GCT CCT GCT GCT GCT GCC GAG ACC AAG AAA TCA ACA CCA ACA GTA GTA CCC ACC $\begin{array}{llllllllllllllllll}A & P & A & A & A & A & E & T & K & K & S & T & P & T & V & V & P & T\end{array}$ ATT ACC ACG GCT GAA AGA AAG ACA CAA CAC CAC CAC CAC CAC CAA AAG CAC AGC $\begin{array}{llllllllllllllllll}I & T & T & A & E & R & K & T & Q & H & H & H & H & H & Q & K & H & S\end{array}$ AGC AAA CAT TCC GCC GTT CAA GGC GTC ATt CGC ACA CTG GAA GAA TGC ATG CAA $\begin{array}{llllllllllllllllll}S & K & H & S & A & V & Q & G & V & I & R & T & L & E & E & C & M & Q\end{array}$ CTG ACA CAA ACA CCC GAA TCT CTG TCT GAC GAA GAA GTC ATC ATG CTA GTT CAA $\begin{array}{llllllllllllllllll}L & T & Q & T & P & E & S & L & S & D & E & E & V & I & M & L & V & Q\end{array}$ AAG GGC AAG ATG GCC TCC TAT GCG CTG GAA AAg GTG CTG GGC GAT TTG GAg CGT $\begin{array}{llllllllllllllllll}K & G & K & M & A & S & Y & A & L & E & K & V & L & G & D & L & E & R\end{array}$ GCT GTC AGT ATC CGT CGT GCC TTG GTC TCT CGT GCC TCC ATC ACA AAG ACA CTG $\begin{array}{lllllllllllllllllll}A & V & S & I & R & R & A & L & V & S & R & A & S & I & T & K & T & L\end{array}$ GAA TCC AGT CTG TTG CCT CTC CAC AAC TAC CAC TAT GAC AAG GTG ATG GGC GCC $\begin{array}{lllllllllllllllllllllllll}E & S & S & L & L & P & L & H & N & Y & H & Y & D & K & V & M & G & A\end{array}$ TGT TGC GAA AAC GTC ATT GGC TAC ATG CCT ATt CCT GTC GGT GTC GCT GGT CCC

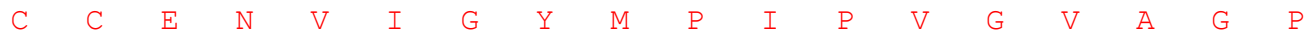
ATG AAC ATT GAC GGT GAC TCG ATT CAT ATC CCC ATG GCA ACC ACA GAA GGC TGT

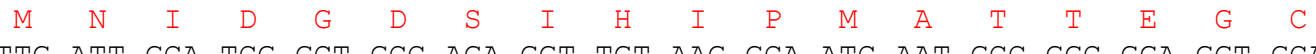
TTG ATT GCA TCG GCT GCC AGA GGT TGT AAg GCA ATC AAT GCC GGC GGA GGT GCA $\begin{array}{llllllllllllllllll}\mathrm{L} & \mathrm{I} & \mathrm{A} & \mathrm{S} & \mathrm{A} & \mathrm{A} & \mathrm{R} & \mathrm{G} & \mathrm{C} & \mathrm{K} & \mathrm{A} & \mathrm{I} & \mathrm{N} & \mathrm{A} & \mathrm{G} & \mathrm{G} & \mathrm{G} & \mathrm{A}\end{array}$ ACC ACG ATC ATt ACT GCT GAT GGC ATG ACC CGT GGC CCT TGT GTG GAA TTC CCT $\begin{array}{llllllllllllllllll}T & T & I & I & T & A & D & G & M & T & R & G & P & C & V & E & F & P\end{array}$ TCC ATC ATT GGC GCT GCT GCT TGC AAA AAG TTC ATT GAA GAA GAT GGC GCT GAA $\begin{array}{cccccccccccccccccc}\text { S } & \text { I } & \text { I } & \text { G } & \text { A } & \text { A } & \text { A } & \text { C } & \text { K } & \text { K } & \text { F } & \text { I } & \text { E } & \text { E } & \text { D } & \text { G } & \text { A } & \text { E } \\ \text { ATC } & \text { ATC } & \text { ACG } & \text { GCT } & \text { GCA } & \text { TTC } & \text { AAC } & \text { TCG } & \text { ACC } & \text { TCC } & \text { CGA } & \text { TTT } & \text { GCT } & \text { CGC } & \text { TTG } & \text { AGA } & \text { AAG } & \text { CTA }\end{array}$ $\begin{array}{llllllllllllllllll}I & I & T & A & A & F & N & S & T & S & R & F & A & R & L & R & K & L\end{array}$ AAG GTG GCT CTC GCC GGC AGA CTG GTC TTT ATC CGA TTC TCT ACC ACG ACC GGT $\begin{array}{llllllllllllllllll}\mathrm{K} & \mathrm{V} & \mathrm{A} & \mathrm{L} & \mathrm{A} & \mathrm{G} & \mathrm{R} & \mathrm{L} & \mathrm{V} & \mathrm{F} & \mathrm{I} & \mathrm{R} & \mathrm{F} & \mathrm{S} & \mathrm{T} & \mathrm{T} & \mathrm{T} & \mathrm{G}\end{array}$ 
GAC GCT ATG GGT ATG AAC ATG ATC tCC AAg GGC TGT GAA AAg GCA CTC Agt GTC

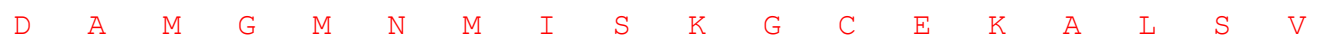
898

CTC TCT GAg CAT TTC CCT GAT ATG CAA ATC GTC TCC CTC TCT GGT AAT TAC TGT

ACT GAC AAg AAG CCT GCT GCT ATC AAT TGG ATC GAA GGC CGT GGT AAA TCC GTG

916 $\begin{array}{llllllllllllllllll}T & D & K & K & P & A & A & I & N & W & I & E & G & R & G & K & S & V\end{array}$

GTC GCT GAA GCC GTT ATT CCC GGG GCT GTC GTC GAG AAG GTT CTC AAG ACA ACT

934

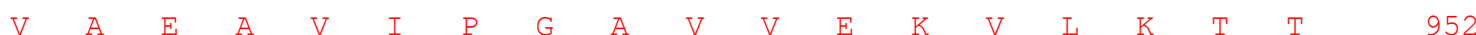

GTC GCT GCC TTG GTT GAA TTG AAT ATT tCT AAA AAC TTG ATC GGC TCT GCT ATG 3056

$\begin{array}{lllllllllllllllllll}V & A & A & L & V & E & \text { L } & \text { N } & \text { I } & \text { S } & \text { K } & \text { N } & \text { L } & \text { I } & \text { G } & \text { S } & \text { A } & \text { M } & 970\end{array}$

GCT GGT TCG GTT GGT GGT TTC AAT GCA CAT GCT GCC AAT ATC TTG ACA GCC GTG 3110

$\begin{array}{llllllllllllllllllll}A & G & S & V & G & G & F & N & A & H & A & A & N & I & \text { L } & \text { T } & \text { A } & \text { V } & & 988\end{array}$

TAT TTA GCC ACG GGC CAA GAT CCT GCT CAA AAC GTG GAA AGC TCA AAC TGT ATC 3164

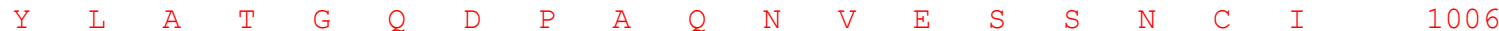

ACC TTG ATG AAg GCC ATC AAC AAC AAT CAA GAT TTG CAC ATT TCA TGT AGC ATG 3218

$\begin{array}{lllllllllllllllllll}T & \mathrm{~L} & \mathrm{M} & \mathrm{K} & \mathrm{A} & \mathrm{I} & \mathrm{N} & \mathrm{N} & \mathrm{N} & \mathrm{Q} & \mathrm{D} & \mathrm{L} & \mathrm{H} & \mathrm{I} & \mathrm{S} & \mathrm{C} & \mathrm{S} & \mathrm{M} & 1024\end{array}$

CCT AgC AtT GAA GTG GGC ACC ATT GGC GGT GGC ACC ATT TTG CCT CCT CAA CAA 3272

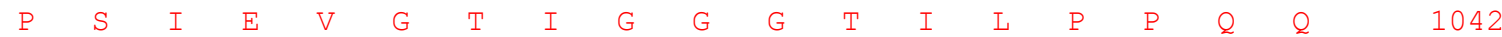

GCC ATG CTC GAC ATG CTC GGT GTT CGT GGT CCT CAT CCT ACT GAA CCA GGA AAg 3326

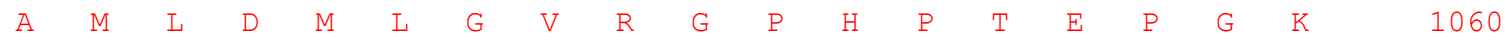

AAC GCT CAA AGA CTT GCC AGA ATC ATC TGT GCT GCT GTC ATG GCT GGC GAA CTG 3380

\begin{tabular}{lllllllllllllllllll}
$\mathrm{N}$ & $\mathrm{A}$ & $\mathrm{Q}$ & $\mathrm{R}$ & $\mathrm{L}$ & $\mathrm{A}$ & $\mathrm{R}$ & $\mathrm{I}$ & $\mathrm{I}$ & $\mathrm{C}$ & $\mathrm{A}$ & $\mathrm{A}$ & $\mathrm{V}$ & $\mathrm{M}$ & $\mathrm{A}$ & $\mathrm{G}$ & $\mathrm{E}$ & $\mathrm{L}$ & \\
\hline
\end{tabular}

TCT CTC TGT GCT GCC TTG GCT GCA GGT CAT TTA GTC AAG GCT CAT ATG GCT CAT 3434

\begin{tabular}{lllllllllllllllllll}
$\mathrm{S}$ & $\mathrm{L}$ & $\mathrm{C}$ & $\mathrm{A}$ & $\mathrm{A}$ & $\mathrm{L}$ & $\mathrm{A}$ & $\mathrm{A}$ & $\mathrm{G}$ & $\mathrm{H}$ & $\mathrm{L}$ & $\mathrm{V}$ & $\mathrm{K}$ & $\mathrm{A}$ & $\mathrm{H}$ & $\mathrm{M}$ & $\mathrm{A}$ & $\mathrm{H}$ & \\
\hline
\end{tabular}

AAC CGT GCT GCT GCT GCT GCT ACA CCA GCC GTT CCT GGA ACC TGC ATC AAA TCC 3488

$\begin{array}{lllllllllllllllllll}\mathrm{N} & \mathrm{R} & \mathrm{A} & \mathrm{A} & \mathrm{A} & \mathrm{A} & \mathrm{A} & \mathrm{T} & \mathrm{P} & \mathrm{A} & \mathrm{V} & \mathrm{P} & \mathrm{G} & \mathrm{T} & \mathrm{C} & \mathrm{I} & \mathrm{K} & \mathrm{S} & \\ 1114\end{array}$ TAA

3491 